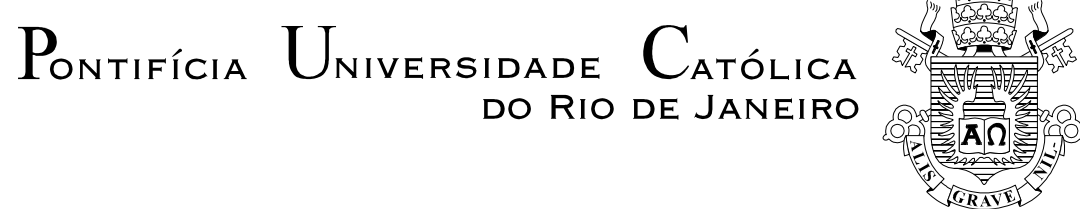

Anderson Rodrigues Teixeira

"O abiã é o começo, o pé da história": performances do noviciado no(s) candomblé(s)

Dissertação apresentada ao Programa de Pósgraduação em Ciências Sociais da PUC-Rio como requisito parcial para obtenção do grau de Mestre em Ciências Sociais.

Orientadora: Profa. Sonia Maria Giacomini

Rio de Janeiro

Março de 2017 


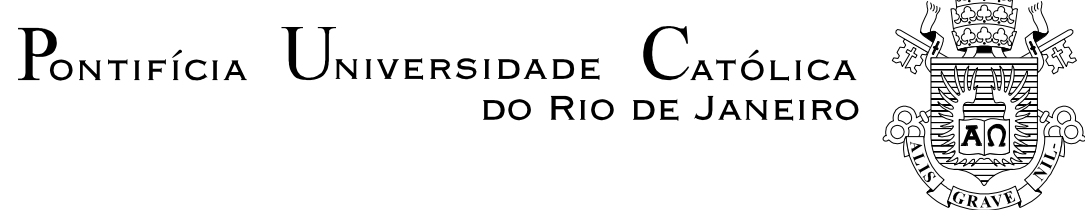

\title{
Anderson Rodrigues Teixeira
}

\begin{abstract}
"O abiã é o começo, o pé da história": performances do noviciado no(s) candomblé(s)

Dissertação apresentada como requisito parcial para obtenção do grau de Mestre pelo Programa de Pós-Graduação em Ciências Sociais do Departamento de Ciências Sociais do Centro de Ciências Sociais da PUC-Rio. Aprovada pela Comissão Examinadora abaixo assinada.
\end{abstract}

Profa. Sonia Maria Giacomini

Orientadora

Departamento de Ciências Sociais - PUC-Rio

Profa. Marcia de Vasconcelos Contins Gonçalves

UERJ

Prof. Valter Sinder

Departamento de Ciências Sociais - PUC-Rio

Profa. Mônica Herz

Coordenadora Setorial do Centro de Ciências Sociais - PUC-Rio 
Todos os direitos reservados. É proibida a reprodução total ou parcial do trabalho sem a autorização da universidade, do autor e da orientadora.

\section{Anderson Rodrigues Teixeira}

Graduou-se em Letras - Português e Literaturas de Língua Portuguesa (UNESA-RJ) em 2005 e Interpretação Cênica (UNESA-RJ) em 2000. Possui pósgraduação lato sensu em História e Cultura Afrodescendente (PUC-Rio/2013) e em Ciências da Religião (FSB-RJ/2014). Nos últimos dez anos atuou como coordenador pedagógico e docente de Língua Portuguesa e Inglesa em cursos, escolas e empresas no Rio de Janeiro. Como mestre em Ciências Sociais (PUCRio/2017) e pesquisador acadêmico, tem como principais áreas de interesse: antropologia, fenômeno religioso, religiões de matrizes africanas, performance, corporeidade e gênero. Dedica-se desde 2012 à pesquisa formal das modalidades de religiosidade de matrizes africanas no Brasil e sua interlocução com a contemporaneidade.

Ficha Catalográfica

\footnotetext{
Teixeira, Anderson Rodrigues

"O abiã é o começo, o pé da história" : performances do noviciado no(s) candomblé(s) / Anderson Rodrigues Teixeira ; orientadora: Sonia Maria Giacomini. - 2017.

198 f. : il. color. ; $29,7 \mathrm{~cm}$

Dissertação (mestrado) - Pontifícia Universidade Católica do Rio de Janeiro, Departamento de Ciências Sociais, 2017. Inclui bibliografia

1. Ciências Sociais - Teses. 2. Candomblé. 3. Noviciado. 4. Abiã. 5. Abianato. 6. Performance. I. Giacomini, Sonia Maria. II. Pontifícia Universidade Católica do Rio de Janeiro. Departamento de Ciências Sociais. III. Título.
} 


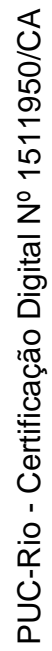

Com imenso amor,

À Vera Lucia, minha raiz.

Ao Marcio Azevedo, meu amado. 


\section{Agradecimentos}

À CAPES e à PUC-Rio, pelos auxílios concedidos, sem os quais este trabalho não poderia ter sido realizado.

À Sonia Maria Giacomini, que com sabedoria, generosidade e afeto, acolheu-me na PUC desde 2013. Serei eternamente grato pelos aprendizados e por ter acreditado em minhas inquietações intelectuais. Jamais esquecerei as "orientações", que servem para vida toda. Gratidão eterna!

Aos professores do Departamento de Ciências Sociais da PUC-Rio, pelos ensinamentos que a cada dia transformam meu olhar sobre a realidade.

Às secretárias do Departamento de Ciências Sociais da PUC-Rio, Ana Roxo e Mônica Gomes que desde meu primeiro contato com esta universidade me receberam com afeto e a maior presteza. Ao secretário Felipe Santos, que mesmo chegando depois, também buscou ajudar sempre que possível.

A todos os colegas discentes com os quais partilhei momentos de ricos aprendizados.

À Regiane Augusto de Mattos, professora do Departamento de História da PUCRio pelos ensinamentos e estímulos constantes nessa árdua trajetória acadêmica. Serei eternamente grato por cada incentivo e oportunidade de crescimento.

À professora Olívia Nogueira Hirsch, pelo estímulo e as valiosas ajudas desde a especialização em História e Cultura Afrodescendente, quando nos conhecemos na PUC-Rio no Departamento de Ciências Sociais.

À preciosa amiga Marina Helena Ramos pelo sopro estimulante que sempre leva minha embarcação a espaços longínquos de alegria e crescimento.

Ao amigo Marcio Righetti, pela generosa ajuda ao longo dessa pesquisa.

Ao querido amigo e "irmão de folha" Paulo Vitor, que acreditou e colaborou intensamente desde o início para a concretização deste sonho.

Às estimadas amigas Danielle de Souza, Fátima Cristina e Glauce Telles, pelas 
palavras fortificantes em todas as etapas dessa desafiadora trajetória pessoal e profissional. Minha eterna e afetuosa gratidão!

A todos os estimados amigos que de alguma maneira compreenderam minha longa ausência criadora. Muitos nomes precisariam ser ainda citados para ser mais justo, mas a restrição de espaço não me permite.

A todos os abiãs que escreveram comigo esta "história". Meu eterno agradecimento por partilharem suas tão delicadas experiências de abianato. Este texto etnográfico não "reproduz" metade de tudo que aprendi com vocês.

Aos líderes religiosos que me receberam em seus terreiros, compartilhando generosamente suas experiências no candomblé. Adupé!

À minha valiosa mãe Vera Lúcia, pela força e compreensão incondicional ao longo dessa caminhada que me exigiu variadas ausências.

Ao meu querido irmão Diego Rodrigues, por sempre acreditar e apoiar minhas escolhas.

Especialmente, ao meu amado Marcio Azevedo, que como ninguém mais, acompanhou "de dentro" os labirintos que esta pesquisa me levou a percorrer. Sua força, seu amor, e sua presença suave foram imprescindíveis neste meu rito de passagem acadêmico.

Adupé Olorum babá Olodumaré.

Adupé awon gbogbo arassalé.

Adupé babá mi Airá Ibõna.

Adupé babá mi Erinlé.

Adupé eledá mi Ajagunã. 


\section{Resumo}

Teixeira, Anderson Rodrigues; Giacomini, Sonia Maria. "O abia é o começo, o pé da história": performances do noviciado no(s) candomblé(s). Rio de Janeiro, 2017. 198p. Dissertação de Mestrado Departamento de Ciências Sociais, Pontifícia Universidade Católica do Rio de Janeiro.

Este estudo contribui para a compreensão do primeiro estágio hierárquico do candomblé, denominado: abianato. Enfatizando a categoria dos abiãs no processo iniciático desta modalidade religiosa afro-brasileira, são reveladas as percepções dos próprios noviços sobre a experiência do abianato. Tendo em vista o caráter "espetacular" das cerimônias públicas do candomblé, as performances dos abiãs são analisadas segundo a perspectiva da antropologia da performance, proposta por Richard Schechner. Nesta pesquisa, o período do abianato não é percebido apenas como uma participação meramente sociológica do religioso. Ao contrário, constitui-se como uma etapa ritual fundamental na construção identitária do candomblecista.

\section{Palavras-chave}

Candomblé; noviciado; abiã; abianato; performance. 


\section{Abstract}

Teixeira, Anderson Rodrigues; Giacomini, Sônia Maria (Advisor). "The abia is the beginning, the foot of the story": performances of the novitiate at candomblé(s). Rio de Janeiro, 2017. 198p. Dissertação de Mestrado - Departamento de Ciências Sociais, Pontifícia Universidade Católica do Rio de Janeiro.

This study contributes to the understanding of the first hierarchical stage of candomblé, denominated: abianato. Emphasizing the category of abiãs in the initiation process of this Afro-Brazilian religious modality, the novices themselves perceptions of the experience of abianato are revealed. In view of the "spectacular" character of candomblé public ceremonies, the performances of the abiãs are analyzed according to the perspective of performance anthropology, proposed by Richard Schechner. In this research, the period of the abianato is not perceived only as a merely sociological participation of the religious. On the contrary, it constitutes a fundamental ritual stage in the identity building of the candomblecista.

\section{Keywords}

Candomblé; novitiate; abiã; abianato; performance. 


\section{Sumário}

1. Os "pés" da história sobre abiãs 11

2. "Cada casa é uma casa, cada cabeça uma sentença": 22 encontrando cenários e performers

2.1. Abiãs - A escalação do "elenco" de performers 29

2.2. A mise em scène de mãe Dora 57

2.3. A mise em scène de pai Carlito 60

3. "O encanto começa quando vê a festa": "espetáculo" e 65 performance nos candomblés

3.1. "É lindo! É bonito! É fantasia! É aquela coisa bonita de 72

se ver!" - Candomblé para crer, ver e ter prazer

3.2. "Parece um carnaval assim meio fechado":

77

Descortinando o "espetáculo" dos orixás

3.3. "Senti meu coração bater muito forte. Quero ficar aqui!":

93

da "plateia" ao "palco" na dança dos orixás

4. "A gente é a chave de entrada para a religião": Abianato e

109 performance ritual nos candomblés

4.1. "O abiã é o começo, o pé da história" - O corpo e suas metáforas nos candomblés

4.2. To be or not to be - Entendendo o papel de abiã

4.3. "Orixá não nasce sabendo dançar" - Liminaridade e restauração do comportamento nos candomblés

4.3.1. Raspado, catulado e adoxado - A construção da performance do rum

4.3.2. Abiã vira no santo? - A performance do bolar ou "passar mal"

5. A "feitura" do antropólogo: O cerrar das cortinas

6. Referências bibliográficas 
[...] fazer uma experiência com algo significa que algo nos acontece, nos alcança; que se apodera de nós, que nos tomba e nos transforma. Quando falamos em "fazer" significa aqui: sofrer, padecer, tomar o que nos alcança receptivamente, aceitar à medida que nos submetemos a algo. Fazer uma experiência quer dizer, portanto, deixar-nos abordar em nós próprios pelo que nos interpela, entrando e submetendo-nos a isso. Podemos ser assim transformados por tais experiências, de um dia para o outro ou no transcurso do tempo.

Martin Heidegger, A caminho da linguagem ${ }^{1}$

[...] eu vô "fazê o santo". Eu quero vê... são experiências novas! A gente sonha... quer tê experiências! Só vou saber isso quando eu tê a minha experiência... podê falá assim... "sou o Afonso Camargo"... se eu for raspado de Ogum... "sou filho de Ogum!" E contá futuramente como foi, né? No meu futuro... podê olhá o DVD depois. "Gente, foi assim... assim". Muito emocionante!

abiã Afonsinho

${ }^{1}$ Apud. Jorge Larrosa (2004) 


\section{Os "pés" da história sobre abiãs}

[...] Acredito que você foi bem específico nos seus questionamentos. Parece que o abiã ele é só... que realmente não existe uma importância. Essa importância que você tá dando. Não tô falando do meu terreiro agora... de modo geral, não existe! Mas se você fô pará pra analisá, em determinados momentos dentro do axé às vezes você tem dez iaôs e dois abiãs. Mas os abiãs tão valendo mais do que o iâ̂ ali, ou que o ebôme! (abiã Vanise)

Valendo-me da metáfora apresentada por um de meus interlocutores ao longo do percurso etnográfico (cf. Silva, 2009), digo que o "pé” da história como pesquisador formal a respeito das religiões de matrizes africanas no Brasil, foi justamente quando meus pés estavam submersos na vivência religiosa do terreiro ${ }^{2}$ de candomble $^{3}$, no qual fui iniciado ${ }^{4}$ em 2008 para a religião dos orixás.

Livre do peso que por muitas décadas recaiu sobre os ombros de diversos antropólogos, tenho o privilégio de iniciar esta escrita acadêmica com a liberdade de expor sem embaraços este dado tão pessoal e ao mesmo tempo tão relevante nesta empreitada intelectual. Penso que, mais do que ter me fornecido um objeto de pesquisa, todos os meus passos dentro do universo rico e complexo das religiões de matrizes africanas produzem influências inegáveis na maneira como agora visto as lentes do antropólogo, para experienciar a realidade do povo-desanto $^{5}$ (cf. Amaral, 2002; Lody, 2006) exercitando certo estranhamento neste

2 Terreiro: expressão nativa para designar o templo litúrgico do candomblé. Possui diversos correlatos como: casa de santo; casa de axé (ou simplesmente axé); roça; roça de santo; barracão; ilê axé etc. Em certos momentos percebe-se o uso do termo candomblé como referência também ao espaço físico no qual a religião é praticada.

${ }^{3}$ Candomblé: modalidade religiosa de matrizes africanas praticada em diversas partes do Brasil. Caracterizada de modo geral pelo culto das divindades disseminadas na diáspora africana (orixás, voduns e inquices). O culto está organizado internamente segundo uma noção nativa de nações étnicas de origem. Esta classificação implica no uso de vocabulário e ritualística própria para cada uma delas. $\mathrm{O}$ chamado terreiro ou casa de axé caracteriza sua cede principal de prática ritual. No entanto, no Rio de Janeiro, diversos templos afro-brasileiros apresentam práticas híbridas de candomblé e outras pertenças religiosas, conforme indicado por Fonseca \& Giacomini (2013).

${ }^{4} \mathrm{~A}$ iniciação religiosa ao candomblé é constituída por um rito de passagem denominado feitura, que inclui uma prolongada reclusão ritual estruturada sobre rígidas regras de comportamento e interdições rituais. É apenas passando por este processo formal, que o adepto poderá considerarse um membro oficial ou efetivo. No desenvolvimento da dissertação este processo será descrito em maiores detalhes.

${ }^{5}$ Povo-de-santo: refere-se à complexa diversidade de adeptos das religiões de matrizes africanas no Brasil. 
"labirinto de conflitos dramáticos" (DaMatta, 1978, p. 30), o qual o ofício antropológico me lançou. Assim, para além de todo o exercício constante de "distanciamento" crítico, mesmo em alguma instância nem sempre perceptível, os ecos desta pertença primeva irão refletir no rumo e na qualidade deste meu artesanato intelectual, já que configura-se como o centro de mim mesmo e estarei sempre pessoalmente envolvido nesta produção (cf. Mills, 2009).

Acreditando que o "trabalhador intelectual forma-se a si próprio à medida que trabalha para o aperfeiçoamento de seu ofício" (Idem, 2009, p. 22), ponho em revisão sucinta um trecho desta minha biografia, marcada pela chegada da brisa inquietante do anthropological blues em minha trajetória (cf. DaMatta, 1978).

No ano de 2012 - já tendo passado pelo noviciado e consecutiva iniciação no candomblé - tive a rica e desafiante oportunidade de desenvolver um projeto de educação não formal dentro da minha comunidade litúrgica, a pedido de meu sacerdote, para que eu conciliasse minha habilidade profissional de professor com as atribuições religiosas que me cabiam na circunstância. As "aulas" elaboradas por mim nos encontros semanais visavam, sobretudo, uma introdução não apenas aos aspectos religiosos, mas também ao contexto histórico e cultural de formação das religiões de matrizes africanas no Brasil. À parte as implicações pessoais e religiosas que esta experiência me gerou, este foi o primeiro passo para uma maior aproximação das Ciências Sociais e do estudo acadêmico desta temática, já que minha formação original havia sido em Letras e Interpretação Teatral. Portanto, foi o ensejo desta prática educativa informal no terreiro, que me levou de volta à academia.

Munido do desejo inicial de compreender melhor a história e a cultura afro-brasileira em seu sentido amplo, iniciei o curso de pós-graduação lato sensu em História e Cultura Afrodescendente na PUC-RJ (2012). No decorrer dos semestres, o contato com a literatura socioantropológica despertou um profundo interesse pela abordagem das Ciências Sociais a respeito dos fenômenos culturais, e especificamente, do fenômeno religioso afro-brasileiro. Então, ao término do curso, produzi uma monografia investigando as motivações de novos adeptos de alguns candomblés no Rio de Janeiro. Para este exercício intelectual, iniciei uma produção etnográfica a partir de entrevistas e observação participante em diferentes terreiros do estado. Devido às limitações de tempo desta especialização, não foi possível analisar todo o material adquirido, assim como, 
responder todas as questões suscitadas pela pesquisa. Tive desta forma um excelente pretexto para a continuidade do exercício de pesquisador.

Em 2014, ávido por aprofundar este estudo e dar continuidade a minha trajetória acadêmica, ingressei em outra pós-graduação lato sensu, desta vez, em Ciências da Religião (FSB/RJ). Cônscio do meu interesse pela cultura afrobrasileira e o fenômeno religioso nas sociedades, procurei sistematizar ainda mais meus estudos a respeito dessas áreas temáticas. Sendo um curso multidisciplinar, encontrei-me novamente com a antropologia e a sociologia, no debate sobre as diversas formas de religiosidade que as culturas humanas são capazes de engendrar. Como objeto de pesquisa para a conclusão desta segunda especialização, decidi debruçar-me num estudo do terreiro enquanto território simbólico e de socialização para o povo-de-santo. Na ocasião, analisei brevemente a arquitetura e respectiva simbologia dos templos. Utilizando a bibliografia disponível para o assunto, aliada às incursões etnográficas que venho realizando desde então, finalizei nova monografia sobre as casas de axé.

Entrementes, a inquietação intelectual persistia e o desejo de estreitar minha relação com as Ciências Sociais só aumentava. Acreditava que o estudo iniciado em 2013, a respeito dos noviços em candomblés do Rio de Janeiro, ainda poderia ser melhor aprofundado. Para tanto, ingressei em 2015 no curso de mestrado do Programa de Pós-Graduação em Ciências Sociais (PUC-RJ), retomando as reflexões sobre ritual e ritos de passagem em alguns candomblés do Rio de Janeiro contemporâneo.

No que concerne propriamente ao meu objeto de pesquisa inicial (2013), minha inquietação era a respeito das motivações e expectativas que orientam certos indivíduos na atualidade a se inserirem no complexo contexto ritual dos candomblés. Conhecendo "de perto" e "de dentro" (cf. Magnani, 2012) os valores que norteiam o ethos do povo-de-santo (cf. Amaral, 2002), interrogava-me sobre as motivações possíveis que poderiam levar sujeitos de uma realidade social tão individualista e de relações cada vez mais virtualizadas a se lançarem numa prática cultural tão marcada por outro tipo de relação com o corpo e as formas de socialização. A adesão desses sujeitos modernos a uma estrutura tão hierarquizada a partir de uma noção de "tradição" me instigava sobremaneira. Em linhas gerais, foi através desta questão central que passei a perseguir na literatura especializada sobre candomblé as representações dos anseios desses indivíduos. O que muito 
me surpreendeu, como demonstrarei posteriormente. Paralelo a isso, retomei imediatamente meu percurso etnográfico buscando dar sustância às ideias que emergiam do mergulho bibliográfico sobre o tema.

Contudo, antes de prosseguir com os desdobramentos que delinearam a questão central desta pesquisa atual, é fundamental expor algumas noções específicas que propiciarão um entendimento mais límpido do estudo aqui proposto.

Primeiramente, é necessário destacar e explicar uma categoria nativa com a qual venho trabalhando desde então: o abiã. Mesmo sendo um termo bastante utilizado pelo povo-de-santo, não se configura como expressão "familiar" para aqueles que não estão inseridos neste universo cultural. Ao contrário de alguns termos como terreiro e orixá que foram bastante disseminados na cultura brasileira mais ampla. Da mesma maneira, como pude constatar surpreso, nem mesmo a literatura socioantropológica parece ter dado tratamento atencioso a esta categoria nativa. Como pode ser facilmente percebido nesta introdução, até agora tenho utilizado apenas a categoria sociológica noviço, para referir-me ao sujeito central deste estudo. Dito isto, considero mais que oportuno introduzir e explicar a categoria que, não apenas dá título a esta produção acadêmica, mas constitui a pedra angular da mesma.

À guisa de introdução, direi que existem três categorias classificatórias dos religiosos dentro do candomblé, a partir do critério de condição iniciática: o abiã (abíyán), o iâo (ìyàwó) e o ebôme (ègbón: o mais velho; por extensão, ègbón mi: meu mais velho). Essas três categorias podem servir como identificação de qualquer fiel independentemente de seu gênero, contando apenas a condição de ser iniciado e a respectiva idade iniciática. Vale sempre lembrar que, o princípio de senioridade atravessa toda a estrutura e o funcionamento desta religião, constituindo-se como critério imprescindível para organizar qualquer atividade desempenhada por seus adeptos, conforme enfatiza Reginaldo Prandi (1996; 2001).

Os primeiros desta escala classificatória - os abiãs - constituem os postulantes ao rito de passagem denominado como feitura ${ }^{6}$. Mas cabe destacar

\footnotetext{
6 Feitura: expressão local para identificar a iniciação do neófito no candomblé. Há diversos correlatos deste termo no uso cotidiano dos religiosos, tais como: "fazer santo", "fazer cabeça", "raspar santo", "raspar cabeça", "deitar para o santo", "dar obrigação" (de santo) etc. Nota-se a
} 
também que, mesmo na condição de pré-iniciandos, os abiãs já fazem parte de um grupo religioso específico, com o qual estabelecem laços morais incipientes. Em seguida, a segunda categoria é constituída por aqueles que já vivenciaram a feitura e num período de sete anos, serão reconhecidos como tais, ou seja, ainda no status de iâ̂. No decorrer desse período, embora possam ser realizadas cerimônias que atualizam sua legitimidade iniciática, estas não alterarão seu status de iaô. Após esta jornada de vivência e aprendizado, dá-se um novo rito de passagem, comumente chamado de recebimento do decá ${ }^{7}$. Este último, outorga ao religioso o novo e definitivo status de ebôme, ou seja, um membro mais velho da comunidade litúrgica. Além do que, nesta circunstância especial, alguns dos adeptos recebem da liderança religiosa, a autorização pública para exercerem a função sacerdotal, conforme o histórico espiritual do indivíduo determinar na ocasião.

Isto posto, reafirmo que a preocupação nuclear deste estudo apoia-se na investigação da presença e atuação dos abiãs no contexto ritual e social do candomblé. No decurso de minhas pesquisas, pude observar estupefato que, desde os primeiros registros socioantropológicos a respeito do candomblé, podemos verificar se não a ausência completa do registro de sua presença, ao menos, citações por demais breves que não valorizam satisfatoriamente o papel representado por estes religiosos nos terreiros.

Em muitos dos casos, a literatura acaba por reforçar a impressão de que o ponto de partida da carreira sacerdotal está fixado na feitura do iâo, desconsiderando assim o período de abianato $^{8}$ como parcela desta iniciação processual. Vale lembrar que um indivíduo pode permanecer abiã por um curto,

forte condição sincrética desta religião no Brasil, onde as divindades africanas (orixás, voduns e inquices) foram correlacionadas aos santos católicos por um longo tempo. Maiores informações ver: Silva (1995; 2005b).

7 Decá, conforme explica Olga G. Cacciatore (1977) é um termo de origem iorubá no qual "dé" significa chegou/alcançou e "ká" estudou/decifrou. Para maiores informações sobre a relação desta espécie de título litúrgico no candomblé e sua relação simbólica com o diploma universitário ocidental, ver a discussão de Luciana Duccini (2016).

8 Utilizarei o termo abianato para me referir ao período em que os religiosos estão no status de abiãs. Acredito que o uso do termo antropológico noviciado, neste estudo, não seria tão aclarador, já que em boa parte da literatura especializada ele tem se referido à fase posterior do ciclo iniciático, ou seja, o status do iaô durante a feitura. Muitos autores utilizam a categoria noviço para indicar apenas o momento em que o fiel está recluso no ritual de iniciação. Nesta pesquisa, busco justamente reforçar a ideia de que o noviciado engloba todo o período anterior à reclusão iniciática, ou seja, toda a experiência do fiel como abiã (o abianato). 
longo ou indeterminado período de tempo. Sendo assim, no momento do rito iniciático (a reclusão para a feitura), este mesmo indivíduo já poderá ter desfrutado de uma intensa vivência de aprendizados no seu terreiro.

Ademais, estando presente no dia a dia de algumas casas de axé do Rio de Janeiro, conscientizei-me também do papel fundamental destes abiãs para a manutenção da religião. A existência da chamada reserva de abiãs assegura não apenas que novos indivíduos possam ser iniciados, para que substituam os mais velhos e possibilitem a perpetuação do culto, como, além disso, indicam sinal de prestígio para os líderes religiosos e seus respectivos templos. O que constitui uma preocupação constante dos pais e mães-de-santo ${ }^{9}$ que precisam captar abiãs para transformá-los em iaôs e terem projetado nestes neófitos a demonstração de seu "prestígio e habilidade ritual" (cf. Vogel, 2005; Opipari, 2009).

Todavia, revisitando algumas obras consideradas clássicas nos estudos do candomblé (Rodrigues, 1935; Pierson, 1942; Herskovits, 1943; Bastide, 1971; 1973; 2001; Landes, 1977; 2002; Carneiro, 1991, 2008; Santos, 2002; Verger, 2002a, 2002b, 2012; Querino, 2010 $)^{10}$ podemos observar que a menção ao abiã , quando realizada, restringe-se na maior parte das vezes a tentativa de "traduzir" o sentido deste terno nativo, sem investigar com algum grau de refinamento a sua atuação em si nas redes de sociabilidade de determinados terreiros.

Em certas obras, o termo abiã é citado unicamente como uma nota explicativa ao pé da página ou compondo um glossário da terminologia ritual afro-brasileira, no qual o termo frequentemente é um dos primeiros. Nestes estudos, o abiã parece ser retratado apenas enquanto um tipo ideal weberiano, mas que não adquire a mesma concretude dispensada às outras categorias de atores sociais que compõem este contexto religioso, como os sacerdotes e as pessoas já "feitas".

Mesmo Pierre Verger (2012) ${ }^{11}$ que investe algum tempo ao descrever os ritos propiciatórios da lavagem de $\operatorname{contas}^{12}$ e do bori $^{13}$ - rituais que algumas vezes

\footnotetext{
${ }^{9}$ Expressão afetuosa para se referir às lideranças no candomblé. Pode ocorrer também o uso do termo zelador de santo.

${ }^{10}$ As datas entre parênteses são referentes às edições que possuo das obras.

${ }^{11}$ A obra "Notas sobre o culto aos orixás e voduns" teve sua publicação original no Senegal em 1957. A primeira edição brasileira é de 1999.

${ }^{12}$ A lavagem de contas é um rito propiciatório no qual o indivíduo que se torna abiã recebe um colar ritual simples, consagrado pelo sacerdote nesta ocasião. A aquisição deste colar ritual - o
} 
demarcam o início formal do abianato - não deixa de ratificar a mesma indiferença pelo tema do abianato, há tanto tempo refletida na literatura especializada sobre o candomblé.

Além do mais, nestes e tantos outros estudos, esta lacuna se alarga bastante se formos considerar a possibilidade destes abiãs aparecerem representados por suas próprias narrativas. Por outro lado, no tocante a esta consideração, podemos destacar algumas etnografias mais contemporâneas (Prandi, 1991; Barbara, 2002; Opipari, 2009) que apontam uma incursão nesta direção, ainda que incipiente. Nestes casos, encontramos não apenas o reconhecimento do status do abiã como a base da (re)construção identitária do religioso candomblecista, como também é possível perceber - mesmo num curto fôlego - o próprio discurso destes atores no tocante às suas experiências de abianato.

Embora o abianato não seja o cerne de sua tese, a antropóloga Carmem Opipari (2009), não apenas percebe a presença e relevância dos abiãs em terreiros de São Paulo, como dedica parte de um subcapítulo para tratar da questão. Em sua atenta e cuidadosa abordagem, a autora procura enfatizar no debate a respeito da hierarquia, o papel desses abiãs como etapa primária da socialização e do aprendizado na carreira religiosa dos adeptos. Além de trazer uma pequena amostra do pensamento desses atores sociais na trama intrincada das relações no terreiro, ela identifica algumas mudanças ocorridas na forma de experienciar o abianato nos candomblés que pesquisou.

Com a mesma perspicácia, Reginaldo Prandi (1991) e Rosamaria Barbara (2002), ao contrário do que comumente acontece nos estudos do candomblé, elaboram suas análises sobre o processo iniciático dos neófitos fitando com atenção as ocorrências do abianato, fornecendo-nos uma importante contribuição no estudo deste aspecto do candomblé até então pouco estudado.

Então, no rastro das constatações supracitadas, parti em busca de uma aproximação cada vez maior destes abiãs. Deixei-me guiar pela tentativa de compreender melhor suas atuações e autorreflexões nas interações face a face (cf. Goffman, 2014) que estão submetidos neste período de integração a um grupo

fio-de-contas - é símbolo da proteção dos orixás e do laço moral incipiente do abiã com a comunidade litúrgica.

13 Bori: cerimônia litúrgica de fortificação energética da cabeça (orî) de um fiel. Caracteriza-se pelo oferecimento de diversas oferendas ao orí, que, no candomblé, é tido como uma divindade a ser cultuada no corpo de um adepto em primeiro lugar. 
religioso.

Ao observar a atuação dos abiãs e descortinar suas trajetórias, fui percebendo o quanto sua adesão (ou não) ao candomblé estava imbricada com o impacto que a dimensão "espetacular" do culto exerce sobre seus frequentadores. Os papeis representados (cf. Goffman, 2014) pelos abiãs no contexto religioso, ao regularem suas condutas nas interações rituais, aguçaram minha percepção para o caráter performático dessas relações. Por esta razão, comecei a pensar o período do abianato como uma etapa preliminar da performance ritual dos religiosos "feitos".

A percepção da dimensão "teatral” das cerimônias públicas do candomblé (cf. Santos, 2005; Amaral, 1998, 2002) e as algumas performances discursivas sobre o abianato, me fizeram detectar a existência real deste continuum entre ritual e teatro, como proposto por Richard Schechner (1988; 2003; 2011; 2012a; 2012b).

$\mathrm{Na}$ medida em que a vivência do filho-de-santo ${ }^{14}$ no candomblé coaduna uma "experiência de socialização, de fé e de prazer estético" (Idem, 2003; 2012a; 2012b), podemos identificá-la como uma performance. Como o próprio Schechner $(2003 ; 2012 \mathrm{a} ; 2012 \mathrm{~b})$ enfatiza diversas vezes, "separar arte e ritual é particularmente difícil", pois a performance ritual concentra eficácia e entretenimento concomitantemente.

Sendo assim, buscarei interpretar o abianato enquanto performance ritual em paulatina construção. Por este prisma, o período como abiã está para a performance do religioso "feito", assim como o ensaio está para o espetáculo pronto. Exemplo similar é dado por Schechner ao dizer que "o longo período da infância e da adolescência característico da espécie humana consiste em um extenso período de treinamento e ensaio para favorecer uma boa performance na vida adulta" (Idem, 2003, p. 27).

Seguindo a teorização de Schechner sobre os estudos da performance, procuro demonstrar nesta pesquisa, que a vivência do indivíduo como abiã

${ }^{14}$ Filho ou filha-de-santo: segundo as regras de parentesco ritual do candomblé, a expressão designa aquele submetido à maternidade ou paternidade ritual da mãe ou do pai-de-santo. Por extensão temos: irmãos-de-santo, avós-de-santo, tios-de-santo etc. Nota-se no termo a conotação sincrética elabora no Brasil entre santos católicos e divindades africanas. Porém, seu uso difundido não implica obrigatoriamente uma prática sincrética nas cerimônias rituais. Para maior detalhamento, ver: Lima (2003). 
constitui-se num "laboratório", onde paulatinamente sua nova identidade é construída e treinada, visando sua performance ritual autorizada após a feitura. $\mathrm{O}$ período do noviciado, ao contrário do que farta literatura deixou subentender, caracteriza-se não apenas como uma participação estanque do ritual iniciático formal, ou seja, o momento da feitura. Mas ao contrário, porque o termo participação no contexto do candomblé não deve ser "reduzido pela análise ao seu sentido sociológico quando sabemos que, de fato, ele também pode ser entendido em uma acepção propriamente ritual" (Goldman, 2012, p. 277).

Contudo, não se tratando aqui de um estudo da casa de santo, mas da experiência específica de uma categoria existente em seu interior, tenho como base empírica das reflexões que apresentarei a observação participante, as conversas informais e as entrevistas realizadas com um grupo de doze abiãs de diferentes terreiros de candomblé em distintas regiões do Rio de Janeiro.

No entanto, pela permanente oscilação da reserva de abiãs nos terreiros e as dificuldades comuns do trabalho etnográfico em conciliação com a disponibilidade de um pesquisador no curso de mestrado, escolhi como referência mais sistematizada, dois terreiros da zona oeste da cidade. Essa escolha se deu não apenas pelo acesso mais favorável que consegui, mas por vislumbrar também a riqueza que a confrontação destes dois casos pode proporcionar em alguns momentos do estudo.

Foram os terreiros da mãe-de-santo Dora e do pai-de-santo Carlito identificados por pseudônimos, assim como todos os participantes da pesquisa que me permitiram uma maior aproximação de suas rotinas religiosas, para além das cerimônias públicas festivas do culto. Porém, insisto no fato de que este não constitui um estudo do templo litúrgico.

Nos últimos quatro anos, frequentei e entrevistei mais templos e religiosos do que a necessidade de delimitação me exigiu para a finalização deste projeto. Todavia, isto não significa que passagens do meu percurso etnográfico não formalizadas não serão apropriadas como enriquecedoras contribuições para este estudo do abiã. Consciente de que o "etnógrafo é um redator, um editor, um revisor, um copy desk" (Silva, 2009, p. 183), até mesmo um primeiro contato de apresentação a um terreiro que não se desdobrou em entrevistas e/ou subsequentes visitas, poderá contribuir com a lembrança de um gesto, uma fala, um simples distanciamento, enfim, uma performance. $\mathrm{O}$ que é sempre bem vindo à prática do 
etnógrafo com seu texto, pois esta "se desenvolve distendendo múltiplas linhas de performances das quais ele próprio é o regente" (Silva, 2009, p. 183).

No tocante ao resultado textual desta bricolagem intelectual (cf. Peirano, 2014) que constitui este exercício etnográfico, de "colocar no texto - em palavras sequenciais, em frases que se seguem umas às outras, em parágrafos e capítulos o que foi ação vivida" (Idem, 2014, p. 386), tentei dar uma "arrumação" (cf. Silva, 2009) possível em três partes principais.

No capítulo dois, apresentarei os participantes deste estudo procurando contextualizar as entrevistas semiestruturadas que realizei. Ao longo desta sessão darei ênfase às partes mais relevantes das trajetórias dos religiosos até o ingresso no candomblé. O maior destaque será dado aos discursos dos abiãs, já que suas vivências do abianato constituem o foco da reflexão ora proposta.

No capítulo três abordarei a dimensão "espetacular" e performática das cerimônias públicas do candomblé, destacando-a como um fator de grande influência na adesão dos indivíduos a esta modalidade religiosa. A partir da noção de performance proposta por Richard Schechner, demonstrarei como a performance ritual apresenta uma profunda imbricação entre eficácia e entretenimento no contexto do candomblé. Irei retratar também a própria percepção dos fiéis a respeito desta dimensão "teatral” da religião, demonstrando a polissemia do uso que os próprios religiosos fazem desta noção.

No capítulo quatro, explicarei com maior ênfase o papel do abiã durante o abianato no contexto hierárquico da religião, dando ênfase às percepções que os próprios fiéis possuem a respeito desta experiência. Demonstrarei também como as performances rituais dos abiãs nas festividades religiosas podem ser interpretadas a partir da noção de comportamento restaurado ou comportamento duplamente exercido (cf. Schechner, 2003, 2011, 2012 a, b). Para tanto, analisarei duas modalidades performáticas que ocorrem nas festas dos orixás, que identifico como: a performance do bolar ou "passar mal" e a performance do rum. Levando em consideração a proposição de Schechner a respeito da performance como um momento de liminaridade vivido pelos performers, analisarei as semelhanças destes processos nas experiências de transe de orixá vividas nos terreiros por abiãs e filhos-de-santo já iniciados.

Enfim, tentarei esclarecer como este período do abianato já pode ser entendido como uma etapa ritual no panorama da construção processual da 
performance do candomblecista iniciado, procurando desfazer a ideia simplificadora de que este primeiro status da religião constitui apenas uma etapa de participação exclusivamente sociológica. 


\title{
"Cada casa é uma casa, cada cabeça uma sentença": encontrando cenários e performers
}

\begin{abstract}
Portanto, ter participado da religião antes de pesquisá-la, apresenta a vantagem de saber como se inserir e trafegar pelos terreiros, relacionar-se com seus membros e ler as entrelinhas de seus discursos, sendo uma 'ferramenta' útil para abrir algumas portas e facilitar a observação participante, embora essa vantagem não elimine certas dificuldades ou mesmo coloque outras (Vagner Gonçalves: 2006: 71).
\end{abstract}

Minha incursão formal nos estudos das religiões de matrizes africanas, assim como na prática do trabalho etnográfico, teve início propriamente no segundo semestre de 2013. Num antigo caderno que agora revisito em busca de reconstruir as memórias dessa trajetória pessoal e intelectual, em meio a uma profusão de notas e pequenos pedaços de papel que registram dicas de livros e filmes ou contatos de pessoas, consigo relembrar dados e emoções que permearam a construção deste projeto. No tal caderno, que na época servia apenas como um bloco de notas, vejo o esboço de como comecei a exercitar o uso da lente antropológica. Estas pistas deflagram minha feitura na antropologia.

Na página datada de 27 de agosto de 2013, encontro os vestígios da primeira reunião de orientação para a realização de minha monografia na especialização em História e Cultura Afrodescendente (PUC-RJ), onde o candomblé para além de ser uma pertença religiosa em minha vida, tornou-se um tema de pesquisa acadêmica.

No que posteriormente tornou-se meu caderno de campo, vejo anotadas em letras corridas as primeiras dicas de minha orientadora ao introduzirme num léxico profissional completamente novo para mim: entrevista piloto, perguntas abertas, caderno de campo etc. Saí daquela pequena saleta repleto de ideias, entusiasmo e expectativas, assim como um abiã em seu início.

Imediatamente, comecei a realizar o levantamento bibliográfico das inúmeras dicas dadas por minha orientadora e, já tomado pelo espírito inquieto e curioso de pesquisador, comecei a escarafunchar todo tipo de material possível para a realização de minha pesquisa. Não tinha consciência na época, mas a porta daquela pequenina sala havia aberto diante de mim as janelas para a imensidão do mundo, e como num "feitiço antropológico", fui capturado pelas "palavras 
mágicas" de minha "iniciadora". Hoje entendo que, mais do que ensinar antropologia, esta "pitonisa" propiciava e propicia minha feitura como antropólogo, entendendo o que Geertz (2001) nos ensina ao dizer que "a soberania do conhecido empobrece a todos" (Idem, 2001, p. 81) e, portanto, "devemos conhecer uns aos outros e viver com esse conhecimento, ou terminar isolados, num mundo beckettiano de solilóquios em choque" (Idem, 2001, p. 82).

Então, na inocência do desconhecimento da magia do antropólogo (cf. Silva, 2006), pensava que seria bastante tranquila a realização da empreitada intelectual, já que tinha uma excelente orientadora e possuía um conhecimento considerável do candomblé e do povo-de-santo. Mas não tardou para que eu logo descobrisse a profunda diferença entre ser "nativo" e estar "nativo/etnógrafo" (cf. Peirano, 2014). Desconhecia por completo esta experiência e seus imponderáveis efeitos colaterais.

Desta forma, imbuído de meu instinto etnográfico (Idem, 2014), vi-me diante do primeiro desafio: estabelecer contato com possíveis interlocutores. Neste exato momento, tive a consciência de como minha imersão no universo do candomblé até então poderia estar prestes a ser profundamente transformada. A partir dali, não apenas meus pares passariam a ser vistos de uma nova forma por mim, como eu mesmo seria transfigurado em suas maneiras de recepção da minha presença. Mal sabia eu que o mesmo efeito se daria estudando grupos "desconhecidos". Evitando alongar essa passagem desestabilizadora do início de meu percurso etnográfico (cf. Silva, 2009), resumo-a com a lucidez de Mariza Peirano (2014) ao afirmar que "a etnografia abala nossos estilos de vida e nossas ideias de existência; abala nossa crença moderna na referencialidade dos sentidos e impõe uma reflexão sobre a multiplicidade de modos de vida" (Idem, 2014, p. 385). Por essas e outras razões, dei continuidade a este projeto inicial no curso de mestrado, no qual sigo me transformando neste artesanato intelectual (cf. Mills, 2009) que constitui minha feitura antropológica.

Portanto, comecei a pensar numa maneira de estabelecer um grupo de interlocutores que não estivesse no contexto de minhas relações pessoais no candomblé. Embora possível, minha primeira tentativa revelou-se desgastante e infrutífera. Foi quando percebi que tinha diante de mim as pistas fundamentais para atingir de uma maneira aparentemente mais eficaz o meu objetivo.

No mês de Agosto de 2013 eu havia iniciado o primeiro de uma série de 
cursos de extensão sobre temáticas diversas relacionadas ao candomblé. Nesta ocasião, tratava-se do curso "África, fé e animismo", ministrado no espaço Centro Loyola de Fé e Cultura (PUC-RJ). O público deste curso era composto por sacerdotes e iniciados no candomblé, abiãs e curiosos interessados no tema.

Neste momento iniciei uma rede de contatos que foi se alargando no que eu chamo de um circuito cultural do candomblé, através de outros cursos do mesmo gênero em instituições como a UERJ, o Museu de Arte do Rio de Janeiro (MAR) e o Instituto de Pesquisa e Memória Pretos Novos (IPN-RJ). Do final de 2013 ao primeiro semestre de 2016 venho realizando uma profícua interlocução com esses religiosos, dos quais apenas uma parcela fará parte de maneira mais direta deste estudo, devido às necessárias delimitações.

Como ressaltado na introdução, o núcleo de minha investigação é um grupo de abiãs e suas múltiplas maneiras de vivenciarem o período de abianato, no qual pretendo analisar suas performances como etapa preliminar constituinte do processo de iniciação religiosa (feitura) em alguns candomblés no Rio de Janeiro. Lanço-me neste projeto na tentativa de apreender (cf. Geertz, 2001, p. 84) a experiência do abianato no sentido "da compreensão, da percepção e do discernimento" (Idem, 2001, p. 84), e não “'compreender' no sentido da concordância de opiniões, da união de sentimentos ou da comunhão de compromissos" (Idem, 2001, p. 84), pois acredito que "devemos aprender a apreender o que não podemos abraçar" (Idem, 2001, p. 84).

$\mathrm{Na}$ trajetória de observação participante, conversas informais e entrevistas semiestruturadas, houve intervalos e dificuldades de disponibilidade de ambas as partes. As entrevistas formais que utilizo foram realizadas nos anos de 2013, 2014 e 2016. Em muitos momentos não foi possível uma observação mais direta dos rituais internos de alguns terreiros. Assim, há casos em que tive maior acesso às festividades públicas, realizando entrevistas com os abiãs e/ou sacerdotes.

É fundamental dizer que em determinadas circunstâncias, alguns líderes religiosos se disponibilizaram para entrevistas, mas não possuíam abiãs em seus templos, na ocasião. Em outras, consegui entrevistar os abiãs, porém seus sacerdotes não me concederam entrevistas. Mesmo que a princípio meu tema seja percebido como "inofensivo" ao olhar desconfiado de certos pais e mães-desanto, tive a impressão que a possibilidade iminente do debate sobre as relações hierárquicas provocou certa relutância de alguns deles em participarem da 
pesquisa. Aliado a isso, há uma enorme dificuldade de agenda por parte dessas lideranças. Ou mesmo, quando marcavam uma conversa ou entrevista, estas eram interrompidas pelas intensas atividades dos terreiros, levando-me a passar quase dias inteiros para conseguir tal intento. De fato, todo este processo resultou literalmente numa aventura antropológica, visto os inúmeros imponderáveis com os quais me deparei, como visitas marcadas em regiões longínquas que os sacerdotes não compareceram ou um tiroteio no local de encontro para uma entrevista. Houve também uma oportunidade curiosa na qual, embora eu não tenha conseguido uma entrevista sequer de uma mãe-de-santo cinquentenária no candomblé, ela confessou sua profunda surpresa pela abordagem a respeito do abiã. Segundo ela, jamais havia parado para pensar no rito iniciático por este prisma. $\mathrm{O}$ que me fez crer ainda mais na relevância de minha proposta.

No mais, não foram os sacerdotes que mais apreciaram o tema de meu estudo, o que os levou a sugerir novas temáticas e numerosa bibliografia, confirmando a usual interface entre oralidade e escrita nos terreiros, conforme notou Lisa Earl Castilho (2010). Em verdade, não é que demonstrassem claramente um desprezo pela proposta apresentada por mim, mas em pouco tempo se detinham em assuntos que julgavam bem relevantes e urgentes para um debate público sobre a religião. Como exemplo, cito o tema da imolação animal e dos ritos fúnebres no candomblé (axexê), que preparam o iniciado para o último estágio da trajetória religiosa. Uma das sacerdotisas reclamou a ausência de estudos nessa área. Em seu terreiro era desenvolvido um culto particular aos ancestrais (Lessé Egúngún) ${ }^{15}$, para o qual fui convidado na ocasião de uma de suas cerimônias. Neste diálogo etnográfico (cf. Silva, 2006) constante com as lideranças, relutei bastante internamente para não me perder de minha motivação

\footnotetext{
${ }^{15}$ Lessé Egúngún: Significa propriamente “aos pés dos ancestrais”. Trata-se de um culto específico aos ancestrais masculinos de uma comunidade (egbé). Em algumas regiões da África, consiste em um culto paralelo ao Lessé Orixá (aos pés do orixá). No Brasil, a segunda modalidade difundiu-se com maior proeminência. A modalidade Lessé Egúngún está baseada no conceito filosófico afro-brasileiro de que a vida é um eterno ciclo nascimento-morte-nascimento. Assim, os adeptos dessa tipologia religiosa acreditam na imortalidade da alma. Para eles, os mortos renascem no espaço imaterial do universo (orun) no qual os ancestrais que um dia tiveram uma experiência material formam uma nova comunidade (egbé orun). Através de procedimentos iniciáticos e cerimoniais próprios, esses ancestrais chamados babá Egún (pais ancestrais) são evocados para proteger e aconselhar os que ainda vivem na dimensão material (aiê). Na ilha de Itaparica/ Bahia, encontram-se as mais exemplares manifestações dessa crença. Porém, em alguns terreiros de candomblé de outras partes do Brasil também é possível identificá-la. Para um maior aprofundamento ver: Santos (1981; 2002); Sant'Anna Sobrinho (2015).
} 
inicial ao penetrar nessa floresta de símbolos (cf. Turner, 2005) que é o candomblé.

Uma sugestão que me recordo bem foi no dia em que uma destas lideranças instruiu-me a publicar este trabalho em fascículos a preço popular na internet, ao invés de transformá-lo em livro. Em sua opinião, isto facilitaria o acesso dos leitores e garantiria um bom retorno financeiro de todo meu investimento. Ela mesma pensava em produzir um material do gênero, como me confessou mais de uma vez. Noutra ocasião, fui apresentado pessoalmente por esta mesma sacerdotisa a um pai-de-santo que prontamente se disponibilizou para participar da pesquisa. Logo me empolguei, pois sabia que ele possuía uma boa reserva de abiãs no seu terreiro. Mas, quão grande foi minha decepção ao ser prontamente "enrolado" por ele, nos consecutivos contatos que fiz na semana seguinte, quando pude concluir que aceitou meu convite, pelo simples embaraço de negá-lo diante da mãe-de-santo sua amiga.

Da parte dos abiãs, notei duas motivações muito nítidas ao serem convidados para uma entrevista. Primeiramente, muitos deles ficavam orgulhos e até vaidosos do convite, o que pode ser explicado por sua posição sempre satélite em relação aos acontecimentos do candomblé, e a consequente possibilidade de inversão focal simbólica que a oportunidade oferecia. Participar de uma pesquisa como essa, como alguns me confessaram, significava uma excelente vivência ou oportunidade, que eu traduziria como uma forma de reconhecimento de seus papeis.

Segundo, como em alguns casos o acesso aos abiãs partiu de indicações sacerdotais, esta participação implicaria também a realização de um pedido subentenda-se, uma vontade ou ordem - de seus pais e mães rituais. Isto nitidamente gerava uma imediata solicitude, que era por vezes esclarecida no meu primeiro contato (“ah... a mãe fulana pediu né... a gente faz logo!”). Ao longo da pesquisa, detectei uma relação emocional bastante intensa entre o abiã e os pais e mães-de-santo, neste período do abianato, que é explicado por eles frequentemente pelo uso da metáfora do namoro.

Todavia, nada disso deixou passar desapercebida a profunda insegurança ou mesmo desconforto inicial quando realizávamos entrevistas formais. Em todos os casos, quando me apresentava como pesquisador diante dos líderes religiosos ou dos abiãs, esclarecia imediatamente meu pertencimento religioso. Inicialmente, 
até acreditei que isto poderia ser um elemento facilitador de minha incursão no campo, mas logo descobri que esta informação poderia também operar como um dificultador das aproximações.

Entre algumas lideranças, isso gerava o que chamo de certa insegurança competitiva, pois eu tinha não apenas uma procedência acadêmica, mas portava também parte do capital simbólico que eles desfrutavam na construção de suas identidades. E, no que concerne aos abiãs, havia sempre a preocupação de me alertarem para o seu conhecimento superficial do culto, o que talvez pudesse gerar o embaraço de não conseguirem responder "corretamente" algum tipo de questionamento. Afinal, esta nova experiência estava muito além de seus repertórios como abiãs. Entretanto, dentro de alguns minutos do desenrolar das entrevistas, esta tensão se desfazia paulatinamente.

Embora eu não houvesse considerado esses possíveis desconfortos iniciais de ambos os grupos de interlocutores, duas outras preocupações me ocorreram de antemão: o anonimato dos participantes e o local das entrevistas, sobretudo no caso dos abiãs. No entanto, ao contrário do que prospectei, na maioria das vezes em que declarei o uso do anonimato na realização da pesquisa, boa parte deles não se mostrou avessa à publicização de seus discursos. Nem mesmo os casos de abiãs que abandonaram suas casas de axé. Mas, como não formalizei as autorizações, manterei a proposta do anonimato. Quanto ao grupo sacerdotal, em nenhum dos casos isso demonstrou ser uma inquietação.

Assim sendo, a única precaução na qual investi rigoroso esforço foi a seleção de locais "neutros" para os momentos de entrevista formal, principalmente com os abiãs. Todas elas foram realizadas em locais desassociados do terreiro ou mesmo do contexto religioso. Aos espaços regidos pelos códigos de hierarquia releguei as conversas informais e a observação. Para as entrevistas semiestruturadas, utilizei espaços públicos da cidade, bibliotecas ou mesmo a minha residência, de acordo com a preferência dos entrevistados. Sendo a participação do abiãs no candomblé submetida a um rígido controle hierárquico e um constante desconforto pelo posicionamento ainda ambíguo típico dos seres liminares (cf. Turner, 2013), percebi acertadamente que a "neutralidade" de tais espaços favoreceria a criação de uma atmosfera mais descontraída e livre. Nos estudos do candomblé, o pesquisador poderá ter diferentes graus de acesso aos seus interlocutores, sempre dependendo da posição que estes ocupem no cenário 
do terreiro, pois "a estrutura hierárquica que localiza as pessoas por sua senioridade iniciática, cargo e importância no grupo, dificultam um diálogo indiferenciado do antropólogo com todas as pessoas do terreiro, ao menos de forma explícita ou oficial" (Silva, 2006, p. 39).

Obviamente, tenho a noção exata de como, mesmo distante fisicamente da instituição religiosa e de seus representantes oficiais superiores, há um vínculo moral dos abiãs com as comunidades litúrgicas em que estão social e religiosamente inseridos, o que denuncia a existência de um poderoso dispositivo de poder e controle operando, mesmo sem bases materiais visíveis, posto que interiorizado no próprio corpo do indivíduo (cf. Foucault, 2012). Com isto, o recurso que utilizei para os encontros formais visou apenas um abrandamento momentâneo deste dispositivo de controle.

Pela imposição pragmática de tempo, ao qual o trabalho acadêmico está submetido, utilizarei doze entrevistas formais que realizei com abiãs nos anos de 2013, 2014 e 2016. Porém, não trarei para o campo de análise todas as entrevistas com sacerdotes. Como a preocupação fulcral deste projeto é a experiência do abiã, darei total ênfase para esta parcela do material etnográfico adquirido. No âmbito das lideranças religiosas, priorizarei apenas os dois casos em que consegui estabelecer uma visitação mais sistematizada das atividades internas e públicas de seus terreiros, respectivamente, o de mãe Dora e o de pai Carlito (ambos na zona oeste do Rio de Janeiro). Os abiãs, por outro lado, frequentavam terreiros de diversas regiões, como zona oeste/RJ, zona norte/ RJ, Maricá, Pedra de Guaratiba, Itaguaí e Magé.

No período de captação de participantes para a pesquisa, o único critério de seleção que empreguei foi a autodesignação como candomblecista, visto ser exclusivamente esta a modalidade de religiosidade de matrizes africanas no Rio de Janeiro, na qual a categoria do abiã é recorrente. Portanto, não houve um recorte de gênero, de classe, de região, ou qualquer outra variante. $O$ grupo de interlocutores da pesquisa formou-se de acordo com a disponibilidade ocasional dos participantes. No circuito cultural citado anteriormente, sempre procurava me apresentar e falar do projeto, tentando estreitar o contato com as pessoas que se mostravam interessadas em participar. Portanto, o grupo de religiosos participantes deste estudo adquiriu tal configuração pela adesão espontânea das pessoas interessadas em participar do mesmo. Todas as entrevistas formais que 
realizei tiveram gravação apenas de áudio. E nenhuma das imagens de pessoas que aparecem no corpo desta pesquisa corresponde aos entrevistados.

Notando no campo a importância do critério de classificação por "linhagens" dos praticantes do candomblé - há uma noção difundida de nações de origem étnica ${ }^{16}$, gerando modalidades do culto - saliento que os doze abiãs entrevistados pertencem ao eixo identitário Jeje-Nagô. Assim como, os dois sacerdotes que fazem parte desta pesquisa, seguem o mesmo padrão identitário. Apenas no bojo de outras entrevistas que realizei, mas não utilizarei, apareceram pertenças distintas unicamente por parte dos sacerdotes. Por conseguinte, todos os componentes do grupo que constitui a base empírica deste estudo, estão enquadrados na mesma modalidade de culto, ou seja, Jeje-Nagô. Doravante, toda a terminologia ritual utilizada neste estudo foi percebida como de uso comum por todos os participantes envolvidos.

\section{1}

\section{Abiãs - A escalação do "elenco" de performers}

[o abiã] não é simplesmente aquela pessoa que frequenta como assistente não! Você pode falar assim... então todo mundo que não é iniciado é um abiã? Não concordo. Porque muitas vezes a pessoa é um simpatizante, é um frequentadô da casa, como assistente da casa e ele não é um abiã, porque o abiã está ligado a um comprometimento. Então é aquela pessoa que entrô pra casa e se comprometeu com o axé, mas não é iniciado. Esse sim é um abiãa! Então o abiã é aquela pessoa que pertence à casa como filho-de-santo e simplesmente não se iniciou. Esse é o abiã! (pai Carlito)

Ao subir as rampas da UERJ naquela tarde de novembro de 2013, jamais imaginei que estaria prestes a encontrar o abiã que me concederia a primeira entrevista para minha pesquisa sobre o abianato no candomblé. Até então, não havia conseguido nenhum abiã disposto a ser entrevistado formalmente. E, numa enorme surpresa, já começava a empreitada antropológica encontrando o que eu julgaria ser mais difícil, um abiã que houvesse abandonado algum terreiro. Nada

\footnotetext{
${ }^{16}$ Nações de candomblé: termo difundido para demonstrar um sistema classificatório interno dos candomblés, seguindo uma lógica de relação parental ritual dos terreiros com possíveis reinos africanos originários. De forma geral concentram dois grandes eixos: o Jeje-nagô (Queto, Ijexá, Jeje-Fon, Jeje-Marrin) e o Banto (Angola, Quimbundo etc.). Inúmeros estudos (Silva, 2005; Parés, 2007 etc.) apontam para a relevância dessa classificação na construção de identidade e legitimidade dos mesmos. Porém, a discussão acerca da artificialidade dessas subdivisões não compete ao presente estudo.
} 
mais excitante para um antropólogo do que um caso desviante.

"Meu nome é Patrícia, mas pode me chamar de Paty! (risos). Olha, mas eu sou abiã ainda. Serve?". Foi assim que uma simpática jovem recém ingressa ao curso de pedagogia se apresentou para mim naquela tarde, no intervalo de um evento acadêmico, em que a convidei para participar de uma pesquisa sobre o candomblé. Ela não imaginava ser tudo que meu instinto etnográfico buscava naquele momento. Eu estava diante de uma excelente oportunidade para adquirir um valioso material etnográfico capaz de enriquecer de forma contrastiva minhas observações no campo, pois era óbvia demais a satisfação dos abiãs que estavam nos terreiros observados até então. Eu pretendia conhecer outras facetas desta experiência tão complexa na vida de um devoto que recentemente aderiu a esta modalidade religiosa.

No meio de uma palestra a respeito dos orixás e suas relações com os elementos da natureza, esta jovem de dezenove anos se levantou, e num tom humorado, fez uma pergunta a respeito de $E x u^{17}$ - divindade sobre a qual um palestrante havia proferido bela explanação filosófica iorubá - levando em consideração as práticas mais esdrúxulas de que temos notícia entre o povo-desanto, tais como amarrações amorosas e outros "serviços", ditos "para o mal". No auditório, alguns risos e sussurros ecoaram, mas logo percebi que se tratava de uma pergunta originada da real falta de vivência prolongada no candomblé e sua consequente avidez por esclarecimento. O desenrolar da situação não vem ao caso por ora, mas tive a intuição de que aquela jovem poderia talvez me ajudar.

Cuidadosamente fixei meu olhar na sua atuação, e logo ao término da palestra me apresentei como pesquisador e perguntei sua pertença religiosa específica no amplo espectro das religiões de matrizes africanas. Para minha surpresa, a jovem universitária era uma abiã que acabara de ter sofrido uma profunda decepção num terreiro de candomblé em Magé. Segundo Patrícia me

\footnotetext{
${ }^{17}$ Exu: nas Américas, esta é uma das divindades mais populares e polêmicas do panteão jeje-nagô. Ele tem sob sua regência o dinamismo da existência e, portanto, todas as formas de comunicação. No Brasil colonial houve uma equiparação equivocada deste orixá com o diabo cristão, dando origem a um estigma que perdura até os dias atuais. $\mathrm{O}$ penteado fálico e o chifre, símbolos de poder em culturas africanas, transfigurou-se numa aproximação ao demônio cristão. Vagner Gonçalves da Silva (2015) ressalta que sua insígnia fálica (opá ogó) relacionada à fertilidade, foi também associada à sexualidade e às vassouras das "bruxas" medievais, reforçando seu caráter desmedido e temível.
} 
confidenciou de primeira, ela havia passado pelo chamado golpe do bori feitura ${ }^{18}$, no qual seu pai dispendeu sete mil reais para a realização do serviço religioso. Assim sendo, embora estivesse bastante feliz com a descoberta "da presença de seu orixá em sua vida", era grande a decepção com os líderes da religião naquele momento. Ao longo da pesquisa fui percebendo que Patrícia e outros interlocutores faziam questão de reforçar esta diferença, tanto para justificar a adesão, quanto o rompimento com as casas de santo.

Assim começou o primeiro de uma série de encontros nos quais pude conhecer a angústia e a experiência de abianato desta jovem. Trocamos contatos e até o ano de 2014 nos encontramos nos seus intervalos das aulas de pedagogia. Numa cabine privada da biblioteca da UERJ, devido à acústica mais favorável, realizamos também algumas entrevistas formais, nas quais obtive as falas que cito neste estudo.

Patrícia, na ocasião de nosso encontro, estava há quatro meses afastada de seu terreiro. Até então, nunca houvera feito parte efetivamente de nenhuma outra religião. Durante a infância foi batizada na igreja católica e já visitara um templo de Testemunhas de Jeová. Em nenhuma dessas formas religiosas ela havia encontrado identificação. No entanto, aos dezesseis anos, teve seu primeiro contato com as religiões afro-brasileiras, através de um centro de umbanda ${ }^{19}$. Nesta época, sua visão a respeito do candomblé era de que se tratava de "magia negra" e, portanto, não via com bons olhos o culto aos orixás. Como me explicou, entre os umbandistas de seu círculo de convivência "falava-se horrores do candomblé, coisas horríveis mesmo!"’. Porém, Patrícia acabou por conhecer uma pessoa feita que convidou-lhe para um primeiro contato mais próximo com o candomblé: uma saída de Xang $\hat{o}^{20}$ num terreiro de Queto. Justificando ter aceitado

${ }^{18}$ Bori feitura: de modo geral, os candomblecistas utilizam esta expressão para se referirem a uma falsa feitura. O bori é um rito propiciatório de reequilíbrio para os acólitos e não significa iniciação, nem mesmo laço simbólico efetivo com a comunidade litúrgica. Na etiqueta religiosa hegemônica do candomblé, nunca é equiparado ao ritual de feitura. Segundo fui informado no campo, sacerdotes inescrupulosos se valem do bori feitura para conseguirem dinheiro de pessoas leigas em relação aos saberes da religião.

19 Umbanda: uma das modalidades religiosas afro-brasileiras. Sua prática ritual tem ênfase no culto a espíritos desencarnados conhecidos como entidades. Além disso, cultuam também alguns orixás de origem africana. Sua ritualística mantém forte sincretismo com o espiritismo e o catolicismo. Maiores aprofundamentos ver: Birman (1985); Magnani (1991).

${ }^{20}$ Saída de Xangô: entre o povo-de-santo, o termo saída é empregado para indicar o momento final da reclusão iniciática do neófito. Trata-se da primeira aparição pública do novo adepto, que neste caso foi iniciado para a divindade Xangô, que rege o elemento fogo na cosmologia do 
o convite me disse: "deixei um pouco de lado a resistência porque eu tenho uma natureza assim que eu preciso vê, né?" Segundo ela, foi impulsionada apenas por esta curiosidade que deu os primeiros passos rumo ao candomblé.

Seu primeiro contato direto com o culto foi justamente numa festa de orixá, que marcou-lhe tão profundamente a ponto de mudar sua concepção sobre o assunto. Como narrou diversas vezes, a primeira impressão foi apaixonante, devido à beleza e a intensa emoção que sentiu na festa. Vendo que não havia na ritualística nada de macabro como pensara outrora, começou a procurar avidamente mais informações sobre a religião e a visitar outros templos afrobrasileiros.

No decorrer de sua busca, a jovem acabou entrando para outro centro de umbanda, que frequentou por seis meses sem botar roupa ${ }^{21}$, mas continuava com sua imensa curiosidade pelo candomblé. Até que em outra circunstância, ouviu um batuque de atabaques no bairro onde morava e resolveu averiguar do que se tratava. Foi quando Patrícia descobriu o terreiro de candomblé no qual se tornaria abiã pela primeira vez:

Cheguei lá, estava tendo um xirê2 ${ }^{22}$. Eu não entrei, mas eu senti meu coração batê muito forte e falei: 'nossa, aqui é um lugar, sabe?' Me senti bem naquele lugar. Eu falei: 'eu quero ficar aqui'. E eu fui perguntar o que que precisava pra ser abiã. (abiã Patrícia)

$\mathrm{Na}$ sequência, ela estreitou sua relação com o terreiro e a mãe-de-santo, que após realizar um jogo de búzios ${ }^{23}$, revelou a necessidade da jovem de ser iniciada para sua divindade pessoal. Atordoada com a revelação e percebendo certa pressão da sacerdotisa ao longo do tempo, ela decidiu se afastar por um

candomblé. A saída é um momento em geral festivo e de muita relevância para a comunidade litúrgica. Mais adiante retornaremos ao tema.

${ }^{21}$ Botar roupa: expressão muito utilizada para designar o momento em que o religioso passa a fazer parte de um terreiro como membro. Por utilizar vetes rituais específicas que até então não faziam parte de sua rotina, a compra e/ou confecção e uso deste vestuário passou a designar o momento de adesão à religião. Vê-se o uso da expressão tanto na umbanda quanto no candomblé.

${ }^{22}$ Xirê: traduzindo do iorubá, significa festa, a roda de canto e danças em louvor aos orixás. É no momento do xirê que os filhos-de-santo iniciados entram em transe de orixá e executam a performance ritual da dança de orixá. Este é o momento clímax das atividades religiosas.

${ }^{23}$ Prática oracular utilizada no candomblé. Esta atividade é empregada nos cerimoniais e também como serviço mágico-religioso para a sociedade mais ampla. Configura-se por um grupo de 16 ou 21 conchas (espécie de moluscos) denominadas de cauris ou búzios entre o povo-de-santo. Conforme afirma Julio Braga (1988), trata-se de uma forma oracular que no Brasil foi adaptada do oráculo de Ifá africano desde meados do século XIX. Para maiores aprofundamentos ver: João José Reis (2008); Julio Braga (1988). 
período. Mas esta distância não tardou, pois aos dezenove anos, ela começou a apresentar vários sintomas de um possível afloramento mediúnico.

Num dia em que "passou muito mal" ${ }^{24}$, resolveu procurar a mãe-de-santo novamente, no que esta reiterou as necessidades espirituais da jovem. Com uma lista de quatro páginas de materiais litúrgicos para a realização do tal bori-feitura, Patrícia deu um passo oficial para sua pertença religiosa neste terreiro. Para isto, mobilizou ajuda de seus pais, que apoiaram prontamente o enorme dispêndio financeiro e emocional da empreitada religiosa. $\mathrm{Na}$ verdade, ela acreditou que passaria por um bori, que depois foi revelado pela sacerdotisa como sendo o que ela chamava de bori feitura.

Embora tenha se decepcionado bastante ao descobrir que a suposta mãede-santo não tinha reais condições e legitimidade para realizar as funções sacerdotais, sua experiência como abiã foi narrada como profundamente marcante e transformadora. Patrícia disse ter melhorado de sua depressão e, inclusive, ter passado no vestibular da UERJ, graças a esse primeiro contato com os orixás. Pela total falta de conhecimento do culto, ela declara ter sido enganada, já que pagou por um bori e a mãe-de-santo realizou desastrosamente práticas rituais típicas de uma feitura. Isto lhe teria acarretado inúmeros problemas no decorrer do tempo, já que no início ela estava fazendo tudo de coração como abiã.

Por esta razão, Patrícia acredita que inicialmente teve bons resultados, mesmo que tenha sido tudo uma enorme marmotagem ${ }^{25}$ da sacerdotisa. Hoje, a jovem estudante procura com muitas ressalvas encontrar um templo no qual possa dar prosseguimento a carreira religiosa e "consertar" os supostos erros rituais dos quais alega ter sido vítima. Contudo, além de descobrir a experiência do orixá em seu próprio corpo, pôde pela primeira vez concretizar uma escolha religiosa, que

\footnotetext{
${ }^{24}$ Frequentemente os adeptos das religiões afro-brasileiras utilizam o termo passar mal para se referirem aos sintomas provocados no corpo, devido à ação dos orixás e das entidades. As descrições de tremores involuntários, imobilidade, sudorese intensa, dormência, tontura ou mesmo desmaio, configuram um quadro muito similar aos sintomas de alguns problemas de saúde. Por tal semelhança dos sintomas, a expressão passar mal acaba sendo aplicada para demonstrar essa transição entre o estado de "normalidade" e o de possessão, no qual o transe é precedido por um desequilíbrio generalizado do corpo do adepto. Em contraponto, após esta experiência desestabilizadora, as descrições são as melhores possíveis. No quarto capítulo voltaremos ao tema.

${ }^{25}$ Marmotagem: categoria nativa para designar tudo que não corresponde ao padrão dito correto e legítimo da ritualística do candomblé. Expressa sempre uma ideia de falsificação ou farsa. É nítido o tom jocoso no uso corrente da expressão. A identificação das marmotagens é assunto constante nas redes de sociabilização do povo-de-santo.
} 
mesmo sendo conturbada e traumática, não havia arrefecido sua fé e identificação com o candomblé:

A primeira religião que eu fui porque eu quis foi o candomblé. [...] Quando eu pisei num terreiro de candomblé, parecia que eu era... eu me senti absoluta! Eu comecei a confiar em mim, a confiar no meu orixá, a saber que eu não estou sozinha. [...] Não acho o candomblé uma escolha. [...] a escolha não vem de você, o orixá que te escolhe. [...] Quando você escolhe essa religião você não sabe o que é ainda. Você conhece superficialmente. O candomblé, ele tem muita coisa boa, muita obrigação, muita dedicação numa casa". Porque a casa é como se fosse a sua casa. [...] Mas o candomblé é a nossa casa. [...] Eu gosto de me sentir em casa. No candomblé eu estou em casa! (abiã Patrícia)

A percepção do acolhimento é bastante recorrente nos discursos dos abiãs que participaram deste estudo. As duas impressões mais descritas por eles são exatamente o encanto, através dos múltiplos estímulos sensoriais despertados pelo forte apelo estético do culto, e a reconfortante acolhida recebida nos terreiros. Como poderemos ver claramente, o templo litúrgico afro-brasileiro - em oposição ao espaço ameaçador da rua - é referenciado constantemente pelo uso do termo casa, que evoca na subjetividade dos fiéis a ideia de um "espaço de calma, repouso, recuperação e hospitalidade, enfim, de tudo aquilo que define a nossa ideia de 'amor', 'carinho' e 'calor humano"' (DaMatta, 1997, p. 52). Ao declarar que "sente-se em casa", Patrícia deixa transparecer a representação do terreiro como local de refúgio de um mundo feito de inseguranças e ameaças, para o qual a casa (no caso, de candomblé) remete a uma situação “onde as relações são harmoniosas e as disputas devem ser evitadas" (DaMatta, 1997, p. 50). Obviamente, a realidade empírica irá revelar-se muito mais complexa do que a jovem ainda poderia supor na sua aproximação incipiente deste universo religioso. Como a própria vida, este espaço é muito mais complexo e rico em nuances.

No rastro do tema do acolhimento $^{26}$ propiciado por essas casas de axé, passo para a abiã Paula de 28 anos, que conheci no terreiro de pai Carlito na zona oeste/RJ. Realizamos nossa entrevista em minha casa um ano antes de sua iniciação ritual. Segundo me contou na época, Paula trabalhava como assistente administrativa no departamento de recursos humanos de uma empresa. O trabalho de sua mãe era próximo ao terreiro de pai Carlito, o que facilitara o encontro com

\footnotetext{
${ }^{26}$ Este acolhimento proporcionado nos terreiros refere-se não apenas ao âmbito emocional dos adeptos, mas em muitos casos numa verdadeira assistência em áreas de grande vulnerabilidade social. Ver maiores informações sobre a rede social de solidariedade nos terreiros em Fonseca \& Giacomini (2013).
} 
o sacerdote pela primeira vez.

$\mathrm{Na}$ minha inserção inicial neste barracão, havia uma reserva de abiãs considerável no primeiro ano, mas antes que eu conseguisse conciliar as agendas para formalizar algumas entrevistas, no período seguinte de férias escolares, foram realizados os rituais de feitura do grupo. Apenas em 2014, entraram novos abiãs, dos quais destaco a entrevista de Paula, que ingressou para o terreiro inicialmente apenas na parte de umbanda.

Pai Carlito, nos primeiros anos que implantou o candomblé, deixava que cada membro decidisse participar ou não dos chamados rituais de nação ${ }^{27}$. Era um terreiro híbrido, ou seja, um candomblé que ainda praticava separadamente a umbanda que o originou. Ao longo da pesquisa, percebi que a expansão do templo mudou bastante o posicionamento do líder religioso quanto à participação dos filhos-de-santo nos eventos litúrgicos propostos.

Foi aos seis anos de idade que Paula começou a conviver no universo do candomblé, já que sua mãe e avó materna haviam se iniciado na religião. Sua parte familiar paterna que era toda evangélica, levou-a às igrejas sem que ela jamais se convertesse. Por outro lado, na companhia da mãe e da avó ia para a roça de santo e ficava brincando com as outras crianças enquanto aconteciam os rituais. Ela lembra que não gostava muito do ambiente com seus cheiros estranhos e os bichos das imolações. Entretanto, foi apenas aos doze anos, que Paula começou a "passar mal" em suas idas aos candomblés. Porém, com o falecimento do zelador ${ }^{28}$ de sua mãe, elas deixaram de frequentar os terreiros definitivamente.

Por volta dos vinte anos, mesmo longe do candomblé, Paula recomeçara a "passar mal", além de estar enfrentando inúmeros problemas na vida pessoal, com “as coisas não acontecendo, atrasando!”. Na tentativa de ajudá-la, sua mãe aconselhou-a a fazer um jogo de búzios com um pai-de-santo, que ela havia conhecido. Por conseguinte, foi confirmada pelo oráculo a necessidade de feitura, mas Paula não aceitava o candomblé ainda. Então, ela realizou alguns serviços rituais sem estreitar laços com o barracão nem o sacerdote. Não concordava com

\footnotetext{
${ }^{27}$ Expressão recorrente entre meus interlocutores para se referir a tudo que era específico ao candomblé. Ocorre o emprego em várias situações: roupa de nação, santo de nação, cantiga de nação, casa de nação etc.

${ }^{28}$ Zelador ou zeladora (de santo ou orixá): como pontuei em nota anterior, é outra expressão nativa correlata aos termos pai-de-santo e mãe-de-santo. Introduzo a expressão pelo uso dado pela informante.
} 
a ritualística, nem sentia afinidade alguma com o zelador e a casa de santo. Logo percebeu que havia um grande interesse material e uma certa pressão para a realização de sua feitura. Assim, decidiu se afastar novamente, até que uns seis meses depois voltou a "passar mal". Ela brincou dizendo que os preceitos ${ }^{29}$ tiveram um curto prazo de validade desta vez.

Cônscia de sua necessidade de fazer o santo e cansada de "passar mal", foi através do jogo de búzios de pai Carlito que se convenceu da necessidade de botar roupa. Embora tenha refeito os procedimentos rituais possíveis para amenizar a dita "cobrança" do orixá, ingressou ao terreiro, já avisada, de que este seria o único caminho a dar fim ao sofrimento. A política diferenciada de pai Carlito, que segundo ela, não forçava os filhos-de-santo a nada, fez com que ela se encorajasse a tentar o desenvolvimento da mediunidade. Seu marido, que detestava a religião passou a acompanhá-la nas giras $^{30}$ de umbanda. Mas não tardou para que ele também buscasse no jogo de búzios deste sacerdote, a solução para algumas dificuldades que vinha enfrentando.

Ao término de alguns meses, vi que ambos ingressaram no terreiro e já estavam, inclusive, participando dos toques $^{31}$ de candomblé. No caso deste barracão da zona oeste/RJ percebi que muitos casais e famílias aderiam juntos ao culto. Este era um traço bastante marcante da configuração do grupo. A referida política do pai-de-santo parecia realmente bem distinta de alguns padrões comportamentais vistos em outros terreiros, que enxergavam como um tabu casais se tornarem irmãos-de-santo. No tocante a subdivisão interna do templo entre rituais de umbanda e candomblé, conforme ela fazia questão de ressaltar, o paide-santo era bastante flexível quanto à participação dos membros.

Por vontade própria ela e seu marido começaram a visitar as festas no candomblé para conhecer melhor este outro lado da casa. Ela me relatou sua profunda emoção diante da beleza das festas. Inclusive, depois de algum tempo

${ }^{29}$ Preceitos: expressão nativa genérica para designar os rituais de limpeza e fortalecimento espiritual conhecidos também como ebós e boris. A categoria de ebó engloba uma tipologia infinita de oferendas realizadas através da manipulação de diversos elementos dos três reinos (animal, mineral e vegetal), no qual o corpo do suplicante é fundamental para sua realização.

${ }^{30}$ Giras ou sessões são os nomes dados aos rituais públicos de umbanda, nos quais o canto e a dança permeiam a manifestação das entidades. É nas giras que vemos a manifestação típica da performance dos umbandistas. Maiores aprofundamentos ver: Birman (1985); Magnani (1991).

${ }^{31}$ Toques: expressão nativa para se referir à festa de orixá. Por todo o cerimonial ser pontuado pela musicalidade dos atabaques, o toque se tornou um termo metonímico da festa. 
frequentando os toques, seu marido foi suspenso como og $\tilde{a}^{32}$. Creditando ao seu orixá o percurso até o candomblé, Paula ainda assim reivindicava para si a decisão final de ser feita. Afinal, a casa de santo havia sido escolhida por ela mesma, como relembrava no advento de seu casamento religioso. Lembro também do dia em que Paula e Wagner casaram-se numa cerimônia de umbanda celebrada por uma entidade de pai Carlito. Conforme diversos outros casos, notei na biografia desta abiã a relevância da forma de acolhimento recebido através do pai-de-santo e dos irmãos-de-santo, como um fator marcante para sua adesão ao grupo religioso:

Foi muito naquela de vou vê pra crê! Vamo vê se as coisas resolve. [...] Vamo vê se realmente vai sê a solução. [...] Foi muito bom. A receptividade foi muito boa! Quando todo mundo me abraço assim... foi muito bom! Não era o que eu esperava e era bem diferente do que eu já tinha visto lá na outra 'casa'. [...] Eu casei na umbanda e botei uns dizeres no DVD e tem uma parte que fala que família-de-santo a gente não escolhe. Mas isso não é verdade pra mim! Foi a família que eu escolhi. Me aceitaram e eu escolhi. Hoje eu convivo muito mais com essa família do que com minha família de verdade. Troco tranquilamente sem pensá muito, pra está com eles, do que pra tá com a minha família. São pessoas que me fazem muito bem. Me ajudaram muito, que eu gosto de está! (abiã Paula)

A história da abiã Paula e seu marido faz lembrar a trajetória de outro casal de abiãs que conheci em Pedra de Guaratiba no ano de 2013. Os abiãs Clayton e Caterine me foram apresentados pelo pai-de-santo André, na mesma época em que fazíamos o curso "África, fé e animismo" no Centro Cultural Loyola em Botafogo/ RJ, circunstância em que também conheci a mãe-de-santo Dora.

Embora eu tenha realizado excelentes entrevistas com o pai-de-santo André, a necessidade de delimitação do grupo estudado levou-me a não utilizá-las diretamente neste trabalho. Clayton e Caterine, respectivamente com 22 e 16 anos, eram namorados e moravam juntos no terreno da família da jovem. Ela chamava-o de "meu esposo", embora não fossem legalmente casados ainda. A trajetória de ambos estava bastante imbricada, já que praticamente foi ele quem apresentou Caterine ao candomblé.

\footnotetext{
32 Ogã é um cargo honorífico masculino no candomblé. Os portadores de tal posto assumem funções diversas que vão da execução musical dos ritos aos sacrifícios rituais. Há uma cerimônia na qual este adepto é identificado por um orixá manifestado e suspendido sentado numa cadeira para que toda a comunidade reconheça seu status. A suspensão de ogã é um ritual propiciatório, pois é somente na reclusão iniciática que este ogã será confirmado, como é dito entre os nativos.
} 
Clayton saíra de casa para ter maior liberdade para trabalhar no comércio e praticar a religião, já que o pai, além de não simpatizar com o candomblé, achava que o filho nessa idade deveria apenas estudar. Caterine era estudante ainda, mas procurava um emprego de forma que conseguisse alguma renda para custear sua feitura, que ela pretendia realizar o quanto antes, pois já vivenciava o abianato há dois anos com o namorado, quando eu os conheci. No primeiro semestre de 2014 estiveram em minha residência, levados pelo pai de Caterine para a realização das entrevistas formais. Nossos outros encontros foram nas diversas festividades do barracão.

Clayton, desde pequeno frequentou a igreja católica junto com a família. Foi batizado, fez catecismo, primeira comunhão e serviu à igreja como coroinha durante toda a infância. Quando criança teve um primeiro contato com as religiões afro-brasileiras através das festas de Cosme e Damião ${ }^{33}$ nos terreiros que visitava com amigos. Ele me relatou as lembranças das festividades e o curioso contato com os erê $^{34}$, mas não recordava se eram especificamente templos de umbanda ou candomblé.

Somente ao término da adolescência, que Clayton foi convidado por um amigo para visitar uma festa de Exu no barracão de pai André. Como sempre muito curioso, aceitou o convite ressabiado. A experiência da festividade causoulhe profunda comoção e atração, conforme me narrou. Então, começou a querer conhecer cada vez mais o universo do candomblé. Junto com seu amigo, que posteriormente tornou-se irmão-de-santo, continuou frequentando muitas festas e pesquisando na internet tudo que podia sobre o assunto.

Sua expectativa inicial foi descobrir qual seria seu orixá protetor ${ }^{35}$. Após

\footnotetext{
33 Santos católicos que foram apropriados pelas religiões afro-brasileiras como protetores das crianças. No dia desses santos são realizadas festas e distribuição de doces como forma de agradecimento pelas graças alcançadas pelos fiéis através de promessas. Na umbanda, estão associados aos espíritos infantis que "trabalham" nos terreiros.

${ }^{34}$ Erês: na umbanda referem-se aos espíritos infantis que se manifestam através dos médiuns. No candomblé, se relacionam a um estado transitório do transe, que antecede e encerra a manifestação do orixá. Neste estado, o comportamento dos neófitos é também infantilizado, como uma maneira de acessar uma típica disponibilidade infantil para o aprendizado das regras da religião. Conforme afirma Trindade-Serra (1981), no candomblé o erê realiza uma espécie de mediação entre o neófito e seu orixá.

${ }^{35}$ Acredita-se no candomblé que cada indivíduo possui uma relação ancestral com um determinado orixá. A iniciação ritual seria o processo pelo qual esta relação se tornaria mais estreita a ponto da divindade manifestar-se no próprio corpo do fiel. Nesta relação os fiéis acreditam-se protegidos pelas divindades nas diversas esferas de suas vidas. Portanto, uma das maiores curiosidades dos novos adeptos é a identificação destes protetores.
} 
ser apresentado ao pai-de-santo André, as visitações começaram a se restringir somente a esta casa de santo, na qual foi estreitando laços cada vez que participava de uma festividade em louvor aos orixás. No entanto, chegou um momento em que Clayton já estava decidido a ingressar efetivamente para o templo, pois já havia entendido e aceitado que encontrara ali a completude espiritual que nunca alcançou nos rituais da igreja católica:

[...] quinze anos que eu fui católico.[...] Já fiz tudo, cursei o catecismo, primeira comunhão, coroinha [...] não cheguei a terminá a crisma, mas quase fui crismado já [...] só que não me interessou mais. Realmente me interessou o candomblé e daí as festas [...] aí realmente parei de ir à igreja. Dois anos que eu tenho no candomblé, eu acho que realmente eu me encontrei mais com o candomblé do que quinze anos dentro da igreja católica. [...] Não é exatamente o tema da religião. [...] foi o candomblé que eu escolhi porque realmente me identificô muito. Tanto me ajudô, quanto eu me identifiquei lá dentro. Lá dentro, por causa das pessoas, dos rituais, porque os orixás realmente eles dançam! Mas transmite alguma coisa. [...] No candomblé, cada festa você vê... acontece alguma coisa diferente. Você sente uma coisa diferente. (abiã Clayton)

Novamente, como acontece na trajetória de boa parte dos adeptos desta religião, a próxima etapa de sua aproximação foi marcar um jogo de búzios. Prontamente, ele e seu amigo deram cabo do intento. Como é muito comum no ethos do candomblé, as pessoas que estavam familiarizadas com a presença de Clayton na roça de santo já estavam lançando muitos palpites a respeito de seu orixá protetor. A identificação do orixá de um indivíduo é a base necessária para os candomblecistas iniciarem suas interações interpessoais. Sendo assim, uma vez pai André tendo revelado a "genética espiritual" de Clayton, ele convenceu-se ainda mais da decisão de aderir à religião.

Porém, havia um pequeno entrave, pois a namorada era frequentadora de uma igreja evangélica junto com os pais. E, pelo que constava, eles iriam realizar o batismo dentro de alguns dias. É certo que Caterine já não estava tão envolvida com a igreja como estivera até o início da adolescência. Mas, por um comodismo e o receio de não contrariar os pais, ainda acompanhava-os em alguns cultos, conforme me confidenciou.

No afã de descobrir logo seu orixá protetor, ele e seu amigo Cássio, haviam esquecido e marcado o jogo de búzios justamente no dia do aniversário de namoro de Clayton e Caterine. Atrasado e esbaforido, ele retornou para casa da namorada que o recebeu furiosa. Porém, a situação serviu para que estabelecessem um acordo de que ambos visitariam o templo religioso um do outro. Foram essas 
visitações que acabaram despertando em Caterine a mesma atração descrita por todos os participantes deste estudo:

Eu era da igreja. Daí eu comecei a namorá com o Clayton, meu marido agora. [...] Aí ele começou a me levar em outros barracões. [...] Mas foi assim: primeiro a festa. Eu fui na primeira festa com meu esposo. [...] comecei ir em outras festas, me interessei mais pela situação. Aí eu gostei das anáguas, gostei dos paninhos branco e quis entrar. [...] Dentro da igreja, eu conheci o terreiro de Exu, né? [...] Fiquei numa paralela. Eu ia pra igreja, tinha festa no candomblé, eu ia. [...] Era como se eu fosse no candomblé e aí depois eu ia na igreja como se fosse pra pedir desculpa [...] Decidi a partir de então! Que eu vi que as festas eram muito bonitas. Porque a gente conhece pela festa! Sinceramente, a gente quer olhá a festa. 'Poxa é tão bonito! Por que eu não vou?' Aí depois você vai se aprofundando na ideia, na lógica, nos fundamentos. (abiã Caterine)

Como era menor de idade, Caterine precisou contar tudo aos pais, para que autorizassem seu ingresso no candomblé. Isto só aconteceu posteriormente ao dia do batismo na igreja, quando após os pais saírem da piscina batismal, a jovem em seu conflito interior, disse ao pastor que não estava preparada para tamanha responsabilidade e desistiu. Clayton, receoso dos pais dela proibirem o namoro, não revelou seu estreitamento de vínculos com o candomblé antes da namorada fazê-lo. Ao contrário de algumas histórias de intolerância familiar bem recorrentes entre os abiãs, os pais de Caterine respeitaram sua escolha religiosa mesmo com um pouco de receio. Por esta razão, ela credita seu ingresso na religião à sua decisão íntima, mesmo que em certo sentido transpareça em seu pensamento a ideia de uma determinação externa para alguns casos:

Eu tive a oportunidade de escolher entre a igreja e entre o candomblé [...] Mas é uma escolha. Pra qualquer pessoa. [...] Você pode querer sê e pode não querer sê. Depende da tua obrigação com isso. [...] sem sê esses casos assim mais extremos, eu acho que o candomblé realmente é uma escolha. Todo mundo tem esse direito. Independente da pessoa. (abiã Caterine)

Deste episódio em diante, ambos passaram a frequentar efetivamente o barracão de pai André. Muitas foram as festas e rituais internos através dos quais eles foram estreitando o envolvimento com os orixás e os membros deste terreiro. Paulatinamente, foram aprendendo novas formas de exercitarem a fé e reconstruírem suas identidades num contexto totalmente diverso do cristianismo, no qual foram educados desde tenra idade.

Somente no dia em que Clayton foi suspenso como ogã e sanou de vez sua dúvida quanto à possibilidade de entrar em transe, é que ele pareceu ter a certeza plena de ser admitido no novo ethos. Contudo, é justamente no transe de orixá que 
a performance ritual do adepto do candomblé atinge seu paroxismo. Neste mesmo dia, pude presenciar o momento em que Caterine "bolou" 36 pela primeira vez. É nítida em minha lembrança a expressão de felicidade e desconcerto de ambos nesta noite de festa para os orixás. Experiências marcantes como estas produzem na subjetividade dos devotos nuances acentuadas de pertencimento ainda maiores.

Após o bolar de Caterine e a suspensão como ogã de Clayton, ambos passam a se ver e a serem vistos pelo grupo com sutis diferenciações. Passam a ser ainda mais cobrados na execução de seus papeis como membros da comunidade litúrgica, assim como percebem uma maior pressão interna e externa para a concretização da feitura. Ao ser suspenso e/ou bolar é como se o filho-desanto atestasse publicamente, através da legitimação dos orixás, a sua razão de ser dentro da comunidade litúrgica. Como veremos, dentre as narrativas dos adeptos, há uma recorrente valorização daqueles que entram por necessidade, e não pela curiosidade ou um capricho pessoal.

Foi neste mesmo contexto que o pai-de-santo André indicou-me a abiã Regina para participar da pesquisa. Ela frequentava há dezoito meses o mesmo terreiro que Caterine e Clayton em Pedra de Guaratiba. Regina, uma senhora de 67 anos e aposentada, há dezoito meses vivia a experiência do abianato quando a entrevistei numa praça pública em Duque de Caxias, próximo a região onde ela morava. Este foi também um caso bastante curioso. Meses após nosso primeiro encontro, tive a oportunidade de reencontrá-la já feita em uma festividade de seu barracão.

Regina havia estudado em colégio religioso até o antigo ginásio, quando era obrigada a ir à missa aos sábados também. Porém, um dia ela se rebelou dizendo que não queria mais participar das missas aos sábados, porque já ia às de domingo que era o dia sagrado. Como sua mãe era muito rígida, castigou-a severamente logo que a madre superiora queixou-se da revolta de Regina. A abia contou-me esta história com enorme satisfação ressaltando sua forte personalidade.

\footnotetext{
${ }^{36}$ Bolar é um termo nativo para explicar a experiência de transe bruto no qual alguns adeptos são acometidos antes da iniciação. Sua representação é de uma experiência de "quase morte". Embora seja uma espécie de morte simbólica, os sintomas descritos pelos religiosos são bastante concretos. Na visão dos religiosos, é um sinal inconteste da necessidade de iniciação. Este tópico será melhor desenvolvido no capítulo 4 deste estudo, no qual considero o bolar como a performance ritual dos abiãs.
} 
Todavia, esporadicamente sua mãe também frequentava alguns terreiros em paralelo a igreja católica. E, segundo as histórias familiares, já houve até um tio de sua mãe que era pajé. Outro dado curioso enfatizado por seu discurso diz respeito a um pântano cheio de caranguejos, que eles visitavam de barco na infância. $\mathrm{O}$ tal tio pajé sempre insistia para que ela entrasse e que nada de mal lhe aconteceria, mas ela sempre teve muito medo. O interessante desta narrativa é vermos a associação que a abiã realiza entre seus dados biográficos e o universo cosmológico do candomblé. Regina tem como seu orixá protetor a divindade Nan $\tilde{a}^{37}$, que está justamente relacionada à lama. Nessa reminiscência da infância, ela demonstra como o orixá sempre deixou pequenos sinais de sua presença em sua vida. Frequentemente, ao contarem suas biografias "os adeptos estão sempre realçando alguns traços que lhes são significativos para, desse modo, compor sua 'carreira'" na vida religiosa (Lima, 2005, p. 72).

$\mathrm{Na}$ fase adulta, Regina também realizou alguns serviços mágico-religiosos num terreiro em Duque de Caxias no qual sua irmã frequentava. Mas foi numa consulta com uma pombagira ${ }^{38}$ em outro terreiro em São Gonçalo, que ela descobriu que precisava cuidar de um problema no seio. Por isso, procurou um médico e fez alguns ebós nesse mesmo barracão paralelamente.

Apesar de ficar quase boa, como afirmou, pensava: "será que isso que tá acontecendo é porque eu tenho que entrar?” Com isso, começou a se preocupar com suas questões espirituais cada vez mais. Sabendo que sua irmã havia ingressado no terreiro de pai André, Regina resolveu visitá-lo para conhecer melhor o candomblé. No entanto, logo começou a frequentar já "passou mal" e acabou bolando também. E foi o impacto deste fato que lhe deu o argumento decisivo para concluir sua suspeita de que a doença no seio constituía verdadeiramente um chamado do seu orixá. Consonante ao valor dado às biografias na "carreira" religiosa dos filhos-de-santo, "na maioria das trajetórias

\footnotetext{
${ }^{37}$ Nanã é a divindade feminina mais anciã do panteão jeje-nagô. Seu princípio na natureza é justamente a lama e as áreas pantanosas. Na cosmogonia iorubá difundida nos terreiros que pesquisei, esta divindade está relacionada à lama primordial da qual é feito o próprio ser humano, segundo a cosmologia jeje-nagô.

${ }^{38}$ A pombagira é uma entidade feminina bastante popular nos terreiros de umbanda. Mas sua presença em algumas casas de candomblé é cada vez mais comum. Esta entidade está associada à exacerbação do poder e da sensualidade femininas. As suas principais áreas de atuação seriam a vida amorosa e sexual do ser humano, segundo meus informantes. Para maiores informações ver: Birman (1985); Magnani (1991); Contins (2009).
} 
narradas, a aflição ganha destaque especial, particularmente a doença, como um sinal do chamado" (Lima, 2005, p. 72).

Depois de realizar um jogo de búzios com seu sacerdote, Regina decidiu que a feitura seria a solução de todas as suas aflições (cf. Fry et al, 1975), além do fato de ter percebido no seu terreiro um espaço bastante agradável de sociabilidade. Embora a apreensão fosse enorme, principalmente pela sua avançada idade, ela estava bastante determinada a dar continuidade no candomblé, principalmente por ter encontrado neste templo um acolhimento especial e a explicação de todos os fatos que viveu ao longo da vida, incluindo a não aceitação do cristianismo e uma suposta herança espiritual familiar. Interessa notar também, que sua aproximação foi inicialmente através das festividades, e seu discurso reitera o poder atrativo das festas sobre os visitantes, além de revelar a constante autopercepção da "plateia" que assiste a roda de santo:

Eu acho o candomblé uma religião que me chamou atenção, tá me fazendo bem e pode fazê bem prá outras pessoas também. [...] É uma escolha. A pessoa escolhe. Eu escolhi. Eu escolhi porque eu me senti bem, eu fui prum barracão que eu me senti bem. O pai-de-santo acolhe a gente muito bem, entendeu? [...] A aproximação que a gente tem são as festas, né? As festas dos orixás. [...] Tudo muito bonito, entendeu? Porque o candomblé tem um certo mistério. Principalmente as pessoas que vão assistir as festa, né? Ficam atraídas, olhando aquilo. Às vezes eu fico prestano atenção nas pessoas que tão em volta, prestano atenção na gente que tá ali naquela roda. É uma atração muito grande. (abiã Regina)

Feliz por finalmente ter se encontrado numa religião, Regina lançou-se com afinco para a experiência do abianato. Acompanhei também sua constante dificuldade de locomoção e coordenação dos movimentos com o ritmo dos cânticos. $\mathrm{O}$ uso da memória é também crucial numa etiqueta ritual extremamente complexa e calcada na oralidade. Muitos são os relatos da dificuldade de entender e pronunciar os termos da nova gramática litúrgica. Ao longo de muitas conversas percebia a dificuldade da abiã de pronunciar certos termos. Por exemplo, ela tentou me explicar que já possuía o chamado ibá or $\hat{\imath}^{39}$, mas que com dificuldade

\footnotetext{
${ }^{39}$ Ibá orí: sendo o orí (a cabeça) considerado uma divindade no candomblé, seu culto em alguns terreiros implica na confecção material de uma representação simbólica do mesmo. Esta representação feita numa tigela branca ou translúcida com diversos elementos em seu interior, recebe o nome de ibá orí. É sobre este pote sagrado que são realizados sacrifícios e oferendas regulares. Entre os adeptos do candomblé há bastante divergência quanto à necessidade deste elemento, pois alguns acreditam que a divindade orí já está situada desde o nascimento dentro da própria caixa craniana de cada pessoa. Ao contrário do orixá, que seria fixado no orí somente a partir da feitura. Para aprofundar o assunto ler: Marcio de Jagun (2015).
} 
ela dizia: “o baba... ba... barueri... como é mesmo, meu filho?”. Mas sua determinação foi enorme até o dia em que finalmente realizou sua feitura.

A exigência física do candomblé parece ser um grande desafio para as pessoas mais idosas que tenham a intenção de passar pela iniciação. Não apenas pelo farto repertório de danças, como também pelas inúmeras atividades rituais que englobam a cozinha votiva e as cerimônias sacrificiais e terapêuticas. Como me disse várias vezes mãe Dora: "o candomblé tem uma incidência física muito grande meu filho!”.

Entretanto, assim como o caso da abiã Regina, presenciei o enorme empenho de uma mãe-de-santo de umbanda que se tornou abiã no candomblé aos seus 56 anos. Janete tinha dois anos de abianato quando fomos apresentados por seu pai-pequeno ${ }^{40}$ num curso de cânticos litúrgicos em iorubá na UERJ em 2014.

O terreiro de pai Josemar, que visitei algumas vezes em 2014 e 2015, localiza-se em Maricá. Mesmo com toda a distância e dificuldade de conciliação de horários, entrevistei formalmente a abiã Janete às vésperas do ritual de sua iniciação. Um de nossos encontros foi em Niterói, quando ela e a abiã Devanilda compravam os últimos elementos votivos para a reclusão ritual de Janete. Após acompanhá-las nas compras, realizamos as entrevistas num shopping da região. Inclusive, foi bastante difícil encontrar um local com uma acústica favorável para a gravação do áudio. Elas estavam bastante ansiosas com o recolhimento de Janete e com o desconforto de serem entrevistadas por um antropólogo - do qual não entendiam exatamente o ofício - que já era um iniciado no candomblé. Foram muitas as ressalvas que fizeram a respeito de seus incipientes saberes rituais. Aliás, boa parte dos abiãs ficava muito receosa com esta questão.

Janete, embora já fosse mãe-de-santo de umbanda há décadas, estava entrando para o candomblé para realizar a feitura por cobrança de seu orixá. Ela era categórica ao afirmar que não foi uma escolha dela, pois pretendia permanecer apenas na sua amada umbanda até então: "Santo comanda a vida da gente. Nem tudo que a gente quer, a gente faz. Eles determinam e a gente segue”. A lembrança mais remota que tinha de seu contato com o universo das religiões afro-brasileiras

\footnotetext{
${ }^{40}$ Pai-pequeno ou babá quequerê: cargo sacerdotal da pessoa que se posiciona logo abaixo ao paide-santo. Em sua ausência poderá substituí-lo. Seu correlato feminino seria mãe-pequena ou iá quequerê. Para maior aprofundamento a respeito dos cargos sacerdotais no candomblé, ler: Lima $(2003 ; 2010)$.
} 
era de uma rezadeira que ela e sua mãe visitavam na infância. A velha senhora rezava as pessoas com um pedaço de carvão em brasa e um copo com água. Janete acreditava que lembrando este episódio pôde compreender melhor o despertar de sua espiritualidade aos sete anos, quando realizou a primeira cura. Ela revelou-me orgulhosa que um dia seu pai passava muito mal, quando ela pegou o cachimbo de sua mãe e começou a benzê-lo murmurando algumas palavras que ela não se recordava mais. No dia seguinte, o pai havia melhorado completamente e bradava aos quatro cantos que a filha era a responsável pela cura. Após este evento, ela começou a ter visões e a conversar com muitos espíritos que apareciam dançando com saias rodadas brancas.

Aos treze anos, uma colega levou-a numa gira de umbanda pela primeira vez. Ao chegar ao templo ela "recebeu" sua primeira entidade, decidindo assim, aceitar a missão que lhe convinha. Janete narra com riqueza de detalhes as sensações corpóreas deste primeiro transe. Porém, somente aos dezenove anos que ela fez sua camarinha ${ }^{41}$ e iniciou assim sua "carreira" religiosa na umbanda.

Com a morte de sua mãe-de-santo, passou a visitar algumas festas de orixá e acabou ingressando em seu primeiro terreiro de candomblé como abiã. Nesta casa de santo, que também tinha giras de umbanda, fez seu primeiro bori, mas teve profundos aborrecimentos com o sacerdote, que resvalaram para o abalo da vivência religiosa. Isto ocasionou seu gradual afastamento. Como salienta Rita Amaral "apesar da aparente harmonia [...] que a vida e a festa no candomblé expressam, ela não corresponde aos acontecimentos dos bastidores. O conflito no candomblé é permanente" (Amaral, 2002, p. 85).

Durante certo tempo, Janete comandou um centro ${ }^{42}$ de umbanda de um de seus filhos-de-santo. Entretanto, uma de suas entidades ganhou um terreno como "pagamento" por um serviço mágico-religioso, no qual ela pretendia continuar sua prática de umbanda. Essas foram as circunstâncias em que Janete chegou ao barracão de Maricá para procurar ajuda através do jogo de búzios. Para a surpresa dela, descobriu que estava passando por uma "cobrança" de seu orixá:

${ }^{41}$ Camarinha: termo nativo para o ritual iniciático da umbanda. No candomblé em geral, este ritual não apresenta legitimidade. Portanto, quando uma pessoa migra para o candomblé deverá passar pela feitura e ter sua idade ritual contada a partir do zero. Cabe lembrar que, o termo camarinha pode ser utilizado em alguns terreiros de candomblé para se referir ao cômodo ritual no qual é realizada a feitura. Daí a expressão, fazer camarinha difundida entre o povo-de-santo.

${ }^{42} \mathrm{Na}$ umbanda o templo litúrgico geralmente é denominado centro ou terreiro. 
Eu fui lá pra ele botá um jogo pra mim. Aí ele botou um jogo [...] a minha santa tava pedino obrigação. Ele falou assim: Minha filha, você não precisa largá a sua umbanda. Você pode seguir com a sua umbanda. Mas pelo que Iansã tá falando, ela qué fazê 'assentamento'. [...] Mas a minha casa de umbanda eu num vô largá não. (abiã Janete)

Por essa razão, Janete retornou ao candomblé como abiã. Notamos que toda sua trajetória é marcada pela crença numa suposta predestinação. Ela é categórica ao afirmar que não é para qualquer pessoa a vida no santo. Como ela e a abiã Devanilda enfatizaram ao longo de toda a nossa conversa, a postura do paide-santo determinou sobremaneira a entrada efetiva para a religião: "Eu adoro meu pai-de-santo. Gosto muito dele. Ele é uma pessoa que qualquer coisa que você for conversá com ele, você é bem aceito". (abiã Janete)

Vemos que não basta o chamado da divindade, é preciso estar de acordo com as formas de tratamento interpessoal que o terreiro oferece. Nesse sentido, a hierarquia não era vista como algo ruim por si só. As reclamações sempre giravam em torno de como esta relação hierarquizada é experienciada por cada um dos adeptos nas relações cotidianas do templo. Elas reclamaram muito do mau uso de poder e das inúmeras marmotagens encontradas pelos candomblés. Por conseguinte, as formas de acolhimento nos terreiros reaparecem, portanto, como um fator decisivo para o ingresso tanto de Janete quanto da abiã Devanilda:

Meu pai-de-santo é um amô de pessoa. Ele é humilde, ele é generoso, ele é amigo. O que é muito difícil! Ele tem o poder. É como se você tivesse num lugar que Deus abaixa, que Deus chegasse e fosse igual ao seu irmão. Ele tem todo o poder do mundo de fazê tudo que ele pudé, que ele quisé, e ele não faz. Ele é simplesmente seu amigo. Você se sente à vontade. (abiã Devanilda)

O caso da abiã Devanilda de 33 anos era um pouco inusitado, pois nutria uma simpatia pelo candomblé sem estar decidida pela iniciação. Na época de nossa entrevista, ela ponderava o enorme comprometimento que o candomblé exige e, portanto, ainda não se sentia preparada para tal. Mas era nítido seu enorme encanto pela liturgia da religião. Sua narrativa pontuava a todo instante a beleza das vestes, das danças e dos cerimoniais que já teria presenciado: "Eu acho muito lindo. Mas tipo uma 'vitrine'. Só de vê! De entrá eu já acho muito complicado. Acho muito difícil”. (abiã Devanilda)

Durante toda sua infância, Devanilda frequentou a igreja católica e passou por muitos de seus sacramentos, como o batismo, o catecismo, a crisma e a consagração. Em sua opinião, o ingresso na umbanda foi uma decisão tomada 
pelo coração, ao contrário da igreja católica que teria sido mais uma "imposição" cultural. Com essa conclusão, passou a botar roupa na umbanda na companhia de sua mãe carnal, que sempre fora umbandista. Durante seus dez anos acompanhando a mãe, jamais teve uma experiência de transe com alguma entidade ou orixá. No candomblé, ela também ainda não havia passado pela experiência contundente de bolar. Talvez por isso, ainda não apresentasse uma decisão tão firme no tocante a passar pela feitura. Conforme já citei, a manifestação da divindade é sempre uma expectativa bastante angustiante para aqueles abiãs que ainda não a vivenciaram. Parecia que este era o estágio que Devanilda vivenciava quando nos conhecemos:

Porque querê eu quero. Eu acho bonito! Apesá de eu achá que é muita responsabilidade. Eu não sei se eu vô consegui dá conta. [...] E tem a história de: ah, se você não qué vai ficá pelejando, pelejando e numa hora você vai bater no barracão, você vai 'bolá' e ficá lá! [...] Você só vai sair dali já careca, já raspada! [...] Então, é quase que não é uma escolha. Se é, vai tê que sê, e ficá, e pronto! Se não é, nem bola. (abiã Devanilda)

Entrementes, era o jogo de búzios que parecia sustentar a decisão de Devanilda em ingressar efetivamente num roça de candomblé. Afinal, a força simbólica do oráculo manipulado pelo pai-de-santo, age com enorme intensidade sobre a subjetividade de seus filhos-de-santo. Era através das palavras do sacerdote que o "chamado" dos orixás chegava até esta abiã. Conforme Póvoas (2006) esclarece "é no quarto de consulta que se lê a fala do orixá", para que "tanto o filho-de-santo quanto estranhos se esclareçam no que diz respeito a sua identidade" (Póvoas, 2006, p. 218-219). Porém, percebi que a abiã Devanilda parecia confiar a uma manifestação sagrada mais "concreta" sua decisão final de passar pela feitura.

Por outro lado, há casos como o da abiã Vanise de 27 anos, que teve a experiência de sentir o chamado do orixá no próprio corpo por diversas vezes. E foi justamente este fato que a impulsionou na busca por uma oportunidade de satisfazer o que, embora para ela seja uma escolha, configura-se também como uma espécie de predestinação. Em sua biografia, o ponto inicial é o terreiro de umbanda que frequentava junto com os pais desde a infância. Conforme ela ressalta, neste mesmo templo de umbanda, foi "convocada" pela espiritualidade para colocar roupa e desenvolver sua mediunidade, junto com o irmão consanguíneo. Até então, nunca ouvira falar sobre o candomblé. 
Num momento posterior, o sacerdote de seu primeiro templo se iniciou no candomblé - o que ela atribuiu uma responsabilidade de estimular o lado espiritual dos filhos-de-santo que começaram a "passar mal". Assim, Vanise "bolou" pela primeira vez durante uma reunião de médiuns. Ao consultar o jogo de búzios de seu pai-de-santo na época, descobriu sua necessidade de feitura. Naquele momento, até mesmo pela pouca idade, passara apenas pelo ritual de bori para tentar arrefecer a vontade da sua divindade. Sua primeira compreensão de que era uma abiã data desta circunstância.

Todavia, por insatisfações diversas, migrou para o terreiro de seu avô-desanto, que também praticava candomblé e umbanda. Vanise revela como num desabafo, que os longos anos "trabalhando" com suas entidades na umbanda não satisfizeram suas demandas de um cuidado mais personalizado. Segundo ela, a visão doutrinária da caridade faz com que o religioso esteja mais voltado para os outros do que para as próprias necessidades espirituais. Além do que, o número crescente de filhos-de-santo fazia com que a relação interpessoal com o sacerdote se tornasse por demais burocratizada. Da mesma forma, ela identificou também, uma conduta de favorecimentos e preferências por alguns membros. Por isso, Vanise resolveu optar pelo afastamento do terreiro e da religião por uns três anos. Neste período, casou e teve uma filha. Segundo ela explicou, ser casada com uma pessoa que não gosta da religião dificulta ainda mais a mulher de dar prosseguimento a sua vida religiosa. A presença de filhos pequenos também torna mais difícil poder ser uma abiã no candomblé, segundo ela.

Foi somente quando novas aflições (cf. Fry, 1975) surgiram em sua vida, que ela decidiu buscar ajuda no terreiro de mãe Dora, já que esta havia sido mãede-santo de seus dois sacerdotes anteriores. Portanto, Vanise já havia tido um contato prévio, do qual restara a impressão desta sacerdotisa ter uma conduta diferencial entre os praticantes do candomblé. Ela descreve mãe Dora como uma referência de firmeza e seriedade na prática ritual. Isto posto, seu reencontro com a tal mãe-de-santo, inicialmente como "cliente", converteu-se numa escolha por dar continuidade ao seu abianato:

Foi o candomblé que me acolheu quando eu precisei [...] que me mostrou um caminho, uma direção. [...] O candomblé é muito pessoal. Você cuida de você, do seu caminho, da sua cabeça. [...] Eu não escolhi o candomblé. Eu fui escolhida! Eu acho que não é pra todo mundo. É para os escolhidos. [...] Quando eu cheguei na mãe Dora eu criei raiz ali na mesma hora. [...] Eu aprendi até de uma forma 
muito ruim, que quando você escolhe um caminho diferente que não é o seu, você tem que arcar com as consequências daquilo. Isso é muito perigoso! (abiã Vanise)

Depois de um tempo frequentando o terreiro escondida do marido, a crescente "cobrança" do orixá fez com que Vanise tomasse coragem de assumir sua vida religiosa. Mãe Dora exigiu que o marido da moça fosse até o barracão para uma conversa na qual colocariam às claras tudo o que ocorreria com o advento da feitura. Felizmente, comemorou a abiã, tudo correu bem. Acompanhei a abiã Vanise no terreiro de mãe Dora - onde inclusive a conheci - até a véspera de sua feitura. Dois dias antes de sua reclusão ritual ela esteve em minha casa para formalizarmos nossa entrevista em 2016. Neste mesmo dia, ela veio acompanhada da abiã Priscila, que também era sua amiga íntima, além de irmã-de-santo.

A abiã Priscila de 23 anos teve uma infância bastante eclética no quesito religioso. A maior parte dos parentes paternos era evangélica, mas a avó materna já havia sido católica, evangélica e umbandista. No entanto, sua primeira vivência religiosa mais intensa foi na igreja evangélica, mas sem jamais se converter. Aos onze anos via com muita naturalidade as visitas à igreja evangélica.

Porém, foi somente aos treze anos que conheceu na escola uma menina que retornou das férias com a cabeça totalmente raspada. Ela lembra que na época, isto causou um enorme burburinho na escola. Sua amiga Juliana havia sido feita no candomblé durante o recesso escolar. Priscila ficou muito assustada e curiosa ao ver sua colega de classe chegar à escola careca, usando roupas brancas, colares e insígnias amarradas nos braços. Pela forte intolerância e discriminação, a iaô revelou apenas para os colegas mais íntimos o que realmente havia se passado. Contudo, foi a curiosidade a respeito do acontecido que levou Priscila a visitar o barracão da coleguinha após a saída do turno escolar.

No estreitamento desta amizade, as visitas à residência da avó de Juliana que era a mãe-de-santo - acabaram por estimular a curiosidade e a atração de Priscila pelo universo religioso em questão: "Fui entrando como coleguinha da escola e virei filha da casa de axé. Achei tudo aquilo incrível! Aquelas roupas, aquela coisa toda!". Cada vez que almoçavam juntas, Priscila ia se familiarizando com o dia a dia do terreiro. Mãe Sonia era feita no candomblé, mas também cultuava umbanda no seu barracão, que era localizado em seu próprio quintal.

Foi assim que Priscila se apaixonou pela religião e começou a frequentar escondida às giras de umbanda. Seus pais não aceitavam aquela situação, mas os 
membros do terreiro ajudavam a menina guardando seus objetos rituais e lavando suas vestes religiosas. Na verdade, a mãe de Priscila, depois de um tempo, passou a acobertar o fato. Mesmo com a enorme confusão quando o pai descobriu tudo, ela permaneceu no templo até os dezoito anos. Ela lembra as imagens de pessoas bolando e de alguns rituais de candomblé sendo realizados, embora sua aproximação maior tenha sido apenas com a parte de umbanda. Foi neste período que Priscila desenvolveu sua mediunidade e tomou gosto pelas religiões de matrizes africanas. Com a crescente pressão dos pais e o fim da fase escolar, ela acabou se distanciando de tudo.

Depois de uns três anos afastada, sua amiga Vanise lhe convida para fazerem um jogo de búzios no terreiro de mãe Dora. Como sua vida figurava bastante confusa, pois "estava em épocas bastante difíceis [...] sem emprego, sem namorado [...] perdida!", Priscila resolveu apostar numa reaproximação da religião. Nessa nova tentativa ela encontrou todo o acolhimento que precisava na ocasião. Há quatro anos tornara-se abiã pela primeira vez. A cada dia foi se encantando mais pela ritualística e desfazendo seus preconceitos em relação à religião. A ajuda recebida no templo implicou numa profunda afeição pelo candomblé corporificado na pessoa da sacerdotisa:

Eu entrei no candomblé por causa da Dora. Não foi por causa do candomblé. [...] Tenho uma gratidão eterna com essa mulher. Então, vô ficá aqui. [...] O candomblé me escolheu. Eu me senti abraçada pelo candomblé no momento que eu mais precisei. Então esse aqui é o meu caminho! [...] Nossa, uma das coisas mais lindas que eu já vi na minha vida! Muito lindo! Muito fascinante! (abiã Priscila)

Segundo ela, o estreitamento dos vínculos com o candomblé foi aos poucos provocando mudanças na sua vida. Além de iniciar um namoro, conseguiu emprego no comércio. Mesmo não havendo culto de umbanda no terreiro de mãe Dora, Priscila foi descobrindo novas formas de ajudar as pessoas de acordo com este novo estilo religioso. Seu namorado acabou por se aproximar e tornara-se abiã neste terreiro também. No momento de nossa entrevista, Priscila já havia passado pela a experiência de bolar, mas ainda não tinha perspectiva de quando realizaria sua feitura.

De fato, a generosidade de mãe Dora era um traço marcante de sua personalidade. Posso considerá-la como minha informante privilegiada ao longo desses quatro anos de pesquisa. Através dela que conheci também a abiã Jurema 
de 58 anos, pertencente a outro barracão de candomblé na zona oeste/RJ.

Estávamos num evento de cultura afro-brasileira quando vi Jurema cumprimentar mãe Dora com toda a etiqueta litúrgica própria do candomblé. A sacerdotisa de Jurema era uma das organizadoras do evento. Em alguns minutos de conversa - elas se conheciam de outras circunstâncias religiosas - mãe Dora logo precipitou-se em apresentá-la como uma ótima abiã para fazer parte da pesquisa. Daí em diante nunca mais deixamos de nos comunicar.

Jurema havia tido seu primeiro contato com o candomblé na infância, quando sua mãe muito doente procurou um terreiro de modalidade Angola. Elas passaram por alguns procedimentos rituais como ebós e bori, mas não realizaram a feitura. Na ocasião, ambas ingressaram para a casa como abiãs. No seu relato, fica claro também o fascínio inicial pela dimensão estética da religião, com suas festas que conjugam canto e dança. Porém, Jurema e sua mãe se afastaram do templo ao descobrir que a mãe-de-santo aliciava várias das filhas-de-santo. Numa ocasião bastante desagradável, elas descobriram que a sacerdotisa ficava escondida espiando os adeptos enquanto tomavam banho no barracão. Contudo, ela faz questão de destacar que a decepção não foi com a religião em si, mas com a postura equivocada da líder religiosa.

No tocante à biografia de Jurema, percebi que todas as vezes que tentou ingressar numa forma religiosa, foi através de um membro de sua família. $\mathrm{Na}$ segunda incursão, Jurema frequentou o catolicismo com seu falecido filho que tinha imensa afinidade com a igreja católica. Após a morte do menino, ela começou a buscar um apoio emocional para sua dor através do espiritismo. Durante um bom tempo percorreu centros espíritas em busca de psicografias do filho que havia morrido de câncer. Mesmo contente por ter atingido seu objetivo, ela pondera que as reuniões espíritas deixavam-na numa profunda melancolia.

Entretanto, nesta mesma época, o neto começou a apresentar sintomas depressivos. Por esta razão, Jurema e sua filha resolveram buscar uma ajuda mais imediata no candomblé, pois "foi uma porta que se abriu e a solução mais rápida". Ela levou o neto para fazer um jogo de búzios, que desembocou em vários procedimentos rituais e na consequente iniciação dele com ogã. Jurema retomou desta maneira a convivência com cotidiano do terreiro, mas sempre para acompanhar o neto menor de idade. Com isso, ela descreve que passou a sentir uma alegria que não encontrava nos centros espíritas que vinha frequentando 
desde o falecimento do filho. Segundo ela, foi com o candomblé que conseguiu solucionar os problemas espirituais do neto e a profunda insatisfação interior que possuía:

Eu sempre gostei dos atabaques. Aquela coisa... eu sempre gostei! Eu voltei por causa da minha filha e do meu neto. [...] O louvor ao orixá me dá energia, me deixa feliz. Eu venho satisfeita! [...] Eu fui pro candomblé porque realmente louvá o orixá pra mim é uma coisa maravilhosa. É muito bonito mesmo, me emociona! Eu venho bem. Eu venho feliz. Eu venho pra cima! (abiã Jurema)

Sua retomada do abianato depois de tantos anos apresentou diversas dificuldades pela idade mais avançada, mas a seriedade e o acolhimento da sacerdotisa fizeram toda a diferença para sua decisão. Inicialmente, estava presente apenas na condição de acompanhante. Com o tempo, percebeu que era grande sua satisfação na convivência no terreiro e, como já estava sempre ali, concluiu que não havia motivos para não ingressar efetivamente na religião.

No entanto, muitas vezes ao longo de nossas conversas ela dizia que "não é qualquer pessoa que pode ser do candomblé". Segundo ela, o "trabalho" no terreiro e as exigências são bastante difíceis de coadunar com a vida escolar e profissional dos adeptos. Na época que participou da pesquisa, Jurema estava desempregada e vivia com a filha e o neto.

Embora fosse mais velha, ela não via como incômodo o fato de estar em posição subalterna mediante pessoas mais novas, porém superiores em idade iniciática. Até o momento de nossa entrevista, Jurema ainda não havia bolado, além de revelar não ter a menor pretensão de chegar logo o dia de sua feitura. Ao ingressar como membro da comunidade litúrgica, tinha na melhora do neto um grande alicerce para sua permanência no culto. No seu discurso de abiã, podemos perceber também sua consciência a respeito do prazer sentido pelo neto no convívio com a liturgia típica do candomblé:

Um dia ele nos acompanhou e ele se encantou. Vamos dizer assim, com os atabaques, com a macumba ${ }^{43} \mathrm{em}$ si. Ele achou aquilo muito bonito. Uma energia muito boa. E não quis mais sair. Tanto é que a mãe saiu da religião e ele continuou. (abiã Jurema)

Acreditando na predestinação do neto para o culto aos orixás, ela passou

\footnotetext{
${ }^{43} \mathrm{O}$ termo macumba aparece aqui como uma forma genérica de se referir à festa ritual de matrizes africanas. Conforme aponta Carmem Opipari (2009), este termo pode ser empregado pelos religiosos para englobar de forma imbricada as modalidades do candomblé e da umbanda de maneira "natural".
} 
um bom tempo acompanhando-o, até que finalmente foi suspensa como equede ${ }^{44}$ durante uma festividade. Ela cumpriu o ciclo iniciático completo, pois foi abiã , depois suspensa e por final confirmada. Daí em diante se comprometeu cada vez mais com a religião, tanto quanto o seu neto inicialmente. Após o término de meu trabalho de campo, ao longo da escrita deste estudo, recebi a notícia de que Jurema e seu neto estavam afastados do terreiro. Mas não consegui agendar um encontro para conversarmos sobre este afastamento. Em breve conversa telefônica com ela, percebi sua profunda insatisfação em relação à sobreposição dos interesses materiais nas práticas religiosas de seu terreiro.

As histórias de transição e afastamento dos adeptos nas casas de axé são cada vez mais recorrentes e geram assunto para prolongadas rodas de conversa e especulações entre o povo-de-santo. Nessas idas e vindas dos religiosos, toda uma fabulação a respeito da competência ritual dos sacerdotes parece também estar em jogo. Numa dessas conversas no terreiro de pai Carlito, um ebôme chamado Ronaldo me falou de dois abiãs, que haviam se afastado de seus respectivos terreiros por inúmeras divergências. Logo que soube da história dos abiãs Afonsinho e Odete, insisti para que Ronaldo me apresentasse a eles. O instinto etnográfico ávido por casos contrastivos imediatamente me impulsionou a ir ao encontro desses abiãs.

Na companhia de Ronaldo, no ano de 2015 comecei a visitar outro terreiro na zona oeste/RJ, no qual Afonsinho estava iniciando sua experiência de abianato. Mas nossa entrevista formal aconteceu em minha casa apenas um ano depois, quando o rapaz já havia saído deste terreiro para dar continuidade ao seu abianato na mesma casa de santo que seu namorado frequentava em Itaguaí. Portanto, observei sua atuação apenas no barracão onde ele botou roupa pela primeira vez.

Afonsinho é militar e desde pequeno teve uma formação completamente católica. Quando completou treze anos, conheceu um amigo que lhe fez um convite inusitado, segundo sua concepção cristã até então: organizar encontros

\footnotetext{
${ }^{44}$ A cerimônia de suspensão de equede é similar à suspensão do ogã. Um orixá manifestado leva a religiosa até uma cadeira na qual os ogãs a suspendem literalmente, num cerimonial específico de cada terreiro. A partir daquele dia, a religiosa será reconhecida como equede por todos os membros da comunidade litúrgica. Porém, deverá concluir seu pertencimento efetivo e eterno através de um recolhimento ritual conhecido com confirmação de equede. Este é um cargo ritual dado apenas às mulheres que não são passíveis de transe. Sua função no culto será zelar pelos filhos-de-santo no momento do transe. Para maiores informações acerca da trajetória religiosa de uma equede, ver o estudo de Evangelista (2015).
} 
para estudar o candomblé. Naquele momento, Afonsinho disse achar um absurdo, pois “aquilo não era coisas de Deus". No entanto, acreditando poder "resgatar" o amigo daquele "desvio" religioso, aceitou o convite.

Para sua grande surpresa, os finais de semana de estudo lhe ajudaram a compreender a riqueza e a complexidade das religiões afro-brasileiras. Resultado: seu primeiro estágio de encanto por estas modalidades de religiosidade se deram curiosamente pelo estudo teórico. Quando o rapaz resolveu revelar a aventura intelectual juvenil para sua mãe, descobriu que ela também estava frequentando um terreiro de umbanda secretamente. Então, juntos passaram a visitar outros terreiros. Contudo, os dois possuíam maiores ressalvas quanto a se aprofundar no candomblé, principalmente pela questão da imolação animal.

Como já ressaltei anteriormente, uma das primeiras preocupações de um novo adepto das religiões de matrizes africanas, costuma ser a descoberta de seu orixá protetor e da sua condição de entrar em transe ou não. Neste quesito, com Afonsinho não foi diferente. Porém, seu primeiro jogo de búzios foi realizado por uma preta-velha ${ }^{45}$ numa gira de umbanda. Pelo contato com esta entidade, ele descobriu seu orixá protetor e, para sua própria surpresa, uma suposta herança espiritual. Com o impacto da descoberta de sua "missão" religiosa, ele desabafou com a mãe e acabou descobrindo que seu avô havia sido um famoso sacerdote afro-brasileiro em Minas Gerais. A partir daí, frequentou por mais dois anos as giras de umbanda neste terreiro. Acreditando que um dos médiuns estava usando a própria entidade para obter benefícios materiais dos visitantes, Afonsinho e sua mãe também se afastaram.

Num intervalo de tempo no qual ele passou num concurso e ficou na Bahia, teve a oportunidade de conhecer alguns terreiros por lá e perceber a profunda diferença em relação ao que estava habituado. No retorno ao Rio, começou a frequentar paralelamente um templo de umbanda e outro de candomblé na zona oeste/ RJ, que um amigo havia apresentado. Mas acabou ficando apenas no segundo. Foi neste barracão que sua experiência de abianato

\footnotetext{
${ }^{45}$ Os chamados pretos-velhos compõem uma categoria de entidades que se manifestam nas giras de umbanda. São compreendidos pelos nativos como espíritos de africanos que foram escravizados no Brasil. Como salientou Maggie (1975), nesses rituais opera um "código do santo" que possibilita uma inversão ritual da posição inferior que estes seres ocuparam na sociedade. Nas giras de umbanda eles passam para um status de alto prestígio. Para maior aprofundamento ver os estudos de Maggie (1975); Magnani (1991); Birman (1985)
} 
começou.

Nas oportunidades em que encontrei o abiã Afonsinho foi exatamente neste templo de candomblé, mas que também tocava umbanda. Sua decisão de colocar roupa ali visava também esta complementaridade religiosa. Todavia, na época que reencontrei Afonsinho para a entrevista, ele havia retornado para o terreiro de Itaguaí, que agora estava implantando também o candomblé. Sua felicidade era intensa, pois percebia que finalmente, aos 25 anos, estava no caminho certo para desenvolver o que considerava um dom espiritual:

Acho que a primeira vez que eu fui numa casa de candomblé achei tudo muito novo e achei muito impressionante! [...] Eu sinto vivo toda vez que eu arrepio com o batuque. [...] Eu vejo como um dom às vezes. Isso são meus ancestrais. Eu vi que não tinha pra onde correr, que aquilo ali já era pra eu ir, né? Já vem comigo, já carrego comigo. [...] Um dom, né? Quem tem, tem, quem não tem, sente inveja. [...] Eu acredito muito naquilo que eu tenho, naquilo que eu frequento. (abiã Afonsinho)

A descoberta de uma suposta herança espiritual parece ter sido também o argumento que levou a abiã Odete a iniciar sua "carreira" religiosa no candomblé desde tenra idade, conforme deixa transparecer na narrativa de sua biografia. Em 2015, quando o ebôme Ronaldo nos apresentou, ela estava com 26 anos, mas permanecia afastada dos terreiros há algum tempo. Nossa entrevista formal foi realizada apenas em 2016 na minha residência, em um de seus dias de folga da loja de roupas de bebê em que ela trabalhava.

Odete me contou que sua família paterna sempre foi praticante das religiões de matrizes africanas. A tia de seu pai tinha um terreiro de umbanda, no qual ela tivera seu primeiro contato quando criança. A lembrança de seu desconforto e nervosismo neste episódio é explicada hoje como o aflorar de sua "essência" espiritual. Porém, foi apenas aos 19 anos que "colocou roupa" efetivamente num centro de umbanda que tocava Angola uma vez ao ano. Mas foi somente com o falecimento de sua avó que precisou procurar uma ajuda no candomblé.

Logo após a morte desta avó que era feita, começaram a aparecer diversas erupções cutâneas que os tratamentos médicos não conseguiam solucionar. Por esta razão Odete buscou o jogo de búzios num terreiro da modalidade Queto. Nesta ocasião ela compreendeu que sua aflição estava relacionada a uma herança espiritual familiar. Sua bisavó e avó teriam sido ambas feitas, mas sua mãe por negar esta suposta herança, acabou por deixá-la para Odete. Portanto, os búzios 
indicavam que a única solução seria a feitura. Por esta razão a jovem ingressou na sua experiência de abianato. No decurso de toda nossa conversa ela reforçava a diferença entre as pessoas que entram na religião por uma espécie de deslumbre, e outras que como ela, possuem uma necessidade espiritual compreendida como autêntica:

Muitas pessoas não conhecem e acham bonito também. As pessoas não tão indo pela essência e necessidade. Tão indo pela, "ai, que lindo! Que roupa linda! Que festa linda!" [...] Tem uns que vão por amor ao orixá, outros vão pela dor e pela necessidade. Eu fui pela necessidade. Eu não fui porque eu achei bonito. Tive uma necessidade, um problema espiritual [...] Um dia eu penso sim. Eu penso em me acertar na vida espiritual sim. (abia Odete)

A realização de um bori para tentar prorrogar a feitura, fez com que ela passasse dois anos e meio neste terreiro. Com a pressão constante do pai-de-santo para agendar a iniciação, ela acabou se afastando depois de um desgastante aborrecimento. Ele já havia inclusive informado o valor de cinco mil reais para realizar sua feitura, mas a insegurança de Odete crescia cada vez mais. Isto posto, a jovem passou por um período de muitas dificuldades espirituais, emocionais, profissionais e materiais. Como ela relembrou: "Eu fiquei maluca! Eu não podia vê o sol. Eu dei santo ${ }^{46}$ na rua [...] no meio da praça na Pedra de Guaratiba".

Depois de sete meses desorientada e "passando mal" intermitentemente, ela resolveu fazer outro jogo de búzios com um segundo pai-de-santo. No entanto, descobrindo os erros rituais anteriores que causaram tamanho desequilíbrio, Odete tentou por um ano dar continuidade ao seu abianato novamente. Infelizmente, sua segunda tentativa de se acertar na vida religiosa foi frustrada devido ao mesmo tipo de conduta por parte da liderança espiritual.

Ao contrário da maioria dos abiãs do grupo estudado, quando conversamos ela estava bastante descrente da possibilidade de encontrar um acolhimento autêntico nos terreiros de hoje. Para esta abiã, a "essência" da religião está bastante corrompida pelos interesses financeiros de alguns líderes religiosos. Entretanto, como a abiã Patrícia, ela permanece acreditando na força transmitida pelos orixás, mas não vislumbra um horizonte positivo ao encarar a postura questionável de muitos sacerdotes:

O candomblé hoje em dia tá um comércio. Quanto mais bonito tivé, mais pessoas

\footnotetext{
${ }^{46}$ As expressões dar santo ou virar no santo são usadas correntemente pelos religiosos para
} indicar o estado de transe de orixá. 
vai atraí. Então aquilo ali tudo tem que tá bem bonito. Hoje em dia eles não tão ligando muito pra essência das pessoas. O pai-de-santo tá visando festividade pra chamá a atenção de clientes também, né? Que aí os clientes também vão assistir, vão vê. Quando ele vê aquela festividade toda, a beleza toda, acaba se encantando e vindo noutro dia jogá. (abiã Odete)

Essas foram algumas das tramas de encantos e desencantos do grupo de abiãs que observei nos últimos anos. Neste breve relato de suas biografias, apresentei um pouco da maneira como eles conheceram o candomblé e ingressaram efetivamente no abianato. A busca por um acolhimento permeou o discurso de todos eles. Outro fator que ganha destaque é maneira como o apelo estético da ritualística dos candomblés é capaz de despertar a curiosidade e a atração em seus visitantes. De modo geral, a percepção da dimensão "espetacular" do candomblé foi revelada por todos os entrevistados. Eles mesmos conferem nuances semânticas distintas para a percepção da "teatralidade" contida nas performances apresentadas nas festividades em louvor aos orixás, como veremos ao longo do estudo.

A "espetacularidade" dos rituais públicos do candomblé ora figura com um caráter de beleza - o que atrai e provoca prazer estético -, ora como sinônimo de perda da "essência", na opinião de alguns nativos. Os próprios religiosos parecem manipular um código interno que detecta estas distintas gradações semânticas da flagrante "espetacularidade" que constitui a roda de santo.

Desta maneira, entre uma aflição e outra e passando pelo barracão, das festas ao quarto de jogo de búzios, boa parte dos visitantes e "clientes" inicia sua "carreira" religiosa através da experiência do abianato.

\title{
2.2
}

\section{A mise em scène de mãe Dora}

\begin{abstract}
Meu filho, é uma escolha! Mas eu fui escolhida pelo candomblé! [...] Eu num consigo pensá na minha existência sem o candomblé. Ele também é minha família, né? Ele é minha raiz, minha existência, minha forma de vida, minha lembrança, minha direção. Porque sem isso eu num sô nada, nem ninguém. Ele faz parte da minha personalidade, da minha pessoa! (mãe Dora)
\end{abstract}

A lembrança de nosso primeiro encontro ainda é nítida na minha memória. Ambos éramos alunos de um curso de extensão sobre candomblé em agosto de 
2013 e, como nos confidenciamos mutuamente a posteriori, a experiência não supriu nossas expectativas. Porém, as longas viagens semanais até o bairro de Botafogo, compensaram bastante, tanto pela informante privilegiada que adquiri, quanto pela amizade que se construiu ao longo do tempo. Mãe Dora, como é chamada por todos em seu terreiro na zona oeste do Rio de Janeiro, recebeu-me de braços abertos desde o início de nosso primeiro encontro. Sua personalidade histriônica e carismática, logo chamou minha atenção nas aulas. Por outro lado, segundo ela, minhas colocações "entre uma cochilada e outra" também despertaram nela um interesse pela minha pessoa. Entre o povo-de-santo esta empatia é demonstrada com o uso da expressão "meu santo bateu com seu".

Ao término do referido curso no mês de outubro de 2013, mãe Dora fez um convite a todos da turma para um singelo orô $^{47}$ que realizaria em seu terreiro. Sempre cautelosa, tratou logo de avisar que não era candomblé festa, pois tratavase apenas de um orô para o orixá, como fazia questão de frisar. Na ocasião, ela disponibilizou para todos do grupo seus telefones e endereço de e-mail. Imediatamente, pensei que esta seria uma excelente oportunidade para estreitar nosso contato, já que havia convidado-a para participar da pesquisa. Ela realmente era uma figura de destaque nas aulas, sempre trazendo em gestos amplos e imponente expressão vocal os inúmeros causos de clientes ${ }^{48}$ e filhos-de-santo, que frequentavam o terreiro que ela herdara de sua falecida mãe. Quando a conheci, ela tinha quarenta anos de iniciada no candomblé e orgulhava-se de ser uma senhora de sessenta anos com muita disposição para tocar o barracão e a própria casa todos os dias, pois como sempre explica:

O candomblé tem uma incidência física, meu filho! [...] Ele é um conjunto! Trabalho físico... danças tribais... um conjunto de andar e se dar! Eu cuido da minha casa e do candomblé. Eu não tenho empregada. Nem faço dos filhos-desanto empregados. Você tá entendendo? Eu me desdobro aqui e lá. [...] Eu não posso ser dependente. $\mathrm{O}$ dia que eu tiver que ser exclusivamente dependente eu paro. (mãe Dora)

Sendo aposentada, mãe Dora passa maior parte do tempo atendendo

\footnotetext{
${ }^{47}$ Orô: expressão utilizada pelo povo-de-santo para designar a imolação sacrificial aos orixás ou, de forma generalizada, para indicar qualquer tipo de cerimonial litúrgico. Seu uso pode estar relacionado também à ideia de segredo.

${ }^{48} \mathrm{O}$ termo cliente é usado para identificar todas as pessoas que usufruem dos serviços rituais pagos que o candomblé oferece para a sociedade. Como afirma Prandi (1991; 1996; 2005) a clientela é parte fundamental para o funcionamento do terreiro, pois além de auxiliarem na manutenção material do mesmo, representam significativa fonte de prestígio e novos filhos-de-santo.
} 
centenas de clientes - do Brasil e do exterior - e realizando serviços rituais para seus filhos-de-santo ou de qualquer suplicante que bata em sua porta a qualquer horário do dia ou da noite, como ela sempre lembra: "cansei de tá pronta pra saí, imbicando o carro no portão e escuto:' Doooraaa! Mãe Dooraa!' Aí já sei que babou tudo. Acabo voltando". São muitos os relatos do marido e da filha única ambos não iniciados na religião - a respeito da falta de discernimento de algumas pessoas que buscam ajuda a qualquer dia ou horário. Para mãe Dora ajudar é imprescindível na sua missão, mesmo que não seja filho-de-santo ou cliente. Por isso tornou-se uma referência para as emergências da vizinhança.

No dia combinado para o orô do santo, fui finalmente conhecer seu terreiro. Na verdade, mãe Dora mora em uma vila de casas, sendo que num mesmo terreno, sua residência está conjugada ao que seria o barracão. No ano de 1965 sua falecida mãe havia fundado ali seu candomblé em meio a um vasto matagal, que com o passar dos anos foi todo ocupado por dezenas de casas e estabelecimentos comerciais. Portanto, sua casa de axé está incrustada no interior de uma área urbana e residencial. Do lado de fora da casa, não há nenhum tipo de sinal ou emblema que indique ali a existência de um terreiro de candomblé.

$\mathrm{Na}$ entrada, um enorme quintal onde seus cachorros correm o tempo todo e alguns amigos, clientes ou filhos-de-santo estacionam seus carros. Circundando a área, um jardim sempre muito bem cuidado, faz às vezes também de bosque sagrado de onde retira grande quantidade de folhas ritualísticas. No centro do quintal, um jogo de várias mesas com cadeiras que ficam constantemente ali dispostas com revistas, jornais, copos de água, xícaras de café e cinzeiros. Nesse espaço - uma espécie de hall do barracão - há sempre gente, fumando, tagarelando, chorando ou louvando.

Frequentemente, devido ao calor tremendo que o salão interno possui os chamados orôs públicos são realizados nesse espaço. Como várias vezes ela me explicou, depois da morte de sua mãe, ela fizera diversas mudanças estéticas, arquitetônicas e de funcionamento na casa de santo como um todo. Mudou a pintura do muro, desfez quartinhos de santo $^{49}$ que ficavam expostos no quintal e inclusive guardou os atabaques definitivamente. Hoje, suas preocupações eram duas: não incomodar a vizinhança e fechar-se para o que era fundamental no

\footnotetext{
${ }^{49}$ Referência a pequenas construções para guardar as insígnias dos orixás.
} 
candomblé: os orixás. Ela sempre me dizia que com o tempo, as coisas na religião foram virando show. Então, definitivamente posicionava-se na contramão disto. Sua prioridade era sempre o orixá. E a ajuda que o suplicante necessita. Como ela insistia: "é o orixá que dá o show aqui!".

Ao participar do orô daquela manhã de outubro de 2013 - cantado e rezado ao som de um agudo e brando toque de agogô - percebi a verdadeira excepcionalidade da maneira como mãe Dora pensava e vivia o candomblé nos dias de hoje. Embora no momento que a conheci ela não possuísse nenhuma reserva de abiãs, acolheu-me de braços abertos como fazia com todos que batiam à sua porta.

Minha primeira entrevista formal em meu percurso etnográfico ocorreu justamente com ela dias depois. Aliás, as reminiscências desta tarde também são vivas em mim. Quando cheguei no horário marcado, tive a imensa surpresa de ser recebido por uma senhora que, ao contrário do que eu esperava, estava despida de todas as suas insígnias sacerdotais. Recebeu-se na simplicidade de um vestido estampando de viscose na mesa de sua sala. Água, café e muita fumaça de cigarro.

Nesta recepção despojada e acolhedora, anunciava-se um estilo próprio de repensar os códigos padronizados do candomblé e a surpreendente generosidade com que se doaria ao meu projeto. Ao longo de nossas incontáveis conversas no seu quintal madrugadas adentro nos últimos anos, à base de muitas garrafas de café e dezenas de maços de cigarro fumados por ela compulsivamente, tive a certeza de que estava diante de um rico caso destoante do que encontrava na maioria dos terreiros que visitara até então.

Com o tempo, as abiãs Vanise e Priscila chegaram ao seu terreiro.

\section{3}

\section{A mise em scène de pai Carlito}

\footnotetext{
Meu primeiro contato com o candomblé, ele se deu por curiosidade [...] Meu sentimento logicamente foi mudando e eu cada vez mais fui buscando. Até que chegou o momento que eu decidi me iniciar. [...] Eu não fiz santo no candomblé por obrigação. Eu fiz por amor! Por necessidade e querer buscar conhecimento e... de podê dá mais aos meus filhos-de-santo e de sê um sacerdote melhor. Mais completo, vamos dizer assim. Com outros conhecimentos. Eu escolhi o candomblé! O candomblé foi uma escolha! (pai Carlito)
} 
Um colega de oficinas sobre cultura afro-brasileira havia me apresentado a ele com recomendações múltiplas de seu excelente jogo de búzios e sua humildade na conduta sacerdotal. Frequentei seu terreiro na zona oeste do Rio de Janeiro por um bom tempo. Da mesma maneira, inúmeras haviam sido nossas conversas sobre os dogmas e os rumos da religião. No entanto, nossa entrevista formal nunca se concretizava, pois sua agenda estava sempre cheia e quando eu menos esperava, ele "escorregava".

Naquela noite quente de outubro de 2013, ao término de uma reunião de médiuns no terreiro, consegui finalmente cercar pai Carlito num momento de relaxamento e convencê-lo da realização da entrevista, que ele me prometera há tanto tempo. Já havíamos desmarcado várias vezes, embora ele tenha sido o primeiro sacerdote que conheci mais intimamente nesse percurso etnográfico dos últimos quatro anos. Nesse ínterim, observei surpreendido que o pai-de-santo pegou uma caneca de cerveja - afinal, era o término de seu "expediente" diário sacerdotal - e o celular, que nos primeiros momentos da entrevista não parava de tocar. Num cômodo reservado do terreiro do qual ouvíamos a algazarra infantil no quintal, finalmente realizei a tão desejada entrevista.

José Carlos, chamado carinhosamente por todos de pai Carlito, tinha quarenta e um anos de idade e desde os quinze, por decisão própria, frequentava terreiros de umbanda com sua tia materna. Na infância, teve uma formação católica completa devido à intenção materna de apresentar-lhe ao menos um caminho religioso. Mas a atração pelo batuque foi maior que tudo.

Em 1990, tia Alzira inaugurou um pequeno terreiro de umbanda no quintal da família, que por motivos de doença da mesma, passara a ser comandado por ele, a princípio temporariamente, e depois definitivamente. É no advento da inauguração deste terreiro, que pai Carlito vivencia sua primeira experiência de transe, pois até então sua participação na religião era como cambono $o^{50}$ e $\operatorname{co} \tilde{a}^{51}$. Com a doença de tia Alzira, suas entidades haviam lhe pedido para dar continuidade aos "trabalhos" da casa, que nesse momento já possuía uns trinta

\footnotetext{
${ }^{50}$ Cambono ou cambone: termo utilizado na umbanda para designar aquelas pessoas que auxiliam as entidades manifestadas durante os rituais.

${ }^{51}$ Ogã : na umbanda, cargo masculino do tocador de atabaques, executado por um médium que entra em transe ou não. Há casos também em que encontramos mulheres realizando a tarefa. Dentro do candomblé, esse cargo tem outras especificações que serão explicitadas posteriormente nesse trabalho.
} 
médiuns.

Como uma forma de ter suporte de conhecimento e legitimidade de sua função sacerdotal, Calos ingressou paralelamente no corpo mediúnico de outro terreiro na vizinhança, para realizar as devidas cerimônias de iniciação formal na umbanda. Após um período de quatorze anos, pai Carlito decide passar pela iniciação no candomblé, acreditando que encontraria mais conhecimento para dar continuidade ao que julgava ser sua missão espiritual. Logo na primeira entrevista, ele narrou suas primeiras visitas aos candomblés com amigos e seu paulatino encantamento com a beleza da religião.

Com a sua feitura, seu terreiro passou por uma intensa transformação. Muitos médiuns saíram da casa de santo por não aceitarem os novos procedimentos rituais. Então, aos trinta e dois anos, a iniciação de pai Carlos e de vários de seus familiares deu rumo a uma nova etapa de sua "carreira" sacerdotal. Determinado a constituir uma grande família espiritual, o pai-de-santo trabalhou com afinco para o aprimoramento de seus conhecimentos e da estrutura material de seu templo. Recorrentes festas beneficentes e rifas estavam sempre em andamento em prol das inúmeras obras de expansão e adequação a nova forma de culto aos orixás.

Embora muitas pessoas tivessem achado que a prática da umbanda acabaria, não foi o que aconteceu. Pai Carlito mantém há anos a prática paralela das giras de umbanda em dias separados do candomblé, o que gera um extenuante calendário que os filhos-de-santo tentam cumprir com exigente compromisso. Em muitos episódios, inclusive após a feitura de seus próprios filhos-de-santo, ele fazia questão de afirmar a mesma importância de ambas as crenças, a umbanda e o candomblé. Ele parecia não concordar com as pessoas que após serem feitas largavam o culto das entidades de umbanda. Sempre que podia, demonstrava sua profunda gratidão por estas entidades, afinal foi pelas portas de entrada da umbanda que ele chegara a ser um babalorixá ${ }^{52}$.

O candomblé de pai Carlito está situado numa região bastante urbanizada e de fácil acesso para clientes e filhos-de-santo. Ao longo de minha vivência no terreiro, presenciei o trabalho incansável de arrecadação de fundos para a compra de um terreno maior visando à construção de um barracão mais amplo, que

${ }^{52}$ Babalorixá: correlato em iorubá da expressão pai-de-santo. Para as mulheres usa-se mãe-desanto ou ialorixá. 
acomodasse seus mais de cem componentes.

A rotina do sacerdote era bastante intensa, já que não trabalhava formalmente. Os conhecimentos adquiridos na graduação em Administração pareciam ser aplicados na maneira como conduzia seu terreiro, ou seja, com a chamada visão empresarial. Como havia me declarado certa vez, as funções sacerdotais foram lhe exigindo cada vez mais de seu tempo, posto que ele tinha mais de uma centena de filhos-de-santo.

Para sustentar a família civil, além do salário da esposa, contava com os proventos advindos dos diários jogos de búzios e serviços rituais demandados por uma vasta cartela de clientes e de seus numerosos filhos-de-santo. As sessões e festas de umbanda serviam como um poderoso atrativo para os visitantes, que na maior parte das vezes retornavam para um jogo de búzios e quiçá, se tornavam filhos espirituais de pai Carlito. Sem dúvida, os comentários eram unânimes sobre sua simpatia cativante e uma humildade diferencial entre os pais-de-santo, como uma frequentadora e alguns abiãs me confessaram. Quando chegava às festas, ele fazia questão de cumprimentar a todos na assistência, e ao término de cada jogo de búzios, conduzia gentilmente o cliente até a porta de saída do barracão. Detalhes que fazem total diferença na circulação de adeptos pelo universo diversificado e competitivo do candomblé. Conforme me explicou certa vez, ele sabia que as pessoas vinham sempre em busca de uma atenção individualizada.

Nos últimos quatro anos diversos abiãs circularam em seu terreiro. Cada um deles compartilhando comigo suas histórias vividas neste e em outras comunidades litúrgicas. Vários deles eu não consegui entrevistar formalmente. Em diversas situações, após um tempo sem aparecer no campo, recebia a notícia de que alguns haviam se afastado. Contudo, falar sobre as pessoas que saíram do axé - fossem elas feitas ou não - era sempre um interdito a ser vigiado pelos mais antigos. Uma das lições que aprendemos sobre o candomblé é que a quantidade de filhos-de-santo e clientes é um sinal inquestionável de prestígio, por conseguinte, a subtração de membros gera a impressão oposta: o desprestígio no meio religioso. Embora essas saídas nunca fossem assuntos valorizados, em certas oportunidades, pai Carlito desabafava sua angustia em ter que lidar com os valores, segundo ele, "involuídos" deste mundo capitalista, que dificulta cada vez mais a entrega do abiã à religião: 
O mundo na minha opinião não tá evoluindo. Ele tá involuindo. Porque a evolução tecnológica do mundo, ela tá retardando a evolução do homem. O homem tá se tornando mais preso aos bens materiais.[...] Hoje as facilidades que nós temos hoje faz com que o abiã de hoje está menos respeitoso, apegado, menos preso a questão religiosa. [...] Não querem perdê seu tempo, ou dedicá seu tempo à religião... né [...] As pessoas querem chegá lá, tomá um banho de folha, acendê sua vela, fazer sua obrigação e ir embora. [...] Porque tem que trabalhá, trabalhá, trabalhá... ganhá dinheiro, ganhá dinheiro, ganhá dinheiro... porque as pessoas consomem muito e tem que pagá, pagá, pagá! [...] querem ir lá, fazê o seu e ir embora. [...] As pessoas tão numa correria absurda na vida [...] não tem ou não querem tê tempo simplesmente de pará, ir pra uma roça de candomblé, tomá seu banho de folha, dedicá um, dois, três dias ali. Esquecê da vida! E ficá ali junto ao santo. Porque acha que é perdê tempo! (pai Carlito)

A convivência neste e noutros terreiros deixa evidente que, de fato, boa parte das pessoas apresenta uma relação de consumo imediatista com os rituais propostos. Entretanto, no que tange ao barracão de pai Carlos, havia um murmúrio constante a respeito de uma hipertrofia de atividades, tanto pela dupla jornada entre umbanda e candomblé, quanto pelas constantes feituras.

Desta forma, muitas das vezes eram os abiãs - na sua avidez por pertencimento - que mais assiduamente compareciam às convocações. No bojo dessas atividades, para além da ritualística propriamente dita, havia mutirão de faxina, de pintura, de ornamentação das festas etc. De modo geral, o tema do engajamento nas atividades da casa sempre era um estopim para conflitos, que aborreciam demais ao sacerdote. Porém, as cobranças eram realizadas indiretamente de forma a não precipitar o afastamento de algum membro do templo. A bem da verdade, pai Carlito era um típico sacerdote em início de "carreira" no candomblé, para o qual todo abiã era sempre bem-vindo. 


\title{
"O encanto começa quando vê a festa": "espetáculo" e performance nos candomblés
}

\begin{abstract}
[...] the basic stuff of social life is performance, "the presentation of self in everyday life" (as Goffman entitled one of his books). Self is presented through the performance of roles, through performance that breaks roles, and through declaring to a given public that one has undergone a transformation of state and status, been saved or damned, elevated or released. (Turner, 1987, p. 81)
\end{abstract}

Fim de tarde num sábado de Setembro de 2014. Duas semanas de trabalho árduo dos religiosos estavam sendo coroadas com mais uma noite de alegria e festa, dentre tantas outras na roça de santo. Era a etapa conclusiva de um longo período de difícil conciliação entre a vida profissional, familiar e religiosa.

Eu e meu companheiro estacionamos o carro na subida. Numa rua estreita e inclinada, onde o terreiro de pai Carlito se localizava, naquela noite havia uma fila de carros e um movimento constante de filhos-de-santo com suas malas de viagem e suas roupas rituais em cabides multicoloridos, dos quais pendiam inúmeras sacolas. Uns poucos desciam das combes sobrecarregados de bolsas, enquanto algumas caronas denunciavam a solidariedade típica.

O movimento de chegada e entrada, tanto de religiosos como de visitantes, trazia à tona de minha memória a atmosfera das horas que precedem um espetáculo no teatro. Havia um fluxo diverso de pessoas que mesclava o clima de bastidores com o de uma plateia alvoroçada pelo início de uma peça teatral. Imediatamente, relembro aquela olhadela que o ator dá entre cortinas para apreciar a chegada do público. Mas nesta ocasião, eu era o público! De repente, alguém acendeu a iluminação externa do terreiro. Tudo se iluminou ainda mais como numa faixada de teatro.

Tangenciando a movimentação na porta do terreiro, vê-se a passagem esporádica de moradores do entorno com olhares curiosos. No portão vizinho à casa de axé, um possível sinal de intolerância: alto-falantes posicionados para fora em volume máximo disseminavam o funk que possivelmente abafaria o incômodo toque dos atabaques em eminência, ou mesmo, causaria ruídos propositais na orquestra sacra que se precipitava ao cair da noite. 
Lá de cima do templo, alguns filhos-de-santo com celular na mão, num aceno de reconhecimento, sinalizavam para seus convidados o local de chegada. Às vezes, alguns desciam para recepcionar os amigos e parentes. Eu via do meu carro, que algumas mulheres que estavam de calça amarravam panos na cintura ou vestiam uma saia pela cabeça antes de entrar no recinto religioso. O branco era a cor preponderante naquele fluxo todo. Aquela não era uma porta qualquer e sua simples transposição era ritualizada pelos mais íntimos do candomblé.

No asfalto imperfeito da ladeira podiam ser vistos ainda os resquícios de cerimoniais realizados ao longo do dia. Restos de padêt $\hat{e}^{33}$ misturados num amálgama - desconhecido para muitos vizinhos e visitantes - de grãos, farelos, ervas, água e um líquido branco leitoso. Do portão de entrada entreaberto, um misto do cheiro de estrume e sangue animal fresco era exalado. Na superfície do portão de alumínio branco encardido, recoberta pela penugem de algum frango sacrificado, como que uma pincelada de sangue parecia selar a entrada do espaço sagrado.

Os religiosos na sua etiqueta cerimonial de chagada abriam o portão e aspergiam água limpa para rua, que era retirada fartamente de um vaso grande de barro ali posicionado. Num lance, ouvi alguém comentar o possível perigo daquilo para a disseminação da dengue. Como conhecia o código ritual, repeti o gesto para entrar. Em seguida, senti novamente o cheiro de estrume exalado ao precipitar

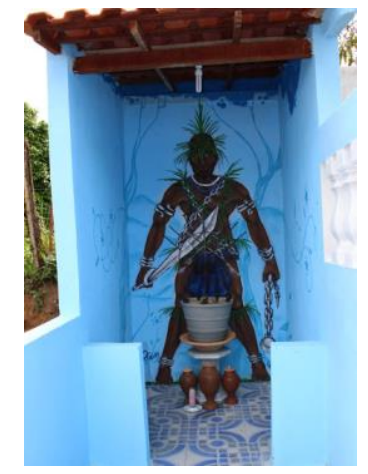

Figura 1: Assento de Ogum Fonte: Google Imagens ${ }^{\circledR}$ da porta. Saudei os assentamentos de Exu e Ogum,${ }^{54}$ que reconheci sob a mistura de azeite de dendê e sangue, decorados com penas de frango e galo. Vi que o vento apagara uma vela, que estava caída sobre uma generosa camada de padê. O cheiro de velas acesas era inconfundível.

\footnotetext{
${ }^{53}$ Padê: comida ritual preparada com farinha de mandioca misturada ao azeite de dendê. Mas pode ser feita também com água ou cachaça. Alimento votivo endereçado à divindade Exu (o mesmo que eká de Exu). Padê, em iorubá, significa encontro, reunião. Pelo seu oferecimento dá-se o encontro do homem com o orixá. Ver: Lody (2003); Cacciatore (1977).

${ }^{54}$ Assentamento de Exu e Ogum: os assentamentos, corruptela de assentos, são representações materiais das divindades. Operam como se estas estivessem "sentadas" no altar de culto (peji). Exu e Ogum são divindades com laços de irmandade na mitologia do candomblé. Exu é a divindade dinamizadora do universo, patrono da comunicação e das encruzilhadas. Seu irmão Ogum, no Brasil está relacionado à forja dos metais e aos caminhos. Ambos estão na categoria de orixás olodês, ou seja, do lado de fora. Ver: Beniste (2015); Cacciatore (1977); Lody (2003).
} 
Subo a longa rampa de acesso ao barracão. No caminho, na primeira curva, alguns filhos-de-santo fumam o último cigarro longe das dependências internas e do olhar vigilante de pai Carlito. Passam por mim uma senhora e um

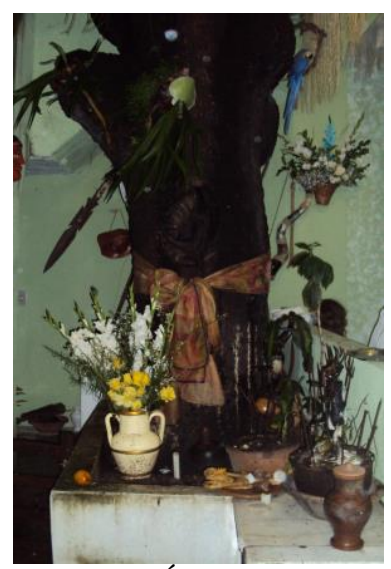

Figura 2: Árvore sagrada e assento de Exu à direita Fonte: Acervo da pesquisa abiã carregando um cheiroso bolo todo confeitado de branco. O cheiro e a transparência das sacolas de mercado denunciavam os docinhos de festa. Há indícios diversos de que uma demorada obra de reforma ou construção se faz no lugar: pilhas de cerâmica, sacos de areia, toras de madeira, novas louças de banheiro encardidas de poeira. Alguns espaços da arquitetura bem acabados e outros em tijolo e cimento grosseiro, que faziam fundo para lindos tecidos floridos que enfeitavam com laços amplos as pilastras e árvores do quintal.

Conforme subo, o burburinho aumenta. Falas, chamados, risos, toques de telefone, o cacarejar típico de algumas galinhas d'angola, o ruído de louça sendo lavada, a afinação dos atabaques, panelas caindo no chão, uma algazarra infantil. No telhado, alguns homens posicionam caixas de fogos de artifício. De pés no chão e roupa branca e um único colar ritual branco, um abiã passa com sacos de lixo pingando um líquido viscoso. Em seguida, ele e outro ajudante repõem os copos descartáveis do filtro d'água.

$\mathrm{O}$ vento do quintal parece espalhar no ar o cheiro das cabeças, asas e patas de galinha penduradas nas árvores sagradas por uma trança de palha da costa ${ }^{55}$. Nas paredes recobertas de cal, moscas insistentes rondam o couro estirado dos bichos recém-imolados aos orixás. Quando o vento chega mais forte, o cheiro de carniça se intensifica e se perde no aroma apetitoso dos acarajés que as mulheres coquetes fritam na cozinha barulhenta. O cheiro de cebola, camarão e dendê impõem-se quando chego ao espaço que antecede o salão onde iria acontecer a festa.

Alguns olhares me reconhecem com afeição e outros me investigam.

\footnotetext{
55 Palha da costa: trata-se de uma fibra de ráfia extraída de uma palmeira africana (Igí-Ògòrò). Muito utilizada em diversos procedimentos rituais (vestes, ritos iniciáticos e cerimoniais). Sua simbologia é a da eternidade e transcendência. Em sua falta, pode ser substituída pela folha do dendezeiro seca e desfiada, conforme indica Lody (1992).
} 
Dezenas de mesas e cadeiras plásticas, espalhadas no quintal entre a cozinha e o salão principal, anunciam a chegada de muitos convidados para a noite. À espera deles, a delicadeza de um vasinho artesanal como lembrança da festividade decora o centro das mesas, ali dispostas como num salão de festas.

Pela fresta de uma porta improvisada que separava este espaço das dependências internas nos fundos, minha atenção é capturada quando vejo um jovem fazer a barba rapidamente com um pequeno espelho de mão e uma bacia de ágate cheia d'água. Disfarço e me aproximo mais da abertura, mesmo temendo ser descoberto em minha indiscrição antropológica. Ao redor do rapaz, saias e anáguas se esbarravam no espaço restrito em que mulheres se maquiavam, perfumavam e colocavam lindos turbantes, ricos colares rituais e reluzentes pulseiras. A sonoridade aguda das pulseiras e braceletes - usados por homens e mulheres - se mescla com as palmas ritmadas e o tilintar do guizo atado ao pé de um iâ que passa agachado e coberto por um lençol branco para ir ao banheiro.

Alguns devotos ainda se caracterizavam cuidadosamente para a ocasião conferindo os emblemas hierárquicos, enquanto outros, já prontos, esperavam com semblantes ambíguos de cansaço, excitação e expectativa. Percebo que o banheiro é disputado numa dinâmica de gentileza e hierarquia. Aquela fresta entre a tábua e o muro mal acabado abria para minha observação um universo bastante conhecido, devido minha pertença religiosa. Não há como afugentar da memória a aura típica dos camarins de teatro que por um longo tempo também frequentei. Aquela era a visão parcial dos bastidores da festa, sempre possível de serem vistos nos atrasos recorrentes dos candomblés que visitei e vivenciei.

Subitamente, minha divagação é interrompida pela chagada de pai Carlito, que com toda sua receptividade de excelente anfitrião, logo me oferece um café. Agradeci, mas preferi aguardar a troca do galão de água. Num grito, alguém avisou que o pai-de-santo iria começar a roda. O calor era intenso. Ele estava aflito com a hora. Muita gente circulava pelo espaço. Muito contente, o sacerdote agradeceu minha presença levando-me ao interior do salão principal, o barracão propriamente dito. Este, numa amplitude de aproximadamente $120 \mathrm{~m}^{2}$, estava todo iluminado e repleto de flores. O espaço era circundado por dezenas de cadeiras plásticas para a audiência esperada, que se diferenciavam daquelas ornadas com tecidos e laços, numa região privilegiada próxima à orquestra ritual, que seriam ocupadas por convidados ilustres. 
No amplo salão, há dois pontos em que a própria estética sublinha uma maior relevância no gradiente do sagrado. No meio, azulejos diferentes destacavam o centro de força da casa, propriamente o $\operatorname{ariaxé}^{56}$, que nesta ocasião estava ornamentado por um suntuoso arranjo floral. Mais a frente, ao lado da cadeira de pai Carlito, uma espécie de palco de alvenaria dispunha em destaque o terno de atabaques ${ }^{57}$, acompanhados de um agogô e um colorido xequerê. Num pequeno vaso de barro cru, inúmeras varetas.

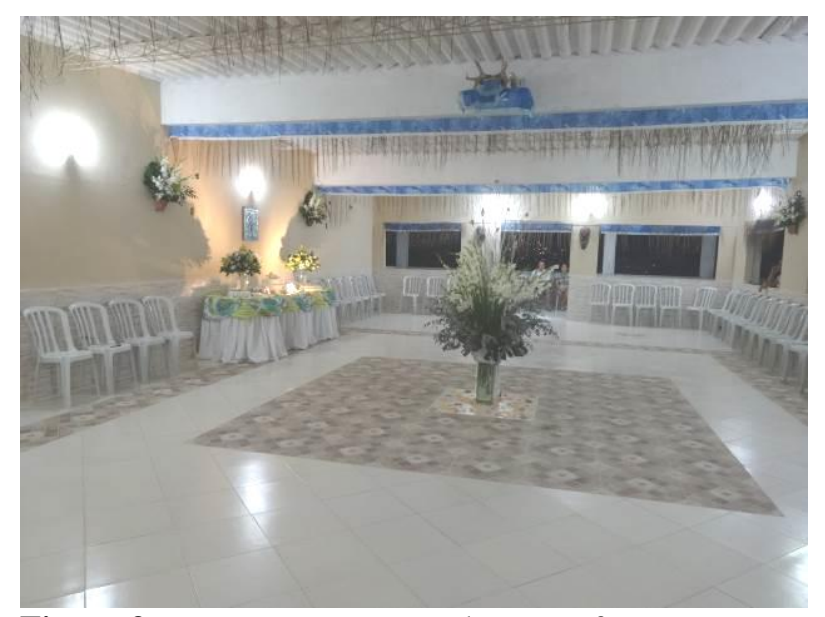

Figura 3: Barracão ornamentado para a festa Fonte: Acervo da pesquisa

O sacerdote cumprimentava a todos com muita simpatia e recebia aos seus pés o cumprimento ritual de alguns iniciados. Parecia orgulhoso de finalmente estar me mostrando um momento diferente daqueles que presenciei nas visitas e entrevistas anteriores. Era como se ali algo se completasse na narrativa sobre sua trajetória na religião. Como se eu estivesse tendo acesso ao que nenhum discurso poderia me explicar. De acordo com o que ele sempre me dizia: "o candomblé babazinho $^{58}$, só vivendo!” A beleza da ornamentação da festa - que não deixava a desejar para as casas de festas profissionais - era capturada incessantemente pelas

\footnotetext{
${ }^{56}$ Ariaxé: corruptela do termo ixé: cavidade central no chão de um terreiro onde são enterrados os assentos e sacrifícios rituais, que formam o centro irradiador da força dinâmica realizadora (axé) que sustenta a comunidade litúrgica. Em alguns templos, é erguido sobre ele um poste central no qual outro assento superior é depositado para representar a divindade patrona daquele terreiro. Esta estrutura também representa a ligação entre a terra (aiê) e a esfera imaterial (orun), unindo simbolicamente os ancestrais, os vivos e os orixás. Ver: Cacciatore (1977); Lody (2003).

57 Terno de atabaques: rum, rumpi e lé (ou runlé), respectivamente grande, médio e pequeno. Estão sempre presentes no candomblé. São sacralizados e utilizados para as evocações rituais de todos os tipos. Eles passam por uma iniciação ritual cíclica e recebem as vestes e reverências apropriadas, pois são também divindades. Para maiores informações ver: Barros (2005); Sabino \& Lody (2011).

${ }^{58}$ Babázinho: saudação afetuosa que significa "paizinho" ou "papai" na "língua do santo".
} 
câmeras digitais e os celulares dos religiosos e alguns de seus convidados.

O abafamento aumentava. Eu sentia muita sede e certo desconforto pelo atraso, que anunciava o prolongamento da noite de observação participante. $\mathrm{O}$ aroma do arroz refogado e do dendê saturado que vinha da cozinha mistura-se aos diferentes perfumes dos convidados, das flores e do cheiro do banho de ervas exalado pela passagem apressada dos filhos-de-santo.

Os atabaques começaram a rufar e uma enorme fila indiana adentrou o salão, numa profusão de sons, estamparias e corpos em movimento circular antihorário ao redor do arranjo floral central. Alguns espectadores colocavam para fora da blusa seus colares rituais e se levantavam com a mão direita espalmada em sinal de respeito e reverência ao cortejo de membros do terreiro. A sequência musical era rica em ritmos, letras e danças. A gestualidade era solene e rígida. Nos primeiros indivíduos, uma segurança maior no movimento do corpo e dos pés. Ao final da fila, abiãs com seus corpos vacilantes com olhares inseguros e expectantes.

Uma emoção inicial me fez pensar no receio de entrar em transe de orixá aquela noite, afinal não estava lá com esta intenção. Porém, me desfaço desta angústia ao pensar que um olhar não treinado poderia permanecer perdido em meio a tanta informação sensorial e, portanto, necessitar de muitas outras visitas para identificar e organizar os múltiplos elementos que compunham aquela cena de intensos estímulos. Entretanto, cônscio de meu objetivo naquela noite e familiarizado com todos aqueles códigos, passei a selecionar as imagens concernentes ao meu exercício antropológico em questão. Arrisco afirmar que qualquer "leigo" em contato com uma noite como essa no terreiro de pai Carlito, seria capturado de imediato pela beleza ostensiva dos primeiros indivíduos da fila, quiçá da maioria dos participantes que dançavam. Melhor dizendo, estando ordenados por idade iniciática, são os primeiros da fila cerimonial que possuem as vestes mais elaboradas e requintadas. Assim como, uma evolução de maior protagonismo no salão. Neste requinte, incluo os tecidos mais caros, as estampas mais atraentes, o uso de sapatos de salto alto para as mulheres e sandálias de couro para os homens, suntuosos torços nas cabeças, as pedrarias mais valiosas e a postura sempre ereta. Os abiãs no final fila por vezes se prostravam de joelhos e faces voltadas ao chão.

A música e a dança ritual cresciam num frenesi bastante envolvente. A 
intensa sonoridade costurava o toque dos atabaques com os gritos de louvor, o agogô estridente, as palmas, o zumbido do xequerê, o cântico passional dos adeptos, os adjás ${ }^{59}$ insistentes, e os marcantes ilás ${ }^{60}$ dos orixás que se manifestavam num ápice de efusão coletiva. $\mathrm{O}$ transe simultâneo de muitos filhosde-santo modificava o cenário e os atores. $\mathrm{Na}$ assistência, algumas pessoas também entravam em transe e eram imediatamente acolhidas por um filho-desanto com uma tira de pano bem engomada. Expressões faciais contorcidas, sob o suor intenso e a amplificação do gestual, demarcavam a experiência mais esperada pelos participantes da performance do candomblé naquela noite festiva.

De repente, os atabaques pararam. Cessou bruscamente todo o estímulo sonoro. Um hiato de silêncio, misto de solenidade e estupefação, foi produzido por todos os presentes simultaneamente, como se tivesse sido ensaiado. Segundos de introspecção que pareceram eternos em contraste com a farta sonoridade anterior.

Agachados no chão com olhos expectantes ou recuperando-se de fortes sensações, na simplicidade de suas vestes e atuações, alguns abiãs dirigiram-se à cozinha em busca de copos d'água trazidos em bandejas de prata e panos de chão para enxugar pequenas poças de suor do salão. Livre das vistas alheias, os orixás dos iniciados estavam sendo paramentados com suas vestes e insígnias de gala para a posterior saída da corte. Voltaram os comentários e cumprimentos atrasados ao pai-de-santo, cresceu a fila do banheiro e foi servido refrigerante e salgadinho. O cerimonial inicial estava apenas introduzindo a longa noite de ritual e festa, de entretenimento e experiência sagrada para os religiosos do terreiro e seu público visitante.

Esta foi uma experiência como muitas outras que se repetiram no meu percurso etnográfico nos últimos quatro anos. A relevância da dimensão "espetacular" e performática do candomblé (Amaral, 2002; Santos, 2005; Souza, 2007) foi se tornando cada vez mais perceptível, ao passo que eu avançava nas visitas aos terreiros e no conhecimento das biografias de meus interlocutores. $\mathrm{O}$

\footnotetext{
59 Adjá: corruptela de adjarim. Sineta ritual composta de uma ou várias campânulas de metal presas a um cabo. Utilizada nas cerimônias litúrgicas para evocar e/ou manter a presença dos orixás. Mais informações ver: Barros (2005).

60 Ilá: espécie de grito ou brado que o adepto-orixá produz em transe de orixá. Trata-se da manifestação de sonoridade produzida pelo corpo do iniciado e constitui uma das marcas identitárias de sua divindade pessoal. Para maiores informações ver: Cacciatore (1977).
} 
transcurso dessa pesquisa tornou-se a constatação do caráter inclusivo que Richard Schechner (2003, 2011, 2012 a, b) atribuiu à noção de performance, entendendo que o "teatro é somente um ponto num continuum que vai desde as ritualizações dos animais (incluindo humanos) às performances na vida cotidiana [...] e às apresentações espetaculares" (Schechner, 2012a, p. 18) .

\title{
3.1
}

\section{“É lindo! É bonito! É fantasia! É aquela coisa bonita de se ver!” - Candomblé para crer, ver e ter prazer}

\begin{abstract}
"Desaparece a persona dos filhos-de-santo que, vestidos como reis e rainhas, desenvolvem sua performance. Não obstante isso, a individualidade permanece. A consciência pessoal não é eliminada pelo transe, e sim levada a conviver com a função sagrada de atuar em um espetáculo divino. Neste teatro, em vez de o ator empunhar uma máscara, ele se despe do seu papel social para revelar o que há de mais sagrado dentro de si." (Ligiéro, 2006, p. 133, grifos do autor)
\end{abstract}

“Cantar-dançar-batucar" é o dispositivo que sustenta variadas manifestações culturais africanas e afro-brasileiras, segundo Zeca Ligiéro (2011) em seu prolongado estudo sobre as performances culturais no Brasil. Ao analisar variadas formas de performance afro-brasileiras como a capoeira, o samba, o candomblé e a umbanda, o autor procura compreendê-las em sua dimensão estética, a partir de diversas conexões com as culturas africanas envolvidas na diáspora forçada ao longo de séculos.

Nestas práticas culturais, o corpo apresenta-se como elemento chave no funcionamento do que Ligiéro (2011) nomeou de "motrizes culturais", ou seja, uma variante do insuficiente termo matriz, que para ele não expressa "a complexidade dos processos interétnicos e transitórios verificados nas práticas performativas ou performances culturais" (Ligiéro, 2011, p. 107). Segundo o mesmo autor, o termo matriz (do latim matrice: lugar que gera) engendra uma ideia de fixidez, como a de um molde que se reproduz igualmente em diferentes circunstâncias. No entanto, o que se verificou no processo de reelaboração das culturas africanas no Brasil, diz respeito a uma confluência de diversas origens que se reconfiguraram num processo dinâmico e dialético constante. No âmago dessas motrizes (do latim motrice de motore: que faz mover), está posicionado o corpo do performer, que é o seu texto, pois "nele se corporifica uma literatura 
viva, desenvolvida a cada apresentação, refletindo o conhecimento que tem da tradição" (Idem, 2011, p. 111).

Desta maneira, a dança expressa pela conjunção do corpo com a música e o canto, caracteriza um ambiente "celebratório-ritualístico com grande capacidade de interatividade e participação do público presente, quase sempre gente do mesmo grupo ou de convidados e simpatizantes" (Idem, 2011, p. 131).

Portanto, percebendo as semelhanças entre diversas danças africanas e as performances do corpo nas manifestações de matrizes africanas em nosso país, o autor concorda quando Fu-Kiau (Ligiéro, 2011, p. 134-135) salienta a impossibilidade de analisar as danças africanas isoladamente, já que elas constituem apenas uma parte da performance, que na sua completude, une religião e entretenimento, constituindo um objeto composto, amarrado. Haveria para este estudioso das danças subsaarianas, o que ele aponta como um continuum entre "batucar-cantar-dançar", no qual, através das performances, articula-se uma espécie de linguagem espiritual. Da mesma forma como nas danças dos povos Chokwe analisadas por Fu-Kiau (Ligiéro, 2011, p. 134-135) - em rituais que ocorrem em arenas, procissões ou ambas as formas - os devotos tocam tambores, dançam e cantam, propiciando uma integração entre divindades, ancestres e humanos.

$\mathrm{Na}$ sua argumentação, Ligiéro (2011) procura destacar este caráter integrador da performance, na mesma acepção proposta por Schechner (2003; 2012a), ao salientar que "não são poucas as pessoas que frequentam missas tanto pelo prazer estético e pela socialização quanto pela fé. [...] Em muitas culturas, a performance participativa é o âmago da liturgia" (Schechner, 2003, p. 31). Defendendo este ponto de vista, Schechner (2013) segue exemplificando com os festivais teatrais da Grécia antiga, nos quais se reunia ritual, arte, competição e entretenimento popular.

Por conseguinte, podemos identificar no contexto dos candomblés a mesma ocorrência, devido tais características intrínsecas, principalmente a do aspecto festivo da faceta pública de seu cerimonial litúrgico. O denominador comum "cantar-dançar-batucar", que perpassa toda a prática religiosa de matrizes africanas (Ligiéro, 2011), configura-se também como um instrumento de religação (religare) da experiência social e religiosa dos fiéis, no momento único da performance nas festas dos terreiros. Isto desconstrói de vez a clássica separação 
entre religião e entretenimento, pela revelação da relação de complementaridade, notada na forma estética e na atuação dos performers, na dança dos e para os orixás. O modelo analítico proposto por Schechner (1988; 2012a, b), que é claramente incorporado por Ligiéro (2011), rompe definitivamente com a concepção de Durkheim (1996) sustentada por uma oposição binária e dicotômica, que apresenta uma dimensão "sagrada" em oposição à outra "profana", na constituição dos eventos performáticos da vida social.

Revisitando criticamente a fundante teoria sobre as fases invariantes dos rituais, elaborada por Van Gennep (2011), e numa interlocução profícua com a abordagem de Victor Turner $(2005 ; 2013)$ sobre dramas sociais e o caráter processual dos rituais, Schechner (1988) no seu olhar de diretor teatral, propõe a inovadora relação entre teatro e rito. Investigando performances teatrais em diversas partes do mundo, sua análise comparativa torna-se bastante contundente.

Com isso, sua nova forma de pensar o conceito de ritual - tão relevante nas discussões antropológicas - irá insistir nesse fluxo continuum entre ritual e teatro, e vice-versa. Na sua definição de performance, não há diferenciação da natureza de ambos os eventos. O prisma de sua análise é o teatro, ressaltando sempre a relação de interação entre os performers e a audiência.

A interlocução entre as ideias de Turner e Schechner consolidou-se, de fato, numa valiosa parceria intelectual que gerou inúmeras publicações e organização de diversos eventos conjuntos, que marcaram a fundação dos chamados Estudos da Performance. (cf. Carlson, 2011; Silva, 2005a; 2012). Além do que, a análise do ritual com foco no teatro irá influenciar sobremaneira a própria produção acadêmica final de Victor Turner. Como ressalta Langdon (1996, p. 25), foi exatamente no final de sua carreira que ele redirecionou seu aguçado interesse pelos ritos e dramas sociais de sociedades tribais, para o estudo do que identificou com performance cultural. Nesta ocasião, a influência de Erving Goffman com sua abordagem dramatúrgica da realidade social e de Schechner com a percepção do continuum entre teatro e ritual saltam aos olhos. Mesmo assim, Turner fez questão de pontuar as especificidades das análises de cada um deles: "I mean the performance of a complex sequence of symbolic acts [...] What is more interesting to me in this context than the definition of ritual is the connection established by Schechner between social drama and theatre" (Turner, 1987, p. 750). 
No prefácio de seu primeiro livro "Performance Theory" (1988), Schechner apresenta um quadro ilustrativo bastante aclarador sobre seu pensamento a respeito das imbricações das múltiplas formas de performance e seu amplo espectro, utilizando-se das metáforas do "leque" e da "rede", que parece conveniente resgatar:

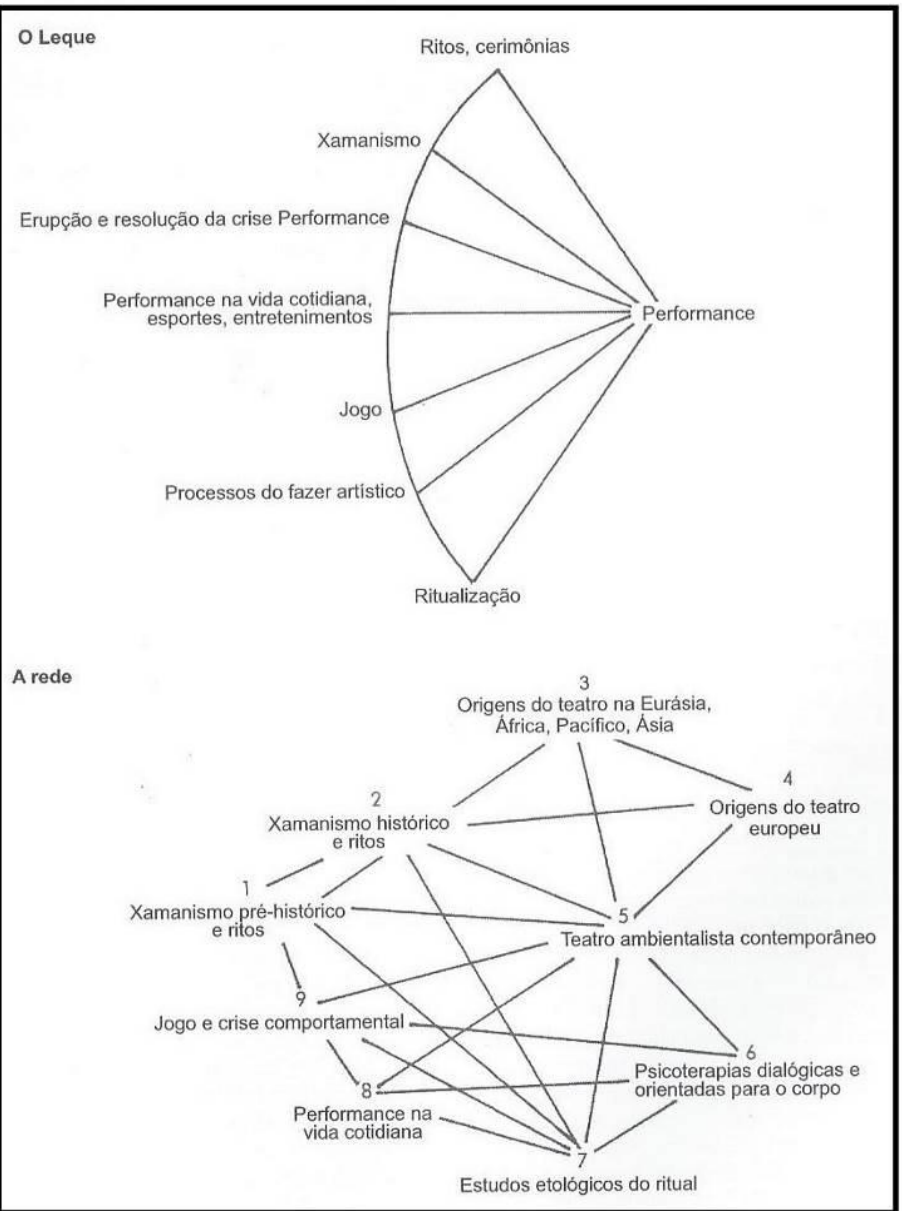

Figura 4: Diagrama Leque e Rede - Richard Schechner Fonte: Schechner (2012a, p. 17)

Em 1966, num de seus escritos fulcrais na revista "Tulane Drama Review”, Schechner afirma: “a performance é uma categoria abrangente que inclui brincadeiras, jogos, esportes, o desempenho na vida cotidiana e ritual como parte de um fluído da atividade teatral" (Schechner, 2012a, p. 13). Sua proposta de compreensão mais "ampliada" do conceito de performance fica bem clara em seus esquemas ilustrativos, a partir das metáforas do "leque" e da "rede".

Na proposição da "rede", um mesmo sistema é operado, porém de maneira menos uniforme e mais dinâmica, onde os pontos interagem entre si, ao invés de estarem espalhados ao longo de um continuum. Como pode ser percebido e explicado pelo autor, o teatro ocupa no esquema uma posição arbitrária, pois é o 
ângulo central de toda sua análise.

É justamente este caráter integrador desses eventos públicos percebidos como performance, que justifica a escolha da teorização de Schechner (1988; 2003; 2012a, b) para apreender a dimensão “espetacular" e performática do cerimonial público dos candomblés. É no bojo desses eventos performáticos que os abiãs encontram-se em contínuo aprendizado e treinamento. Afinal, como também enfatiza Schechner (1988; 2003; 2011, 2012 a, b), o esquema profundo da performance conta com uma elaborada preparação prévia, que constitui uma etapa da qual performers e espectadores sempre participam. Os performers passam por ensaios, treinamentos, workshops etc. Enquanto que os espectadores da performance vivenciam previamente momentos de preparação, percebidos no ato da decisão de ir assistir, do vestir-se adequadamente para o evento, no trajeto de ida ao local, acomodando-se na chegada e esperando o início.

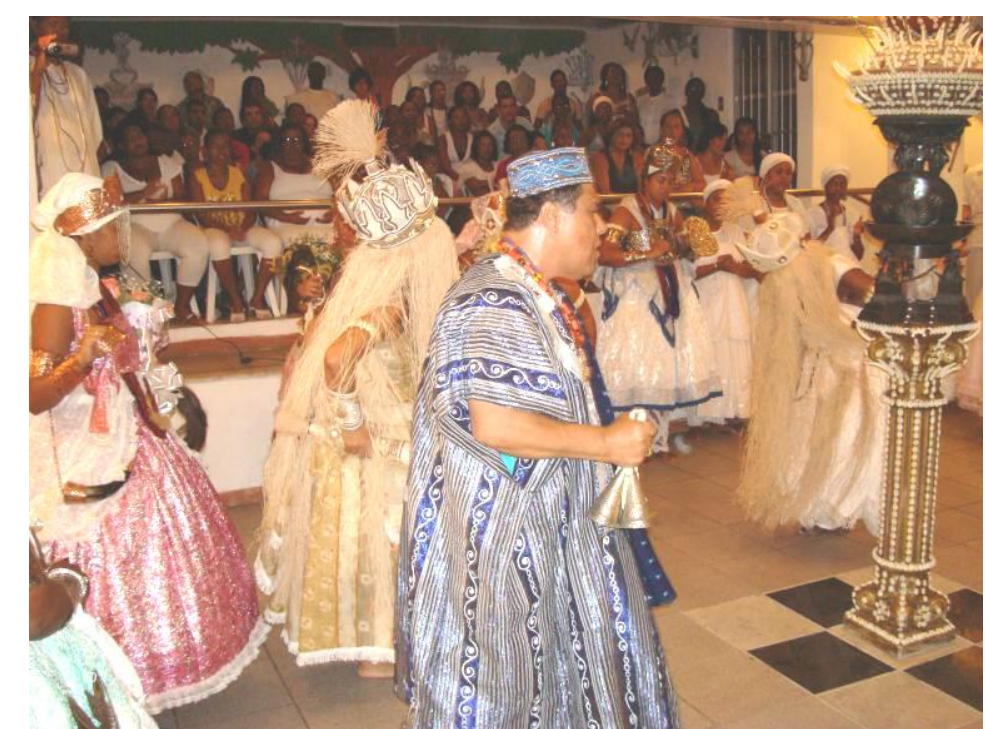

Figura 5: O xirê - cenário, plateia e performers Fonte: Google Imagens ${ }^{\circledR}$

Por tudo isso, na dinâmica cotidiana de um terreiro de candomblé, o esquema detalhado dos elementos e fases da elaboração de uma performance proposto por Schechner $(1988 ; 2003 ; 2012 a, b)$ pode ser facilmente eleito como perspectiva de interpretação da dimensão teatral que constitui o ethos do povo-desanto (cf. Amaral, 1998; 2002). Principalmente, quando percebe-se o abianato como uma das etapas preliminares que capacitam um indivíduo para atuar no efetivo "espetáculo" que é a festa dos orixás, na qual iniciados, postulantes à iniciação e espectadores, contracenam e comungam da mesma experiência 
performática. Cantando, dançando e batucando, é possível deleitar-se esteticamente, exercitar a fé e divertir-se em grupo, sem nenhuma espécie de contradição no louvor às divindades afro-brasileiras.

\section{2}

\section{"Parece um carnaval assim meio fechado" - Descortinando o "espetáculo" dos orixás}

[...] você tá vendo? Aqui você vê o teatro. Mas antes do teatro e depois do teatro, além de ser, vamos dizer... os atores, nós também somos os figurantes que fazem tudo! (abia Afonsinho)

O teatro como metáfora do candomblé foi inúmeras vezes acionado pelo discurso de meus interlocutores no período que estive no campo. Obviamente, em minha longa vivência como adepto das religiões de matrizes africanas, em diversas circunstâncias também realizei esta associação. Além do que, minha formação profissional como ator e toda a trajetória que vivi em diferentes companhias teatrais, me inclinam facilmente a perceber os aspectos que constituem a dimensão "espetacular" da ritualística do candomblé.

Seu rebuscado aparato estético (vestes rituais, insígnias, joalheria, estamparia etc.) e as etapas de seu cotidiano vividas entre momentos de "bastidor" e subsequente "exibição" pública, lembram demais a elaboração de um espetáculo teatral. Sem falar na configuração espacial bipartida das cerimônias, em que os religiosos "representam seus papeis" (cf. Goffman, 2014) numa espécie de arena ao redor da qual um grupo de espectadores assiste a tudo. Soma-se a tudo isso a abundância musical - através dos cantos e dos ritmos oriundos do uso de vários instrumentos - e a intensa expressividade do corpo, através das diversificadas danças coreografadas com cuidadosa precisão. A expressão da gestualidade dos iniciados nada mais é do que a corporificação de um script composto pela rica cosmologia na qual o rito se estrutura. Como no teatro, a criatividade e o senso estético são explorados ao máximo na tentativa de expressar a marcante experiência dos orixás. 


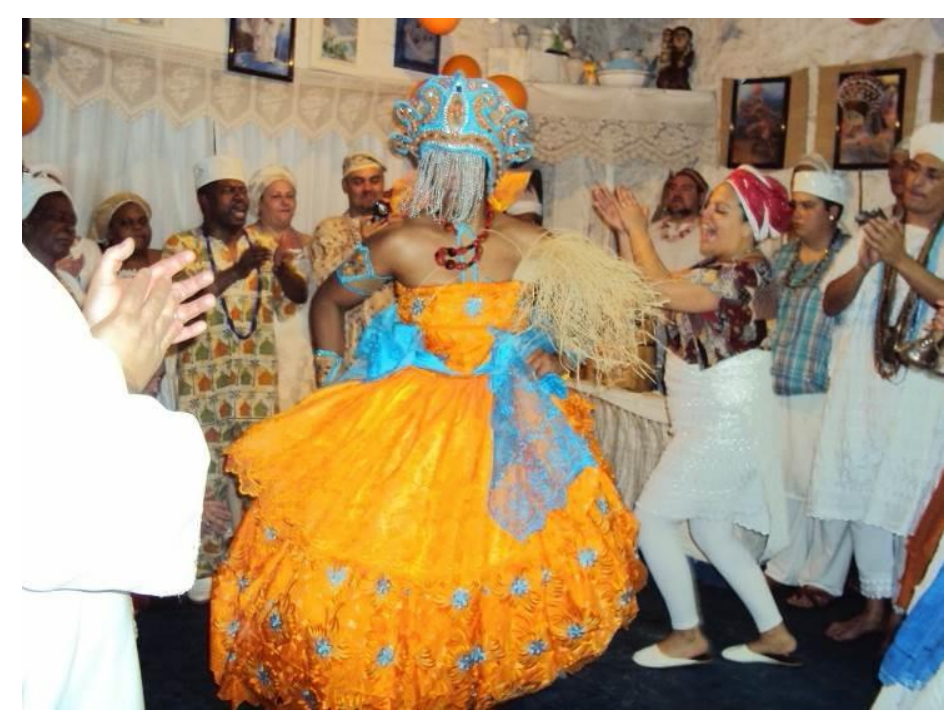

Figura 6: O xirêe-performers e espectadores: dança ritual de Iansã Fonte: Google Imagens ${ }^{\circledR}$

No entanto, como já expliquei anteriormente, na inserção inicial ao estudo dos abiãs, estava longe de minhas intenções a tentativa de demonstrar esta dimensão da realidade religiosa através das observações e entrevistas que eu realizava. Porém, ao longo da pesquisa, este aspecto do campo foi se demonstrando como extremamente relevante, não apenas nas biografias dos meus interlocutores, mas principalmente no cotidiano dos terreiros que eu observava.

A epígrafe que abre esta sessão é parte de uma das entrevistas que realizei, mas posso informar que inúmeras foram as vezes em que escutei metáforas do mesmo campo semântico, ou sejam, que deixam transparecer o caráter teatral do cotidiano do terreiro. Neste caso, se pensarmos a própria vida social como uma "representação teatral", conforme nos propõe Goffman (2014), o grande "baile dos orixás" seria uma espécie de metateatro desta realidade.

Por conseguinte, acredito que os termos que ouvi como "teatro", "espetáculo", "carnaval", "circo" e "show", sempre faziam menção às possíveis semelhanças estéticas e processuais desses eventos, percebidos por meus interlocutores como bem próximos ao caráter "teatral" de suas festividades litúrgicas.

O continuum entre teatro e ritual proposto por Schechner (1988; 2003; 2011; 2012a; 2012b) é tão factual, que mesmo as elucubrações do senso comum a respeito das festas dos orixás parecem ir de encontro a este princípio teórico. É como se intuitivamente meus informantes tivessem me remetido ao olhar proposto por Schechner $(1988 ; 2003 ; 2012 \mathrm{a} ; 2012 \mathrm{~b})$ a respeito dos rituais como 
performance, no seu sentido mais lato. Até mesmo porque, o grande diferencial da proposição teórica deste autor é justamente não reproduzir a rígida separação entre a "performance ritual (ou drama social)" e a "performance estético-teatral" como havia feito inicialmente Victor Turner (cf. Langdon, 1996; Silva, 2005a; 2007).

Em grande parte dos casos que conheci durante a pesquisa, o "espetáculo" do ritual configurava-se como o primeiro contato de muitos fiéis com a própria religião e, sobretudo, como fator marcante no seu envolvimento subjetivo, transmutado em adesão religiosa posterior. São muitos os relatos colhidos no meu percurso etnográfico, que atestam essa imbricação entre ritual e prazer estético, ou como diria Schechner $(1988 ; 2003 ; 2012 a ; 2012 b)$ entre eficácia e entretenimento:

Ah, é muito lindo! Quem tá de fora acha aquilo maravilhoso! Ma-ra-vi-lho-so! Um espetáculo! E é emocionante de ver. Realmente é emocionante. Você vê...tem pessoas que tem... você consegue captar a energia... tá mesmo com o orixá... entendeu? (abiã Odete)

Em visitas que eu fui, achava muito bonito. Parece um carnaval assim meio que fechado. [...] Eu participei de uma festa [...] me arrepiou! Dali em diante que eu vi: não, não tem jeito! Eu vou ter que ser daqui mesmo. Porque você não se arrepia à toa, você não se emociona à toa. Você não sente vontade de chorá, de gritá, de correr por nada! Então, algum significado tem que tê. Eu achei muito bonito, muito lindo! A gente fica mais batendo palma, mais assim ligado. [...] É como se fosse num circo. Você assiste mais. É lindo vê eles dançando, se expressando. [...] E você acha lindo e gosta de estar ali. Por sê uma coisa assim, muito fantasia. Muita... muito ilustração! (abiã Devanilda)

Todavia é sempre importante destacar, que esta espécie de encantamento como definem meus informantes - em vários casos, pode estar profundamente imbricado com algumas "aflições do espírito" (cf. Fry \& Howe, 1975), ou "marcas dos orixás" (cf. Barros \& Teixeira, 2000) na vida dos frequentadores do candomblé. Geralmente, isto se expressa numa vasta tipologia de desequilíbrios: emocional, físico, financeiro, amoroso etc. Neste conjunto das aflições que levam os indivíduos às modalidades religiosas afro-brasileiras, podemos encontrar também uma espécie de chamado das divindades (cf. Goldman, 1987), que em certos momentos revela-se exatamente no decorrer da festa dos orixás. Ou seja, sob o estímulo sensorial intenso da performance dos filhos-de-santo na dança litúrgica, que é assistida por inúmeros espectadores.

São recorrentes os casos de pessoas que ao visitarem uma festividade do candomblé pela primeira vez, entram em transe sem nunca terem sido familiarizados com os códigos do grupo religioso. Roger Bastide (2001), em suas 
inúmeras incursões etnográficas, identificou esta manifestação como santo bruto, posto que é uma possessão ainda não doutrinada pelos códigos do grupo religioso. Portanto, casos como esses nos relembram o forte impacto que a fruição estética pode apresentar na subjetividade e, portanto, no corpo dos espectadores. Certa vez, a abiã Regina explicava que sua principal motivação para ingressar efetivamente na religião foi justamente o dia em que caiu em transe involuntário no meio da festa. Conforme ela enfatiza em sua fala, no primeiro terreiro que frequentou foi apenas como "espectadora", já que não sentiu no corpo a necessidade real de tornara-se abiã :

Foi por isso que eu aceitei logo tudo, entendeu? Porque na outra casa eu nunca tinha sentido nada, agora lá no pai André eu sinto um monte de coisa, a energia é muito grande, é uma energia muito boa. E se a gente ficá em alfa, como se dizem, né, melhor ainda. (abiã Regina)

Não obstante, percebi que na gramática cotidiana do povo-de-santo, estas metáforas da espetacularidade parecem operar numa duplicidade semântica de acordo com as circunstâncias. Para alguns religiosos, o uso da ideia do teatro associado ao candomblé poderá ser interpretado igualmente como um momento de esvaziamento da veracidade das performances. Sendo assim, fica claro que os adeptos estão atentos a essa dimensão "espetacular" e suas perigosas nuances.

As falas de meus interlocutores transparecem também a inquietação com esta duplicidade que o caráter "teatral" das festividades religiosas pode apresentar. Notamos entre eles um uso positivado da ideia de teatro e outro negativado. No primeiro, exalta-se a beleza e a emoção que emergem da performance, no momento da festa. No segundo, critica-se o perigo da perda da "essência" e da "tradição" que justificam as práticas sócio-religiosas do grupo. Nesta circunstância, o termo "carnaval" reaparece imbricado no aspecto "teatral" pejorativamente:

O candomblé, ele virou meio que um carnaval em algumas casas. Hoje muitos abiãs não são feitos, pelo custo. Porque os pais-de-santo e mãe-de-santo qué embelezá o orixá. E o orixá não precisa disso. [...] Não seria essa fortuna que é hoje, porque querem embelezá! (abiã Afonsinho)

Eu fui pro candomblé porque realmente, louvá o orixá pra mim é uma coisa maravilhosa. É muito bonito mesmo. Emociona! Mas é aquilo, sem teatro! É uma coisa mesmo pura! (abiã Jurema)

Numa ocasião em que conversava com a mãe-de-santo Dora a respeito das 
imagens de alguns candomblés veiculados na internet, as terminologias relacionadas ao carnaval reapareceram em seu discurso, para ilustrar um caráter espetacular pejorativo das correntes práticas nos barracões. A sacerdotisa contoume que o candomblé havia tido um "momento muito absoluto, muito bonito" entre as décadas de 1960 e 1975. Depois disso, segundo ela, muitos valores "tradicionais" haviam se perdido dando lugar à vaidade e muitos interesses materiais:

De oitenta pra cá houve muitas mudanças. Já começaram em setenta. Setenta e cinco pra frente começô mais inovações. Depois que o Dener "fez santo". Ele era um costureiro, estilista. Então, depois da 'feitura' do Dener. Ele aparecia na capa do Cruzeiro, né? De quelế ${ }^{6 l}$, delogum, numa cadeira linda, maravilhosa! Isso deve ter na biblioteca nacional. Isso deve constar lá, com certeza. Depois do Dener o candomblé tomou outro direcionamento. Ficô mais escola de samba! Ficou mais estilista, com notas pra alegorias e adereços, paetês, purpurinas. Foi perdendo a qualidade, a densidade da religião. (mãe-de-santo Dora)

Num discurso que mescla o saudosismo e a crítica, a sacerdotisa começa a elencar algumas personalidades famosas que de certa forma teriam influenciado a subjetividade dos praticantes do candomblé, no tocante a uma maior valorização da estética em detrimento da "tradição". O estilista Dener (1937-1978) e o pai-desanto Joãozinho da Goméia (1914-1971) ${ }^{62}$ são citados por ela como duas pessoas que propagaram em certa medida um caráter "espetacular" do candomblé. Neste momento, o termo adquire uma nuance claramente pejorativa. Ela relembra inclusive a participação deste último no carnaval e em apresentações "folclóricas" onde o candomblé configurava-se como tema central.

Como me explicou cuidadosamente, naquela época, tanto ela quanto seus contemporâneos ficaram bastante incomodados com essa publicização do candomblé sob um prisma, digamos, um tanto "espetacular". De fato, a constante exposição midiática do candomblé através de Joãozinho da Goméia e seu terreiro, levou-o a adquirir a alcunha de "rei do candomblê", embora sua legitimidade

\footnotetext{
${ }^{61}$ Delogum e quelê: colares rituais símbolos da iniciação. Adiante retornaremos ao tema.

${ }^{62}$ Joãozinho da Goméia foi um sacerdote que iniciou sua trajetória religiosa na Bahia e mudou-se para o Rio de Janeiro na década de 1940. Em 1967 participou de uma longa reportagem da revista "O Cruzeiro", na qual sua foto foi estampada na capa acompanhada de mais 26 fotografias exemplificando as vestimentas litúrgicas do candomblé. Ele foi o primeiro pai-desanto a utilizar sistematicamente os meios de comunicação ampliando seu prestígio, autoridade e a visibilidade do candomblé. Suas constantes aparições na mídia da época e sua homossexualidade (cf. Landes, 2002), desafiaram o arraigado conservadorismo dos terreiros da década de 1960. Como destaca Mendes (2014) é lembrado pelo povo-de-santo como o sacerdote que transformou o candomblé em "teatro". Para maiores informações ver: Mendes (2014); Gonçalves \& Lody (2002).
} 
ritual seja contestada até hoje entre muitos adeptos da religião. Para os antropólogos Vagner G. da Silva (2002) e Raul Lody (2002), este sacerdote teria se constituído no melhor exemplo daquilo que Rita Amaral (1998; 2002) havia classificado como o ethos festivo do povo-de-santo, no qual a estética, a festa e o sagrado são inseparáveis. Podemos considerar que Joãozinho da Goméia foi um dos precursores a realizarem performances expressivas do candomblé no espaço público.

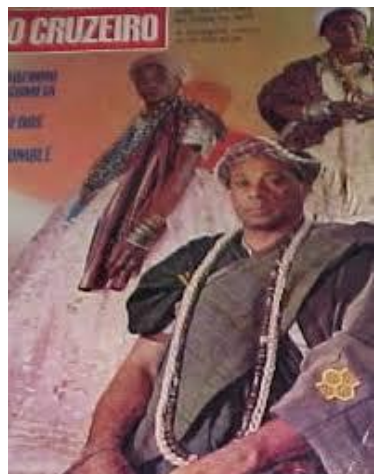

Figura 7: Joãozinho da Goméia na capa de "O Cruzeiro"

Fonte: Google Imagens ${ }^{\circledR}$

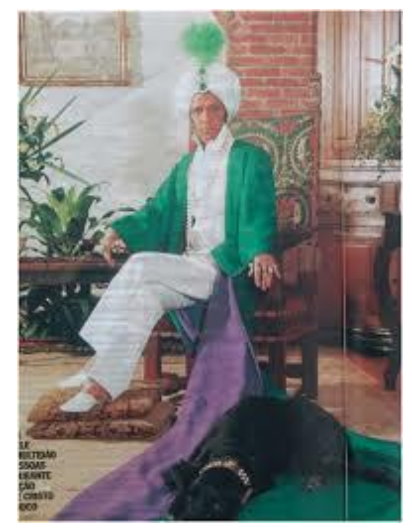

Figura 9: Estilista Dener em "O Cruzeiro"

Fonte: Google Imagens $®$

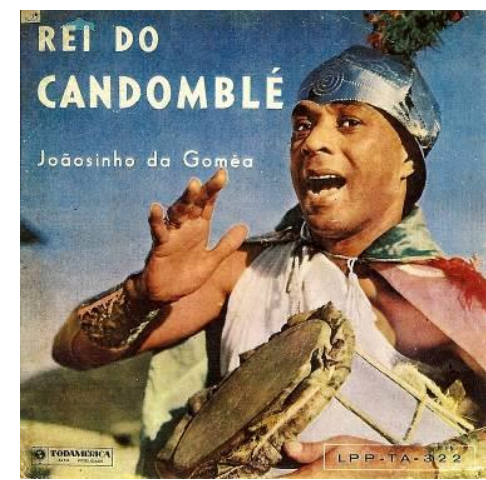

Figura 8: Capa do disco de Joãozinho da Goméia

Fonte: Google Imagens®

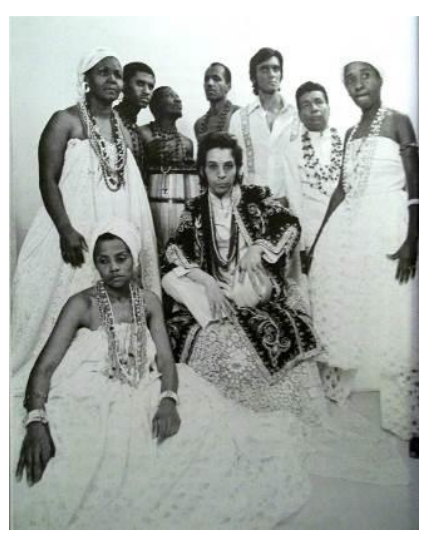

Figura 10: Estilista Dener em

"O Cruzeiro"

Fonte: Google Imagens ${ }^{\circledR}$

Outra observação relevante ainda relacionada à polissemia dos termos "teatro" e "espetáculo" no cotidiano do povo-de-santo, é o uso difundido da categoria $e q u \hat{e}^{63}$, para identificar supostas inautenticidades rituais. O próprio Joãozinho da Goméia constitui um exemplo deste tipo de julgamento exercido pelos peritos da liturgia. É muito comum percebermos entre os fiéis conversas jocosas a respeito de inúmeras situações em que se coloca à prova a veracidade do

${ }^{63}$ Equê ou ekê é um termo oriundo do iorubá èké que pode ser traduzido como mentira. Ver: Cacciatore (1977). 
transe dos indivíduos.

Certa vez, numa entrevista com o ebôme Ronaldo do terreiro de pai Carlito, descobri uma dessas histórias. Sem ser iniciado, seu amigo Paulinho fingia o transe de orixá durante as festas do candomblé, apenas para poder adentrar os "bastidores" dos templos com a intenção de catar $^{64}$ segredos do culto. Segundo Ronaldo, o equê de Paulinho era tão verossímil, que em todos os barracões que ele visitava, vestiam ${ }^{65}$ seu suposto orixá para dançar. De acordo com sua descrição humorada da situação, o equê era composto de uma perfeita reprodução das coreografias litúrgicas. Com esta artimanha o prazer da dança e o acesso parcial aos "bastidores" tornava-se momentaneamente possível. Discordando completamente do amigo, Ronaldo atribuía isso a uma empolgação que leva boa parte dos abiãs hoje a quererem se iniciar:

Acho que é pela beleza do salão. De vê aquela festa. Aquela alegria. [...] O que eu chamo do show. Que eles não veem o que tá atrás. Só o "palco" lá. Os orixás muito bem arrumados, paramentados, dançando felizes. [...] Ele qué o bonito. Ele qué "ferver", ir pras festas, participá! (ebôme Ronaldo)

Há no candomblé de maneira geral, uma etiqueta ritual a respeito das danças, bastante rígida com relação aos abiãs. Logo no início do abianato é ensinado que, mesmo o orixá dando sinais de sua manifestação durante as festas públicos, jamais o abiã poderá desempenhar qualquer performance solo antes de sua feitura. Nas festividades do candomblé é comum vermos a cena na qual os abiãs são retirados do salão ao entrarem em transe. Sendo assim, todas as vezes que bolam ou "passam mal", os postulantes são levados imediatamente a um cômodo diferente daquele onde os orixás dos já iniciados são vestidos. Na alusão às terminologias teatrais, poderíamos dizer que este seria um "camarim" dos orixás, ou seja, um espaço de transição da performance, reservado aos iniciados. Portanto, frequentadores como o abiã Paulinho, constituem o típico fura roncó ${ }^{66}$,

\footnotetext{
${ }^{64}$ Catar é uma expressão utilizada pelos religiosos para designar a aquisição de conhecimento de modo não oficial, indireto, de soslaio. Devido a grande dificuldade de acesso aos saberes rituais que são transmitidos sob uma rígida hierarquia de idade iniciática, é preciso estar de olhos sempre atentos para catar alguma informação.

65 É frequente no candomblé, vestir o religioso em transe com roupas litúrgicas próprias dos orixás, como numa espécie de figurino ritual. Estas vestimentas são chamadas de axós. Em alguns casos, quando não há troca completa do traje ritual, o adepto é envolto com uma tira de pano que pode variar de cor e largura (atacã). Esta atitude marca a diferenciação entre a pessoa e o orixá manifestado, funcionando como uma espécie de "máscara" vestida pelo performer. Em relação ao vestuário litúrgico no candomblé, ver os estudos de Lody (2001); Souza (2007).

${ }^{66}$ Fura roncó: expressão nativa para indicar aqueles que burlam as fronteiras que resguardam os
} 
pois acessa espaços jamais permitidos aos "estranhos", principalmente quando não iniciados.

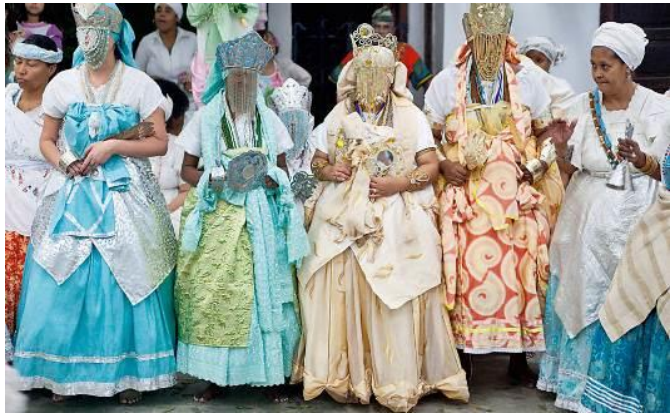

Figura 11: "Espetáculo" dos orixás

Fonte: Google Imagens®

No entanto, a percepção desta dimensão "espetacular" das religiões afro-brasileiras tem sido retratada também na literatura especializada há bastante tempo. O caráter "teatral" das festas públicas do candomblé esteve presente direta ou indiretamente em muitas incursões antropológicas e sociológicas de muitos estudos no decurso do século XX (Rodrigues, 1935; Pierson, 1942; Herskovits, 1943; Ramos, 1971; Bastide: 1971; $1973 ; 2001)^{67}$.

Mesmo não sendo o prisma de análise de boa parte desses pesquisadores, a aguçada expressividade estética desses cultos raramente deixou de ser notada e relatada nas etnografias. De maneira muito breve, poderíamos destacar algumas passagens bastante elucidativas disto nos estudos sobre o candomblé. Independentemente dos posicionamentos teóricos de cada um dos autores em suas respectivas épocas, procurarei destacar etnografias que evidenciaram os elementos "teatrais" dos rituais públicos do candomblé.

Entendo esta dimensão teatral, por um lado, no tocante ao intenso apelo estético dos eventos, e por outro, da sua estrutura composta dos binômios: atoresespectadores, e palco-bastidores. Da mesma maneira, considero o encadeamento temporal dos eventos - início, clímax e desfecho - como um traço fundamental desta dimensão que considero dramatúrgica. O ludismo e o "desempenho de papeis na interação face a face" (cf. Goffman, 2014), que os rituais públicos do candomblé proporcionam, também devem ser considerados neste prisma.

Nina Rodrigues (1935), parece ter sido um dos precursores a registrar a duplicidade estrutural do candomblé entre: um "culto doméstico", com pequenos

segredos e espaços secretos do culto. O roncó é o cômodo no qual ocorre a reclusão iniciática. Sendo um espaço vetado aos não iniciados, adentrá-lo sem passar pela iniciação constitui um verdadeiro tabu. Por extensão, adentrar os espaços privados do terreiro sendo um abiã constituiria uma infração grave. Portanto, o abiã que age dessa forma recebe a alcunha de fura roncó.

${ }^{67}$ Datas referentes às edições que consultei. 
oratórios e capelas residenciais; e um "culto exterior", com uma "forma complexa, brilhante e ruidosa" (Rodrigues, 1935, p. 61) que se desenvolvia de maneira acelerada pela Bahia. Por estar imerso na ideologia racista e evolucionista típica de seu tempo, interpretou as danças e os cânticos em profusão desta modalidade pública da religião, como um traço supersticioso e fetichista das populações negras. As danças e os cânticos litúrgicos que constituíam o agente principal do transe foram associados a estados patológicos e a uma extravagância dita "primitiva".

Porém, parte de sua grande contribuição etnográfica está no registro desta dimensão espetacular que estava no âmago da religião desde então. Ao longo do texto, fruto de uma extensa vivência nos terreiros baianos de sua época, ele destaca o papel crucial das "danças sagradas" e do "batucagé" (cf. Rodrigues, 1935, p. 160), ou seja, das coreografias das iniciadas e dos cantos. Suas notas etnográficas sobre os terreiros de candomblé da Bahia deixam claro a estreita relação entre religiosidade de matrizes africanas e festa:

Chamam-se candomblés as grandes festas públicas do culto yorubano, qualquer que seja a sua causa. Entre os motivos principaes, figura como já vimos, a iniciação ou feitura de santo. Mas, uma vez iniciado, todo filho-de-santo contrai a obrigação moral de festejar o seu santo, com pompa variavel segundo os recursos de cada um, nos anniversarios da iniciação. (Rodrigues: 1935: 141) ${ }^{68}$

No seu rastro, Arthur Ramos (1971), médico e etnólogo que se dedicou a um profícuo estudo das ditas culturas negras nas Américas, também destacou o caráter "espetacular" dos candomblés. Porém, como um exemplar discípulo do pensamento evolucionista de Nina Rodrigues, irá ressaltar uma graduação de "espetacularidade" como fator de maior atraso cultural nos candomblés de modalidade banto. Ele creditava uma maior "espetacularidade" nos cultos originários das etnias Banto, a uma menor resistência desses grupos às influências estrangeiras. De certa forma, esta suposta superioridade cultural sudanesa também será reforçada posteriormente em alguns estudos de Roger Bastide (1971; 1973).

Outro estudo bastante ilustrativo desse caráter "espetacular" do candomblé foi realizado pelo sociólogo norte americano Donald Pierson (1942). Apesar do foco de sua reflexão ser a realidade social das populações negras no Brasil, sua obra "O candomblé da Baía" (1942) também nos oferece alguns sinais da

\footnotetext{
${ }^{68}$ Respeitei neste trecho a grafia da obra original.
} 
estrutura "teatral" do candomblé. Pierson (1942) identifica as filhas-de-santo iniciadas nos terreiros com o uso do termo "dansarinas cerimonias"69 (Idem, 1942, p. 18-19) ressaltando o papel central da expressão estética do culto. Ele destaca a maneira como a música e a dança conduzem todo o ritual público, no qual são as "dansarinas cerimonias" que desempenham no uso do próprio corpo a performance executada diante de uma plateia diversificada.

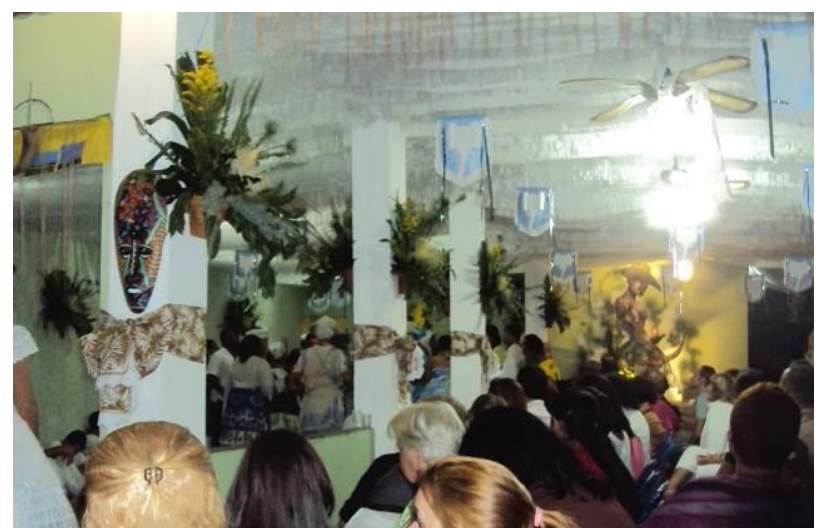

Figura 12: Espectadores assistem a performance ritual Fonte: Acervo da pesquisa

Na configuração arquitetônica dos terreiros ele destaca o barracão como sendo "lugar sagrado da dança" (Idem, 1942, p. 13). Pierson ainda chama a atenção para "a rígida separação dos espectadores de acordo com o sexo", em que "os homens ocupam sempre os assentos à esquerda dos tambores, as mulheres os da direita" (Idem, 1942, p. 20-21). O espaço é composto de aposentos específicos para as trocas de vestuário das "dansarinas cerimonias" quando em "estado de santo", compondo assim uma espécie de "bastidores" do "espetáculo" assistido no salão do barracão. Sua descrição do ritual como "dansa cerimonial” (Idem, 1942, p. 21) deixa entrever a estrutura dramática dos acontecimentos:

Quando, durante a dansa cerimonial um orixá 'chega à cabeça' de uma filha de santo, depois de passado o primeiro transe violento, ela deve executar a dansa sagrada de seu orixá, depois do que é levada do barracão até o pegi, tendo o cuidado ao se afastar de manter o rosto sempre voltado para os tambores. Em um quarto especial ela é então vestida com os trajos de cerimônia consagrados a seu orixá e com sua insígnia sagrada ela volta ao barracão para executar durante horas as dansas dedicadas a seu orixá. (Idem, 1942, p. 21) ${ }^{70}$

Outro observador atento da dimensão "espetacular" do candomblé foi o

\footnotetext{
${ }^{69}$ Respeitei neste trecho a grafia da obra original.

${ }^{70}$ Idem.
} 
americano Melville J. Herskovits, em seu texto "Pesquisas Etnológicas na Bahia" (1943), no qual ressalta a presença dos elementos estéticos e lúdicos nas cerimônias festivas do candomblé. Como afirmou Bastide (2001), este antropólogo que chegou ao Brasil em 1942, teve o mérito de recolocar "a vida religiosa no conjunto da vida social ou da vida cotidiana do negro brasileiro" (Bastide, 2001, p. 23). Na sua interpretação funcionalista, a capacidade de desenvolver os valores estéticos de seus frequentadores passa a ser uma das importâncias sociais das festas em louvor aos orixás. Em sua opinião, mesmo os espectadores "leigos" que não dominam a gramática simbólica que sustenta a performance apresentada no terreiro, podem se beneficiar com a própria fruição estética do evento:

Cumpre ainda o candomblé outra necessidade, criando valores estéticos. Esta função estética por vários meios se exprime e, para os não-iniciados, deriva principalmente das grandes festas públicas a que ocorrem para apreciar. Aí o canto, acompanhado pelos atabaques, agogôs, cabaças, e outros instrumentos de percussão, as danças, as vestimentas, a grande aglomeração de espectadores, tudo se combina para proporcionar o prazer e a tensão emotiva de que, em outras culturas, se encarregam o teatro e o cinema, os concertos e a ópera. (Herskovits, 1943 , p. 22)

Mesmo que cada um desses autores esteja observando ocorrências do candomblé circunscritas em épocas e abordagens epistemológicas específicas, os traços desse apelo estético das festas do candomblé perpassam as gerações. É justamente a observação empírica dos festejos aos orixás nos terreiros, que nos fazem ter a certeza da "atualidade" desta condição espetacular da religião.

Roger Bastide $(1971 ; 1973)$ em seu profícuo estudo sobre as religiões afrobrasileiras, contribuiu de duas maneiras no tocante a este aspecto dos cultos. Primeiro, ele também nos oferece alguns relatos desta dimensão estética determinante na identidade das modalidades religiosas em questão. Inclusive, suas observações versam sobre um crescente excesso dos elementos estéticos em tipos menos "puros" das religiões de origem africana, como no caso das macumbas urbanas e dos candomblés de caboclo. $\mathrm{O}$ autor é bastante enfático ao se referir aos "falsos candomblés" e as "falsas macumbas" (Bastide, 1971, p. 321) feitas para explorar turistas e brancos supersticiosos. Mas de qualquer maneira, na vertente nagô - considerada por ele como mais "pura" - esta dimensão "espetacular" está igualmente presente, porém em uma escala mais "fiel" às culturas africanas originárias, segundo seu crivo. Como ele destaca, "o prestígio do candomblé é 
função da beleza da festa, da disciplina que aí reina, da abundância de alimentos que são oferecidos, do esplendor do cerimonial” (Bastide, 1971, p. 320).

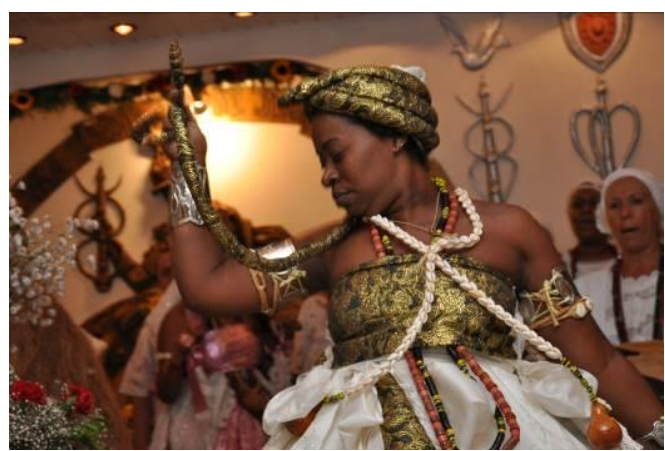

Figura 13: Performance do adepto-orixá: Oxumarê

Fonte: Google Imagens ${ }^{\circledR}$
Como ressalta Eufrazia C. M. Santos (2005) em sua abordagem sobre a "espetacularidade" do candomblé, este foi um dos poucos estudiosos a realizarem uma analogia entre o candomblé e o teatro em momentos diversos de sua produção acadêmica (Santos, 2005, p. 118). E, diferente de muitos intelectuais que o

precederam, ele não abordou o culto público do candomblé por um viés caricatural. Bastide acreditava que o fascínio dos pesquisadores pelas cerimônias públicas do candomblé poderia ceder lugar a um interesse maior pelos aspectos domésticos do culto, favorecendo assim um melhor entendimento desse sistema religioso. E, no estudo da faceta cerimonial pública, deveriam ser extintas de vez as abordagens positivistas e evolucionistas.

Sua segunda e valiosa contribuição estaria relacionada a um novo entendimento da possessão no candomblé, que até então havia sido sempre interpretada como marca patológica dos negros. Para ele, o cair no santo era um fenômeno de natureza psicossocial, no qual a personalidade do filho-de-santo é metamorfoseada no ritual. O que de alguma forma nos remete à abordagem de Schechner sobre a liminaridade envolvida na performance ritual, como veremos adiante. Consecutivamente, o fenômeno da possessão na visão de Bastide pode ser comparado "a um jogo litúrgico que mais se aproxima da representação teatral que das crises de loucura recorrentes nos hospitais psiquiátricos" (Santos, 2005, p. 119). É justamente este prisma de análise proposto por Bastide (2001) que contribui para nossa argumentação a respeito da dimensão teatral do candomblé:

O transe religioso está regulado segundo modelos míticos; [...] A configuração das danças tende para o teatro, isto é, para a representação de certas cenas míticas com vários personagens. E então os personagens em transe interferem uns com os outros, há como que um diálogo de mímicas. [...] Esse caráter teatral do transe religioso poderia levar o leitor a imaginar que em geral é ele antes simulado que verdadeiro. [...] Essa impressão, no entanto seria falsa. O transe é muito real. [...] O êxtase é de fato real. (Bastide, 2001, p. 189-192)

Compreendendo o transe como representação mítica através da 
corporalidade dos filhos-de-santo, passamos a pensar em sua estrutura processual de aprendizado e treinamento, como ocorre na representação teatral. O processo ritual iniciático da "feitura" representa este momento de transmissão direta desses códigos gestuais que transfiguram mitos em pantomima. Como afirma Goldman (1987), pela perspectiva das teorias dos rituais, anulam-se os modelos biologizantes e psiquiatrizantes que desproviam o transe de significado ritual.

No rol dos estudos que privilegiaram diretamente a dimensão "espetacular" das festas do candomblé, destaca-se a abordagem ímpar de Rita Amaral $(1998 ;$ 2002). Assim como os outros autores supracitados, ela também sublinha a relevância das formas artísticas como a linguagem preponderante das cerimônias públicas do candomblé.

Realizando uma analogia entre o teatro e as festas dos orixás, sua abordagem destaca o caráter de drama ritual do xirê. Traduzindo este termo como festa ou mesmo a expressão "vamos dançar” (cf. Prandi, 1996, p. 21), ela demonstra como os temas mitológicos são encenados pelos filhos-de-santo através de uma gestualidade extremamente padronizada na performance do estado de orixá ou estado de santo. Além de seu aspecto dramático, o momento do xirê também opera como uma espécie de vitrine da hierarquia e dos valores que compõem o ethos do povo-de-santo. Este é o momento em que religiosos e visitantes encontram-se para festejar, desempenhando seus papeis num jogo lúdico de cantos, danças e figurinos. Além do xirê refletir mimeticamente o corpus cosmológico que sustenta o imaginário da comunidade litúrgica, ele também proporciona entretenimento aos visitantes, que não se encontram efetivamente inscritos no sistema de saberes iniciáticos do grupo. Para ela, o "espírito festivo" constitui traço marcante do que identificou como ethos do povo-de-santo:

[...] a festa também assume, muitas vezes, o caráter de 'lazer', de espetáculo a que se vai no fins-de-semana e do qual é possível fazer parte, seja apenas assistindo, dançando na assistência, seja aproximando-se, aos poucos, da religião. Por ser o momento síntese de tudo que o povo-de-santo pode apresentar publicamente em termos de imagem da religião, para a assistência à festa é não só um verdadeiro espetáculo, de estética ímpar, mas também uma "vitrine" da alegria, do ludismo, da sensualidade e beleza vividos pelos adeptos dessa religião. De seu estilo de vida. (Amaral, 2002, p. 55-56) 


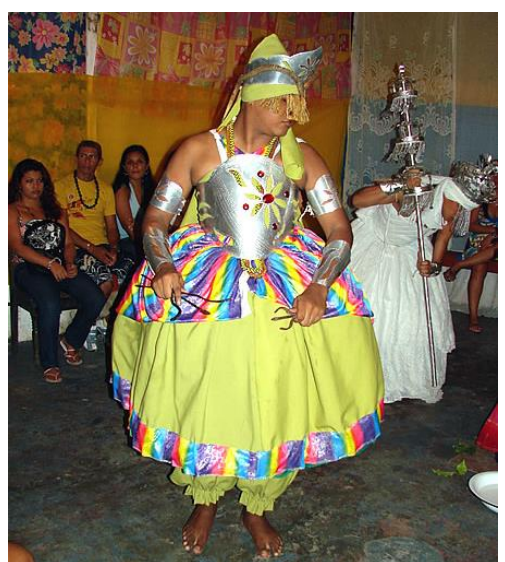

Figura 14: Performance ritual: performers e espectadores Fonte: Google Imagens ${ }^{\circledR}$

Na abordagem de Rita Amaral (1998; 2002), a perspectiva do público que apenas assiste às festas, é percebida como de grande importância, na medida em que revela um transbordamento do sentido da performance ritual para sua relação com a sociedade mais ampla. Assim, a audiência leiga vivencia o xirê enquanto um verdadeiro "espetáculo", porém os religiosos o percebem na sua dupla dimensão de entretenimento e religiosidade. Na performance pública em formato de festa, o candomblé pode oferecer à sociedade a imagem que tem de si mesmo, ressaltando elementos como a beleza e a alegria, em contraste com as imagens estigmatizadas do imaginário dos que não o conhecem "de perto" e "de dentro" (cf. Magnani, 2012).

No tocante a esta interlocução dos terreiros com o espaço público de uma metrópole moderna como o Rio de Janeiro, Marcia Contins $(2015 ; 2016)$ analisa a maneira como o crescimento e a visibilidade das igrejas pentecostais e neopentecostais na paisagem da cidade, tem levado os religiosos de matrizes africanas a reformularem muitas de suas práticas. Com a profusão de igrejas neopentecostais e carismáticas, somada a uma maior transitividade religiosa no contexto plural da cidade, alguns templos de umbanda e candomblé tem desenvolvido novas performances, visando uma maior interação com o grande público, para além dos limites do território religioso.

Ao longo de sua argumentação, a autora refere-se ao seu trabalho etnográfico em terreiros do subúrbio e da zona oeste do Rio de Janeiro, observando que "hoje são as diferentes casas de candomblé e umbanda [...] que privilegiam a relação com o mercado, com a universidade e com os movimentos negros" (Contins, 2016, p. 4). Exemplificando algumas destas inovações em consequência do diálogo destes terreiros com múltiplas performances religiosas que se proliferam na cidade, Contins $(2015 ; 2016)$ cita as ampliações arquitetônicas

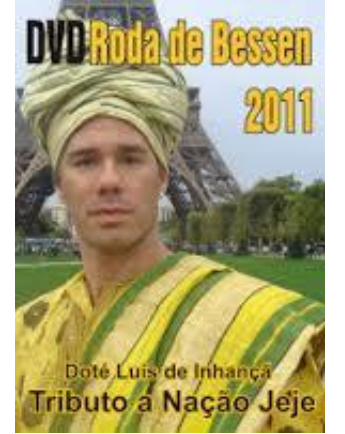

Figura 15: Capa de DVD com filmagens do xirê

Fonte: Google Imagens ${ }^{\circledR}$ 
dos templos afro-brasileiros e a venda de CDs e DVDs com conteúdos rituais transformados em "espetáculo".

Um dos estudos de caso narrados por ela é o de um terreiro no bairro de Anchieta, em que as festas ocorrem num enorme salão composto de farta audiência. Contins $(2015 ; 2016)$ chama a atenção para a ampliada dimensão e compartimentação dos espaços do templo, numa alusão às estruturas monumentais das igrejas neopentecostais, que se destacam na paisagem urbana atualmente. De uma espécie de "bastidor da casa", saem os adeptos ensaiados e paramentados para executarem as danças rituais que serão filmadas por um dos membros do grupo religioso. Após a filmagem, o pai-de-santo distribui o material midiático nas diversas casas de artigos litúrgicos afro-brasileiros do Mercadão de Madureira. O caso deste pai-de-santo, que também é apresentador de programas em rádio e TV, exemplifica bem as reformulações identitárias dos religiosos, frente às novas formas de convivência no espaço da metrópole:

Na medida em que esse acesso ao sagrado se dá no universo de uma grande metrópole moderna, as práticas tendem a assumir, para além de sua forma ritual, o caráter de "espetáculos", em razão mesmo de atenderem a uma clientela que se caracteriza por seu elevado índice demográfico. [...] A utilização do espaço da cidade pelas diferentes religiões proporciona, assim, novas percepções sobre o fenômeno religioso, redefinindo as diversas formas de apropriação desse espaço por meio da experiência religiosa e de performances relacionadas às religiões. (Contins, 2015, p. 81)

Entretanto, esta propagação das performances dos religiosos afrobrasileiros no espaço público, apresenta também outra versão de caráter não "espetacular", ou seja, através da ampla oferta de palestras, cursos e programas midiáticos sobre a cultura africana e afrodescendente. Essas atividades culturais são oferecidas por indivíduos que apenas em alguns casos são praticantes efetivos das religiões de matrizes africanas.

Como destaquei na introdução deste estudo, a própria maneira que utilizei para iniciar minha inserção no campo está profundamente relacionada com este maior diálogo que os terreiros têm estabelecido com o espaço público. Minhas formas de acesso aos informantes desta pesquisa exemplificam a conexão entre o que denominei de circuito cultural e circuito religioso. Unindo ambas as pontas deste percurso, teríamos configurado um circuito do povo-de-santo, com suas novas performances na cidade, para além das festas públicas nos barracões. Destaco que, uso o termo circuito como uma categoria que: 
[...] une estabelecimentos, espaços e equipamentos caracterizados pelo exercício de determinada prática ou oferta de determinado serviço, porém não contíguos na paisagem urbana, sendo reconhecidos em sua totalidade apenas pelos usuários. (Magnani, 2008, p. 45)

Portanto, todas as minhas relações interpessoais no campo foram iniciadas em espaços não religiosos, como museus, universidades e centros culturais. Meu trajeto se deu das salas de aulas de cursos relacionados ao conteúdo cultural afrobrasileiro rumo às casas de axé. Isto não significa dizer que todos os sujeitos envolvidos nesta pesquisa frequentaram estes eventos culturais, mas que cheguei até eles a partir de relações iniciadas no circuito cultural afro-brasileiro.

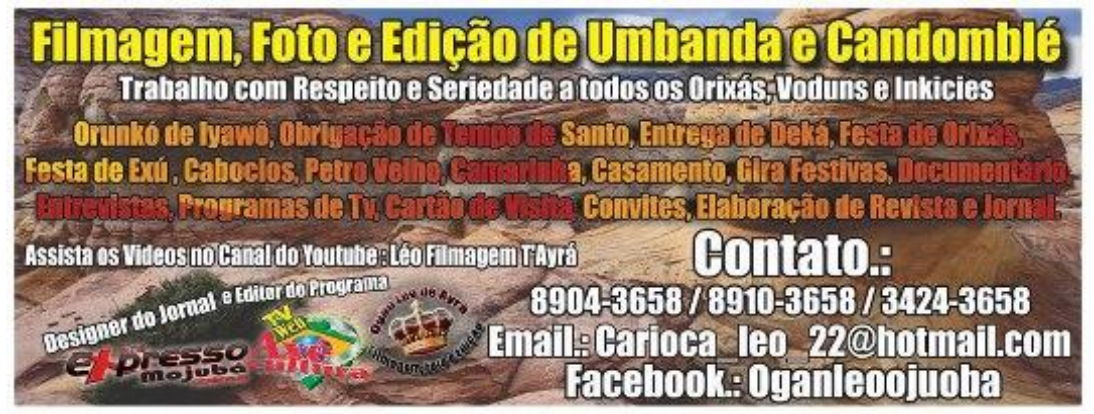

Figura 16: Divulgação de serviços para performances religiosas

Fonte: Google Imagens ${ }^{\circledR}$

Nestes espaços de socialização, muitos adeptos aproveitam para divulgar as festividades de seus terreiros, distribuírem seus cartões de visitas, e se atualizam sobre os últimos acontecimentos do candomblé. Vê-se então, a formação de uma espécie de rede, em que muitos abiãs aderem na tentativa de adquirir mais conhecimento sobre a religião. Sem dúvida, para além dos livros e das mídias digitais, estes espaços configuram-se com um facilitador da aquisição de saberes numa circunstância em que a hierarquia não intervém neste processo. É a oportunidade dos abiãs e dos já iniciados sentarem lado a lado igualados pela condição de alunos, travando uma interlocução bastante proveitosa para os postulantes à feitura. No papel que lhe cabe de aprendiz, esta é uma chance extremamente atraente e proveitosa.

Cabe salientar também, que vários dos abiãs que entrevistei, pertenciam a terreiros nos quais as lideranças apresentavam programas televisivos, davam cursos de língua e cultura iorubá, e tinham livros publicados sobre o culto. Embora em nenhuma narrativa dos abiãs, isto tenha aparecido claramente como um fator determinante da adesão à comunidade religiosa, não poderíamos 
inocentemente deixar de considerar tais proposições. Estar sob a filiação ritual de uma liderança famosa pode ser tão atraente quanto pertencer a uma casa de axé cuja descendência seja um dos ditos terreiros tradicionais da Bahia. Afinal, prestígio e legitimidade são duas preocupações centrais na "carreira" religiosa de qualquer iniciado no candomblé. Esta lição-de-coisas é rapidamente aprendida por qualquer visitante que decida sair da audiência para atuar como abiã no “espetáculo" dos orixás.

\section{3}

\section{"Senti meu coração bater muito forte. Quero ficar aqui!": da "plateia" ao "palco" na dança dos orixás}

Esse território - esse terreiro - não é apenas uma extensão sagrada entre outras, mas também a base invisível de uma intensa atividade física e mental que associa todos os sentidos do corpo e todos os modos de expressão - gestualidade, mensagem sonora, odores, perfumes, ritmo do tambor, a 'música do transe', segundo Rouget. Uma linguagem sem escrita. (Jean Duvignaud, in: Bastide, 2001, p. 341)

Candomblé $e^{71}$ é uma palavra que entre o povo-de-santo é bastante polissêmica. Inicialmente relacionada ao sentido de dança, foi aos poucos assumindo a acepção de religião. Sendo uma religião que tem no seu âmago litúrgico uma expressão dançada bastante padronizada, acabou ficando mais conhecida justamente pela terminologia referente a esta performance ritual. No candomblé, a dança é o culto, e vice versa. É por meio dessa performance que os homens atingem o objetivo mais esperado: estar em interação direta com as divindades. Por conseguinte, os locais onde essas coreografias sagradas ocorrem, acabaram por incorporar também a denominação do culto. Então, o mesmo termo passou a ser utilizado para se referir ao local da dança, ou local de culto. Por isso,

\footnotetext{
${ }^{71}$ Há diversas especulações a respeito da origem do termo candomblé para designar uma das modalidades das religiões de matrizes africanas no Brasil. Edson Carneiro (2008) acredita que a expressão grafada desta maneira seja uma imposição externa ao culto. Em suas extensas pesquisas etnológicas, ele identifica o vocábulo "candombe" sendo usado por negros deportados do Brasil para Buenos Aires como uma referência aos atabaques e às danças executadas ("al tamboril africano"). Segundo o autor, "o e (aberto) do final da palavra, que parece angolense, talvez seja o e (fechado) que comumente se acrescenta às sílabas finais da frase nas línguas sudanesas, modificado pela prosódia baiana que o prefere (sapé, Tieté, roléta)" (Carneiro, 2008, p. 12). A grande dúvida seria a inclusão do $l$ e do $r$, formando os grupos consonantais $b l$ e $b r$ inexistentes nas línguas sudanesas e bantos. Cabe ainda destacar que em diferentes regiões do Brasil há outras denominações para as modalidades religiosas de matrizes africanas (ex: em Pernambuco, "xangô"; no Maranhão, "tambor de mina"; no Rio Grande do Sul, "batuque" etc.).
} 
podemos facilmente ouvir muitas vezes: "eu sou do candomble”, "vou assistir um candomblê", ou mesmo "aqui é o meu candomblé".

Estando a própria denominação da religião imersa na ideia da dança - que neste estudo entendo como performance (cf. Schechner, 2012a; 2012b) - não há como não perceber sua extrema relevância como o símbolo fundamental desse grupo religioso. Por esta razão, poderíamos dizer que ela constitui um dos principais símbolos do candomblé, e como tal, é o elemento capaz de armazenar todos os significados formulados pelos fiéis na sua visão de mundo. Esta função sintetizadora dos símbolos religiosos é explicada por Geertz (2013 p. 93-94):

Os significados só podem ser "armazenados" através de símbolos [...] Tais símbolos religiosos, dramatizados em rituais e relatados em mitos, parecem resumir, de alguma maneira, pelo menos para aqueles que vibram com eles, tudo que se conhece sobre a forma como é o mundo, a qualidade de vida emocional que ele suporta, e a maneira como deve comporta-se quem está nele. Dessa forma, os símbolos sagrados relacionam uma ontologia e uma cosmologia com uma estética e uma moralidade: seu poder peculiar provém de sua suposta capacidade de identificar o fato com o valor no seu nível mais fundamental, de dar um sentido normativo abrangente àquilo que, de outra forma, seria apenas real.

Ao interpretar a religião como um sistema cultural, Geertz (2013) salienta o papel que os símbolos exercem de sintetizar o ethos de um povo, que no caso deste estudo, poderíamos relacionar ao povo-de-santo. Ainda compartilhando a visão deste mesmo autor, poderíamos considerar que "o ethos de um povo é o tom, o caráter e a qualidade de sua vida, seu estilo moral e estético" (Geertz, 2013, p. 93). Portanto, no caso em análise, poderíamos apreendê-lo nos momentos festivos em que o terreiro expõe tudo isso como numa vitrine para a sociedade mais ampla. Como ocorre em toda performance, a presença de um público é parte constituinte da qualidade performática que as ações podem adquirir, porque "performar é mostrar-se fazendo" (Schechner, 2003, p. 26). As ações que compõem as performances são sempre apontadas, demonstradas e sublinhas diante de um grupo de espectadores:

$\mathrm{Na}$ arte, o performer é aquele que atua num show, num espetáculo de teatro, dança, música. Na vida cotidiana, performar é ser exibido ao extremo, sublinhando uma ação para aqueles que as assistem. [...] Fazer performance é um ato que pode também ser entendido em relação a: ser, fazer, mostrar-se fazendo. (Schechner, 2003, p. 25-26)

As danças litúrgicas, assim como a composição física e simbólica do terreiro, oferecem pistas para que possamos apreender o ethos característico deste 
grupo. Na visão de Rita Amaral (1998; 2002), trata-se de um ethos preponderantemente festivo. Para a autora, "fica evidente o caráter de sinônimo que o termo candomblé assume para com o termo festa desde os seus primórdios no Brasil" (Amaral, 2002, p. 29, grifos da autora). A participação empírica de qualquer pesquisador neste universo poderá constatar que essa modalidade religiosa organiza festas litúrgicas sistematicamente, a ponto de podermos afirmar que "a própria vida dentro do terreiro pode ser pensada como a permanente produção da próxima festa" (Amaral, 2002, p. 29, grifos da autora).

Toda a estética do templo e as ações desempenhadas em seu interior incluo aqui as danças dos orixás e as tarefas rituais - estão revestidas de uma espessa dimensão simbólica. A configuração deste território-terreiro serve como cenário para o desempenho que cada indivíduo deverá apresentar de seu papel (cf. Goffman, 2014) na estrutura rígida da etiqueta hierárquica. Porém, é no momento da festa pública que todos esses símbolos e papeis encontram-se expostos no mais alto nível:

A festa é uma das mais expressivas instituições dessa religião e sua visão de mundo, pois é nela que se realiza, de modo paroxístico, toda a diversidade dos papéis, dos graus de poder e de conhecimento a eles relacionados, as individualidades como identidades de orixás e de "nação"72, o gosto, as funções e alternativas que o grupo é capaz de reunir. (Amaral, 2002, p. 30)

A intensidade com que as festas em louvor aos orixás são vividas acaba por influenciar profundamente o gosto e a vida cotidiana do povo-de-santo (cf. Amaral, 2002). Por esta razão, podemos tomar estas ocasiões como uma excelente oportunidade de apreender os sentidos do candomblé. Como ficou claro nas biografias de meus interlocutores ao longo da pesquisa, na maior parte das vezes o

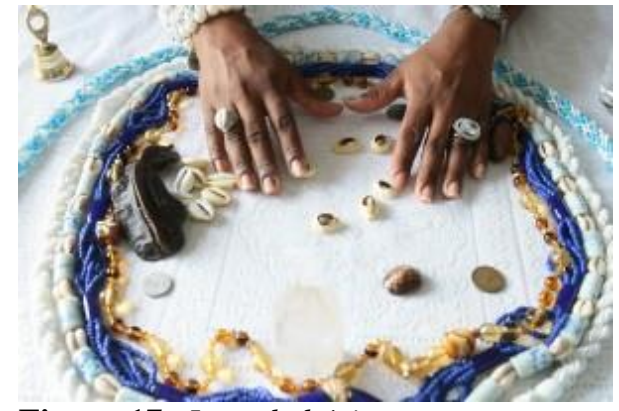

Figura 17: Jogo de búzios Fonte: Google Imagens ${ }^{\circledR}$ primeiro contato dos fiéis com a religião dá-se justamente nas visitas aos dias festivos. Frequentemente percebi no campo que a participação nas festividades acaba provocando nos visitantes o desejo de uma maior aproximação do culto em momentos distintos da festa, como por

\footnotetext{
${ }^{72} \mathrm{~A}$ autora faz menção à noção de nações étnicas africanas, que segundo a classificação identitária dos religiosos, teriam dado origem às diferentes modalidades do candomblé (Jeje-Nagô ou Banto). Este aspecto já foi abordado em nota anterior.
} 
exemplo, por meio da prática oracular do jogo de búzios. Muitas dessas aproximações convertem-se num ingresso efetivo à religião.

Como percebi em meu percurso etnográfico, dentre os múltiplos caminhos que levam um indivíduo ao candomblé, são as festas e o oráculo, os que mais se destacam. Em muitos dos casos, eles estão bastante imbricados. Ao realizar uma consulta oracular o indivíduo poderá passar pelo terreiro no momento de preparação para uma festividade e por isso mesmo, retornar para assisti-la. Da mesma forma, ao participar de uma festa pela primeira vez, as impressões tidas ao longo da experiência podem estimular a procura por uma ajuda oracular $a$ posteriori.

De qualquer forma, indo à festa ou a uma consulta com os búzios, a pessoa estará inevitavelmente travando um contato com um cenário que é totalmente informado por uma rica trama simbólica. Portanto, esta experiência com o espaço do terreiro também poderá ser tão significativa quanto participar de uma festa. Em muitas visitas aos barracões, ouvi abiãs e clientes dizerem que só de passarem por lá, já saíam sentindo-se melhor de suas aflições (cf. Fry, 1975).

Ao pensar a performance como uma ação que se desenrola num espaço determinado para tal, Schechner (2003) destaca a relevância deste para a atuação dos performers, explicando que "um dos significados de performar é fazer as coisas de acordo com um tipo específico de cenário ou plano" (Schechner, 2003, p. 41). Considerando isto, a exegese da configuração simbólica do templo religioso pode nos fazer compreender que ele constitui também um "personagem" com o qual todos os seus frequentadores contracenam, visto que é construído e mantido a partir dos mesmos princípios iniciáticos aos quais os religiosos são submetidos.

Para os religiosos o terreiro é vivo, posto que é fonte de armazenamento e distribuição de $a x e^{73}$. Durante o abianato, uma das lições mais fundamentais é como se relacionar com este espaço e com os atores que nele atuam. Ambas as relações estão submetidas a uma etiqueta ritual bastante estrita. Assim, a

\footnotetext{
${ }^{73}$ Axé: expressão nativa que se refere à ideia de uma força vital e dinamizadora que compõe toda a existência. A noção de axé é fundamental para compreender todas as práticas e crenças dos fiéis do candomblé. Entretanto, este termo é bastante polissêmico entre o povo-de-santo, podendo significar força vital, poder de realização, bons fluídos, o templo religioso, sabedoria, as vísceras dos animais imolados, ou mesmo, uma louvação. Para maiores aprofundamentos, ver: Santos (2002).
} 
performance dos abiãs será construída a partir dos sentidos que a este espaço são atribuídos. Além do que, é a própria qualidade do espaço associada à função da performance que irá determinar se as pessoas irão rotulá-la de ritual ou "teatro", pois "uma performance é chamada de um ou outro por causa do lugar onde ela é performada, por quem, em que circunstâncias e com que propósito" (Schechner, 2003, p. 82).

Contudo, devemos ter em mente que a dança dos orixás, entendida como sinônimo da festa, figura-se como um vértice que une diversos elementos da performance: o cenário, os performers, o script e os espectadores. O cenário é todo o espaço do templo litúrgico, mas o salão do barracão é o próprio "palco" no qual a performance ritual se desenvolve em destaque.

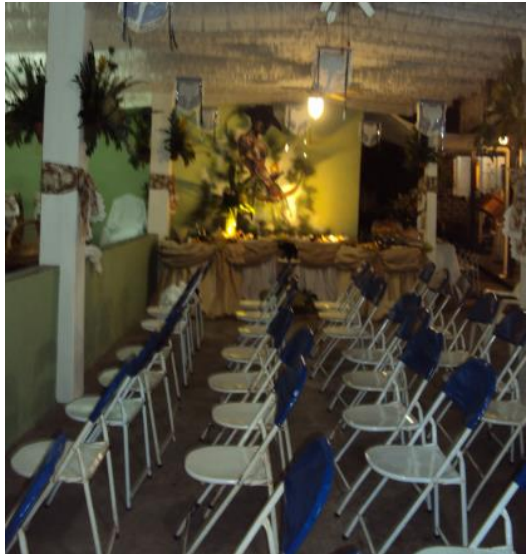

Figura 18: Barracão pronto para a festa Fonte: Acervo da pesquisa

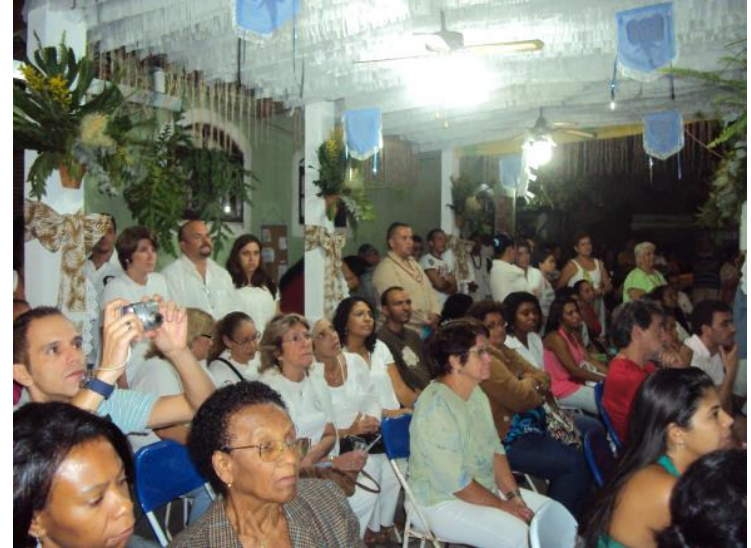

Figura 19: A "plateia” assiste e registra o "espetáculo" Fonte: Acervo da pesquisa

O texto, ou script da performance, está na complexa trama mitológica encarnada nas danças do xirê. Assim, os filhos-de-santo atuam na performance ritual diante de uma audiência composta de amigos, parentes e visitantes. A qualidade da relação entre o público e a performance apresentada é uma problemática também investigada por Richard Schechner (cf. Silva, 2007, p. 67).

Schechner destaca dois tipos de público: "públicos integrais" e "públicos acidentais". No primeiro caso, trata-se de um tipo de público que apresenta certa afinidade eletiva com os performers, partilhando ou não das mesmas redes de relação social. Por outro lado, os "públicos acidentais" são formados por indivíduos sem qualquer tipo de afinidade eletiva com os performers e não demonstram interesse de estreitar laços de relações sociais com o métier em questão. Ao fim da performance, espectadores deste perfil não almejam conhecer os bastidores, nem mesmo cumprimentarem os performers. Como demonstram as 
biografias de meus entrevistados, todos se enquadram no primeiro tipo. Inclusive, foi a partir desta circulação interessada durante as festividades nos terreiros que se tornaram performers.

A circulação de pessoas no terreiro é fundamental para sua sobrevivência material e espiritual, como recorrentemente me informaram mãe Dora e pai Carlito. Dentre as inúmeras explicações exegéticas da configuração arquitetônica e simbólica de uma casa de axé, há basicamente duas versões, em que, ora ela configura-se como uma representação de antigos reinos africanos transplantados para o Brasil (cf. Bastide, 2001), ora como um grande "corpo vivo deitado ao solo quando visto de cima" (cf. Ramos, 2011).

Na primeira concepção mais difundida, o terreiro possui minimamente os principais compartimentos: a) uma região arbórea de equivalência simbólica às florestas africanas provendo os elementos botânicos usados nos rituais; b) o barracão propriamente dito, ou seja, um enorme salão para as festividades, onde ocorrem as performances rituais; c) a cozinha ritual; d) as casas ou quartos dos orixás, locais privados para armazenar as insígnias materiais que os representam; e) o roncó ou camarinha, espécie de quarto para a reclusão ritual iniciática dos neófitos.

Além disso, há banheiros e vestiários para os fiéis. Tudo dependerá das condições econômicas de cada grupamento religioso, que poderá criativamente elaborar novas representações de acordo com os impedimentos espaciais ou econômicos (cf. Silva, 1996). Nesta versão, por exemplo, o peji ${ }^{74}$ de Oxum, simbolizaria a região africana de Oxobô, onde acredita-se que seu culto tenha se originado. Portanto, cada cômodo-altar opera numa alusão simbólica às regiões africanas. Por esta razão, no seu interior, são guardados os assentamentos das divindades cultuadas nessas respectivas regiões, segundo a exegética religiosa. Quando não há espaço apara esta subdivisão em cômodos, prateleiras de madeira ou alvenaria fazem às vezes de fronteiras geográficas simbólicas.

Numa outra versão, a arquitetura do terreiro é compreendida

\footnotetext{
${ }^{74}$ Peji ou sabaji: duas expressões correlatas que os fiéis utilizam para indicar o cômodo no qual as representações materiais dos orixás são reservadas da visão pública. Funciona como uma espécie de quarto-altar no qual os assentamentos dos fiéis são guardados e reverenciados. Em muitas circunstâncias estes cômodos são utilizados também para o momento no qual os filhosde-santo em transe de orixá são vestidos e paramentados com suas insígnias características. Trata-se de um espaço reservado para os membros da comunidade litúrgica. Em certos terreiros, nem os abiãs podem adentrá-lo.
} 
simbolicamente num esquema corporal (Eurico Ramos, 2011, p. 41; Lody, 2013, p. 10) composto da seguinte sequência: a porta de entrada como genitália feminina, nos levaria aos outros órgãos que compõem o "corpo-casa"; próximo à entrada no lado esquerdo, o assento de Exu, representando o pé direito deste grande corpo; no mesmo ponto ao lado direito o assento de Ogum, aludindo ao pé esquerdo do corpo; o roncó seria o útero onde se recolhe o abiã para se tornar iaô; o quarto de Oxum é a barriga; o de Iemanjá os seios; o de Xangô o coração; o de Iansã o pulmão; o de Oxalá o cérebro; o de Oxosse os braços; e o da família Iji (Omolu, Nanã, Ewá, Oxumarêe $)^{75}$ representando a pele desse grande corpo.

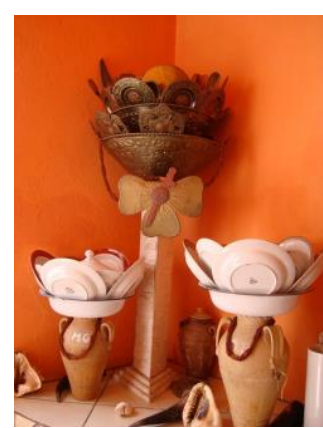

Figura 20: Peji

Fonte: Google Imagens ${ }^{\circledR}$

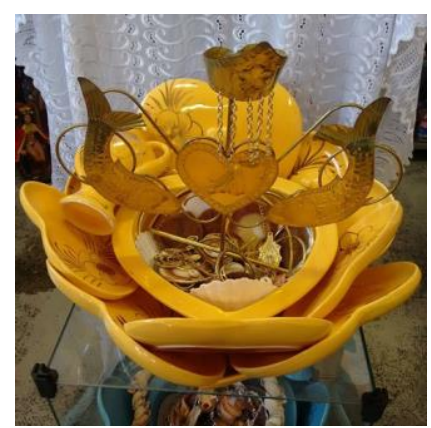

Figura 21: Assento de Oxum Fonte: Google Imagens ${ }^{\circledR}$

O antropólogo Raul Lody (2013a, p. 9-10) ainda completa o sistema dizendo que o ponto central do barracão (o ixé ou ariaxé) representa o umbigo, enquanto que a cozinha é o coração. Nesta formulação simbólica, os religiosos que circulam no interior deste imenso "corpo" (ará) representariam o sangue (ejé) e o sistema circulatório que possibilita a existência da comunidade litúrgica $(e b e ́)^{76}$. É assim que a noção de território para o fiel do candomblé está imbricada numa dimensão simbólica, que durante todo o abianato será obrigatório aprender. Entrar e circular na casa de axé é performar segundo uma gramática gestual aprendida cotidianamente. Na relação cotidiana com estes espaços, o abiã logo aprende a bater nas portas pedindo licença ao sagrado, a tirar os chinelos, a regular a fala e o tom de voz etc. Por isso é importante perceber que a concepção simbólica deste território acarreta uma atuação que é performance também:

\footnotetext{
${ }^{75}$ Exu, Ogum, Oxum, Iemanjá, Xangô, Iansã, Oxalá, Oxosse, Omolu, Nanã, Ewá, Oxumarê: panteão das principais divindades cultuadas nos candomblés de modalidade jeje-nagô visitados nesse estudo. Cada uma delas estaria relacionada a um espaço da natureza e a certos aspectos da existência humana. Por ser um tema extenso e complexo, não será desdobrado neste estudo. Para maiores informações ver artigo exemplar de Claude Lépine (2000).

${ }^{76}$ Ebé: corruptela do iorubá egbe, significando comunidade, sociedade e associação. Por extensão, a comunidade litúrgica do candomblé.
} 
A casa é exatamente um corpo vivo. Por esse motivo, inclusive, quando chegamos da rua, precisamos tomar banho, verter água sobre o corpo e colocar vestes apropriadas, para podermos transitar dentro do ilê - dessa forma, esse grande corpo nos reconhece como parte do ebé e não como um elemento estranho - pois, nesse caso, poderá repelir ou até mesmo 'expulsar o estranho de suas entranhas. (Ramos, 2011, p. 41)

Em muitas circunstâncias, toda essa representação simbólica do terreiro acaba por comungar com diferentes apropriações do território, já que ele também pode configurar como residência dos fiéis. Os dois templos em que realizei uma observação mais sistematizada, configuravam esta tipologia. No caso de mãe Dora, o quintal de sua casa funcionava como a área externa do próprio terreiro. Em dias de festividade, alguns cômodos da sua casa também eram utilizados. O terreiro de pai Carlito, no período inicial da pesquisa estava localizado no quintal de sua casa também. Apenas num segundo momento ele conseguiu construir um novo templo num terreno comprado com a finalidade única de prática religiosa. Portanto, relativo às disposições espaciais dos templos litúrgicos, podemos acrescentar que as fronteiras classificadas como espaço sagrado e público muitas das vezes se interpenetram:

[...] grande parte das casas religiosas de matrizes africanas não são exclusivamente locais de culto, mas são também, simultaneamente, locais de moradia. Nessas casas ou terreiros geralmente vivem não somente a/o chefe religioso e sua família biológica, mas também, ao menos, uma parte dos adeptos da casa. Por essa razão, os terreiros desafiam muitas das classificações e distinções tradicionais, entre elas aquela entre público e privado. (Giacomini, 2013, p. 143-144)

Entrementes, no prisma simbólico do templo entendido como "corpo", quando a comunidade religiosa realiza um processo iniciático de um novo adepto, é comum serem suspensos quaisquer tipos de atendimento para o público em geral. Nesta ocasião o território parece reivindicar sua esfera exclusivamente sagrada. O que reforça a atmosfera de "bastidores", ao percebermos um fechamento do grupo em si mesmo, no qual os rituais partilhados fomentam sua própria coesão. A temática do corpo reaparece metaforicamente projetada no templo, representado como um útero que dará vida ao novo iniciado:

[...] quando uma pessoa é iniciada, toda a comunidade é envolvida e se diz que a ialorixá está grávida. A comunidade religiosa passa a ser um útero que está gerando um ser [...] $\mathrm{O}$ recolhimento envolve toda a comunidade. [...] O iniciando é cuidado como um feto. [...] Depois de 16 dias, se dá o dia do orucó, o dia do nome do iaô, o dia mais importante para a comunidade religiosa, porque vamos apresentar aquele novo filho ao público. Fazemos uma festividade e 
convidamos as pessoas para apresentar o novo membro à comunidade externa. É um parir coletivo. (Moreira, 2007, p. 107)

Porém, é preciso extremo cuidado, pois no tocante às religiões afrobrasileiras, há no seu âmago uma "lógica polívoca e plural", na qual "cada caso é um caso", em oposição a uma ideia de "tradição" engessada (Goldman, 2012, p. 273). Como relembra Goldman (2012), Herskovits já havia chamado a atenção dos estudiosos para este traço ontológico do candomblé, em que a flexibilidade é um "dispositivo compensador", já que "em todas as circunstâncias, as situações alteram os casos", isto sendo "uma das principais causas da sobrevivência dessa instituição complexa a despeito das pressões históricas a que foi submetida" (Herskovits apud Goldman, 2012, p. 273).

Portanto, a praxe da paralisação dos serviços rituais nos momentos iniciáticos de novos filhos-de-santo, pode ser subvertida, como presenciei inúmeras vezes no terreiro de pai Carlito. A quebra deste protocolo colocou-lhe certa vez em conflito aberto com um filho-de-santo que questionava sua atitude. Mas a justificativa do líder religioso era sempre de que infelizmente "as coisas estavam difíceis" e como ele não cobrava o $\operatorname{chão} o^{77}$ (ou a salva) dos filhos-desanto, a clientela era sua primordial fonte de renda. E, no "mercado religioso competitivo afro-brasileiro" (cf. Prandi, 1991), não atender à demanda de um cliente poderia significar além da perda de recursos, o extravio de um potencial filho-de-santo. Como percebi em diversas situações, esta é uma preocupação recorrente de boa parcela dos sacerdotes. Por esta razão que as festas públicas representam também um cartão de visitas dos líderes religiosos e das comunidades litúrgicas.

Uma vez tendo esboçado a estrutura na qual os performers irão atuar, passemos para uma breve contextualização do evento mais esperado pelos religiosos: o xirê. É nessa performance ritual pública, que as atividades litúrgicas atingem sua efervescência, porque "a dança no xirê permite que, através do concreto, chegue-se ao abstrato [...] de forma organizada e também ritualizada, o espectador presencia as imagens físicas, ou melhor, a presença física do orixá

\footnotetext{
${ }^{77}$ Salva ou chão: expressões utilizadas para identificar o valor monetário cobrado pelos sacerdotes por seus serviços religiosos. No geral, cobra-se a salva tanto dos filhos-de-santo quanto dos clientes. Porém, é possível encontrar algumas exceções nas quais os filhos-de-santo não retribuem financeiramente desta maneira formal. Como ressalta Baptista (2007) a expressão ajuda opera como um eufemismo para a transferência de dinheiro para a casa de santo nestes casos.
} 
manifestado" (Zenícola, 2014, p. 75).

Conforme citado anteriormente, o termo xirê em português refere-se à ideia de festa, as grandes festividades dos orixás. Mas como salientou Meyer Fortes (2014) "ritual e dança são os dois componentes de todo festival; o primeiro é geralmente esotérico, a segunda, pública, embora exclusiva" (Fortes, 2014, p. 44). Sendo a face pública do cotidiano ritual dos candomblecistas, é nesta ocasião que identificamos as performances de grande relevância, para pensar o abianato enquanto etapa inicial do longo processo iniciático.

Observando cuidadosamente o contexto da festa, percebe-se que ela configura-se como uma espécie de laboratório para que o abiã capture "técnicas corporais" (cf. Mauss, 2003; 2012) que um dia serão úteis na sua performance depois de feito. Como uma etapa litúrgica pública, o xirê "constitui e revela apenas uma parte da religião, o comportamento social e religioso do grupo, de forma codificada e performática" (Zenícola, 2007, p. 112).

É na expressão do corpo em transe, que as divindades se manifestam na performance ritual do candomblé. Mas toda a gestualidade envolvida nesta expressão possui uma codificação própria e complexa desenvolvida ao longo do tempo pelos religiosos. O conjunto de significados que informam essa gestualidade apresenta uma relação direta com a cosmologia do candomblé pautada nas biografias míticas dos orixás. Assim, “o corpo, morada e receptáculo dos orixás, na dança ritual do candomblé não é construído por gestos individualizados, escolhidos pelo fiel, segundo sua livre criação e interpretação de movimento" (Zenícola, 2003, p. 101). O caráter não espontâneo ou livre das performances do transe no candomblé nos remete a outro conceito valioso proposto por Schechner $(1988 ; 2003 ; 2012 a ; 2012 b)$ é o de "restauração do comportamento".

Ao elaborar sua interpretação a respeito da performance, este autor esclarece que performance significa justamente, "jamais pela primeira vez" (Idem, 2012b, p. 244), ou seja, “da segunda à enésima vez. Performance é 'comportamento repetido"' (Idem, 2012b, p. 244). Por isso, podemos conceber que toda a gestualidade expressa no comportamento ritual estará enraizada num processo anterior de transmissão, aprendizado e treinamento do mesmo.

O performer nestas circunstâncias, é aquele indivíduo que coloca a performance em prática, independentemente de ser um bailarino, um ator ou um 
xamã. É ele quem ativa em seu corpo a restauração do comportamento estabelecido como "tradição", pelo grupo no qual sua performance está emoldurada. Este comportamento possui, portanto, existência exterior a ele, já que figura como saber "esotérico, eficaz, bem guardado" (Idem, 2012b, p. 291). O performer vive um "privilégio especial e um risco perigoso" (Idem, 2012b, p. 291) ao executar sua performance diante do público e de seus pares:

O comportamento restaurado é usado em todos os tipos de performance: do xamanismo e do exorcismo ao transe, do ritual à dança estética e ao teatro, dos ritos de iniciação aos dramas sociais, da psicanálise ao psicodrama e à análise transacional. [...] Quem pratica todas essas artes, ritos e curas acredita que alguns comportamentos - sequências organizadas de eventos, ações roteirizadas, cenas, textos conhecidos, partituras de movimentos - existam separadamente de quem os 'executa': os performers. Graças a essa dicotomia - de um lado, o comportamento, de outro a pessoa que se comporta - o comportamento pode ser armazenado, transmitido, manipulado, transformado. [...] Os performers entram em contato com essas sequências de comportamento ao recuperá-las, recordá-las ou, inclusive, ao inventá-las. (Schechner, 2012b, p. 244; grifos do autor)

Assistindo às performances de transe dos filhos-de-santo feitos, os abiãs tem acesso a um profundo aprendizado da etiqueta gestual do xirê. O sentido lato do termo é festa, mas na acepção mais estrita, se refere às danças realizadas ao redor do ariaxé (ou ixé), através das quais os iniciados entram em transe de orixá e posteriormente executam performances individuais de cada uma das divindades.

Então, este xirê possui dois momentos: no primeiro, uma dança circular em que todos participam sem estar em transe de orixá, enquanto que, num segundo momento, apenas alguns adeptos feitos evoluem em transe de orixá as coreografias sagradas, que expressam a cosmologia do candomblé. Como numa partitura "teatral" o xirê divide-se em atos, que em algumas circunstâncias são entremeados de intervalos para idas ao banheiro ou pequenos lanches. Cada momento está encadeado numa lógica interna, na qual:

[...] segue-se uma ordem preestabelecida, como um roteiro teatral, que reúne os orixás das águas, da terra, da caça, da criação do mundo, numa ordem que atende aos significados prescritos [...] O xirê não é um ritual para aplacar, para temer a Deus ou para apaziguar um deus que se teme, mas para viver a brincadeira de trocar, de partilhar o sagrado em outra dimensão. É um momento especial para se descobrir o corpo, perceber as suas possibilidades, suas habilidades e ganhar conhecimento com as danças litúrgicas [...] É a celebração da pessoa e do personagem que é o orixá. (Lody, 2013b, p. 8-9)

A performance solo do fiel em estado de orixá (o rum do orixá) ${ }^{78}$ jamais é

\footnotetext{
${ }^{78}$ Como já foi explicado anteriormente, na orquestra litúrgica há um terno de atabaques, entre os
} 
autorizada ao abiã, segundo a rígida etiqueta religiosa. Em alguns terreiros, os abiãs permanecem sentados no chão sobre uma esteira de palha, apenas observando a tudo e ajudando com algumas tarefas paralelas como, servir bebidas ou enxugar o chão. Porém, em todos os templos que visitei ao longo da pesquisa, os abiãs participavam ativamente da roda de santo na primeira etapa. Esta é uma ocasião na qual confirma-se o lugar de cada um de acordo com o papel que desempenha na estrutura do terreiro. Neste momento de encontro com todos os membros da comunidade, exercita-se a etiqueta das interações, pois "mais do que um conjunto de representações a cerca do status de cada um, é preciso aprender a se 'situar'. O 'lugar' que se ocupa requer um modo de se dirigir aos outros" (Duccini, 2016, p. 216).

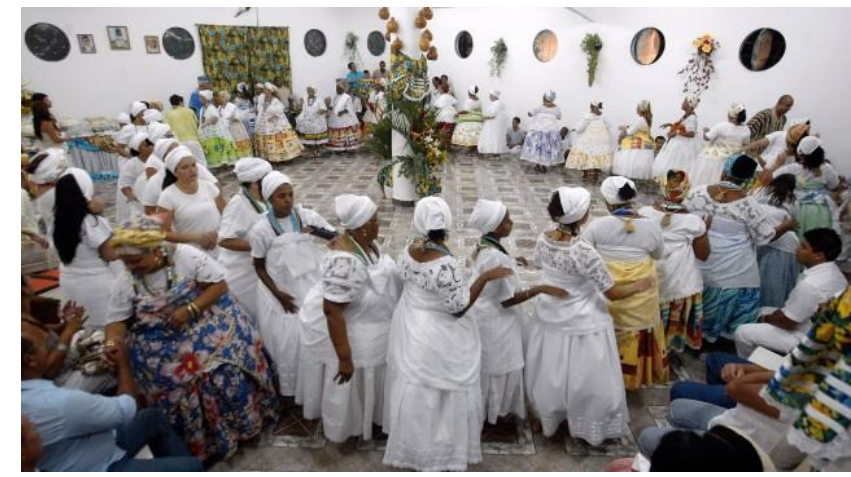

Figura 22: O xirê: roda em ordem hierárquica. Performers e audiência Fonte: Google Imagens ${ }^{\circledR}$

Portanto, o xirê propriamente dito consiste numa longa sequência musical acompanhada por todo o grupo religioso, que dança em forma circular no sentido anti-horário ao redor do centro do barracão. Ao toque dos instrumentos rituais (atabaques, agogôs e cabaças) os fiéis adentram o salão numa grande fila ordenada por idade iniciática. O princípio de senioridade deve ser rigidamente seguido: na frente, os ebômes e as equedes; logo após, os barcos de $i a \hat{o}^{79}$; e, no final da fila, os

quais o maior e mais expressivo chama-se rum. Por extensão, a dança individual de um adeptoorixá no xirê é chamada também de rum. Diz-se: dar rum no santo. Neste estudo, reconheço este momento como a performance do rum, que só pode ser executada pelos filho-de-santo feitos. No caso dos abiãs, posteriormente tratarei da performance do bolar, equiparando-as como maneiras distintas de vivência da liminaridade na performance ritual.

${ }^{79}$ Barco de iaô: expressão usada para identificar o grupo de pessoas que vivenciam juntos o ritual iniciático. Os abiãs que realizam a feitura juntos, ou seja, que compõem um barco estão posicionados numa hierarquia interna que segue a simbologia dos orixás para os quais eles são iniciados. Esta ordem interna do barco deverá ser eternamente respeitada em inúmeras ocasiões, incluindo a dança no xirê. Para cada posição ocupada no barco há uma nomenclatura específica, que na modalidade jeje-nagô do culto é a seguinte: dofono, dofonitinho, fomo, fomutinho, gamo, gamutinho, vimo, vimutinho, gremo, gremuitinho etc. A quantidade de neófitos no barco é variável. 
abiãs.

Nas casas com muitos adeptos, esta roda de santo pode ser duplicada. Neste caso, a roda interior e, portanto, mais próxima do ariaxé (ou ixé), é sempre composta pelos mais velhos do culto, visto que "o grau de proximidade em relação ao ixé desenha no espaço o estatuto hierárquico superior dos ebomis" (Opipari, 2009, p. 126) ${ }^{80}$. Pela observação das insígnias do vestuário ritual - para os íntimos dos códigos do grupo - também é possível identificar a escala hierárquica, pois "a hierarquia encontra-se inscrita no vestuário e sobreposta aos corpos dos iniciados" (Duccini, 2016, p. 210).

Importante observar também, que os ogãs jamais dançam em rodas de candomblé. Eles ficam posicionados próximos aos instrumentos de música sacra, mesmo que não estejam na incumbência de executá-los. Quando um abiã é suspenso como ogã, passa a não dançar mais na roda e poder ficar de pé junto dos outros já confirmados. Conforme explica Braga (2009, p. 65), em alguns terreiros ainda encontramos as chamadas cadeiras de oga ${ }^{81}$, da mesma maneira, outras cadeiras enfeitadas com tiras de pano são dispostas no salão, para os convidados ilustres do terreiro. Esta estrutura lembra bastante a arquitetura dos grandes teatros com seus camarotes e balcões nobres. Então, quanto maior a antiguidade e o prestígio do religioso, mais valorizada a sua posição no barracão em dia de festa. Em boa parte dos casos, o sacerdote permanece sentado em seu "trono" observando a tudo, e recebendo constantemente as reverências dos fiéis e dos próprios orixás manifestados no corpo dos iniciados. No desenrolar das performances rituais, "a troca de saudações rituais ou troca de benção assinala a posição de cada indivíduo" na cena (Opipari, 2009, p. 127).

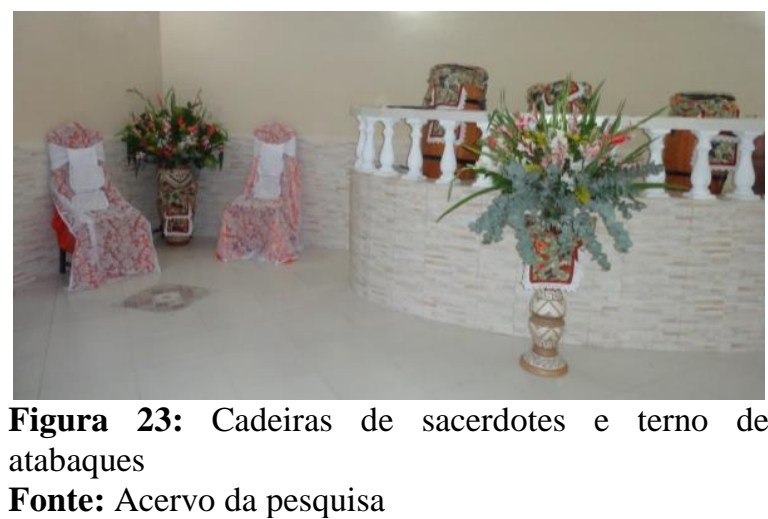

Fonte: Acervo da pesquisa

\footnotetext{
${ }^{80}$ Mantive a grafia da autora.

${ }^{81}$ A cadeira de ogã representa um sinal de prestígio na hierarquia religiosa do candomblé. Sempre está posicionada num local de destaque do barracão, de preferência próxima aos polos de maior gradiente de sacralidade, ou seja, ao lado da cadeira da liderança ou no ariaxé. No dia da cerimônia pública da confirmação de ogã , é sentado nela que o fiel recebe as reverências de toda a comunidade litúrgica. Para maiores aprofundamentos ver: Braga (2009).
} 


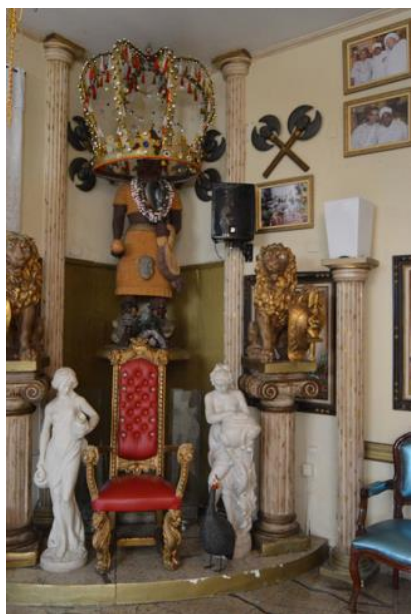

Figura 24: Cadeira ou trono do sacerdote

Fonte: Google Imagens $®$
A sequência musical do xirê poderá variar em cada terreiro. No geral, são tocadas umas três cantigas ou mais para cada divindade que compõe o panteão cultuado pela comunidade litúrgica. Esses cânticos seguem uma ordem hierárquica estabelecida pela cosmologia do culto. Há uma variedade de ritmos que orienta toda a dança ritual, pois "no candomblé tudo é ritmo, pois a vida é ritmo; a respiração é ritmo, e a própria criação nasceu do sopro de Olorum $^{82}$. Cada um dos ritmos conhecidos no candomblé está associado a um orixá, às vezes a mais de um" (Lépine, 2009, p. 321). Dentre alguns ritmos que presenciei sendo tocados nos terreiros que observei neste estudo, destaco alguns, como o alujá ${ }^{83} \mathrm{e}$ batá (para Xangô), o agere (para Oxosse), o opanije (para Omolu) e o ígbin (para Oxalá $)^{84}$, dentre tantos outros.

As cantigas rituais são todas entoadas num esquema de coro, no qual os ogãs cantam um refrão e os demais respondem em uníssono. Esse sistema segue do início ao final da festa, como num diálogo comunal. Ao participar do xirê os fiéis conjugam inúmeras habilidades como a audição, a coordenação motora e a memória. Além do que, esta experiência compartilhada através de uma intensa dinâmica expressiva, acarreta um profundo sentimento de coletividade e de descoberta da plasticidade do próprio corpo. Isto nos faz lembrar as reflexões de Evans-Pritchard a respeito da dança da cerveja entre os Azande na África Central:

A dança traz à baila todo o sistema muscular do bailarino, exige as atividades da visão e da audição e produz nele um sentimento de vaidade. Todas estas experiências são intensificadas pelo fato de serem expressas coletivamente. [...] o dançarino é compelido a coordenar suas ações com aquelas dos outros dançarinos e esta coordenação constrangedora é agradável. Há também a tendência ao aumento da boa vontade e para a produção de um sentimento de concórdia. (Evans-Pritchard, 2014, p. 35)

\footnotetext{
82 Olorum: ou Olodumaré são as expressões utilizadas pelos candomblecistas para designar Deus. Estas como outras terminologias são oriundas da filosofia iorubá, que é base adotada nos candomblés de modalidade jeje-nagô.

83 Para maiores aprofundamentos a respeito dos ritmos e das cantigas características de cada divindade do panteão Jeje-Nagô, consultar: Barros (2005 p. 65-71); Oliveira (2009).

${ }^{84}$ Neste estudo não irei me deter nas particularidades dos orixás que compõem o panteão jejenagô, conforme já foi feito exaustivamente na literatura especializada. (Verger, 2002; Silva, 2005 b etc.)
} 
No seu estudo a respeito das performances das iabás $s^{85}$ no xirê, Denise Zenícola $(2003 ; 2007 ; 2014)$ percebe um esquema tripartido das coreografias. A primeira fase ela identifica como os ritos de entrada ou danças de entrada, que seguem um padrão de repetição monótona de movimentos simples, numa espécie de aquecimento que facilita o transe.

Numa segunda etapa, ocorrem as danças de transe de orixá, quando eles retornam paramentados com suas vestes e insígnias para o salão. É nesse momento que acontece o que identifico como a performance do rum, onde o cada adepto-orixá desenvolve uma dança solo demonstrando sua biografia mítica. E, por último, depois de algumas horas de festa, ocorrem as danças de saída, em que os movimentos são menos ampliados e funcionam como uma despedida dos espectadores. Esta etapa é composta de gestos bem marcados que simbolizam uma separação entre divindades e espectadores. O ritmo final do xirê parece ter a função de desaceleração, ou seja, uma forma de preparar o corpo para o retorno ao ritmo natural, à dinâmica do cotidiano.

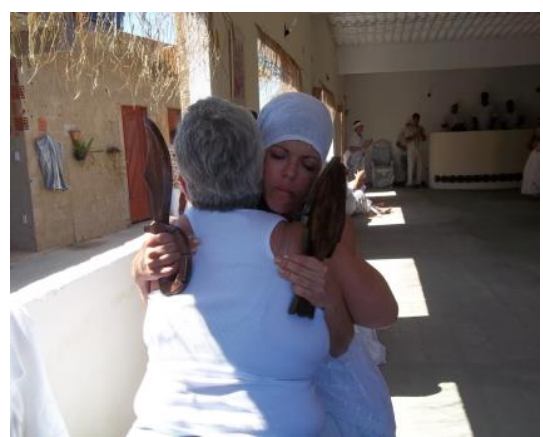

Figura 25: Interação adepto-orixá e espectadora

Fonte: Acervo da pesquisa
É comum os orixás abraçarem e beijarem os participantes do xirê. Uma cena curiosa de se notar é quando os orixás passam o suor do próprio rosto nas pessoas da audiência, como um sinal de transmissão de axé por contato. É comum também vermos as divindades presentearem o público com partes de suas insígnias. Inclusive durante um abraço muitos abiãs acabam por

bolar tamanha a absorção do "fluxo da performance" (cf. Schechner, 2011). Este fato opera no ritual com a mesma propriedade de uma espécie de mana (cf. Mauss, 2003; 2013).

Enfim, o xirê constitui-se polissêmico, podendo representar: exposição pública da eficácia dos rituais realizados na esfera privada; demonstração de habilidades desenvolvidas; reciprocidade (cf. Mauss, 2013) entre performers e espectadores; comemoração; agradecimento; contato com o sagrado manifestado

${ }^{85}$ Há um princípio de gênero que classifica e organiza todos os elementos e práticas no candomblé. No tocante à cosmologia temos uma subdivisão entre as divindades femininas (iabás) e as masculinas (oborós). 
(cf. Artaud, 2006); socialização e, por que não dizer, divertimento. Na sua polissemia característica, na dança ritual se sobressai a função sociológica de produção de coesão grupal e afirmação identitária, para além das suas funções psicológicas e fisiológicas, posto que "trata-se essencialmente de uma atividade coletiva, e não individual, e devemos explicá-la, portanto, em termos de função social, o que equivale a dizer que devemos determinar seu valor social" (EvansPritchard, 2014, p. 21).

São nos momentos em que os terreiros se abrem para o mundo social mais amplo através da festa, que “o barracão 'transforma-se' em sala. Sala é o espaço público de uma casa por excelência, em que todos convivem, e, muito importante, onde se exibe o que se tem de melhor porque é aí que as visitas são recebidas" (Souza, 2007, p. 138). Nessa acolhedora recepção do xirê, que identificamos a tamanha força que as performances ali realizadas exercem sobre a subjetividade dos participantes, como me relatou certa vez a abiã Vanise: "Então a todo o momento tinha xirê dentro do barracão. Quando cantava, aquilo mexia muito comigo. Eu já entrava na roda suando, né. Eu já ficava assim nervosa”.

Sendo assim, é por meio das festas dos orixás, que boa parte dos adeptos acaba tendo um primeiro contato com a religião. E, transportados espacial e psicologicamente (cf. Schechner, 2003; 2012a) pelas performances das quais participaram como espectadores, chegam à decisão íntima de que foram transformados temporariamente (cf. Schechner, 2003; 2012a) no seu interior. É nesse momento "mágico" - em que ritual e teatro se confundem - que muitos deles seguem encantados e vacilantes rumo aos primeiros passos do desconhecido abianato. 


\title{
"A gente é a chave de entrada para a religião": Abianato e performance ritual nos candomblés
}

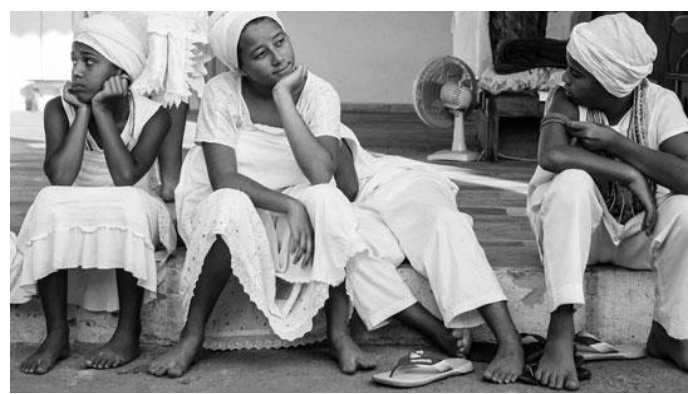

Figura 26: Abiãs e iâ̂ à direita

Fonte: Google Imagens ${ }^{\circledR}$

\section{1}

\section{"O abiã é o começo, o pé da história" - O corpo e suas metáforas nos candomblés}

\begin{abstract}
Eu acho que o abiã é o começo. É o pé da história. No caso, todo mundo que tá lá em cima, os maiores, os cabeções, foram abiãs. Todo mundo tem que passá, tem que começá. Então eu acho que é o começo de tudo, dos ogãs, das equedes [...] Às vezes as pessoas podem conseguir se vê no passado vendo um abiã dentro do barracão. No caso, é o começo de todo mundo. [...] Ser abiã pra mim é o começo de uma trajetória. (abiã Clayton)
\end{abstract}

No percurso desses últimos anos pesquisando as trajetórias dos abiãs nos terreiros de candomblé, ouvi incontáveis histórias de vida e diversificadas expressões metafóricas para explicarem as experiências de abianato. Contudo, numa tarde de longa conversa, escutei do abiã Clayton aquela que mais me inspiraria até então: "Eu acho que o abiã é o começo. É o pé da história". Tamanho foi o impacto desta simbologia no meu imaginário ao longo desse tempo, que coloquei-a como título deste estudo, acreditando que poderia sintetizar bem a relevância do abianato no processo iniciático do fiel, tanto quanto demonstrar a centralidade das experiências corporais que esta fase envolve. Entendo aqui a experiência como "aquilo que nos passa, ou nos toca, ou nos acontece, e ao nos passar nos forma, e nos transforma" (Larrosa, 2004, p. 163). Por este prisma, neste estudo, o abianato é encarado como uma experiência, e o abiã como um "sujeito da experiência":

[...] o sujeito da experiência é uma sujeito ex-posto. Do ponto de vista da 
experiência, o importante não é nem a posição (nossa maneira de pôr-nos), nem a o-posição (nossa maneira de opor-nos), nem a im-posição (nossa maneira de impor-nos), nem a pro-posição (nossa maneira de propor-nos), mas a exposição, nossa maneira de ex-por-nos, com tudo o que isso tem de vulnerabilidade e de risco. Por isso é incapaz de experiência aqueles que se põe, ou se opõe, ou se impõe, ou se propõe, mas não se ex-põe. (Larrosa, 2004, p.161)

A partir desta perspectiva, durante a incursão etnográfica, estive bastante atendo às formas de experiência do abianato e das consequentes maneiras de retratá-lo nas performances discursivas dos fiéis. Atento a isso, observei que a maior parte das metáforas usadas pelos abiãs que entrevistei, giravam sempre em torno da ideia de fase inicial ou transitória. De fato, melhor do que ninguém, os abiãs não poderiam deixar de externar esta certeza. Afinal, como este estudo pretende enfatizar também, realmente são eles, e não os iaôs, o início do processo iniciático do candomblé. E, por ser o início, é mais que óbvia a sua transitoriedade revelada nas figuras de linguagem que povoam os discursos dos sujeitos desta experiência. Portanto, a reivindicação que os abiãs fazem para si desta posição crucial no processo iniciático, algumas vezes é também enunciada por outros atores que acompanham o abianato de perto. Como certa vez me afirmou o jibona $\tilde{a}^{86}$ Ronaldo, ao falar sobre os 18 abiãs que ele criou no processo de feitura:

Só que o abiã, ele é o início de tudo! O iaô não é o início. Porque falam: $a h$, o iâo é o início de tudo. O início de tudo é o abiã. É ele que vai se encantá e depois... iaô você já passou! Você já é feito! [...] Ele que vai continuar. Se acabou o abiã, acabou! [...] O ciclo vai pará, né? O abiã é o que busca, o que vai continuá. O que movimenta. [...] Tem que ter o abiã. Porque é ele que vai fazer aquela energia, aquela coisa de se iniciar. (ebôme Ronaldo)

Mas não foi a percepção expressa com a ideia de fase passageira que mais me chamou atenção no discurso do abiã Clayton. Inclusive até esse ponto, nada havia de original na sua declaração. Por conseguinte, foi ao dizer que o abiã é o "pé da história" que ele despertou em minha mente uma reflexão bastante provocadora, que me impulsionou ainda mais até aqui. Era a primeira vez que eu ouvia uma definição para o abiãa, que destoasse dos campos semânticos até então acessados pelos discursos dos meus interlocutores. A seguir, apresento num

\footnotetext{
${ }^{86}$ Jibonã ou ajibonã (cf. Cacciatore, 1977, p. 159): categoria nativa para identificar a pessoa responsável pelos cuidados e ensinamentos do neófito ao longo da reclusão iniciática. A expressão do iorubá (ojùgbònà) significa: aquele que dá caminho ao nascimento. Trata-se de um cargo sacerdotal geralmente feminino. Usa-se também a expressão mãe-criadeira. No caso de Ronaldo, em seu terreiro não havia uma pessoa que possuísse efetivamente esse cargo. Portanto, pai Carlito conferia a realização da tarefa a alguns filhos-de-santo, de acordo com a confiança e a disponibilidade de tempo.
} 
quadro as expressões mais recorrentes, organizadas a partir de uma classificação baseada em três grupos semânticos que observei:

\begin{tabular}{|c|c|}
\hline Ideia Transmitida & Metáforas utilizadas \\
\hline $\begin{array}{l}\text { 1. Fase inicial ou } \\
\text { provisória }\end{array}$ & $\begin{array}{l}\text { início; iniciante; pré-iaô; namorado; começo; bebê; estudante; } \\
\text { primário; estagiário; cru; [fase do] "grosso"; [fase do] "todo". }\end{array}$ \\
\hline 2. Objetificação & $\begin{array}{l}\text { chave; página em branco; base da pirâmide; ponto de interrogação; } \\
\text { instrumento da "casa". }\end{array}$ \\
\hline 3. Subserviência & servo; mão de obra barata; instrumento da "casa". \\
\hline
\end{tabular}

Quadro 1: Síntese das metáforas utilizadas pelos abiãs como autorrepresentação

Fonte: Elaborado pelo autor

Clayton, na contramão de todos os discursos que presenciei, utilizou uma parte do corpo humano para explicar metaforicamente sua condição de abiã. Sem ter conhecimento mais profundo dos inúmeros rituais que são realizados nos pés dos neófitos no candomblé, ele acabou fazendo uso de um símbolo por demais eloquente na visão cosmológica desta religião. Embora talvez não tenha percebido tantas nuances no que me disse naquele momento, sua declaração me deixou perceber como realmente a experiência do abianato é mais que um período de mútua apresentação dos indivíduos.

Pelo fato de não ser iniciado, nem ter participado dos "bastidores" de algum rito de iniciação, a simbologia do pé poderia ter surgido de uma mistura dos valores externos ao candomblé, com a percepção implícita da centralidade e valorização do corpo na sua nova religião. Afinal, Clayton havia passado assiduamente 15 anos na igreja católica, e como ele mesmo percebia, estava modificando aos poucos a forma cristã de olhar o mundo, que aprenderá desde tenra idade. Ao longo do abianato, embora se mostrasse bastante realizado na escolha deste novo estilo de vida, com muita recorrência ele relembrava este esforço cotidiano de reconstrução do próprio eu:

Estou esquecendo aos poucos. Assim, esquecendo da rotina. Mas ainda assim, tenho... aprendi também muita coisa na igreja [...] Então, quinze anos não foi... acho que não foi tipo... saí e joguei tudo fora. Eu aprendi o que tinha que aprender, só que eu vi que não era... eu vi que não ia dar certo continuar [...] acho que esses dois anos que eu tenho no candomblé, eu acho que realmente eu me encontrei mais com o candomblé do que quinze anos dentro da igreja católica. (abiã Clayton)

Para além da espontaneidade de sua resposta, não pude deixar de ter certeza que se tratava de uma relação simbólica bastante relevante para o contexto 
ritual do candomblé, que neste caso, também estava sendo pensado como um corpo. Nota-se que em sua explicação, ele coloca em oposição o grupo de pessoas antigas no culto, representadas por outra parte do corpo: cabeções, ou seja, a forma ampliada da cabeça. Sua ilustração traz à tona uma polarização extremamente contundente no sistema simbólico da liturgia do candomblé. Embaixo, nos pés, os abiãs. No topo, nas cabeças, os já iniciados ou instituídos, como diria Bourdieu (1982) a respeito dos que vivenciam os ritos de passagem.

Nesta circunstância, caberia resgatar as reflexões de Le Breton (2012) a respeito do corpo humano e as representações e valores atribuídos assimetricamente a cada uma de suas partes na cultural ocidental, chamando atenção para o papel desprestigioso dos pés. Nas diversificadas atribuições valorativas aos órgãos e funções do corpo nas culturas, nota-se que "para nossas sociedades, por exemplo, os pés não tem valor: órgãos situados embaixo do corpo encarnam a escala mais baixa do valor" (Le Breton, 2012, p. 70). Sem estar tão consciente ou mesmo preocupado com este aspecto, Clayton com sua espontânea percepção, nos relembra que "um sistema de valores divide os diferentes órgãos e as diferentes funções do corpo humano, de acordo com as sociedades" (Le Breton, 2012, p. 71).

É certo que há grande ambiguidade na expressão começo, pois da mesma maneira com que pode conotar algo incipiente, ainda fraco, não desenvolvido, pode levar-nos a pensar como sendo algo de relevância ontológica, já que determina a existência do todo. Neste ponto, a metáfora estaria plenamente condizente com a própria cosmovisão das religiões de matrizes africanas, que acreditam-se inseridas num eterno ciclo de nascimento-morte-nascimento, no qual os ancestrais ocupam posição de elevado prestígio e adoração. Da mesma maneira então, a metáfora do pé atinge outro foco valioso das crenças de matrizes africanas: a ancestralidade. É exatamente o pé a parte do corpo relacionada aos ancestrais:

O corpo humano em si é microcosmo. Os pés apóiam-se no concreto, no barro de onde saiu para onde voltará, na terra que os antepassados pisaram e à qual retornaram. $\mathrm{O}$ pé direito corresponde à herança dos antepassados masculinos, e $\mathrm{o}$ pé esquerdo, à herança feminina. As mãos, direita e esquerda, atuam sobre o mundo e transformam as coisas. A cabeça, que reproduz as quatro dimensões do espaço, contém, na interseção dos pontos cardeais, o centro da individualidade, ori-inu, manifestação do duplo sagrado, que provém de substância divina, da qual os próprios deuses são atributos. A pessoa é, portanto, um feixe de linhas convergentes e divergentes, estrutura que tem papel específico no equilíbrio do 
mundo. (Augras, 2008, p. 61)

Aliás, um dos primeiros aprendizados de um abiã no terreiro, é justamente andar de pés descalços. Logo que se chega à casa de axé, deve-se deixar os pés desnudos e lavar o corpo num banho lustral chamado $a b \hat{o}^{87}$. Só então, o devoto estará apto a "um contato direto do corpo com a terra, com o mundo dos ancestrais, pois o corpo é o meio e a forma de expressão para a comunicação sagrada". "Os pés tocam e se comunicam com a ancestralidade" (Sabino \& Lody, 2011, p.76).

É no contato dos pés com o chão que se estabelece a tão desejada conexão com os ancestrais, representados pelas raízes das árvores. Neste esquema simbólico, o corpo seria a própria árvore e os pés as raízes, que sobem pela coluna vertebral e alcançam a cabeça representante da dimensão espiritual,

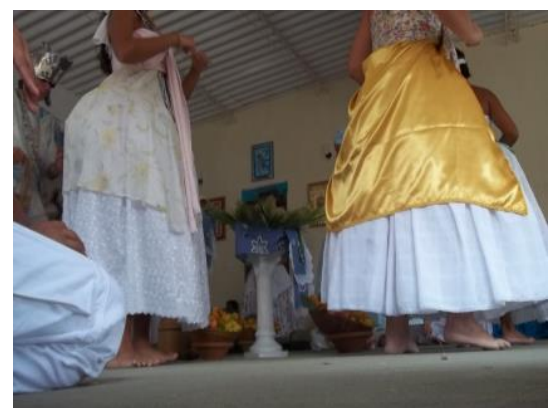

Figura 27: Contato ritual com o chão Fonte: Acervo da pesquisa ou seja, os próprios orixás. Daí, a feitura da cabeça, ou seja, o reforço da dimensão espiritual da existência. Enquanto que os braços estendidos representam os galhos que possibilitam a socialização do indivíduo no mundo. O simbolismo é claro: o equilíbrio do ser humano dependerá sempre da harmonização dessas três dimensões: a ancestralidade, a vida no mundo material e a dimensão espiritual do ser.

Com isso, "metaforicamente, o pés são as partes do corpo que nos fazem percorrer nossos caminhos. O homem pisa no destino com a herança dos ancestrais" (Jagun, 2015, p. 29). A percepção da relevância desta relação dos pés com o chão pode ser inúmeras vezes percebida nas descrições dos fiéis a respeito de suas experiências sensoriais, principalmente quando os abiãs no treino do transe, "sentem a aproximação do orixá como uma força que vem do chão e que

\footnotetext{
${ }^{87}$ Abô ou água de abô: expressões usadas no candomblé para identificar o banho ritual produzido com a maceração de diversas ervas, seguindo um cerimonial específico. Há diferentes tipos de $a b \hat{o}$, para usos específicos. Neste caso, me refiro ao abô coletivo. Apenas os devotos iniciados para Oxalá não poderão utilizá-lo. A particularidade deste banho ritual é ser armazenado num recipiente de barro que deve estar exposto à natureza ou guardado no peji para fermentar. Geralmente, fica aos pés de uma árvore sagrada do terreiro. É uma praxe ritual, todos os religiosos tomarem este banho sempre que chegam ao templo litúrgico. Usa-se também a ingestão. Só após este ritual purificador e a colocação das vestes adequadas que o fiel realizará os cumprimentos às divindades do terreiro, e consequentemente aos seus pares. Para maiores informações ver: Lody (2003).
} 
desorganiza a relação habitual entre corpo e espaço" (Rabelo, 2014, p. 259). Em muitos momentos fica claro o desenvolvimento de uma sensibilidade ligada ao chão no discurso dos abiãs:

A primeira vez que eu pisei lá eu comecei já a me arrepiar. Eu gostei! Gostei muito. (abiã Caterine)

O santo não vem da essência de riqueza não. O santo vem do chão! É energia, é água, é terra, é ar. (abiã Odete)

O chão da casa dele não era de granito, nem de azulejo, era de terra e tinha aquele assentamento no meio certinho. Tinha aquela parte dos ogãs na frente, tudo bonito. E era de terra, então, quando você pisava, você sentia o axé da casa. (abiã Patrícia)

A energia, você botava o pé na areia, que energia gostosa! Era uma coisa muito diferente, muito surreal! Eu senti uma vibração gigante! Gente, eu nunca vi isso. Eu me arrepiava da cabeça aos pés. (abiã Afonsinho)

A relevância dos pés nos ritos do candomblé pode ser percebida também quando verificamos os nomes destas formas de religiosidade nas descrições de suas origens africanas (cf. Bastide, 2001; Lima, 2010; Santos, 2002). Nos cultos trazidos de algumas regiões da África Ocidental para o Brasil, tínhamos a seguinte diferenciação de modalidades religiosas: lessé orixá e lessé egúngún (cf. Lima, 2010; Santos, 2002). As expressões são oriundas do iorubá e compreendidas como "aos pés do orixá" e "aos pés dos ancestrais". O termo lessé é traduzido como "aos pés", devido ao vocábulo essé significar pernas ou pés, em iorubá (cf. Lima, 2010, p. 80; Leite, 2008, p. 29).

Como já foi esclarecido em nota anterior, a modalidade de culto lessé orixá tornou-se a mais difundida no Brasil, embora tenha recebido denominações específicas em cada região, como por exemplo candomblé. Afirmam alguns autores (Leite, 2008; Santos, 2002) que em culturas tradicionais iorubá essé é considerada uma parte vital da personalidade humana, no sentido físico e espiritual. Esta parte do corpo constitui-se como o símbolo do poder e da atividade, habilitando o homem para lutar na vida e realizar o que foi designado para ele. Há um trecho de um poema mítico iorubá que diz: Enikan kì í gbìmòran/ k'ó yo t'esèe 'lè, ou seja, "ninguém realiza nada se não tiver pernas" (Abimbola, 1981, p. 18).

Como explica Leite (2008), em algumas culturas africanas, os dedos 
maiores dos pés são considerados divindades com reverências rituais próprias. No candomblé, há diversos procedimentos rituais realizados nos pés, o que confirma o grande valor simbólico desta parte do corpo. De fato, a relevância simbólica dos pés é mais restrita aos procedimentos litúrgicos privados nos candomblés. De qualquer maneira, para cada parte do corpo há uma forma de exaltação e ritualização própria, que segue um complexo esquema de símbolos:

A frente do corpo, especialmente a fronte, se encontra associada ao futuro; a parte posterior, sobretudo a nuca, ao passado. Os membros inferiores estão associados aos ancestrais, sendo que nos rituais de iniciação esta relação é reforçada e atualizada. O lado direito do corpo é considerado masculino; o esquerdo, feminino, dizendo respeito à ancestralidade masculina e feminina, respectivamente. Observamos que em vários rituais a sola dos pés deve permanecer em contato com o chão, visando ao estabelecimento da ligação com importantes poderes que emanam do elemento terra, também chamado de aiê. Já as mãos são consideradas como entrada e saída de forças provenientes dos orixás. (Lépine, 2000, p. 114)

Todavia, a parte do corpo mais valorizada e comentada nas religiões afrobrasileiras é a cabeça. Beniste (2015) comenta que o "orí é todo o àse [axé] que uma pessoa tem, e sua sede é na cabeça. É ela que, geralmente vem primeiro ao mundo e abre caminho para trazer o resto do corpo. Ela é a sede da consciência e dos principais sentidos físicos” (Beniste, 2015, p. 129). O próprio rito de iniciação no candomblé é nomeado por expressões nas quais este termo é frequentemente utilizado, como: feitura da cabeça, fazer cabeça, raspar cabeça etc. Isto está diretamente atrelado a um sistema simbólico no qual a cabeça ocupa uma posição superior no esquema corporal. Interessante lembrar que a metáfora que o abiã Clayton usou para se referir aos seus superiores hierárquicos foi justamente cabeções. Além de ser a parte mais valorizada da estrutura corpórea, ele a colocou numa dimensão ampliada, ressaltando ainda mais sua condição dominante sobre o resto do corpo.

Os adeptos que participaram desta pesquisa, que eram praticantes da modalidade religiosa jeje-nagô, partilham uma noção de corpo inscrita numa representação simbólica praticamente unânime. A primeira noção a ser exposta é a de que não há uma dualidade que separa radicalmente corpo e alma. Como afirma Lépine (2000), no candomblé "a alma tem qualquer coisa de material e o corpo alguma coisa de espiritual” (Idem, 2000, p. 110). Com poucas variações, estes devotos acreditam que são três os elementos constitutivos do homem: essé, as pernas, por extensão, o organismo fisiológico num todo. É também chamado de 
ará; emi, como a própria respiração, que de acordo com o mito cosmogônico representa o hálito que Olorum soprou nas narinas para dar vida ao corpo humana; e orí, enfim, a cabeça, onde está encerrada no seu interior a parte imaterial e eterna do ser, o ori inú. Como salienta Ziegler (1977, p. 94), o "emi e o ori uma vez criados, gozam de vida permanente, que nada poderá jamais alterar”.

Nos mitos iorubás ${ }^{88}$ que tratam da origem do homem, há um princípio do double, que assim como divide a existência em uma dimensão material (aiê) e outra imaterial (orun $)^{89}$, também explica a existência de um duplo do orí humano no orun. Como explica Augras (2008), "tudo que existe no mundo concreto, existe também no além. O mundo concreto é a manifestação física do outro mundo" (Augras, 2008, p. 56).

Neste esquema mítico, cada ser humano teria seu ori moldado por um tipo específico de argila mítica, que está relacionada a um dos orixás. Então, o orí que o homem carrega no aiê é o double de seu orí primordial chamado ipori, que está no orun (cf. Augras, 2008; Santos, 2002; Ziegler, 1977, p.105). Nos ritos de iniciação, os neófitos estariam realizando um movimento simbólico de reconexão coma esta matéria-prima primordial pessoal, no caso, representada pelo próprio orixá que está intrinsecamente ligado a ela:

Todos os ritos, desde a fundação do templo até a iniciação individual, todas as celebrações objetivam manter e ampliar a comunicação entre este mundo e o outro, assegurar a passagem das mensagens de um para o outro, aumentar as trocas, enfim, instaurar e desenvolver o numinoso. Isso se faz pela condensação e distribuição de energia, da força sagrada (axé) presente em todos os seres. (Augras, 2008, p. 57)

Uma vez explicitada a centralidade e simbologia do corpo na concepção religiosa do candomblé, torna-se mais perceptível o quão significativa foi a metáfora utilizada por Clayton para definir-se enquanto abiã. Entretanto, o mais

\footnotetext{
${ }^{88}$ Há uma profícua produção mitológica a respeito da origem do mundo e do homem, que não será aprofundada neste estudo. Apresento brevemente apenas as noções fundamentais para se compreender a dinâmica da existência segundo a visão teológica do culto aos orixás. Destaco que, os conceitos aqui apresentados foram selecionados por estarem de acordo com as modalidades de culto dos grupos que fizeram parte da pesquisa. Portanto, há outras interpretações no universo amplo e diversificado do candomblé.

${ }^{89}$ Esta duplicidade de dimensões da existência não deve ser confundida com o esquema céu e terra cristão. Na visão iorubá, esta noção é muito mais complexa, já que implica a existência de nove mundos. O que importa para este estudo é compreender o orun como uma dimensão imaterial ou sobrenatural, com a qual os humanos estão em constante interação no aiê, a dimensão física da existência. Além do que, importante destacar que o axé é o princípio que circula por todas estas dimensões. Para maiores aprofundamentos ver: Augras (2008); Beniste (2015); Santos (2002).
} 
curioso é o fato deste abiã ainda não estar inteirado a respeito de tudo disso, no momento em que lançou mão da referida metáfora. Portanto, esta noção corporal no candomblé é de extrema relevância para pensar todo o processo de aprendizado gestual no qual o abiã é inserido paulatinamente. É num corpo informado por todas estas condições físicas, psicológicas e simbólicas, que o abiã desenvolverá sua performance de transe de orixá a cada passo na complexa hierarquia iniciática. Sendo assim, desde o ingresso na experiência do abianato ocorre a descoberta do corpo como o instrumento primordial para atingir o encontro com o sagrado, corroborando com a assertiva de Mauss (2012):

Eu acredito que no fundo de todos os nossos estados místicos, existam técnicas do corpo que nós ainda não estudamos, mas que foram perfeitamente estudadas pela China e pela Índia, desde épocas muito antigas. Esse estudo sócio-psicobiológico da mística ainda deve ser feito. Eu penso que, necessariamente, existam meios biológicos para entrar em "comunicação com Deus". (Mauss, 2012, p. 275)

Como observou Le Breton (2012, p. 7), “antes de qualquer coisa, a existência é corporal". Portanto, no bojo das múltiplas práticas ritualísticas e sociais vivenciadas pelo religioso no candomblé, também podemos confirmar o papel desempenhado pelo corpo como "o âmago da relação do homem com o mundo" (Idem, 2012, p. 7), nas suas diversificadas esferas. O corpo no candomblé é ao mesmo tempo "o meio e a forma de expressão para a comunicação sagrada" do fiel (Sabino \& Lody, 2001, p. 75). Para os praticantes desta religião, o corpo é o próprio sagrado. Ao contrário do que muitas vezes se percebe em outras formas de religiosidade, nas quais o corpo pode representar uma espécie de ameaça à elevação espiritual, o corpo do filho-de-santo é a principal trilha capaz de levá-lo ao ápice de sua busca, de seu maior encontro: a dimensão sagrada da própria existência.

O abiã logo cedo percebe que ao corpo não são atribuídos valores de pecado ou promiscuidade mundana. A velha correlação entre o corpo e uma dimensão profana da vida, não encontra espaço na cosmovisão afro-brasileira. Assim, pude ouvir diversas vezes dentro dos terreiros que visitei algo bem semelhante ao que a abiã Odete me disse um dia: "O corpo da gente é o templo do orixá! Onde ele vai passar!" Ou poderíamos pensá-lo como "uma metáfora da divindade”, como explica Muniz Sodré (1988, p. 128). É a noção fundante de que o corpo não está à parte do sagrado. Através do corpo ritualmente preparado, o sagrado emerge e atua. O sagrado está no corpo, pois ele comporta a parte 
imaterial e eterna do ser, conforme a cosmologia iorubá seguida nos terreiros que observei.

Uma das primeiras lições oferecidas aos indivíduos que aderem ao culto dos orixás é a de que seu corpo pode e deveria ser despertado, explorado em toda a sua capacidade $e x$-pressiva. Ou seja, libertá-lo de todas as amarras e pressões que possam impedir a sua fruição plena. Falamos aqui da "alforria" de um corpo que no desenrolar do individualismo ocidental, aprisionou o homem sobre si mesmo. Conforme pontua Le Breton (2012) ao comparar as diferentes formas de experiências culturais do corpo, ora ele pode ser apreendido como uma fronteira entre os indivíduos, ora como elemento integrador. Em sua opinião, as ditas sociedades "tradicionais", que permanecem comunitárias, elevam o corpo ao seu status de meio integrador dos grupamentos humanos. Ao passo que, nas sociedades modernas regidas pelo individualismo, ele funcionaria como uma barreira, que preserva a soberania da pessoa:

O isolamento do corpo nas sociedades ocidentais, (eco longínquo das primeiras dissecações e do desenvolvimento da filosofia mecanicista) comprova a existência de uma trama social na qual o homem é separado do cosmo, separado dos outros, separado de si mesmo. (Le Breton, 2012, p. 31)

Todavia, na cultura elaborada na realidade dos terreiros de candomblé, a relação com o próprio corpo e o corpo dos outros, pretende-se um tanto subversiva desta ordem de coisas do mundo moderno. Os candomblecistas percebem o corpo do iniciado como um microcosmo, pois "nele estão contidos todos os elementos e forças da natureza, que distribuídos harmoniosamente, explicam a sua mitologia" (Zenícola, 2003, p. 100). Por este prisma, cada parte constituinte do corpo está intrinsecamente relacionada com um princípio cósmico, que sempre poderá ser ativado através dos rituais. Embora sejam atribuídos significados particulares para cada uma de suas partes, este corpo é sempre encarado como uma unidade, um sistema.

Este corpo sacralizado é a própria natureza, no sentido mais ecológico do termo. E, para o seu equilíbrio, passa a ser fundamental estar integrado ao macrocosmo constituído por toda a existência que o circunda, ou seja, os outros humanos e o meio ambiente. Por isso, a cosmovisão proposta por estas práticas litúrgicas preveem uma relação com o sagrado que não é transcendente, como na filosofia cristã difundida pelo dito ocidente. Os rituais - que na maior parte do 
tempo utilizam o movimento do corpo e a palavra pronunciada - visam um relacionamento com a divindade num "movimento de fusão com o cosmos (êxtase ou transe), que encontra na força um ponto de interseção entre a comunidade e o cosmos" (Sodré, 1988, p. 98-99).

No entanto, mesmo o abiã estando inserido em todo esse conjunto de práticas corporais e de simbologias, frequentemente é lançado sobre ele um olhar que não encara esta participação como uma etapa efetiva de sua processual iniciação religiosa. Os discursos sobre o abianato deixam transparecer na maior parte das vezes, a ideia de que a iniciação está unicamente atrelada ao rito de feitura. Assim, na perspectiva de que o candomblé é uma religião de cunho iniciático, o momento efetivo do rito de iniciação acaba sendo sempre demarcado como o início exato da "carreira" iniciática dos fiéis. O que acaba por descreditar a importância ritual de um período - que pode ser de dias, meses ou anos - de intensa convivência do indivíduo no status de abiã dentro do terreiro. Para sairmos dessa contradição, poderíamos lembrar as considerações de Schechner a respeito da grande validade que a convivência e a observação apresentam para a "restauração do comportamento" que irá configurar as performances dos indivíduos:

Comportamento de performance é aprendido e praticado - ou duplamente, comportamento treinado, comportado. Comportamento restaurado. Então, ensaio prévio, aprendizado por osmose desde a infância, revelado durante a performance pelos mestres, guias, gurus ou, generalizando, pelas regras que governam de fora, como em esporte ou teatro improvisado (apud Silva, 2007, p. 68).

Portanto, este abianato é muitas vezes resumido nos verbetes socioantropológicos, ou no discurso simplificador de alguns adeptos, a uma fase de mera convivência sociológica, na qual se esquece da ideia basilar do candomblé, de que tudo está impregnado de um axé, que pode ser transmitido pela própria convivência. Na sua contribuição ao salientar a acepção ritual da "convivência", ou "participação" como Goldman (2012) prefere, podemos aferir que na lógica do terreiro - considerado um organismo vivo - seria contraditória a afirmação de que durante o abianato o indivíduo já não estaria sob a égide de um processo iniciático no candomblé.

Ao longo de seu artigo, Goldman (2012, p. 278) relembra passagens etnográficas, suas e de outros antropólogos, que exemplificam esta concepção de "participação ritual” na vida cotidiana do terreiro. Logo de início, cita o 
humorado episódio etnográfico de uma cadela que havia passado algum tempo em reclusão com dois diferentes barcos de iâ̂ e, portanto, era considerada no terreiro "quase uma iniciada - mesmo que não tivesse sido 'raspada"' (Idem, 2012, p. 278). Coincidentemente, uma situação bastante similar ocorria no terreiro de pai Carlito. Lá também havia uma cachorra chamada Pretinha, que além de conviver livremente nas áreas do terreiro, vivia comendo escondido as oferendas depositadas aos pés dos assentamentos das divindades da área externa. Por isso, quando os iaôs recém iniciados cumpriam a saudação ritual do dobale $e^{90}$ aos mais antigos do templo, sempre aparecia um fiel bem humorado para lembrar da presença de Pretinha como uma das ebômes mais antigas do barracão.

Entretanto, Goldman complemente sua exposição com outro exemplo bastante contundente. Certa ocasião, o antropólogo presencia um "batizado", com direito a padrinhos, de uma árvore no quintal de um terreiro. No seu instinto antropológico, o pesquisador indaga se aquela seria uma árvore especialmente consagrada a alguma divindade. Para sua surpresa, responderam-lhe que não: "todas as árvores que são plantadas na área de um terreiro de candomblé vão se tornando especiais à medida que absorvem a força das oferendas e das pessoas que por aqui passam" (Goldman, 2012, p. 278).

A partir destas proposições de Goldman (2012), o que poderíamos pensar da prolongada convivência de diversos abiãs no cotidiano dos terreiros antes da feitura? Seria o abianato apenas um momento de mútuas apresentações e avaliações, ou poderíamos tomá-lo também como um estágio de treinamento, de introjeção de "técnicas corporais", ou de "restauração de comportamento", conforme propôs Schechner (1988, 2003, 2012a; 2012b).

Este estudo propõe um novo olhar para o abianato justamente com o foco nesta problemática. Baseado no prisma de Schechner ao reforçar o continuum entre ritual e teatro, esta etnografia busca compreender a fase do abianato de maneira profundamente intrincada com a performance de transe de orixá que o abiã vivenciará após a iniciação. Porém, ainda no período do abianato, o material etnográfico nos mostra que o abiã também vivencia um tipo de performance

\footnotetext{
${ }^{90}$ Dobalé: saudação ritual realizada por aqueles iniciados para divindades femininas. Mesmo que o neófito seja um homem. Nesta modalidade, deita-se ao comprido no chão, apoiando-se nos quadris e nos antebraços, uma vez para o lado direito, outra apara o esquerdo. O importante é não encostar a região ventral no chão. No caso dos iniciados para divindades masculinas, diz-se icá. Nesta modalidade, atira-se ao solo com a barriga voltada para o chão.
} 
preliminar através do fenômeno de bolar ou "passar mal". Por isso, veremos que a performance do bolar configura uma fase de treino e aprendizado para a performance do rum. E, embora em níveis diferentes, ambas as experiências performáticas apresentam as mesmas condições propostas por Schechner (1988, 2003, 2012a; 2012b), como liminaridade, transportation e transformation.

\section{2}

\section{To be or not to be - Entendendo o papel de abiã}

Abiyan ajê (abiã riqueza)

Abiyan owô (abiã dinheiro)

Abiyan omó (abiã filho)

Abyian aji dide (abiã acordado levantado)

O termo abiã é originário do iorubá abíyán ( $a$ - aquele, bí - que nasce, iyán - com dúvidas) e tem como possível versão, "aquele que vai nascer" (cf. Beniste, 2015, p. 242-243; Lima, 2011, p. 92). Este nascer está estritamente relacionado ao rito iniciático que é composto de um simbolismo de morte e renascimento. No candomblé, esta categoria é usada para classificar todas as pessoas que efetivamente ingressam para uma determinada comunidade litúrgica, porém sem passarem pelo ritual de iniciação. Portanto, de antemão, definimos que visitantes e clientes dos serviços mágico-religiosos prestados pelo terreiro, não se enquadram nesta categoria.

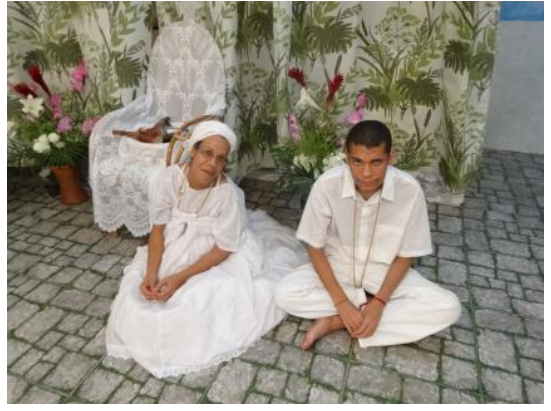

Figura 28: Abiãs no xirê Fonte: Acervo da pesquisa

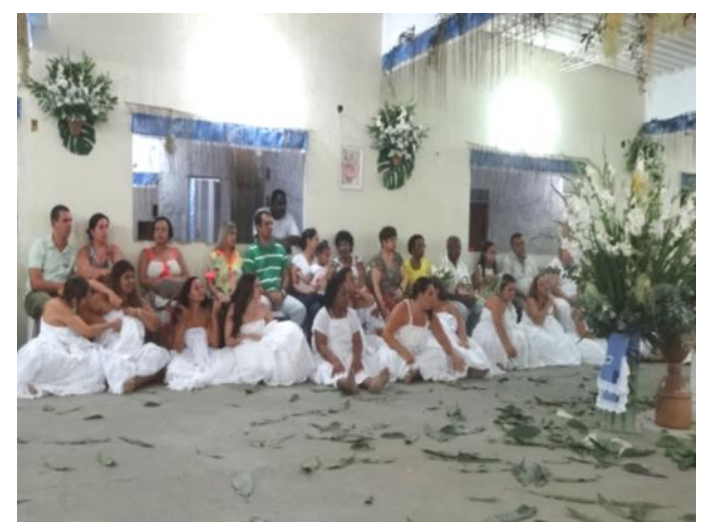

Figura 29: Abiãs no chão durante o xirê Fonte: Acervo da pesquisa

Por seu caráter instável e seus vínculos superficiais dentro da religião, há os que afirmam que, de fato, um "abiã não tem casa" (Cossard, 2006, p. 104). Todo abiã tem igualmente latente e iminente as possibilidades de adesão completa 
ou de deserção repentina da religião e do templo religioso. Isto pôde ser percebido durante este estudo, nas biografias de alguns abiãs em trânsito, seja pela troca de templos ou pelo afastamento periódico da religião. A percepção desta fragilidade do papel de abiã nos terreiros é revelada em alguns discursos:

O abiã não tem responsabilidade. Tem a responsabilidade de chegar no barracão e fazer seus deveres. Mas não de... não chega ao profundo [...] Abiã é você praticamente tentar buscar...é como se fosse procurar uma essência. Descobrir o porquê estou ali. (abiã Odete)

Onde você tem mais oportunidade de aprender, de vivenciar, porque você ainda não tem um vínculo. [...] é você aprender sem compromisso. É o momento que você tem pra definir se é aquilo dali ou não [...] Enquanto abiã você tem opção, entendeu? (abiã Priscila)

O abiã tá iniciando, não sabe nem se é rodante ${ }^{91}$, ogã ou equede. Não sabe nem que santo que é. Você é um abiã, é um ponto de interrogação. (abiã Patrícia)

Por conseguinte, muitos religiosos definem o abianato apenas como um momento de conhecimento mútuo do abiã e de uma comunidade litúrgica específica. Isto configuraria, num olhar superficial sobre a questão, apenas uma espécie de fase de apresentação, para verificar se ambos têm compatibilidades ideais para estreitarem laços sociais e rituais.

Num artigo publicado pelo cientista social e babaebé ${ }^{92}$ Adaílton Moreira (2007), há uma interessante narrativa a respeito da trajetória de um fiel, desde o seu ingresso como abiã até o ritual iniciático da feitura. Ao longo do texto, o autor vai pontuando o quanto o abianato apresenta um caráter introdutório do fiel ao ethos do terreiro e seus princípios fundamentais, como ancestralidade e respeito à natureza. Num dado momento de sua reflexão, Adaílton parece fazer uma ressalva, que corrobora com o que tratamos neste estudo. Primeiramente, ele afirma que só após a introdução ao grupo religioso e suas respectivas convicções, o abiã estaria pronto para o trabalho da iniciação. Mas logo em seguida, o autor parece ajustar sua colocação. Este ajuste é para lembrar ao leitor, que seria um verdadeiro equívoco supor que todo o período do abianato não comportaria

\footnotetext{
${ }^{91}$ Rodante: a pessoa que desenvolve a capacidade de entrar em transe de orixá. Isto será abordado mais adiante. A categoria oposta seria não rodante.

92 Babaebé: título honorífico traduzido como "pai da comunidade". Há também um correlato feminino, iaebé, portanto, "mãe da comunidade". Trata-se de um cargo sacerdotal de alta relevância e confiança, pois assessora o líder espiritual na condução da comunidade litúrgica (ebé). Como explica Adaílton, é "a pessoa que organiza a sociedade religiosa, seja para aos rituais, seja para necessidades sociopolíticas da comunidade religiosa”. (Moreira, 2007, p. 105)
} 
nenhum sentido ritual, ou seja, que constituísse apenas uma participação sociológica no grupo religioso:

Para as pessoas poderem se tornar um iaô [...] elas têm antes que ser um abiã, um não iniciado, que é o processo de relação social com a comunidade religiosa da qual elas procuram fazer parte. [...] É uma gama de elementos que passamos para o abiã a fim de criar uma relação de identidade cultural e religiosa. [...] Quando o abiã está pronto, começa o trabalho ritual. Não quero dizer que toda a vivência do abiã não tenha sido um processo ritual também. (Moreira, 2007, p. 106)

Então, ao tornar-se um noviço e ingressar nessa trajetória iniciática, recebe-se o primeiro título na hierarquia do candomblé: abiã. Mas é importante destacar também, que no panorama das diferentes modalidades de prática do candomblé - no tocante à classificação em "nações de origem étnica" (cf. Silva, 2005b; Parés, 2007) - poderemos encontrar diferentes terminologias para indicar este status do iniciante. Por exemplo, na modalidade Jeje, ocorrem também as expressões hurete (cf. Beniste, 2006, p. 313) ou oré (cf. Cossard, 2006, p. 159); nas casas identificadas como de tipologia Bantu, aparecem as expressões zenza, ndumbe ou monaxikola (cf. Beniste, 2006, p. 313); já nos terreiros do tipo Queto, é amplamente usado o termo abiã. Contudo, no dia a dia do povo-de-santo, o vocábulo abiã popularizou-se de maneira quase hegemônica entre as diferentes modalidades de culto.

Todos os grupos ${ }^{93}$ observados neste estudo empregaram a expressão abiã em tais circunstâncias. Tanto as narrativas coletadas nas entrevistas, quanto às performances observadas no campo, conferem este uso amplo da expressão. Inclusive, boa parte dos entrevistados dizia não conhecer os outros termos supracitados. Sabe-se que a origem do termo é da língua iorubá, mas não foi possível identificar se a expressão foi sempre usada com tanta frequência no candomblé, já que muitas etnografias do início do século XX (Herskovits, 1943; Landes, 1967; Rodrigues, 1935 etc.) não relatam o uso do termo nativo. Aliás, nas pesquisas sobre o candomblé, a expressão noviço(a) é utiliza de forma dúbia inúmeras vezes, ora se referindo aos não iniciados (abiãs), ora aos já iniciados (iâ̂s). Este fato confunde bastante a interpretação, posto que tratam-se de status

\footnotetext{
${ }^{93}$ Conforme já foi destacado ao longo do texto, as entrevistas e observações que fazem parte desta pesquisa correspondem à modalidade Jeje-Nagô. Portanto, as terminologias, assim como os conteúdos mitológicos que utilizo, são de uso comum a todos os participantes do estudo. Todos estavam afinados com a modalidade Queto em relação às práticas que importam para este estudo. Outras modalidades como a Bantu não fazem parte do escopo deste estudo.
} 
hierárquicos completamente distintos.

No entanto, até mesmo na modalidade de culto lessé egúngún, há um termo específico para identificar os não iniciados no culto, mas que estão na primeira escala hierárquica. Os termos amuxã (cf. Cacciatore, 1977) ou amúìsan (cf. Santos \& Santos, 1981) designam os jovens aprendizes que se preparam para o culto aos ancestrais. Após o rito iniciático, mudam de status religioso sendo chamados então de ojés. Da mesma maneira que no candomblé, a trajetória religiosa do fiel é feita de estágios hierárquicos, podendo o devoto permanecer também, eternamente no estágio inicial de abiã. Além do que, este primeiro estágio é farto de aprendizados rituais, mesmo que parciais.

No candomblé, a feitura é o primeiro rito de passagem que demarca uma mudança de status entre os membros de um terreiro. Os abiãs, portanto, integram a categoria dos postulantes, pré-iniciandos, e aspirantes, até o momento em que se concretize esta feitura, na qual reclusão e raspagem dos cabelos demarcam simbolicamente um "separar do mundo anterior" e um "ligar-se ao mundo sagrado" (cf. Gennep, 2011, p. 143). A epilação e o claustro ritual acabam por se constituírem como símbolos máximos dessa experiência. E, sem ela, os abiãs ainda permaneceriam numa zona intersticial, ou seja, um "transitante" (cf. Turner, 2013) entre os visitantes e os iniciados.

Como destaca Bastide (2006), os abiãs constituiriam uma "espécie de 'reserva' permanente de filhas possíveis dos deuses" (Bastide, 2006, p. 240). A ideia de reserva já estava presente igualmente na única observação que Edison Carneiro havia feito em 1948, sobre a presença das abiãs nos terreiros como uma "força de reserva", pois "em último lugar, ficam as abiãs. Elas não pertencem ainda, realmente, ao candomblé. Estão num estágio anterior à iniciação. [...] São uma reserva de efetivos, de potencial humano para os candomblés de amanhã" (Carneiro, 2008, p. 123-124).

Por estar num período intermediário, sua condição é de total ambiguidade dentro do grupo religioso, pois seus laços com a comunidade litúrgica são ainda demasiado tênues. Há na condição dos "de fora" ou dos "de dentro" ainda não iniciados, a possibilidade sempre virtual de jamais passarem pela iniciação, o que nos leva a pensar sobre "a linha que opera a passagem de um estado ao outro" (Segalen, 2002, p. 50). Estar abiã é posicionar-se nessa linha diferenciadora e enigmática, quanto ao que está além dela. Os abiãs sentem-se sempre diante de 
uma zona de grande mistério:

Você aprende até onde você pode aprender. Os limites do abiã giram em torno da feitura do orixá pra diante. (abiã Vanise)

Tem que esperar a iniciação, a vez de saber de tudo. Saber de tudo não, começar a saber os mistérios, né? [...] E abiã pra mim é isso. Eu acho que a gente não deve se aprofundar em nada. Tem que esperar a vez de ter conhecimento. Pra mim é isso. (abiã Regina)

É o iniciante, né? Como se diz, é uma pessoa cru! Que tá começando, pegando um caminho. Que não sabe até onde vai. Na minha... isso no meu entendê, eu entendo isso. Começando. Você vai pegar uma estrada, você pega o início, mas não sabe o fim". (abiã Janete)

Esta profunda incerteza dos próximos passos de suas trajetórias, faz com que a expressão dos olhares dos abiãs condense curiosidade e insegurança. Seja no corpo desequilibrado nas danças do xirê ou no turbilhão de sentimentos e sensações conflitantes, eles circulam nos "bastidores" do terreiro num desconforto interior que somente a sonhada feitura poderia arrefecer. Nos cantos, nas bordas e nos silêncios, os sentidos dos abiãs se aguçam gradualmente para, ao mesmo tempo em que absorverem aquele novo universo, se deixarem também serem absorvidos por ele:

É a pessoa que tá aprendendo tudo que pode consumir ali na casa de santo. Aprender a observar muito. Não falar. Observar bastante. Tudo que pode pegar de informação. Pra mim sê abiã é isso. É aprendê. [...] Conhecê a casa, conhecê tudo. Você realmente se inteirar das coisas. (abiã Priscila)

Em muitas tentativas de compreender e explicar a condição dos noviços nas religiões de matrizes africanas, diversas pessoas lançam mão de uma contraposição destes ao conhecimento oculto desta religião iniciática. É como se o abiã fosse definido pelo acesso altamente restrito ao segredo que sustenta toda a liturgia. No período inicial de sua experiência na religião, os abiãs associam a ideia de segredo à aquisição de informações valiosas para a prática ritual. No entanto, iniciar o abianato, é mergulhar num mundo de segredos que não é apenas a linguagem verbal que poderá revelá-los, pois no candomblé múltiplas formas de linguagem se integram:

O segredo circula enquanto tal, sem a finalidade da revelação. No discurso do segredo [...], as palavras estão no mesmo plano que os gestos, os deslocamentos do corpo, os sons, os objetos, os cânticos, o sopro vital (pois tudo isso pode conduzir axé), que reconstroem ritualisticamente, por "feitiço", o mundo. (Sodré, 2005, p. 122) 
Sendo assim, para se aproximar deste "mundo de segredos" na condição de abiã, não há um perfil específico para o religioso. O ingresso no abianato é possível para pessoas de qualquer idade, gênero ou condição social. Cabendo também destacar, que o seu período de duração não é predeterminado. Esta experiência pode ser de alguns dias ou de muitos anos. E, não se pode esquecer, prolonga-se eternamente em alguns casos. Embora um pouco raro, há abiãs que passam a vida inteira no terreiro sem jamais realizarem a feitura. Durante esta pesquisa, não conheci nenhum caso desses, mas ouvi algumas histórias. Porém, essa demora em realizar a feitura parece ser cada vez menor, conforme a abiã Odete fez questão de frisar. Numa conversa com pai Carlito, pude compreender que o avançar na "carreira" religiosa depende da disponibilidade do fiel, mas há sempre uma intervenção da divindade a influenciar no rumo dos fatos:

Dificilmente vai existir um abiã que o orixá deixou ele ficá a vida inteira numa casa e não cobrar. Porque o orixá ele sempre quer, né... que seu filho, ele se inicie para que ele possa evoluir dentro da casa. Porque o abiã, ele fica limitado a certos conhecimentos. O abiã fica limitado a certas funções. O abiã fica limitado a certos fazeres, afazeres. O orixá quer que seu filho, ele faça parte da casa de uma forma completa. Então dificilmente vai existir um abiã que o orixá não queira que ele se inicie. É mais fácil existir uma abiã que não foi feito, que não se iniciou porque ele optou não se iniciar ou por algum problema particular da vida dele. O período vai depender do abiã. Da pessoa estar preparada ou estar disponível para tal. (pai Carlito)

Tudo dependerá de muitos requisitos, que vão das condições materiais dos adeptos, até suas predisposições espirituais. Vários autores apontam que, há bastante tempo o candomblé deixou de ser uma religião com adesão marcada apenas por um traço étnico ou social (Contins, 2015; Duccini, 2016; Prandi, 1991, 1996; Lima, 2010). Na literatura sobre o tema, encontram-se expressões como "religião popular" (cf. Lima, 2010) ou "religião universal" (Prandi, 1991, 1996; Silva, 1995) expressando esta ampla abrangência de devotos. Para além desta diversificação do perfil dos novos fiéis, os profícuos diálogos que os terreiros têm mantido com o espaço público, reiteram este caráter mais abrangente e plural das religiões afro-brasileiras na atualidade:

Trata-se de uma espécie de diálogo que se estabelece com o grande público e que não fica mais restrito às pequenas casas ou terreiros [...] O que se observa hoje são diferentes casas de Candomblé e Umbanda no Rio de Janeiro que privilegiam a relação com o mercado, com a universidade e com os movimentos negros. A participação e o reconhecimento de pesquisadores nesses terreiros também contribuem para a sua visibilidade. (Contins, 2015, p. 77) 
Entretanto, mesmo com essa mudança radical do perfil dos terreiros, algumas características marcantes do ethos do povo-de-santo ainda permanecem "vivas". Um exemplo disso é a existência de uma espécie de chamamento do orixá (cf. Goldman, 1987), ainda bastante recorrente nas biografias religiosas. Como afirma Vivaldo da Costa Lima, "a filiação ao grupo é voluntária, mas determinada por fatores psicossociais e culturais que fazem do ritual de iniciação, da feitura do santo, um corolário comportamental lógico" (Lima, 2010, p. 266). $\mathrm{Na}$ opinião deste autor, a convivência familiar é também um fator bastante relevante para a adesão de alguns indivíduos.

Os depoimentos de vários abiãs mostraram ao longo deste estudo, que o fator familiar pode ser determinante, quando se frequenta os terreiros com a família desde a infância, ou mesmo, quando se adquire a chamada herança espiritual. Vários desses casos apareceram neste estudo, como o abiã Afonsinho que herdara o suposto dom do avô; a abiã Odete que herdara da bisavó, também iniciada no candomblé; ou mesmo a abiã Regina, que credita uma relação estreita entre um tio pajé e sua "missão" no culto aos orixás. Inclusive, no caso de mãe Dora, o legado espiritual familiar foi sua maior motivação para ingressar na "carreira" sacerdotal.

Uma ressalva importante merece ser feita a respeito de uma significativa mudança em relação às condições de gênero dos iniciados na religião. Em grande parte da literatura precursora no estudo do candomblé (Bastide, 1971; 1973; 2001; Carneiro, 2008; Herskovits, 1943; Querino, 2013; Pierson, 1942; Rodrigues, $1935)^{94}$ vemos a proeminência da presença feminina dentro do culto nas primeiras décadas do século XX. Desta forma, por um longo tempo, as referências ao noviciado utilizavam sempre termos no gênero feminino, como as noviças, as filhas-de-santo, as sacerdotisas, as iniciandas (cf. Rodrigues, 19350) ou mesmo as dançarinas dos deuses (cf. Pierson, 1942). Novamente, podemos destacar o uso confuso do termo noviça(o) referindo-se tanto às abiãs, quanto às iâ̂s. Foi a antropóloga Ruth Landes quem primeiro atentou para a crescente adesão masculina ao candomblé da Bahia. Em sua etnografia "A cidade das mulheres"

\footnotetext{
${ }^{94}$ Datas das edições consultadas.

${ }^{95}$ Ruth Landes realizou seu trabalho de campo entre 1938 e 1939 em terreiros da Bahia. A primeira publicação em livro foi uma versão em inglês em 1947. A primeira edição brasileira foi em 1967.
} 
percebe-se também o estremecimento causado por esta entrada dos homens numa religião toda estruturada para a figura feminina, como pensavam as sacerdotisas das ditas casas tradicionais:

Esses sacerdócios nagô na Bahia são quase exclusivamente femininos. A tradição afirma que somente as mulheres estão aptas, pelo seu sexo, a tratar as divindades e que o serviço dos homens é blasfemo e desvirilizante. Embora alguns homens se tornem sacerdotes, a razão, ainda assim, é de um sacerdote para 50 sacerdotisas. Muita gente acha que os homens não devem tornar-se sacerdotes e, em consequência, um homem alcança esta posição apenas sob circunstâncias excepcionais. De qualquer modo, jamais pode funcionar tão completamente como uma mulher. (Landes, 2002, p. 321)

Ainda a esse respeito, há um artigo clássico de Giselle Cossard-Binon (1981) intitulado "A filha-de-santo", no qual a antropóloga destaca o papel das filhas-de-santo como "elemento essencial de acesso ao divino" no candomblé (Idem, 1981, p. 151). No mesmo texto, a autora aproveita para chamar a atenção do uso ainda corrente da terminologia iâo - que em iorubá, significaria "esposa do orixá" - para identificar as pessoas iniciadas no candomblé. Apesar da antropóloga, já no primeiro parágrafo, alertar para o fato de que pode haver filhos ou filhas-de-santo, no desenrolar do texto, a referência à iniciação está estritamente associada à figura feminina: “A iniciação tem por objetivo condicionar a pessoa escolhida - em geral uma mulher - de modo que ela entre em transe no momento desejado e em circunstâncias precisas e muito controladas" (Cossard-Binon, 1981, p. 129). Outro aspecto curioso do mesmo artigo é a ausência de menção ao status de abiã, já que o tema central do texto é o processo iniciático das filhas-de-santo. Como em outros casos, o abianato não é posicionado aqui como primeira etapa do longo processo iniciático. Nesta narrativa, novamente, a iniciação é vista como dissociada do período preliminar, ou seja, o abianato.

Antes de avançarmos, caberia citar o inusitado uso da metáfora "escrava" para se referir ao status de abiã na vida religiosa do candomblé, conforme observado por Roger Bastide, em suas incursões etnográficas finais em 1973. No artigo "As escravas dos deuses", o autor revela ter demorado um bom tempo para perceber no campo a relativa diferenciação entre as iniciadas e as postulantes. Em verdade, ele surpreende-se com a falta de interesse dos pesquisadores pela presença das abiãs nos terreiros, até então. Com isso, Bastide (2006) observa que uma mesma filha-de-santo atua no duplo papel de "serva" e "esposa" da 
divindade, numa oposição que é apenas de caráter cronológico e fásico, dentro do processo iniciático:

A mesma pessoa que hoje é escrava amanhã será esposa. Quando se encerra a iniciação, quem passou por ela é chamada de iaô, esposa de seu orixá. O estado de escravidão se situa entre o estado de abiã, ou seja, de candidata à iniciação, que mandou "fazer" o seu colar ${ }^{96}$ e deu de comer à sua cabeça (bori) e o estado de iaô, ou seja, durante a época de reclusão que marca o centro do ritual iniciatório. (Bastide, 2006, p. 239).

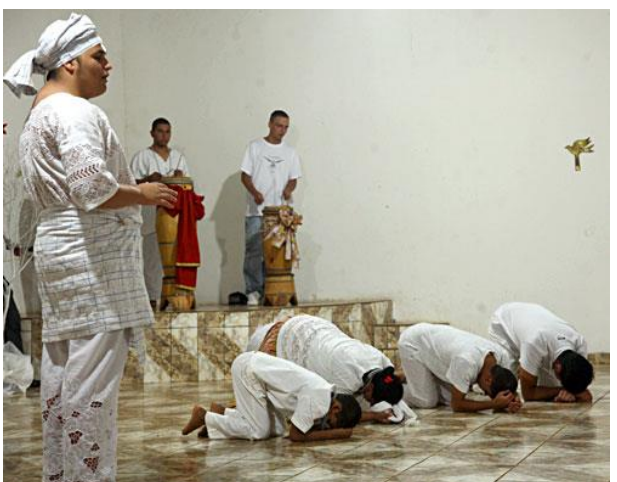

Figura 30: Abiãs e a etiqueta corporal Fonte: Google Imagens $®$
Como apontado por Bastide (2006), a relação de servidão do devoto para com as divindades começa no abianato e alcança seu paroxismo na feitura. Há inclusive um simbolismo relativo a isso no uso de uma argola de metal, denominada escrava, que é fixada no tornozelo da abiã ao longo de todo o processo ritual da feitura. Para se tornar

iâ̂, a abiã irá portar em seu corpo diversos emblemas da sujeição e obediência. O símbolo da escrava no tornozelo, por exemplo, traduz o contrato ritual eterno dos devotos, pois:

Ao sair da iniciação, a yawo [iaô] é a eleita da divindade e assim permanecerá até a morte. O que quer que faça e o que quer que pense em seguida, jamais poderá voltar atrás e desmanchar o que foi feito. Mais ainda que esposa ou filha do deus, é sua escrava. (Cossard-Binon, 1981, p. 133)

Como veremos adiante, a alusão simbólica ao advento da escravidão imposta aos africanos perpassa todas as representações contidas no ritual de feitura. No candomblé, as relações estabelecidas entre os fiéis e as divindades, sustentam-se sobre uma ideia de entrega e servidão. Os discursos dos devotos

\footnotetext{
${ }^{96}$ Há uma vasta literatura a respeito dos dois ritos propiciatórios mais difundidos no candomblé: a lavagem das contas e o bori. Estes rituais ficaram conhecidos no meio do povo-de-santo como as primeiras cerimônias que instituíam um novo fiel do papel de abiã. Hoje, não se observa mais esta obrigatoriedade nos candomblés. A lavagem das contas consiste na confecção do primeiro colar ritual da abiã, no qual o sacerdote propicia a sua imantação. Este ato litúrgico é feito no mesmo dia em que o fiel realiza seu primeiro bori. Este último, como já foi explicado em capítulo anterior, consiste em oferendas à cabeça (orî) da postulante. Em alguns terreiros, nesta ocasião são preparados também alguns assentos pessoais para que a abia cultue enquanto não passa pela feitura. O recebimento de seu primeiro colar ritual (fio-de-contas ou ilequês) é um dos momentos mais esperados no início do abianato. Há variações sobre a quantidade e a especificidade desta peça. Esses fios-de-contas são símbolo de proteção, inserção cultural, e vínculo moral com a comunidade litúrgica. Para maior aprofundamento ver: Lody (2001; 2003); Souza (2007).
} 
reforçam essa intensa relação de pertencimento ao orixá, e por isso mesmo, da consciência da autoridade dele sobre a vida do iniciado. Esta mesma servidão será projetada e materializada na relação do fiel com o templo litúrgico. Estes valores, portanto, já são introjetados bem antes da feitura, ou seja no abianato:

Ser abiã é ser um servo do orixá. É você já senti o gosto de sê um pré-iaô. Porque é isso que é sê um abiã [...] Saber que você tá embaixo agora, mas o teu orixá vai te ensiná com seus erros, com seus acertos. Não é sê o escravo. É você entendê que você é o mais novo e aquilo ali é uma parte do ensinamento. (abiã Caterine)

Acho que ser abiã é um instrumento da casa, onde você tem oportunidade de saber se é aquilo que realmente você quer. Porque o abiã é, também se torna uma mão de obra barata pro barracão. O abiã que é responsável por varrer, por lavá, por limpá, por arrumar determinadas coisas. [...] O abiã é um pouco de tudo no terreiro. (abia Afonsinho)

A gente tem que obedecer dentro da casa de santo, o que falá a gente tem que acatar, entendeu? O que mandar fazer a gente faz! (abiã Regina)

O abiã é aquela fase do grosso! Você aprende o que é o todo. Pra depois ir lapidando e começar as peculiaridades. (abiã Vanise)

Todas estas relações de subordinação são possibilitadas pela consciência de uma arraigada estrutura hierárquica. Confere-se uma dupla hierarquia no candomblé: a espiritual (na relação divindades e humanos) e a sacerdotal (entre os membros da comunidade litúrgica). O aprendizado e introjeção desta lógica começam a ser treinados já no abianato, ao contrário do que possa parecer. Os abiãs demonstram diariamente, que não é apenas na feitura que se inicia o aprendizado de uma nova visão de mundo e a construção de uma nova expressão identitária. A circulação e atuação dos abiãs no interior dos terreiros não estão livres da regulação de um conjunto de normas que constroem a identidade do ser do santo. Portanto, não é apenas na feitura que o adepto molda sua corporalidade, como podemos perceber nas conversas com os abiãs:

Você é um abiã ! Você não pode comer sentado na cadeira. Você quando fô falá tem que se abaixá. Quando você fô entregar uma água, tem que sê na bandeja. Você não pode olhá direto nos olhos do pai-de-santo. [...] O bater a cabeça $a^{97}$ é diferente. Porque o centro que eu frequentava era Queto, e hoje eu frequento o Efon. Os banhos são diferentes, o cheiro do banho é outro. A água que a gente

\footnotetext{
${ }^{97}$ Bater cabeça é uma expressão mais utilizada na umbanda, para se referir à reverência ritual na qual encosta-se a cabeça nos pontos sagrados do terreiro. No caso de Afonsinho, por ter vindo da umbanda e migrado para terreiros de candomblé em pouco tempo, percebi a utilização frequente de termos umbandistas. Sua fala representa justamente o aprendizado dessas diferentes performances religiosas.
} 
bebe é outra. O santo masculino quando vai bater a cabeça é diferente. $\mathrm{O}$ santo feminino é outro. Você tem que reaprendê tudo de novo! Sê acha que já chegou com alguma coisa, não! (abiã Afonsinho)

Eu acho que estou nascendo de novo. É tipo um nascimento. Eu vou nascer de novo. Porque eu vou aprender coisas novas. Como se eu tivesse com um ano de idade, entrando dentro desse lugar e não conhecesse nada, nem ninguém. Mas assim, vou ter que aprender tudo de novo. Aprender a falar, aprender a agir, aprender a se comunicar, aprender a fazer certas coisas, que talvez eu nem conheça, não dê muito valor. Mas eu vou ter que dar. Como se eu estivesse nascendo de novo mesmo. (abiã Devanilda)

Eu fico constrangida. Eu já falei com meu pai que é muito difícil. Porque você não sabe ali, né? Ali tem o abaixá, bate cabeça ali, bate cabeça lá. Você não sabe pra quem bater, né? Tem que ficar... e isso aí ele falou que eu vou aprender, né? Que eu vou aprender. Mas eu acho difícil! Eu não sei. Mas eu acho que eu vou conseguir sim. (abiã Janete)

Como vemos este longo processo de reeducação corporal, iniciado já no abianato, não é nada diferente do que Marcel Mauss (2003; 2012) propôs em suas reflexões sobre o uso do corpo nas sociedades humanas. Para o autor, a tecnicidade não é uma exclusividade da relação do homem com as ferramentas. Bem anteriormente a este fato da cultura, o homem manipula outro instrumento fundador: o próprio corpo. Com isso, seria um enorme equívoco acreditar que só há tecnicidade sob a condição da existência de instrumentos materiais externos ao homem:

O corpo é o primeiro e o mais natural instrumento do homem. $\mathrm{Ou}$, mais exatamente, sem falar de instrumento: o primeiro e o mais natural objeto técnico, e ao mesmo tempo meio técnico, do homem, é seu corpo. [...] Antes das técnicas de instrumentos, há o conjunto das técnicas do corpo". (Mauss, 2003, p. 407)

Entretanto, o desenvolvimento dessas técnicas corporais no candomblé, está estritamente relacionado à primeira forma de categorização dos fiéis, ou seja, os "dotes" para o transe. Na diferenciação entre os capacitados ao transe ou não, diferentes gestualidades serão desenvolvidas. Na língua do santo ${ }^{98}$ (cf. Amaral, 2002) a viração é o primeiro fator de diferenciação entre os indivíduos. Aqueles que viram, são chamados de rodantes, em oposição aos não rodantes. Usam-se expressões como virar no santo, virou no santo, estar virado no santo, para identificar os momentos em que o devoto está no estado de transe de orixá, ou

\footnotetext{
${ }^{98}$ Rita Amaral (2002) utiliza a expressão língua do santo para se referir ao léxico e o jeito de falar específicos do povo-de-santo. Ela destaca por isso os inúmeros termos africanos e a jocosidade peculiar do grupo. Ver: (Amaral, 2002, p. 84-85)
} 
estado de santo.

Assim como, a expressão desvirar o santo serve para sinalizar a reversão desse processo de transe. O desvirar pode ser espontâneo ou provocado, da mesma maneira que o transe. $\mathrm{O}$ ato de desvirar é realizado em aposentos especiais longe das vistas alheias e seguindo rigorosa etiqueta ritual. Quando diversos devotos precisam ser desvirados, é obrigatório respeitar a ordem de idade iniciática dos filhos-de-santo. Até mesmo nesse momento, o princípio de senioridade é observado. O cômodo para a execução desta tarefa, muitas vezes é o mesmo local no qual os filhos-de-santo em transe são vestidos com os figurinos dos orixás, nas festas públicas. Em alguns casos, o sabaji ou o próprio roncó transfiguram-se no "camarim da grande festa" (cf. Evangelista, 2015, p. 131). Tudo dependerá das dimensões do terreiro. Tanto no barracão de pai Carlito como no de mãe Dora, percebi o uso improvisado de algumas áreas externas do terreiro para tal fim.

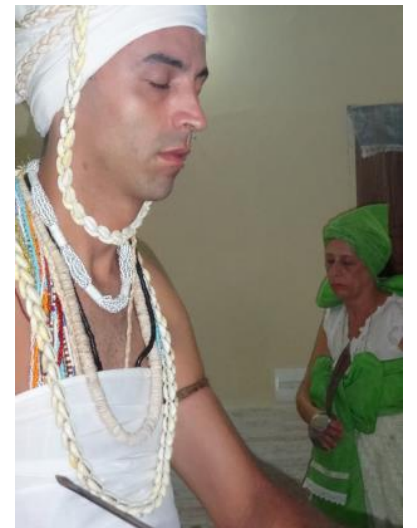

Figura 31: Devotos em transe de orixá Fonte: Acervo da pesquisa

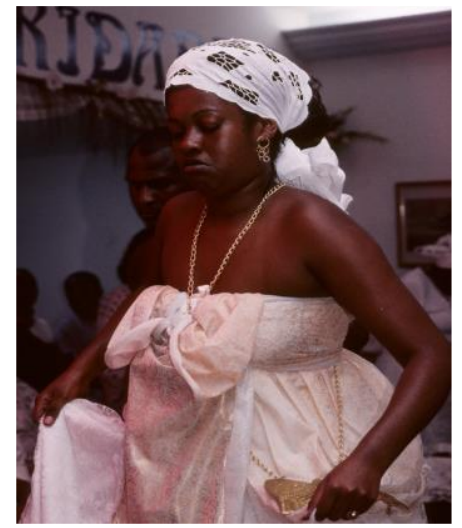

Figura 32: Devoto em transe de orixá Fonte: Google Imagens ${ }^{\circledR}$

Entretanto, ao iniciar o abianato, alguns adeptos demoram a descobrir a condição de rodantes ou não rodantes, como foi o caso do abiã Clayton, que só depois de um longo tempo foi suspenso como og a, durante uma festividade.

Aí na festa, ei fiquei pensando: Poxa, será que eu vô virar? Será que eu não vô virar? Só que eu não sabia como é que era. Aí, a festa rolando vinha um ogãa, uma equede: Não está sentindo nada não? Eu: Não. Ele: Tira o chinelo, se concentra! [...] Aí chegou ao ponto de eu falar: Vô fazer um jogo. Agora vou fazer um jogo, vou saber. Nisso ficou só no vou fazer um jogo. Não fiz o jogo. Aí fiquei ralando, trabalhando, acho que um ano e sete meses realmente trabalhando na casa. Sem saber, sem sentir nada [....] Aí depois de uma festa, acho que era uma festa de Oxosse. O Oxosse do ebôme lá de casa no meio da festa mais ou menos, ele... foi o dia que eu fui suspenso! Dali, ficou aquela coisa... sei lá... (risos) Não caiu a ficha. Eu falei: Pô, agora eu tenho a minha resposta. Eu sou ogãa! Mas, sei lá. 
(risos) Ontem eu estava o que? Limpando banheiro. Hoje eu estou sentado na cadeira no meio de todo mundo aqui me olhando. (abiã Clayton)

Há diversas maneiras de se descobrir esta primeira marca identitária no candomblé. Algumas pessoas ficam sabendo através do jogo de búzios, outras como o Clayton, durante uma festividade, quando são suspensas como ogãs ou equedes. E, como no caso de muitos rodantes, ocorre o fenômeno do bolar. Este se constitui num dos momentos mais críticos da trajetória de um religioso, sendo suplantado apenas pela experiência da feitura. Na língua do santo, o bolar é a expressão tácita da presença da divindade na vida do fiel. Todos os adeptos são unânimes ao explicar este fenômeno, como o sinal inquestionável do chamado para a iniciação. Muitos abiãs esperam ansiosos o momento de viver tal experiência:

Tava cantando pra Ogum. Eu converso muito com meu santo [...] Eu olhei nesse dia: ô meu pai, a festa do senhor, o senhor não vai vim? Não vai dá o ar da graça? Como é que é isso? Olha, se o senhor não vim eu não venho mais não (risos). E começou a tocar. Tocou a primeira, a segunda, eu me ajoelhei tava começando a tocar a terceira. Eu olhei pro meu zelador e falei: tô passando mal! Ele: tá sentindo o que? Eu: põe a mão no meu peito. O coração acelerado, minha cabeça quente. E começou a tocar. Eu lembro que eu dei o primeiro... ele saiu da roda veio pra trás de mim e começou a chamar: patacori! Ogunhêe $!^{99} \mathrm{E}$ você começa a ver tudo embaçado. Tua cabeça quente, o corpo todo... é uma energia muito grande... muito forte! E dali então eu não lembro mais nada. Acordei dentro do roncó. Que aí falaram pra mim o que tinha acontecido. Que Ogum veio, perguntaram quem era e ele confirmou que era Ogum. Eu voltei ali com aquela emoção maravilhada do mundo! É... o senhor me ouviu! Foi lindo! Eu sei que tudo tem seu tempo. [...] São desde os 13 anos! São vinte e quatro anos e até agora nada! Só tinha vindo o caboclo. E o santo de cabeça? ${ }^{100}$ Como é que é? (abiã Afonsinho)

No caso específico do abiã Afonsinho, há uma ressalva a ser feita quanto a qualidade da performance do bolar. Ele afirmava cuidadosamente que já havia "passado mal", mas nunca bolado. Ou seja, ele e muitos outros abiãs ao longo da pesquisa, descrevem com frequência esta dupla tipologia de transe bruto: "passar mal" e bolar propriamente. Constatei pelas narrativas, que no caso do bolar a performance constituía-se como uma espécie de morte simbólica, apresentando sintomas graduais de um desmaio profundo. Nesta modalidade há total "descontrole" do abiã. Já no caso do "passar mal", o abiã apresenta diversos sintomas de alteração das funções vitais, sem no entanto entrar em desmaio

\footnotetext{
${ }^{99}$ Patacori Ogunhê: saudação ritual em reverência ao orixá Ogum.

${ }^{100}$ Santo de cabeça: expressão usada para indicar o orixá protetor do fiel.
} 
profundo. Então, nesta segunda modalidade de transe bruto, a pessoa conseguiria ficar de pé e às vezes responder corporalmente às indagações de terceiros, como o pai-de-santo e os irmãos-de-santo. Mas nem por isso, os sintomas deixam de ser impactantes na subjetividade do indivíduo que "passa mal". Algumas das descrições desses sintomas são: dormência generalizada, falta de ar, tremedeira, perda de memória e equilíbrio corporal, calafrios, formigamentos entre outros. Segundo alguns abiãs, por alguns instantes é possível até acreditar que trata-se realmente de um problema de saúde, até que um sinal mais evidente do orixá esclareça o que se passa:

Comecei a me sentir muito mal. Braços dormentes... gente, vou pro hospital porque tô passando mal de verdade! Comecei a chorar compulsivamente. A equede da casa ficou sentada ali comigo no chão e eu desacordei. Fraca, fraca... parecia que ia desmaiar... fiquei desacordada nos braços dela! Ouvia tudo, mas não conseguia me mexer. Sensação claustrofóbica. Presa dentro do meu corpo! (abiã Priscila)

Estas experiências do bolar e do "passar mal" serão consideradas neste estudo a partir da perspectiva da performance, proposta por Schechner (1988, 2003, 2012 a, b, 2011). No próximo capítulo, serão analisados os componentes dessas performances dos abiãs em relação à performance dos iniciados. Como já foi pontuado em nota anterior, neste estudo, sugiro uma relação entre a performance do bolar e a performance do rum, como etapas complementares do desempenho corporal iniciático do fiel.

Por hora, importa saber que esta experiência de transe bruto dos abiãs, ocorre primordialmente em momentos festivos. Como observa Opipari (2009), "a fruição estética da música, das coreografias e das roupas é frequentemente evocada pelos abiãs como um grande atrativo e um verdadeiro prazer" (Opipari, 2009, p. 222). O intenso estímulo sensorial do xirê tem bastante influência sobre os espectadores de forma geral. Afinal, muitos visitantes bolam no xirê sem jamais terem conhecido um candomblé. Inclusive, este fato pode determinar a transformação de um visitante em filho-de-santo. É neste momento, sobretudo, que uma força centrípeta gerada pelas performances do xirê no "palco" do barracão, afeta todos os presentes:

O palco - referindo-me não apenas ao espaço físico, mas ao agregado tempo/espaço/espectador/performer - gera uma força centrípeta que engole tudo o que acontece nele ou perto dele. Esta absorção para o centro é o principal paralelo entre o processo da performance e o processo do ritual. (Schechner, 2011, p. 157) 
Uma vez abarcado por esta força centrípeta do ritual, o abiã, por ainda não ser feito, terá sua performance sempre interrompida. Na etiqueta do candomblé, apenas os adeptos feitos podem executar sua performance de orixá no decorrer das festas. Ao bolar no meio do barracão, costuma-se fazer um pequeno ritual no qual o abiã é coberto com um lençol branco, suspenso pelos ogãs e levado para o sabaji ou roncó. Nesta ocasião, será realizado um procedimento ritual para "reavivar" o devoto. Algumas vezes, o pai-de-santo ou a mãe-de-santo jogam os búzios aos pés do abiã para interpretar os desígnios das divindades. Os mais antigos no culto dizem que antigamente quando um fiel bolava durante o xirê, ele era imediatamente recolhido para a feitura de santo.

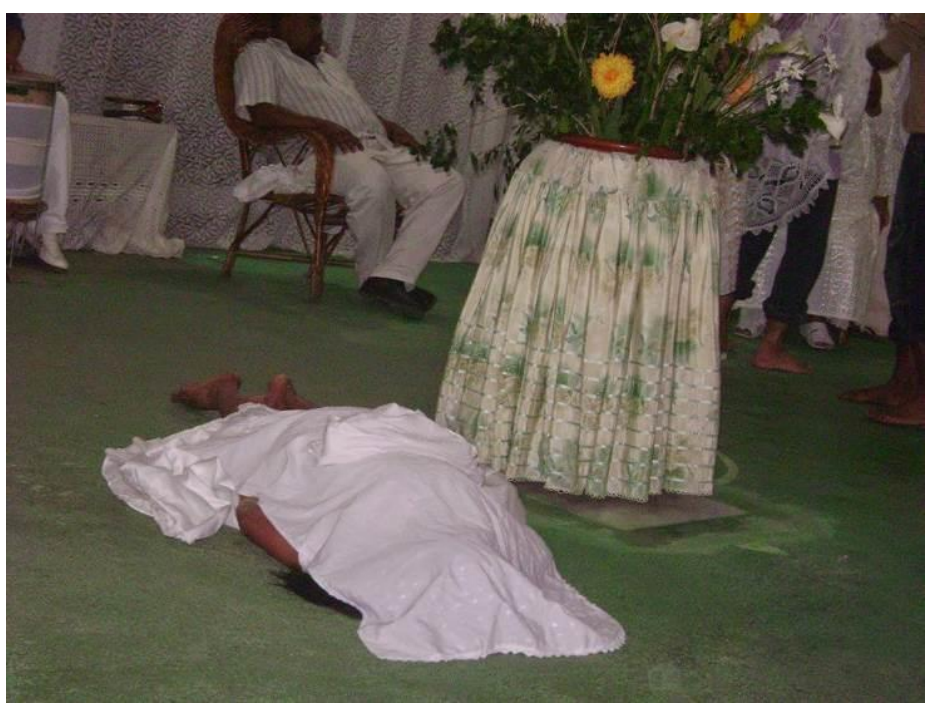

Figura 33: Abiã bolada no barracão Fonte: Google Imagens ${ }^{\circledR}$

Realmente, a simbologia é de uma morte que indica o chamado do orixá para que a pessoa seja iniciada, ou seja, renasça simbolicamente. Embora este chamado possa ser revelado pelo jogo de búzios, é no acontecimento do bolar que a vontade da divindade parece mais contundente e legítima, principalmente diante da comunidade litúrgica. Este é um dos poucos momentos em que a performance do abiã ganha destaque durante as festividades. A queda ao chão dos abiãs bolados capta imediatamente todos os olhares durante a festa. Além do que, são inúmeros os comentários ao final do evento, a respeito dos abiãs que bolaram. Pude perceber também, que a performance do bolar de um abiã, pode em certa proporção legitimar ainda mais a performance do rum de um filho-de-santo feito. Por exemplo, se durante a performance do rum de um determinado ebôme 
"caírem" dois abiãs ou mais no chão, isto poderá ser interpretado como um sinal de legitimidade da performance do rum deste ebôme. Muitas vezes ouvi comentários a esse respeito, dizendo que o santo de fulano ou beltrano era muito forte e, portanto, "derrubava" muitos abiãs. Entretanto, hoje em dia, este fato não é mais uma condição obrigatória para que o fiel realize a feitura:

O chamado do orixá não segue forçosamente uma linha evolutiva que vai de uma possessão incontrolada a seu adestramento ou controle ritual. Longe de se apresentar como uma regra obrigatória da adesão, ele surge aqui, antes como uma linguagem, como um código que assinala a importância da "feitura" enquanto legitimação ritual das competências adquiridas. Ao reforçar essa ideia de código, dir-se-á que bolar é um "alerta", um "aviso". [...] A violência da queda denota igualmente a exigência e a autoridade do santo. (Opipari, 2009, p. 218)

Importantíssimo enfatizar, que os feitos não bolam. A feitura é justamente a fase "bem acabada" de uma performance que tem seu estágio preliminar no bolar. Por isso, vejo as experiências de "passar mal" e bolar narradas e vividas pelos abiãs, como uma etapa de treinamento, aprendizado e "restauração de comportamento" (cf. Schechner, 1988, 2003, 2012 a, b, 2011), possibilitando a paulatina elaboração da performance do rum do futuro iaô. Todavia, vê-se cada vez mais uma diminuição do bolar durante o abianato, conforme também observa Opipari (2009). E, mesmo tendo bolado uma vez no xirê, os abiãs de hoje vivenciam o "passar mal" várias vezes, até o dia de suas feituras. O que também é uma atualização no universo do candomblé. Há algumas décadas atrás, um abiã bolava apenas uma vez antes da feitura, segundo mãe Dora e pai Carlito.

Em boa parte dos casos que presenciei, vi a performance do "passar mal" com mais frequência do que a do bolar, ou seja, os abiãs tem apresentado um transe bruto cada vez mais lapidado e repetitivo, ao contrário de outrora. Mas o estatuto de feito continua sendo o grande legitimador da performance de orixá. Porém, isto não diminui em nada o duplo impacto do bolar, posto que afeta os abiãs e os espectadores sempre. Como disse Opipari (2009), ele surge como um código eloquente para que todos interpretem a vontade das divindades. $\mathrm{Na}$ convivência com mãe Dora, e assistindo seu abiãs bolarem, pude compreender melhor esta linguagem do corpo desenvolvida processualmente desde o abianato:

O bolar no santo é quando a energia quer ser cuidada. O bolar não está atrelado à condição de ser feito. Ele está na condição de mostrá que existe. Tá latente. Que tá ali. Existe aquela energia. Aquela energia é presente. [...] O bolar ele é uma vivência. Às vezes é necessário que você ou bole, ou veja lúcido alguém muito querido seu bolando. [Antigamente] o santo tinha que tá presente. O indivíduo 
tinha que entrá bolado. O iniciante só entraria se a energia bolasse. Porque aí tava ali determinado que era uma vontade religiosa, uma vontade de energias [...] Ali era uma questão energética. Espiritual puro! A responsabilidade daquela energia. Então, nós zeladores tínhamos mais confiança quando um filho entrava bolado. Porque aí elimina-se noventa por cento de questões. Porque essa pessoa tem espiritualidade pra isso, não é uma vaidade. Também não é uma necessidade. Mas é uma verdade. É um fato. Uma conscientização de que existe aquela ancestralidade. Ela está ali se expondo para aquela união. Aquele casamento da pessoa com o espiritual. (mãe Dora)

Sendo assim, este é um dos fatores diferenciadores entre os abiãs, pois quando são rodantes vivenciam uma condição hierárquica completamente diferente dos ogãs e das equedes. Alguns indivíduos já ingressam nos terreiros sabendo de sua condição de ogã e equede e, portanto, de não rodantes. Neste caso, não serão tratados da mesma maneira que os rodantes, pois entre os fiéis há uma crença de que esta última categoria já nasce feita. Embora não tenha sido o caso de Clayton, algumas vezes ouvi no campo que ogãs e equedes não são abiãs, mesmo sem passar pelo rito iniciático. Este é um ponto de vista recorrente, pois também ouvi de pai Carlito, que neste caso a pessoa já "nasce grande", ou seja, traz "de berço" um cargo sacerdotal.

Mesmo sendo os abiãs o foco deste estudo, cabe uma diferenciação na trajetória das pessoas que integram este segundo grupo. O rito iniciático pelo qual passam, é chamado entre os adeptos de confirmação e não feitura. Inclusive, há muitas controvérsias a respeito desta questão (cf. Goldman, 2012). Sacerdotes mais antigos como mãe Dora, dizem que os ogãs e equedes não precisam passar por tudo que uma abiã rodante passa na feitura, como a epilação por exemplo. Por outro lado, pai Carlito defende a ideia de que todos devem passar por tudo, já que

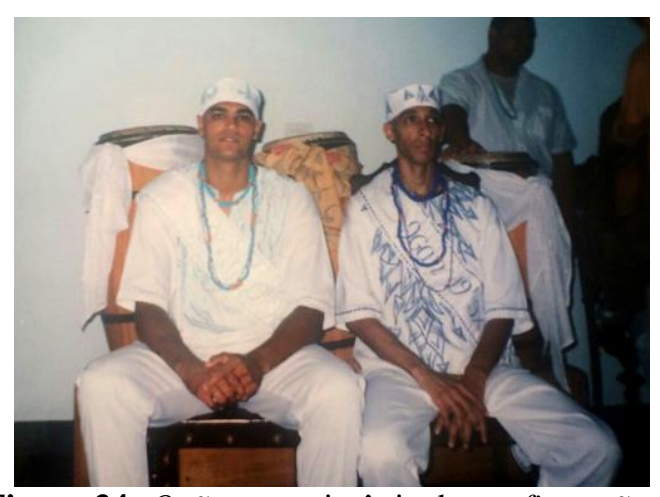

Figura 34: Ogãs em cerimônia de confirmação Fonte: Acervo da pesquisa hoje estamos vendo muitas marmotagens nos rituais, como ogãs e equedes que depois de anos, viram no santo $^{101}$. Então, para garantir a sua reputação futura entre o povode-santo, ele prefere se resguardar realizando todos os preceitos de uma feitura de iaô. A única diferença é

101 Para um maior aprofundamento deste tema, ver Evangelista (2013). A autora realiza uma interessante etnografia sobre uma religiosa que foi equede ao longo de muitos anos, porém em dado momento migra para uma nova modalidade de culto e descobre-se rodante e mãe-de-santo. 
que estes devotos não se comportarão como iâ̂s. Caso algum dia haja alguma intercorrência, ninguém poderá dizer que se trata de uma marmotagem, ou seja, de um santo de equê.

Por conseguinte, a trajetória dos ogãs e equedes, segue o padrão: apontamento, suspensão e confirmação. Um adepto pode ser apontado como ogã ou equede através do jogo de búzios ou por uma indicação direta de um orixá manifestado no corpo de um ebôme. Conforme explica Vivaldo da Costa Lima (2011), “o ogã é escolhido geralmente por um orixá manifestado numa filha-desanto [...] numa festa pública, quando a pessoa escolhida é apresentada no barracão a todos os presentes, pelo orixá que o elegeu" (Idem, 2011, p. 116-117). A suspensão é sempre pública, como ocorreu com Clayton e com Jurema. Ambos descobriram durante um xirê as suas condições hierárquicas exatas.

Na ocasião da suspensão, o orixá do sacerdote ou de um ebôme pede que o indivíduo apontado sente numa cadeira, que será levantada e apresentada aos pontos principais do barracão e à comunidade. A partir deste dia, este devoto já desfrutará dos privilégios de um ebôme, como permanecer em pé ao longo de todo o xirê e comer na mesma mesa que o sacerdote, não precisando ficar em esteiras no chão como os outros abiãs etc. A cerimônia de confirmação será realizada através de uma reclusão ritual, que vai selar o vínculo do fiel com os orixás e a comunidade litúrgica. No entanto, há uma regra no candomblé de que só é possível transmitir aquilo que foi recebido, ou seja, jamais poderão "fazer" outras pessoas, ao passo que foram apenas confirmados, e não feitos:

A carreira de um ogã ou de uma equede teria uma ascensão hierárquica mais rápida, porém limitada, pois não poderia atingir o cargo de pai ou mãe-de-santo. No caso de um iaô, a carreira levaria mais tempo, mas o adepto teria a possibilidade de chegar ao topo da hierarquia religiosa. (Evangelista, 2013, p.102)

A categoria ogã é um "nome genérico que se dá a uma série de pessoas investidas de funções rituais as mais diversas" (Lima, 2011, p. 113). De modo geral, esta categoria pode ainda estar subdividida em alguns postos como alabê (responsável pela música ritual), axogum (responsável pelas imolações animais) ou pejigã (guardião do quarto de santo). Em vários estudos sobre candomblé (Bastide, 2001; Lima, 2003, 2011), podemos encontrar informações sobre seus papeis de provedores financeiros e guardiães da segurança do terreiro, principalmente nos períodos em que houve intensa perseguição policial. 
No caso da ala feminina no grupo dos não rodantes, estas poderão ocupar o posto de equedes. A função ritual dessas senhoras é assessorar as pessoas iniciadas no momento do transe, pois "a equede é, assim, uma espécie de pajem do orixá e guardiã da segurança física e do conforto da filha-de-santo, cujo orixá a escolheu como protetora" (Lima, 2011, p. 112). Nas cerimônias de apontamento e suspensão, há sempre um orixá que será o protetor desses “escolhidos”. Isto não necessariamente terá uma relação direta com o orixá pessoal do ogã ou da equede.

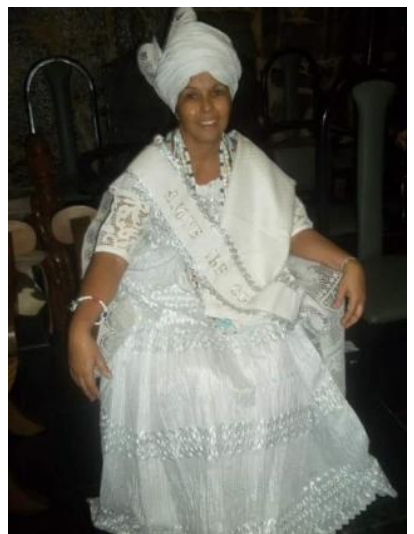

Figura 35: Equede em cerimônia de confirmação

Fonte: Acervo da pesquisa

A trajetória iniciática das equedes segue exatamente os padrões dos ogãs. Ambos, uma vez sendo apontados ou suspensos, não precisarão vivenciar toda a subordinação e obediência exigida dos abiãs rodantes. Então, esta categoria de pessoas no candomblé goza de grande prestígio, desde o momento que sejam reconhecidas nesta classificação. A superioridade hierárquica desses postos não está estritamente submetida ao ritual de confirmação, portanto, "ogãs e equedes possuem também uma posição diferenciada na ordem hierárquica do terreiro, sendo tratados como 'pais' e 'mães', sem passar pela condição de iaô, que é a mais baixa categoria no quadro dos iniciados" (Evangelista, 2015, p. 129, grifos meus).

No topo da hierarquia do candomblé, obviamente, encontra-se a liderança religiosa, que conduz o terreiro tanto no seu aspecto espiritual quanto social. $\mathrm{O}$ poder centralizado dos pais e mães-de-santo jamais pode ser questionado ou desrespeitado. Portanto, mesmo ogãs, equedes e ebômes, devem profunda obediência aos líderes religiosos de seus respectivos terreiros. Acima dos babalorixás e das ialorixás apenas os orixás:

A autoridade espiritual e moral emana direta e exclusivamente do pai ou da mãe, que só reconhece, acima da sua própria autoridade, a dos orixás. Essa autoridade - absoluta em toda a força do termo -, o chefe a divide com as demais pessoas do candomblé, em linhas muito nítidas de hierarquia. (Carneiro, 2008)

Para conseguir coordenar a exaustiva programação de atividades de um terreiro, as lideranças contam com um amplo quadro de postos honoríficos (cf. Lima, 2003; 2011), que se distribuem de acordo com as habilidades e os méritos pessoais dos fiéis da categoria de rodantes. A distribuição dos postos ocorre ao 
longo da "carreira" iniciática dos mesmos. No geral, estes cargos são outorgados pelo líder do templo ao término do ciclo de sete anos do processo iniciático. Há diversas versões entre os religiosos sobre a distribuição destes postos. Algumas pessoas explicam que são as divindades que determinam esta distribuição, enquanto outras insistem na manipulação dos sacerdotes devido diversos interesses.

São inúmeros os cargos honoríficos no candomblé, porém não aprofundaremos o tema neste estudo. Citemos alguns dos mais representativos: iyálaxé (mãe que zela pelo axé); iyáquequerê (segunda sacerdotisa do templo, mãe pequena); iyábassé (cozinheira ritual oficial do templo); dagã ou sidagã (especializada na celebração do ritual conhecido como ipadê $\hat{1}^{102}$, em reverência a Exu e aos ancestrais); babáebé ou iáebé (espécie de conselheiros da comunidade litúrgica); iyá efun ${ }^{103}$ ou babá efun (responsáveis pela pintura ritual dos corpos dos neófitos); jibonan (responsável pelos cuidados com o neófito durante o rito de iniciação), entre muitos outros. Vários desses postos honoríficos possuem dupla versão de gênero. A indicação ao cargo pode estar relacionada também à tipologia do orixá para o qual os fiéis são iniciados.

Portanto, é no bojo dessa estrutura hierárquica, que o abiã está inserido desde o momento em que ingressa como membro efetivo de um terreiro. A partir desse ponto, o abiã passa a desvendar lenta e gradualmente o lado oculto do candomblé, que como visitante nas festividades não é possível conhecer. Aprenderá inicialmente que deverá confeccionar algumas roupas próprias para frequentar o barracão nesses momentos privados do culto. $\mathrm{O}$ procedimento de chegada ao barracão também faz parte de uma etiqueta ritual rígida a ser aprendida durante o abianato.

Primeiro, assim que entrar, sentará em um banquinho para "esfriar" o corpo, sem trocar nenhuma espécie de cumprimentos rituais com seus pares. De imediato, colocará os pés desnudos no chão. Seguido deste descanso, virá o banho de $a b \hat{o}$ e a colocação das vestes rituais que lhe cabem, ou seja, a roupa de ração.

\footnotetext{
${ }^{102}$ Rito propiciatório que abre o ritual do candomblé, conforme Bastide (2001). Visa propulsionar e manter as relações harmoniosas ao longo do cerimonial. Em muitas casas é um rito solene e privado segundo Juana Elbein dos Santos (2002)

${ }^{103}$ Efun: espécie de giz mineral (cal) que é dissolvido em água para a pintura do corpo dos neófitos. Sua cor branca está relacionada ao orixá Oxalá, como símbolo da criação do mundo e dos seres. A cerimônia em que isso ocorre também pode ser chamada de efun ou saída do efun. Ao longo do processo iniciático este ritual ocorre durante vários dias.
} 
No momento das atividades privadas do templo, todos vestem igualmente estas roupas mais simples mais adequadas ao intenso trabalho que se segue. A troca das roupas civis para a roupa de ração é de enorme simbologia:

A roupa de ração coloca todos na condição de filhos-de-santo. Ao despir-se de sua roupa civil e vestir a roupa de ração, o indivíduo deixa de certo modo sua vida do lado de fora do terreiro. Aqui não há mais o publicitário, nem a doméstica, não há mais distinção entre aquele que chegou a pé e o que estacionou seu carro importado. Todos são filhos-de-santo com direitos e deveres, que vivem, é certo, sob a rígida hierarquia religiosa que lhes dita inclusive que tarefas devem cumprir, e invariavelmente todos devem colaborar com seu trabalho para a manutenção do grupo. (Souza, 2007, p. 51-52)

Espera-se do abiã que esteja presente a maior parte do tempo nas inúmeras atividades do ebé. Essas serão as oportunidades de adquirir conhecimento e de iniciar a construção de sua nova identidade. Na divisão entre atividades públicas (as festas) e as privadas (a função ou orôs) ${ }^{104}$, é no segundo grupo que o fiel conseguirá aferir sua habilidade para "as coisas do santo", como diz pai Carlito.

Cabe ressaltar que, mesmo estando presentes nesses momentos privados, aos abiãs serão impostas regras que balizam um acesso gradual a cada um dos procedimentos litúrgicos executados nesse período. Assim, estar presente no templo nessas circunstâncias, não é sinônimo de ver e participar diretamente de todas as práticas rituais. Os abiãs logo aprendem os regulamentos para dois tipos de comportamento possíveis para eles dentro do terreiro: aproximação e afastamento. A aguçada hierarquia que organiza o grupo distribui sobre os espaços e as pessoa uma aura de autoridade que precisa ser vigiada desde sempre pelos novatos, pois "a autoridade não é apenas uma atitude moral, ela faz amiúde uso da espacialidade simbólica, um uso específico dos lugares e dos corpos que nada deixa ao acaso" (Le Breton, 2009, p. 99).

Durante o abianato é preciso estar sempre atento ao que pode ser visto, ouvido e manuseado. Há lugares e momentos específicos nos quais esses abiãs podem atuar ou não. Atuar, na fase do abianato, muitas vezes pode ser compreendido como não participar ativamente dos eventos, mas estar por perto como me disse certa vez a abiã Jurema. Há momentos que o abiã permanece de longe quieto, consumido de curiosidade e deixando-se afetar pelos sons, odores ou temperaturas, de origens distantes de seu campo de visão. De modo geral, as

\footnotetext{
${ }^{104}$ Expressões sinônimas ao termo ritual.
} 
atividades que lhe competem configuram-se como tarefas satélites às ritualísticas que apresentam um gradiente de sacralidade superior. Durante o abianato sua performance está constantemente regulada por esta tensão, tanto pelos já iniciados que os observam, quanto por um autocontrole desenvolvido ao longo da convivência:

"O abiã só pode fazê funções assim... externas. Interno não pode metê a mão em nada. [...] Já entrei pra limpar quarto de santo. Não na hora do 'ato'... que eles tão fazendo os rituais lá [...] Não pode participar do ritual. Não pode tá perto. Na hora da reza interna não pode tá perto. Também não pode entrá. São coisas que nós não podemos vê. Só os iniciados pode vê". (abiã Odete)

"Porque eu sou uma iniciante dentro da roça de santo, eu acho que eu não devo, aí eu vou e pergunto! Tem muita gente que não gosta... vou perguntar pra uma pessoa que é mais elevada se eu posso entrar. Se disser: não, você não vai entrar! Eu não entro... eu não entro". (abiã Regina)

“Tarefas gerais de limpá a 'casa'... varrer, passá pano, lavá louça, fazer algumas comidas de santo. Não todas! Tem algumas que já são de grau! Não pode manusear. Não pode entrar no zacá... roncó! Nem no quarto de santo. Nem mexer nos assentamentos... entrar em contato com o iâ̂ dentro do quarto. Alguns orôs são só pra iniciados". (abiã Priscila)

A vivência do abianato é sem dúvida um descortinar dos "bastidores", mas que se pretende gradual e controlado por diversos ocultamentos. Afinal, "o sagrado precisa estar continuamente cercado com proibições [...] porque as relações com ele restringem-se [...] por rituais de separação e demarcação e por crenças no perigo de se cruzar fronteiras proibidas" (Douglas, 2014, p. 35).

Pelo discurso dos abiãs, confirmamos essa maneira típica do candomblé de "ocultar mostrando" (cf. Santos, 2005), que está profundamente imbricada com o tipo de interlocução que sempre apresentou com o espaço público. Inúmeros estudos (Sodré, 1988; Santos, 2009; Reis, 2008 etc.) detalham a forte discriminação social e perseguição policial que assombrou o candomblé até meados do século XX. Rechaçado pelas elites intelectuais e a própria violência do Estado - pois visto como um sinal de atraso cultural para a modernização almejada no país (Sodré, 1988, Maggie, 1992) - foram necessárias muitas negociações e alianças com a sociedade mais ampla, para que pudesse se manter enquanto instituição religiosa reconhecida. Inclusive, por um longo período, estes terreiros constituíram verdadeiros "guetos culturais" (cf. Contins \& Maggie, 1980), pois estavam "distantes dos centros de decisão, de emprego, do poder 
político, etc., e centralizavam a produção cultural desses grupos" (Contins, 2015).

Por ter suas práticas religiosas depositárias de traços culturais africanos num contexto social em que a África configurava um mundo de superstições grosseiras e crenças bárbaras (Santos, 2015, 129) - o binômio magia e possessão constituía o quadro primitivo e assustador da cultura negra e era considerado um de seus aspectos mais aberrantes (cf. Goldman: 1987).

Portanto, a única estratégia possível de sobrevivência cultural pareceu ser a ocultação das práticas mágicas no âmbito do privado, e a valorização do caráter festivo como faceta pública do culto. A contraposição de toda repressão engendrada ao universo cultural afro-brasileiro fomentou o acirramento de zonas de segredo no candomblé, como sua melhor estratégia de defesa, com "a criação de códigos específicos ao grupo, a manipulação do mistério e do misterioso, criando uma zona geradora do medo, fonte de perigo potencial para o 'outro"' (Pereira, 1984, p. 181).

Por outro lado, na abordagem relativizadora de Yvonne Maggie (1992), todos os mecanismos de controle criados pelo Estado a partir da República, ao invés de aniquilarem estas crenças, foram de extrema relevância para a sua própria constituição na sociedade brasileira. Como num efeito contrário, acabou por aumentar a visibilidade social dessas manifestações religiosas. E foi a festa, a faceta escolhida por "agentes internos e externos para representar o caráter religioso do candomblé" (Santos, 2005, p. 130). As festas serviram de alguma maneira para os adeptos difundirem uma imagem de fartura e beleza, contrapondo-se aos estereótipos até então relacionados ao candomblé como um "culto fetichista" (cf. Rodrigues 1935; 1977) de negros e pobres:

A festa pública tornou-se um dos principais elementos responsáveis pela publicização do candomblé na medida em que através dela a religião foi sendo integrada à vida cultural e religiosa de nosso país. As imagens produzidas pela festa, tornaram-se a face mais visível do culto aos orixás, a ponto de o termo candomblé, usado inicialmente para se referir às danças rituais, passar a ser utilizado para denominar a própria religião. (Santos, 2005, p. 131)

No entanto, o que é fundamental enfatizar é que mesmo com essa bipartição estrutural - ritos privados e públicos - ambas as etapas constituem-se como rituais, embora, na segunda o aspecto festivo seja proeminente. No tocante aos ritos privados, há um variado e complexo agrupamento de práticas, que estão basicamente constituídas assim: a) pelos rituais iniciáticos de seus adeptos; b) os 
ritos de atualização cíclica destas iniciações ${ }^{105}$ e c) a manutenção ritual da estrutura do terreiro, enquanto unidade "viva".

Como visto até aqui, os espaços do templo, assim como diversos elementos que o compõe - por exemplo: os atabaques, o chão, as árvores divinizadas etc. - passam pelos mesmos rituais aplicados às pessoas, já que o terreiro é percebido como um organismo vivo que necessita ser realimentado energeticamente. Para os adeptos, o terreiro é um verdadeiro "personagem" com o qual todos interagem. Como persona do ritual, ele recebe os mesmos cuidados dispendidos às pessoas. Algumas vezes a casa de santo é personificada também na através da própria pessoa do sacerdote.

Certa vez entrevistando mãe Dora, ela relembrava sua trajetória como substituta de sua mãe na liderança religiosa. Por motivos de doença, após a morte do marido, mãe Georgete precisou parar com o funcionamento do terreiro. No entanto, mãe Dora teve que substituí-la em acato à vontade da própria casa de axé, como ela mesma me explicou:

"Então, como a casa não aceitava... Porque a casa tem vida própria! A casa espiritual não aceitou parar. Então, neste processo, ela junto com meu zelador, me passaram a frente [...] Então, é uma herança que eu recebi da casa em vida, né? Na morte dela, isso só foi confirmado." (mãe Dora)

Convivendo com mãe Dora, fui ao poucos compreendendo o que ela pensava ao se autoidentificar como uma administradora e não propriamente líder do terreiro. Sua maneira de encarar a nova gestão do terreiro herdado da mãe seguia justamente o pressuposto de não deixar que a dimensão "espetacular" do culto tomasse proporções descabidas diante dos ritos privados com os quais a festa formava uma unidade.

Todos os procedimentos litúrgicos internos - pelos quais os fiéis e o próprio terreiro passam digamos preliminarmente - estão estreitamente relacionados às festividades públicas. Estas duas esferas do candomblé possuem sempre uma correlação direta e dialética, em que a primeira etapa pode caracterizar uma espécie de "bastidores" da segunda, na qual o público em geral poderá ter acesso. Estas fases não devem ser percebidas jamais como estanques,

\footnotetext{
${ }^{105}$ A partir do primeiro rito de passagem (feitura), o religioso irá efetuar algumas atualizações rituais: após um, três, sete, quatorze e vinte e um anos. Estes procedimentos rituais são conhecidos entre o povo-de-santo como obrigação, melhor dizendo: obrigação de um ano, obrigação de sete anos etc. No entanto, apenas a feitura e a obrigação de sete anos constituem uma modificação de status na trajetória religiosa do fiel.
} 
pois "as cerimônias, privadas e públicas, podem também se articular entre si constituindo uma unidade como, por exemplo, uma iniciação de iaô, onde a aparição pública [...] do iniciado encerra o ciclo dos rituais privados" (Silva: 1995: 122).

Sobretudo no cotidiano privado dos terreiros, muitos religiosos parecem compreender a participação como um sacrifício de seus horários de lazer e do próprio corpo investido na enorme demanda de atividades que antecedem a festa. Vendo por esta perspectiva, é fácil lembrar os princípios daquilo que Mauss (2013) nomeou como "sistema das prestações totais", ou seja, há um mecanismo de trocas que não se encerra nos limites materiais ou econômicos dos filhos-desanto. Mesmo que elementos materiais também sejam recorrentes nesse processo da reciprocidade.

Nesse fluxo de doação exaustiva e prolongada de si, institui-se uma espécie de contrato gerado pela aliança entre filhos-de-santo, sacerdotes e divindades. Participar o máximo possível do calendário, será certamente recompensado em algum momento da trajetória religiosa, seja pela retribuição dos pares ou das próprias divindades a quem eles sempre apregoam total onisciência dos fatos.

Os abiãs logo cedo aprendem que tudo que se faz no terreiro é para o orixá. Por isso, ouvi em inúmeras situações, alguns abiãs ou pessoas já iniciadas, que mesmo nutrindo certa antipatia por um determinado adepto, não deixavam de estar presente nos rituais relacionados a tal pessoa. A justificativa é sempre a de que acima de tudo, trabalha-se para o orixá da pessoa que protagoniza um ritual. Mas sabemos que em verdade trabalha-se para a pessoa também, pois "as pessoas se dão ao dar, e, se as pessoas se dão, é porque se 'devem' - elas e seus bens - aos outros" (Mauss, 2013, p. 80; grifos do autor). Indubitavelmente, esta é uma primeira lição-de-coisas aprendida pelos abiãs. O sistema de dádivas recíprocas opera aqui igualmente nos ritos de imolação animal, em que "essas trocas e esses contratos arrastam em seu turbilhão, não apenas homens e coisas, mas os seres sagrados que estão mais ou menos associados a eles" (Idem, 2013 p. 30-31).

O caráter sacrificial das atividades no terreiro é tão marcante, que o termo nativo utilizado correntemente para identificar os momentos litúrgicos cíclicos a que as pessoas são submetidas é obrigação. Diz-se entre o povo-de-santo: a obrigação de fulana, dar obrigação, fazer obrigação, pagar obrigação (no 
sentido duplo de realização e pagamento monetário) etc. Como ouvi de um abiã certa vez: "Você reparou que quase ninguém veio na obrigação da Bete? Também, ela nunca ajuda ninguém”. Como se vê, sempre há a possibilidade de rompimento desse contrato, numa forma de boicote dos filhos-de-santo.

Enfim, no desenrolar das semanas de obrigação interna nos terreiros, que antecedem o xirê, o abiã poderá compreender melhor o seu papel na trama do candomblé. Por estas e outras razões, fazer parte dos "bastidores" do "teatro" dos orixás pode ser o momento ideal para decidir entre to be or not to be abiã.

\section{3}

\section{"Orixá não nasce sabendo dançar" - Liminaridade e restauração do comportamento nos candomblés}

A sala onde acontecem as festas é um teatro. Cada cerimônia é uma representação religiosa, da qual participam atores e espectadores. [...] Por ocasião da festa, o esplendor das roupas, dos cantos e da dança, a profusão de luzes e cores satisfarão as aspirações estéticas dos participantes. Ao fazer reviver as lendas dos deuses, a coreografia assegura a transmissão do patrimônio cultural. [...] Através da fillha-de-santo, elemento essencial de acesso ao divino, a continuidade transcende a condição humana e assegura sua libertação espiritual. (Cossard-Binon, 1981, p. 130-151)

\section{- Cena 1}

Manhã de festividade no terreiro de mãe Dora. Ou, como ela várias vezes me corrigiu, de orô! O quintal estava repleto de carros como de costume. Dia de candomblé os cachorros ficam presos, cedendo lugar à família-de-santo e seus convidados. O cheiro de azeite de dendê tomava conta do ar. Pela fresta da porta do barracão interno, viam-se dezenas de tigelas de barro com as comidas de santo $^{106}$ com sua típica estética elaborada pelo esmero das filhas-de-santo. Era um sábado quente de Agosto, no qual a sacerdotisa realizava seu tradicional olubajé $^{107}$. Como de costume, pelo grande abafamento do barracão, mãe Dora

\footnotetext{
${ }^{106}$ Comida-de-santo: expressão usada para indicar a gastronomia ritual do candomblé. Cada divindade possui uma série de pratos que representam, através da estética dos ingredientes, suas preferências culinárias e características arquetípicas. Tudo que se realiza na liturgia do candomblé é composto de diversos destes pratos rituais.

${ }^{107}$ Olubajé: festividade em honra do orixá Omolu ("senhor da terra"). Consiste num grande banquete feito com a comida ritual de quase todos os orixás do xirê. É organizada uma mesa sobre esteira no chão, de onde todos provam as comidas seguindo uma etiqueta ritual própria. Os fiéis acreditam que além desta divindade estar relacionada à terra, o sol seja também um de seus domínios na natureza.
} 
preferia tocar a macumba no quintal, onde sempre era mais ventilado. Além do que, por ser uma festividade de Omolu, o ritual deveria mesmo ser executado sob o sol. Como era contra os excessos "espetaculares" que tomavam conta do candomblé ultimamente, a mãe-de-santo não usava mais os atabaques, e por isso, as rezas e os cânticos em iorubá ritmados pelo agogô, não incomodavam tanto a vizinhança da vila na qual sua residência e terreiro se localizavam.

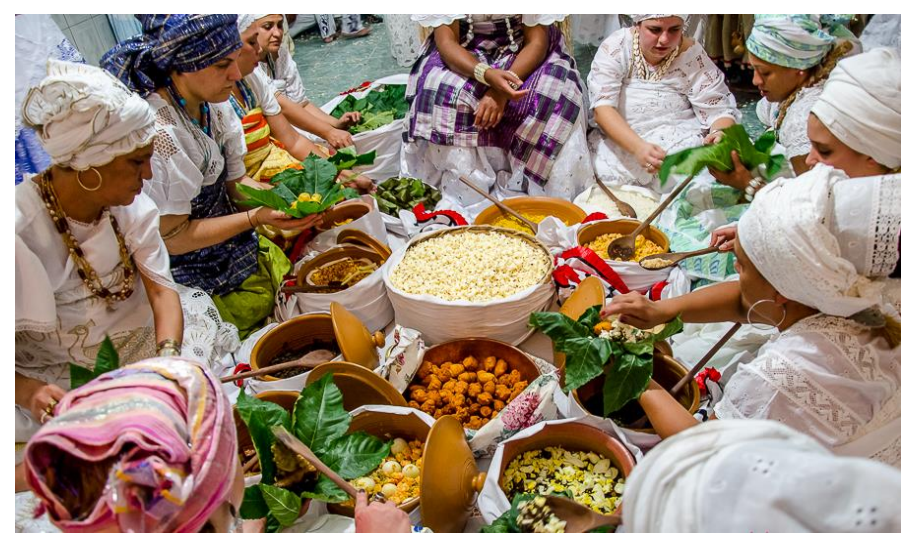

Figura 36: As comidas-de-santo no ritual do Olubajé Fonte: Google Imagens $®$

A mesa do olubajé já havia sido suspensa, quando percebi a abiã Vanise passar ofegante com seu pano-da-costa ${ }^{108}$ branco no dorso. Atrás dela, alguns outros abiãs com os olhos esbugalhados, sempre atentos a uma ordem dos ebômes ou da mãe-de-santo. O dia de festa sempre gera certa tensão nos "bastidores". É como se em cada cerimônia pública, toda a reputação do terreiro estivesse sob risco. Ao término do banquete do rei ${ }^{109}$, todos os presentes encostaram-se nas pilastras abrindo um grande círculo para que a corte ${ }^{110}$ dos orixás passasse para o rum final da festividade do dia. Sendo um dos momentos mais esperados, vários

\footnotetext{
${ }^{108}$ Pano-da-costa: pano retangular de diversas cores e texturas que compõe o traje típico da baiana. $\mathrm{Na}$ época colonial era importado da África (Costa da Mina). É usado para cobrir os seios e o ventre das mulheres no candomblé. Aquelas com maior idade iniciática podem usá-lo na cintura ou pendurado ao ombro. Pela forma de seu uso no corpo, é possível reconhecer logo a posição hierárquica do devoto. Esta peça ritual, embora muitas vezes bastante luxuoso, não constitui um mero adorno. Há uma relação simbólica entre o ventre feminino como fonte de vida e morte (sangue menstrual). Por isso, no cotidiano do terreiro, todas as mulheres precisam usá-lo. Maior aprofundamento ver: Lody (2003).

109 Banquete do rei: outra expressão utilizada para olubajé. Omolu também é conhecido como Obáluaiê, que significa o "rei da terra". Para maior aprofundamento ver: Barros (2005).

${ }^{110}$ Corte dos orixás: expressão usada no candomblé para indicar o momento em que os filhos-desanto em transe de orixá retornam ao salão paramentados para "dar rum". A corte é configurada por uma espécie de fila indiana na qual os orixás estão organizados numa sequência hierárquica mítica. É um momento de grande efusão no candomblé. Todos se levantam em reverência e começam a comentar a beleza e o luxo das vestes rituais.
} 
visitantes e filhos-de-santo sacavam seus celulares para tirar fotos das performances de orixá dos devotos.

Com o desenrolar da dança e da alegre louvação, muitos fiéis se emocionavam, num crescente de palmas e saudações aos orixás. A festa parecia atingir seu clímax com a dança de Omolu. Os corpos suados esbarravam-se no espaço exíguo, que permitia aos presentes um breve contato mais íntimo entre desconhecidos. Porém, neste contexto, o suor é axé! Mas a vibração que preenchia a cena parecia integrar performers e espectadores num corpo único. Cada abraço de um orixá transfigurava o semblante de quem o recebia.

Chegando quase ao final do xirê, um visitante virou no santo em meio aquele tumulto festivo. A cada vez que um novo fiel vira no santo, os olhares do público deslocam-se das performances do rum, para identificarem no novo foco o orixá que se apresenta. $\mathrm{O}$ momento da viração, por mais rápido que seja, é sempre uma performance solo do devoto. No meio do público podia-se ouvir os palpites: “É Ogum! Não, né não. Acho que é Oxaguiã!”" O povo-de-santo tem sempre um olhar treinado para fazer a leitura dos códigos do corpo. Tudo pode ser um sinal: os fios-de-contas, as expressões faciais do fiel em transe, a cor e forma do pano amarrado rente ao corpo ou um brado que corta o espaço e arrepia a pele de quem comunga da performance.

Neste ínterim, a equede Sueli correu o olhar a procura de um pano para atracar $^{111}$ o orixá recém chegado. Num lance, a abiã Vanise tira seu pano-dacosta para emprestá-lo à equede. No mesmo instante, Vanise é tomada por seu orixá. Como ela mesma narrou após o transe: "parece que seu corpo mesmo, não é o seu corpo". De repente aqueles abiãs que passam tão desapercebidos ao longo da exuberante beleza da festa, "roubam a cena" nos segundos fugazes do bolar. Como sempre acontece quando um abiã bola, todos os olhares se voltaram para Vanise. Vi que mãe Dora pediu que dois ebômes - iniciados para o mesmo orixá de Vanise - entrassem com ela para o barracão afim de desvirá-la.

No entanto, para a surpresa de todos, os dois ebômes também viraram ao tocá-la. A abiã Priscila que estava à espreita de tudo, correu para avisar mãe Dora

\footnotetext{
${ }^{111}$ Diz-se atracar ao ato de utilizar uma tira de pano para ornar o corpo do devoto em transe. O pano atracado opera como uma modalidade simplificada da veste ritual. Para cada divindade há uma maneira específica de atracar estes panos. Os códigos do vestuário ritual são aprendidos ao longo da convivência. No dia a dia das festas, os abiãs logo começam a aprender estes signos. Geralmente, são as equedes as responsáveis por fazerem isso.
} 
do acontecido. Ao chegar diante dos três orixás, a sacerdotisa compreendeu o fato como um sinal da divindade de Vanise. Usando artifícios da etiqueta ritual, indagou ao orixá qual seria sua vontade. Segundo me explicou a abiã Vanise posteriormente, aquele havia sido seu ultimato para a feitura.

\section{- Cena 2}

Naquela noite chuvosa de outubro, o terreiro estava enfeitado com muitos vasinhos de flores para a festa da obrigação do pai-de-santo do abiã Afonsinho. $\mathrm{Na}$ verdade, ele era filho-de-santo de pai Flávio, que ainda não tinha um terreiro aberto. Portanto, este era o barracão de seu avô-de-santo, o pai Edivaldo. O templo localizava-se numa rua residencial pouco movimentada. Quem passasse na porta, nem reconheceria de imediato que se tratava de um terreiro, a não ser nos dias de toque. A música é sempre um elemento que denuncia a presença do candomblé. Os muros eram altos e o portão de ferro hermeticamente fechado. A fachada toda pintada de branco: muro e portão. Durante o candomblé era necessário que um abiã ficasse atento à campainha. A cada vez que um convidado chegava, era preciso sair do barracão para abrir o portão. Na verdade, na parte da frente do terreno era a residência de pai Edivaldo, o que justificava o portão sempre fechado à chave.

Depois de passar por um longo corredor, é que chegávamos ao barracão propriamente dito. Nesta passagem, o cheiro convidativo dos salgadinhos e da janta nos acompanhava até o salão principal. A cerâmica brilhosa que revestia o piso, assim como todas as dependências do terreiro, era mantida limpa com um capricho muito grande dos filhos-de-santo. Afonsinho já havia falado bastante da mania de limpeza do avô-de-santo. Os abiãs trabalhavam muito para atender às exigências do velho sacerdote. Ao passarmos no corredor lateral que dava acesso ao salão do barracão, via-se pela janela da cozinha, os panelões ariados impecavelmente. Coisa difícil no candomblé, devido à espessa fuligem que estraga as panelas colocadas no fogo à lenha, nos dias de imolação ritual.

O terreiro era bastante pequeno e quente, mas a recepção era farta e aconchegante. $\mathrm{O}$ avô-de-santo de Afonsinho era conhecido pela fartura excessiva nas festas de orixá. Pela primeira vez conheci um barracão, que no término das festas, oferece uma sacola plástica e uma quentinha de alumínio, para que todos os visitantes levem uma marmita com bolo e docinhos para casa. Um pequeno regalo 
para se sentirem em casa. Afinal, casa e família são dois conceitos valiosos para o povo-de-santo. $\mathrm{O}$ avô-de-santo de Afonsinho sempre discursava dizendo que não tinha o menor interesse em ter a casa cheia de gente. Porém, nas festividades que frequentei lá, havia sempre uma quantidade exageradamente farta de comida, como se estivessem esperando muito mais do que as 10 ou 15 pessoas que vez ou outra apareciam por lá.

Assim que cheguei naquela noite, logo percebi que Afonsinho estava um pouco contrariado. Diferente de seu comportamento habitual estava calado e com um semblante fechado. Como eu já imaginava o trabalho intenso que haviam tido ao longo das duas semanas que antecederam a festa, pensei tratar-se apenas de cansaço. Mas logo que o xirê começou, fui mudando de opinião.

$\mathrm{O}$ toque dos atabaques precipitou o xirê. $\mathrm{Na}$ roda-de-santo, os fiéis da casa e alguns convidados dançavam. Notei que Afonsinho entrava e saía da roda diversas vezes. Pai Edivaldo toda hora chamava-o e cochichava algo em seu ouvido, e lá ia Afonsinho: abria portão, servia refrigerante, secava o chão, tirava foto, colocava papel higiênico no banheiro, servia salgadinho, trocava o galão de água do bebedouro, servia água aos ogãs e voltava para roda, ofegante. O xirê avançava. Alguns filhos entravam em transe. Palmas, flashes e saudações aos orixás vinham da audiência.

As primeiras cantigas referentes ao seu orixá, Afonsinho escutou com os olhos arregalados entre uma tarefa e outra, bem longe da roda-de-santo. E assim, passou todo o xirê na expectativa de voltar ao salão, para sentir a energia de seu orixá. Para vibrar, cantar e quiçá bolar. Nesta fase do abianato, era tudo o que Afonsinho mais desejava. Embora não fosse feito ainda, ele acreditava que aquele momento também era importante para um abiã. Ele sabia que as pessoas não estavam ali para assisti-lo, já que como abiã seu santo jamais daria rum. No entanto, da perspectiva do abianato, o jovem postulante pensava que o maior sentido de estar ali encontrava-se na cena que ele próprio presenciaria no seu corpo. Como ele mesmo me revelou: "foi muito bonito, só que o pouco que eu esperava pra mim do sentir a energia, a vibração do meu santo... eu não pude nem me concentrar!".

Naquela noite, tudo se resumiu em muito trabalho e contrariedade para Afonsinho. Como me revelou posteriormente, a rixa entre ele e pai Edivaldo, que começara durante a semana, passou dos limites naquela festa. Passados alguns 
dias, o jovem abiã pediu afastamento definitivo do terreiro.

\subsection{1}

\section{Raspado, catulado e adoxado - A construção da performance do rum}

Como esclarecido no capítulo anterior, nas festividades públicas do candomblé as danças compõem o núcleo da liturgia. No entanto, há uma regulação clara a respeito daqueles que podem executar as performances do rum que serão assistidas pela plateia de visitantes. Logo no início do xirê, todos os membros do ebé participam das danças de entrada (cf. Zenícola, 2003; 2007), que operam como um aquecimento facilitador do transe de orixá ${ }^{112}$ daqueles fiéis já iniciados, ou seja, dos ditos feitos. Somente esta categoria de pessoas poderá expor no barracão a dança de seus orixás pessoais através do transe.

Aos não iniciados, resta a participação através das palmas e dos cânticos. É nesse momento que os abiãs comportam-se como uma espécie de "públicoassistente" (cf. Silva, 2007) juntamente com os visitantes. Portanto, é uma excelente oportunidade para os abiãs absorverem pela observação, não apenas a etiqueta ritual de atuação no barracão no ambiente festivo, como também o padrão gestual da performance do rum de cada adepto-orixá ${ }^{113}$. Enquanto essas danças rituais se desenrolam, o fluxo da ação (cf. Schechner, 2011) que compõe o processo ritual propicia que alguns abiãs envolvidos "bolem" no chão do barracão. Então, as performances do rum são momentaneamente atravessadas pelas performances do bolar ou "passar mal"114, dos abiãs ou algum visitante, que também estão suscetíveis a mesma experiência. Imediatamente, são tomadas as

\footnotetext{
112 Transe de orixá ou estado de santo: neste estudo, usarei ambas as expressões com a mesma acepção. Ao longo da pesquisa, percebi que os termos orixá e santo eram utilizados concomitantemente de forma abrangente por todos os participantes. Mas há na literatura registros de uma diferença de concepção em torno destes termos. Através da iniciação ritual, o orixá enquanto princípio genérico da natureza é singularizado como santo na cabeça do iniciado. Como explica Opipari (2009, p. 196), podemos considerar o ritual da feitura como uma atualização do orixá que existe em virtualidade.

${ }^{113}$ Binômio utilizado para se referir ao adepto em transe de orixá, que é percebido pelos religiosos apenas como o orixá ou santo manifestado.

${ }^{114}$ Conforme explicitado em capítulo anterior, as expressões bolar e "passar mal" estão relacionadas ao fenômeno do transe bruto, ou seja, o transe vivenciado pelos abiãs antes de passarem pela feitura, na qual o estado de santo é disciplinado segundo uma estrita etiqueta ritual. Vale lembrar, que esta diferenciação entre bolar e "passar mal" foi feita pelos religiosos que entrevistei. Ela representa uma sutil gradação na performance do bolar, que pode ser mais ou menos "violenta". Em alguns casos, como o da abiã Paula, dizer que o santo passou também denota esta suavidade do "passar mal".
} 
providências rituais em relação aos abiãs bolados, tendo continuidade o xirê.

Entretanto, nesta sessão, interessa-nos apenas contextualizar brevemente o processo iniciático que leva os devotos a construírem suas performances do rum. Sendo a preocupação primordial deste estudo a fase que antecede o rito iniciático propriamente dito do candomblé, a seguir iremos apenas delinear os aspectos mais relevantes do rito de feitura que prepara e autoriza o devoto para sua performance do rum. Estas breves considerações são importantes para entender melhor o papel da performance do bolar vividas durante o abianato.

Na cosmologia dos cultos de modalidade Jeje-Nagô, há uma narrativa ${ }^{115}$ segundo a qual foi dada à divindade Oxum a incumbência de preparar um ser humano de excepcional caráter, para transformá-lo no primeiro sacerdote do culto aos orixás na terra (aiê). Decidido de que os seres humanos deveriam oferecer sacrifícios, para restituir à natureza parte daquilo que consomem dela, Olorun viu na criação do culto aos orixás a melhor solução para isto.

Oxum era a responsável pelo poder de procriação dos seres e, portanto, por toda a descendência na terra. Desta maneira, a divindade patrona da gravidez cumpriu a missão determinada por Olorum. Um jovem rapaz foi cuidadosamente escolhido para morar com ela e durante sete anos receber todos os ensinamentos necessários para evocar o axé de cada um dos orixás, para apaziguá-los e torná-los propícios para o desenvolvimento da humanidade.

Com a passagem dos anos, o sábio sacerdote tornou-se um ancião bastante debilitado. Oxum ficou bastante desolada com a impiedosa ação do tempo sobre seu pupilo, que a finitude da condição humana acabaria por subtraí-lo do aiê. Foi então, que Oxum teve a ideia de criar um símbolo que perpetuasse este primeiro sacerdote criado por ela. A galinha d'angola passaria a partir daquele momento a ser o símbolo vivo do primeiro sacerdote que havia morrido. Este animal representaria não só a presença do pupilo, como de todos que um dia receberam no alto da cabeça o sagrado $o x u$, cone simbólico da aliança entre um iniciado e seu orixá.

\footnotetext{
${ }^{115}$ Essa narrativa mítica pode ser compreendida em maiores detalhes em Ogbebara (2006).
} 
Oxum mandou buscar a galinha d'angola, que até então era toda preta, para pintá-la com pequenas manchas brancas de efun, um espesso pó branco relacionado ao princípio da criação do universo. Em seguida, a divindade modelou um cone ritual (oxu) com diversos componentes mágicos fixando-o sobre a cabeça da ave, dando-a o eterno status de iniciada no culto aos orixás, ou seja, de

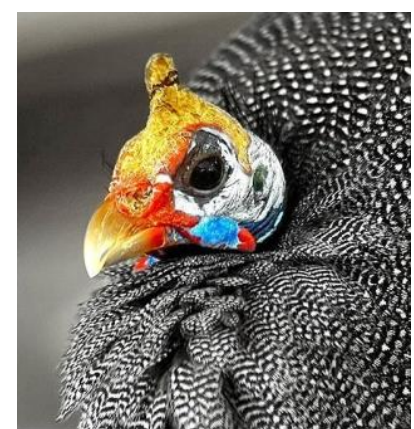

Figura 37: Galinha D'Angola Fonte: Google Imagens ${ }^{\circledR}$ adoxu $^{116}$.

A partir deste evento mítico, a galinha d'angola também conhecida como etu ${ }^{117}$, passou a ser um elemento simbólico fundamental nos ritos iniciáticos do candomblé. Sendo a precursora dos iniciados, por nascer provida de oxи e "pintada" de efun, deve estar presente em todas as cerimônias relativas aos orixás. Por essa razão, todos os neófitos no candomblé recebem um oxu sobre as incisões no alto da cabeça. Na confecção deste símbolo cônico, diversos elementos são utilizados, inclusive partes da própria ave, considerada sagrada pelo povo-desanto.

Como ilustrado no mito supracitado, a galinha d'angola configura-se o "símbolo focal da iniciação ritual no candomblé" (cf. Vogel et al., 2005, p. 18). Isto se observa tanto no uso do animal nas imolações rituais, como na própria estética da primeira performance pública do neófito, através de sua caracterização visual e gestualidade, numa clara alusão à passagem mítica fundante do rito iniciático.

Conforme afirmam Vogel et al. (2005), há inúmeros registros históricos da presença desta ave até mesmo entre os gregos e egípcios, o que reforça através desta longevidade o caráter simbólico de resistência e sobrevivência, que os rituais do candomblé buscam sublinhar. Observando inúmeras características biológicas e comportamentais desta ave, outras simbologias podem ser aferidas e relacionadas à nova identidade do filho-de-santo, tais como: um espírito de comunidade (elas vivem em bandos), uma personalidade combativa e guerreira

\footnotetext{
${ }^{116}$ Adoxu: significa literalmente aquele que possui o oxи no alto da cabeça. Este é o símbolo máximo da iniciação ritual no candomblé, juntamente com a epilação e a escarificação do corpo (catulagem). Daí dizer-se que todo iniciado é raspado, catulado e adoxado.

${ }^{117}$ A galinha d'angola entre o povo-de-santo tem uma profusão de termos correlatos: etu, pintada, conquém, angolinha, tofraco, guiné, galinhola, etc.
} 
(elas perseguem as outras aves obstinadamente), um caráter próspero (elas são prolíficas, põem de 15 a 24 ovos) etc. (cf. Vogel et al., 2005).

Portanto, há um estreito nexo simbólico entre esta ave e a pessoa iniciada. Isto instaura na ritualística da feitura uma relação metafórica e ritual entre os neófitos e a galinha d'angola. Nesta lógica mítica, ambos configuram-se como artefatos. A galinha tendo sido feita pela divindade, e os neófitos feitos a partir do contato profundo com o mana (cf. Mauss, 2003) da própria ave. Assim, a galinha d'angola será um dos elementos mais importantes da lista-de-feitura, além de ser elemento proeminente no mercado dos objetos litúrgicos. A primeira aparição pública do iâ̂ ilustra com clareza a sua condição de figura liminar no ritual, já que seu aspecto geral (vestuário e gestualidade) traduz o misto de gente e animal no qual a feitura lhe converte. Em algumas modalidades de culto, nesta primeira performance do iaô é realizada uma dança bem ritmada que parece repetir os movimentos do ciscar da galinha, onde os braços do iaô abrem e fecham como as asas da ave.

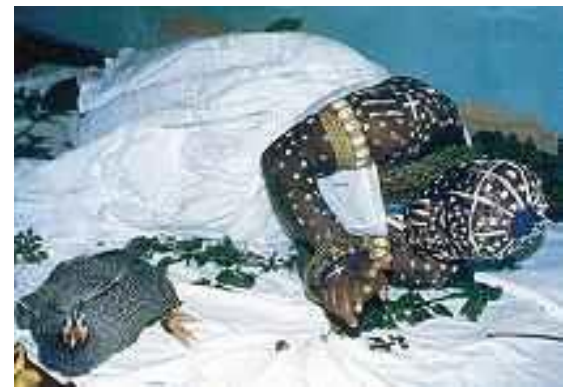

Figura 38: Iâo ao lado da galinha d'Angola

Fonte: Google Imagens ${ }^{\circledR}$

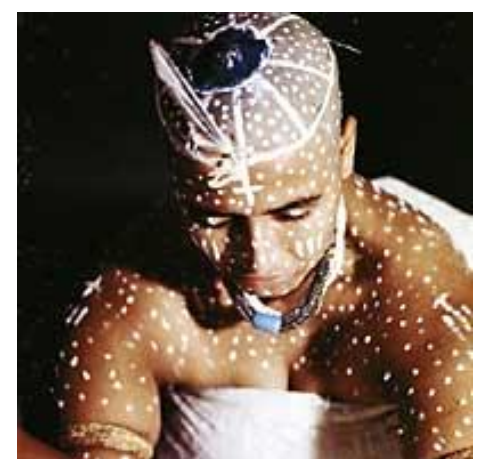

Figura 39: Caracterização ritual da $I a \hat{o}$

Fonte: Google Imagens $®$

Entretanto, façamos um breve esboço da estrutura ritual à qual o abiã será submetido a fim de galgar o próximo estágio na hierarquia religiosa do terreiro. Até o momento do rito de passagem denominado feitura o devoto encontra-se no status de abiã. Somente no decorrer da reclusão ritual, na qual a liminaridade atinge seu paroxismo, o abiã será feito iaô. Sendo que o término desse processo ritual será coroado publicamente com a primeira performance do rum do adeptoorixá. Neste momento, todos os abiãs podem entrar em contato com uma partitura gestual bastante específica, que somente no claustro ritual lhe será efetivamente ensinada através de ensaios. 
Uma vez decidida a data para o início da feitura, o sacerdote irá preparar a lista-de-feitura com todos os elementos litúrgicos necessários para a ritualística. Este ritual é extremamente dispendioso para o abiã. Muitas vezes o abianato é prorrogado justamente devido às limitações financeiras dos adeptos, para conseguirem reunir todo este material. Neste início da carreia religiosa, o abiã irá

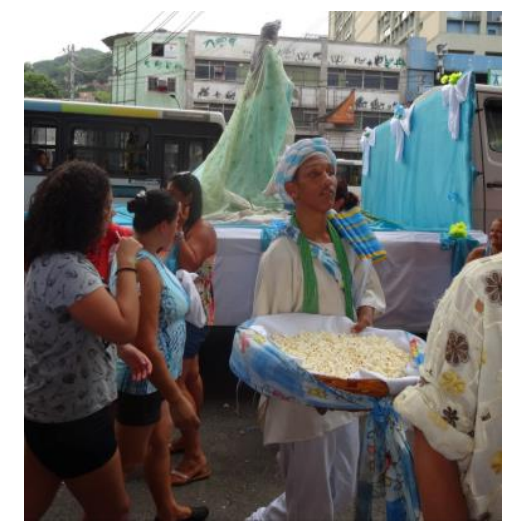

Figura 40: Performance da "esmola" na porta do mercado

Fonte: Acervo da pesquisa compor o chamado enxoval do santo (cf. Silva, 1995, p.128), que inclui um conjunto muito extenso de objetos, comidas, grãos, animais, roupas, insígnias, ervas etc. É muito comum nos terreiros vermos os abiãs pedindo ajuda aos irmãos-de-santo e até mesmo aos visitantes, para conseguirem angariar todo este material. A confecção das vestes rituais também é bastante dispendiosa, por mais singela que seja. Por não possuir nada desse enxoval, esta é uma fase de grande dificuldade.

Ocorrem também alguns casos nos quais o devoto sem recursos econômicos, mas com a real necessidade de realizar a feitura, é recolhido pela chamada misericórdia ou "esmola". Nestes casos extremos, o fiel ou mesmo o sacerdote contam com ajuda até de clientes do terreiro. Pode ocorrer também um ritual no qual os abiãs vão aos espaços públicos da cidade realizando uma performance da "esmola", ou seja, "saem às ruas oferecendo punhados de pipocas curativas de Obaluaiê $\hat{e}^{118}$, em troca de algum dinheiro para a iniciação. Ou ainda, é o próprio orixá que exige que tudo seja feito de "esmola", ensinando assim a humildade a seus filhos" (Amaral, 2002, p. 46).

A lista-de-feitura refere-se apenas aos materiais litúrgicos necessários à realização dos rituais e a montagem dos assentamentos, nos quais o fiel passará a cultuar sua divindade pessoal. Geralmente, esta lista ritual é acompanhada da chamada lista de mercado, na qual estão incluídos alimentos e material de limpeza, para suprir o templo litúrgico no período em que os devotos estarão

\footnotetext{
118 Conforme nota anterior, este é um dos nomes do orixá Omolu. A pipoca (o duburu ou flor de Obaluaiê) é uma das suas comidas rituais prediletas. No imaginário de parte do povo-de-santo, este orixá está profundamente atrelado à ideia de humildade. É notória também a influência do sincretismo com os santos católicos São Lázaro e São Roque. Para maior aprofundamento ver Barros (2005).
} 
auxiliando o sacerdote durante o processo iniciático do abiã. Encontrei também situações em que os sacerdotes faziam as listas, mas davam a opção aos abiãs de entregarem uma quantia em dinheiro ao invés de saírem às compras de cada item.

Contudo, outro prisma pelo qual também poderíamos considerar o abianato como etapa preliminar do rito de iniciático, são justamente as compras litúrgicas realizadas em função desta lista-de-feitura. Na maior parte das vezes, os abiãs ainda não possuem o domínio do vasto léxico ritual que organiza estes materiais, pois são usados em momentos e de maneiras totalmente desconhecidas pelo abiã. Muitos termos são ouvidos pela primeira vez durante o abianato, apenas quando esta lista-de-feitura é entregue ao fiel. Tais listas podem ter muitas páginas, dependendo das competências e escolhas dos sacerdotes. A seguir, apresento como exemplo parte da lista-de-feitura recebida por um dos abiãs que acompanhei nas compras votivas durante a pesquisa:

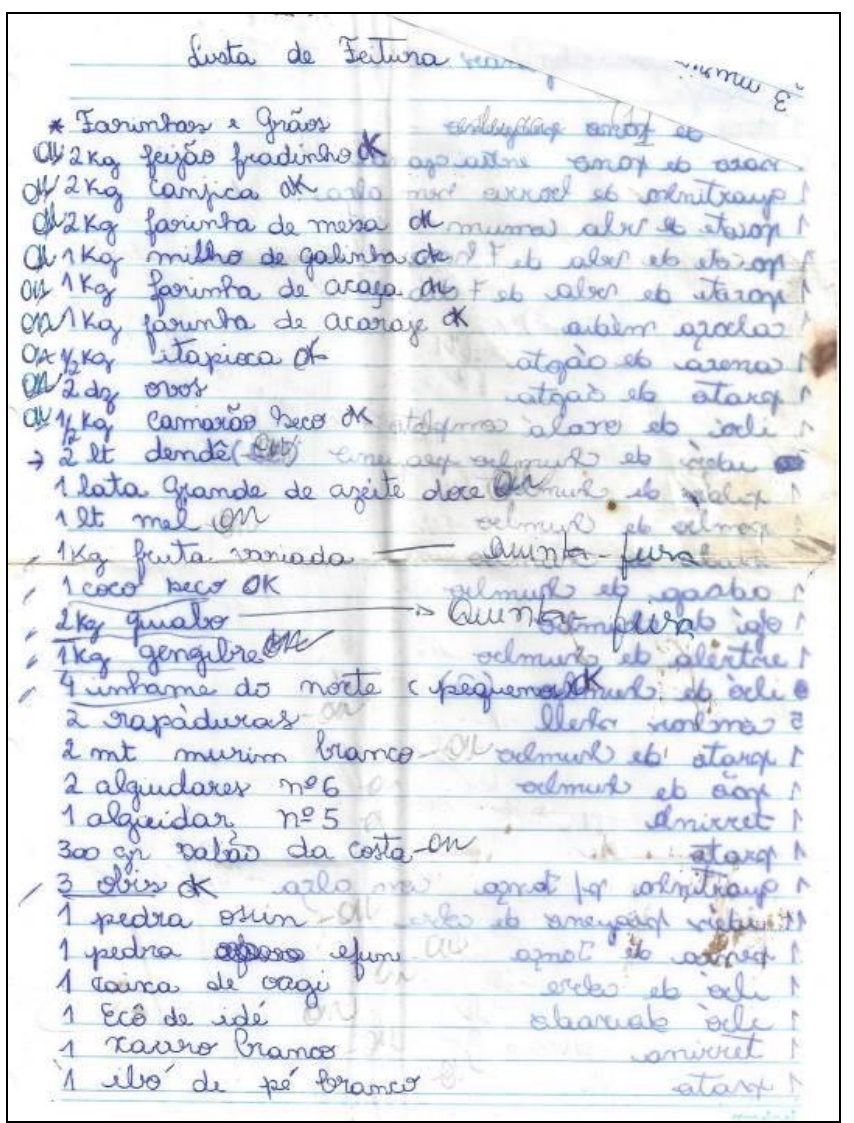

Figura 41: Lista-de-feitura

Fonte: Acervo da pesquisa 


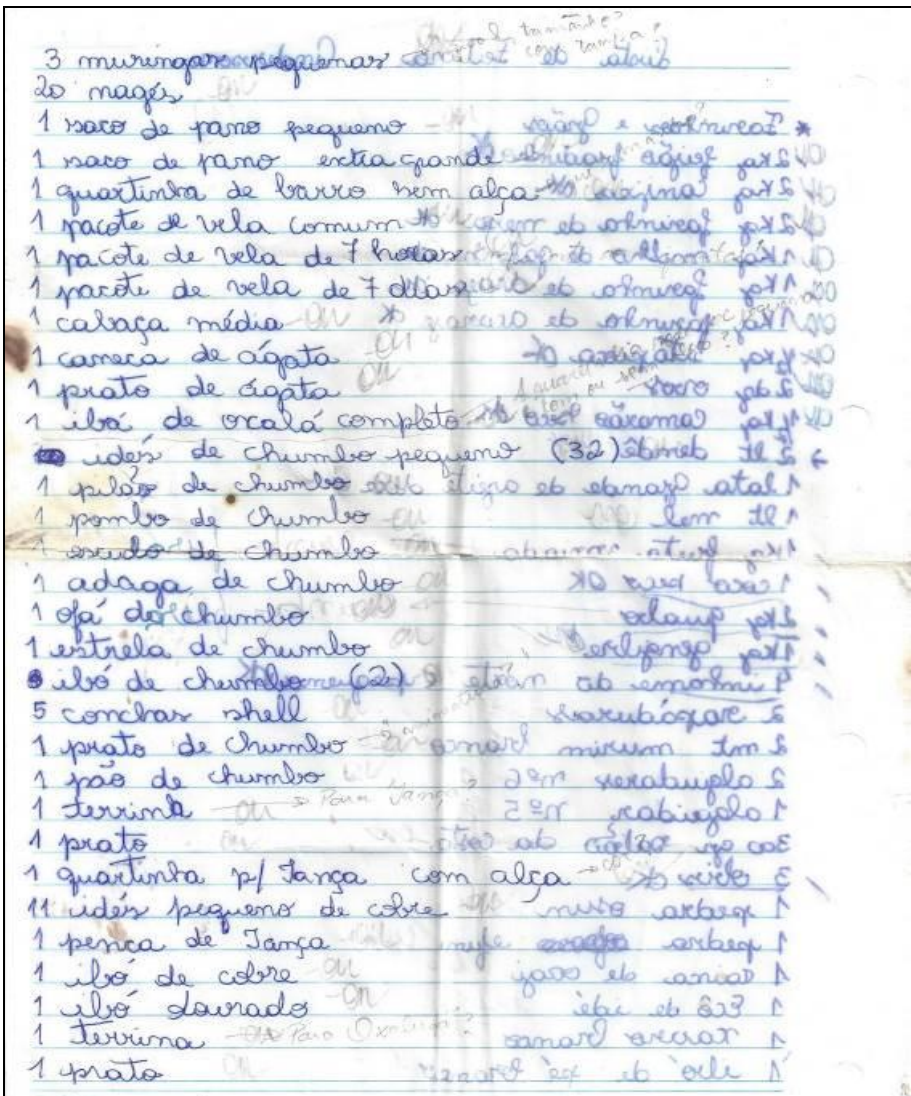

Figura 42: Lista-de-feitura

Fonte: Acervo da pesquisa

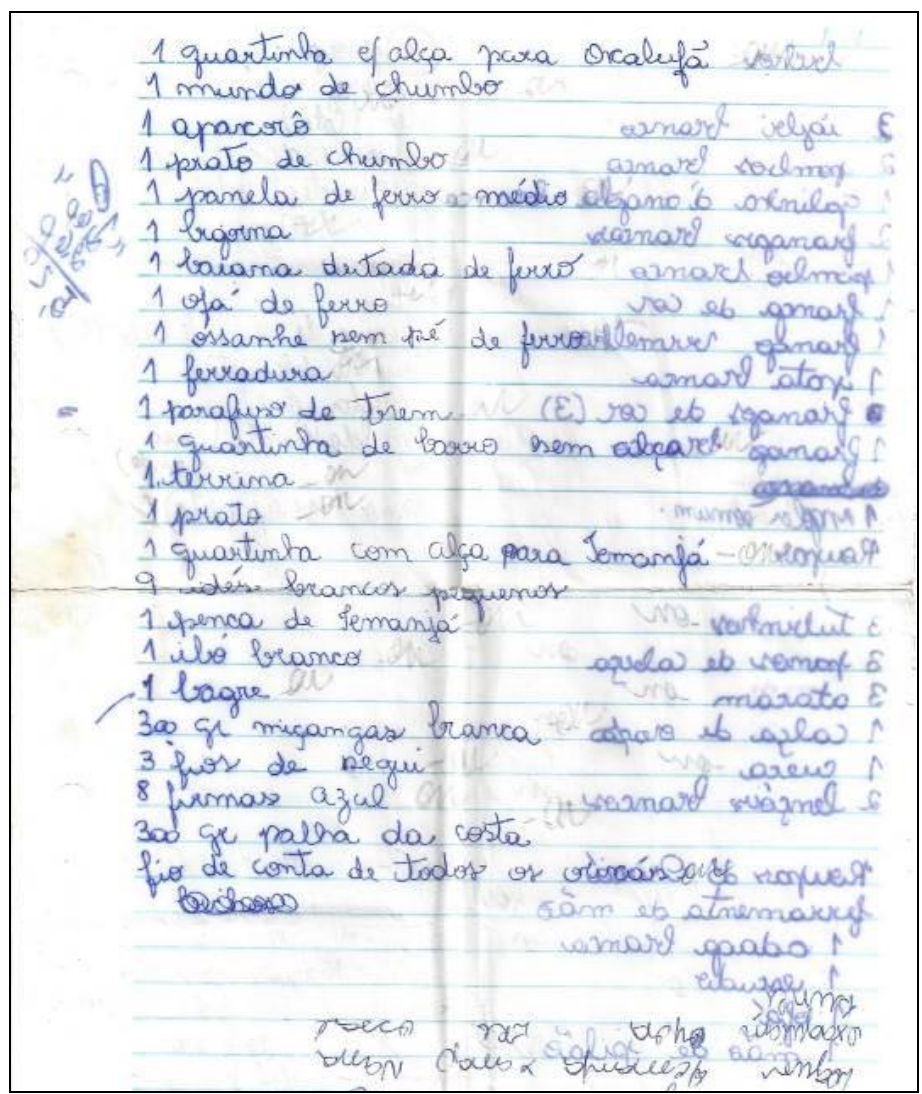

Figura 43: Lista-de-feitura

Fonte: Acervo da pesquisa 


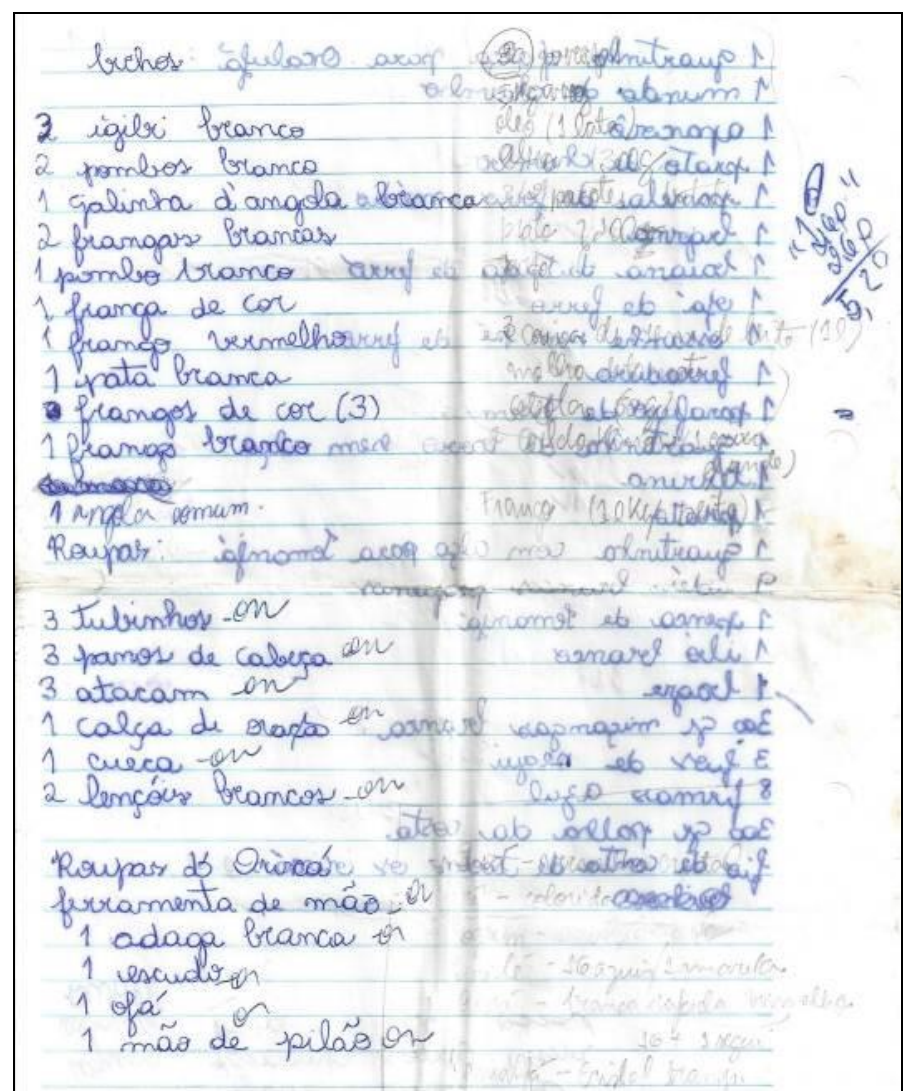

Figura 44: Lista-de-feitura

Fonte: Acervo da pesquisa

Sendo assim, a ida ao mercado especializado para as compras votivas é, ao mesmo tempo, avançar um degrau no processo iniciático, pois introduz o abiã não apenas na língua do santo, mas em suas simbologias rituais. Na maioria dos casos, estes abiãs precisam da ajuda de peritos para decifrarem a complexidade da natureza e do emprego cerimonial dos itens comprados. Esta condição nos faz considerar "a ida ao mercado não só como uma preliminar, mas, propriamente, como o começo da aventura da iniciação, uma etapa que já se encontra sob a égide do rito de passagem" (Vogel et al., 2005, p. 13).

Em alguns terreiros, estas mesmas listas são chamadas de receita, pois que revelam os componentes manipulados na construção ritual da nova pessoa. Para aqueles que dominam os códigos da liturgia, numa simples leitura das listas é possível decifrar detalhes a respeito das divindades que serão assentadas e de como alguns procedimentos rituais se constituem. Como comentam Vogel, Mello e Barros (2005), uma lista-de-feitura "permite estabelecer ou atestar a distribuição social do conhecimento relativo às liturgias afro-brasileiras [e] não só reconhecer um determinado estilo litúrgico [...] como também avaliar a competência de uma prática sacerdotal" (Idem, 2005, p. 13). 
Portanto, a lição oferecida ao abiã ao longo das compras de seu enxoval de feitura é a "descoberta da virtualidade divina contida nas coisas" (Vogel et al., 2005, p.26). Desta maneira percebemos o caráter pedagógico que subjaz na ida às compras litúrgicas para a feitura. Dependendo da personalidade do ebôme que acompanhe o abiã neste momento dos "bastidores" de sua iniciação, o acesso aos sentidos mais recônditos do uso litúrgico daqueles elementos pode ser maior ou menor.

As compras podem ajudar também no estreitamento de laços entre os abiãs e aquelas pessoas que se disponibilizam a ajudá-los, nesse momento que é realmente bastante trabalhoso. Ao mesmo tempo vemos que é um período cansativo e de muita alegria para boa parte dos postulantes. De qualquer forma este aprendizado constrói uma performance do povo-de-santo nos mercados especializados que são também locais de encontro e reconhecimento, em que os abiãs tomam as primeiras aulas que irão se aprimorar ao longo de sua "carreira" religiosa:

Assim, a peregrinação do abiã ao mercado deverá, se ele persistir no culto, repetir-se a cada novo ciclo de obrigações, que marca a sua progressão na carreira iniciática. Por esse motivo, não hesitamos em considerar as compras votivas como parte plenamente integrada a todo e qualquer ciclo ritual do candomblé. [...] A ida do abiã ao mercado é a primeira lição-de-coisas das muitas que vão pontuar a sua vida religiosa. [...] É uma verdadeira aula de candomblé, embora seja apenas a primeira, mas que, como tal, não deixa de ter a expressividade e o impacto das explorações inaugurais de qualquer campo do saber, sobretudo quando se trata de um saber gnóstico. (Vogel et al., 2005, p. 27)

Por diversas vezes vários abiãs vieram até mim perguntando muitas coisas a respeito de suas listas, pois sabiam de minha pertença religiosa. Notei também, que minha identidade de pesquisador soava para eles como sinônimo de uma pessoa mais "liberal" em relação à "tradição" do terreiro. Por ser um iniciado mais velho do culto, mas também um homem acadêmico, eles se sentiam mais à vontade para certos questionamentos. Situação esta que me colocava algumas vezes num certo desconforto no campo. Mesmo assim, em várias circunstâncias, peguei-me sendo o intérprete destas listas rituais, além de acompanhante nas compras votivas.

Passado este primeiro momento preparatório dos "bastidores", inicia-se propriamente a parte privada dos rituais. Por já ter sido bastante explorada pela literatura (Augras, 2008; Bastide, 2001; Verger, 2002; 2012 etc.), retomemos 
apenas alguns aspectos gerais do processo iniciático formal. Como já foi esclarecido, o foco de análise deste estudo está no abianato, que tem sua duração até os primeiros dias do processo de feitura, portanto são as performances do bolar e do "passar mal" que mais nos interessam enquanto experiência de liminaridade do abiã. No entanto, retomemos alguns aspectos da feitura para em seguida nos determos num procedimento específico, que se relaciona diretamente com a construção paulatina da performance do rum.

A feitura consiste num período de reclusão no roncó que pode variar de sete a vinte um dias geralmente. Cada vez mais este período tem variado nas comunidades litúrgicas. Uma vez tendo conseguido todos os materiais necessários para o ritual, o abiã vai com suas malas para o terreiro, onde permanecerá isolado do contato social externo durante todo o ritual. Nos primeiros dias serão executados alguns procedimentos de purificação, que podem ocorrer no barracão e/ou em alguns espaços da natureza.

Todos os pertences do abiã serão conferidos pela pessoa responsável por auxiliar o pai ou a mãe-de-santo no processo. No geral, tal pessoa será a mãecriadeira (jibonã), que ficará em contato direto com o abiã durante o claustro iniciático. Ela será responsável pela alimentação ritual do abiã, pelo seu banho único matinal, pela higienização das suas vestes rituais e também por lhe transmitir uma série de ensinamentos sobre a conduta religiosa. Várias dessas lições de como se comportar segundo a etiqueta religiosa, já foram observadas ao longo do abianato. A convivência no terreiro com outros iniciados possibilita um aprendizado pela observação e pelas experiências partilhadas nas conversas. Neste momento, as normas de comportamento serão apenas repassadas, já que a partir da feitura devem ser cobradas com maior rigor.

Logo de início, serão confeccionadas as insígnias que o abiã receberá no dia do assentamento de seu orixá. Tanto o abiã como outros membros do terreiro participam da confecção dos fios-de-contas ou ilequês (cf. Lody, 2001; Souza, 2007). Isto poderá levar alguns dias, dependendo da disponibilidade dos filhos-desanto. Esses colares rituais são instituídos de valor sagrado marcando com precisão os momentos e as transições na trajetória do adepto religioso. Equivalem a signos que dentro de uma linguagem comum ao povo-de-santo, servem para identificar, durante as festas e os rituais, que posições os atores ocupam no jogo ritual: 
O texto visual do fio-de-contas que é lido, compreendido e estabelecido por artesãos, filhos-de-santo, pais e mães-de-santo, ogãs, equedis, iaôs, abiãs, entre outros, sinaliza a vida religiosa e social dos terreiros, transitando entre códigos tradicionais e outros emergentes e dinâmicos, contudo, mantenedores do próprio ser fio-de-contas. (Lody, 2006, p. 276)

Em algumas modalidades de culto, a próxima etapa consiste na cerimônia do $b o r{ }^{119}$, na qual a cabeça do abiã será louvada e fortificada simbolicamente preparando-o para o momento seguinte da feitura propriamente dita. Todo o corpo está submetido pelo cerimonial, mas é a cabeça que desempenha o papel central. Aqui a reclusão é compreendida "como uma mudança substantiva do corpo" (Viveiros de Castro apud Dos Anjos, 2001, p.137). Nesta etapa, o postulante já estará com seu corpo purificado pelos inúmeros ebós pelos quais passou anteriormente. Uma vez estando "descansado" e com seu orí equilibrado, é chegado o momento de seu entrelaçamento definitivo com o duplo (cf. Dos Anjos, 2001; Augras, 2008).

O clímax do processo ritual de iniciação é o dia em que ocorre o assentamento dos orixás do neófito. Chamado também de orô em alguns terreiros, esta é a etapa culminante de morte e renascimento simbólicos do neófito. É neste ritual extremamente privado que ocorre de fato a conversão de status do abiã para iâ̂, pois é performado um pacto literalmente de sangue entre o devoto e sua divindade.

Sentado no aperê $\hat{e}^{120}$, o abiã terá algumas partes de sua cabeça raspadas por uma navalha ritual. Verifica-se neste ato o sacrifício dos cabelos como um rito de passagem, pois “cortar os cabelos é separar do mundo anterior. Dedicar os cabelos é ligar-se ao mundo sagrado e mais especialmente a uma divindade" (Gennep, 2011, p. 143). Alguns desenhos formados na epilação seguem uma cartilha de estilos rituais de acordo com cada divindade do panteão. Ao longo do processo iniciático esta raspagem será concluída nos dias que seguem. Em todos os resquícios de cabelo, assim como das unhas cortadas "reside uma parte da personalidade" (Idem, 2011, p.144). Para determinadas divindades, todos os pelos do corpo devem ser retirados, inclusive as sobrancelhas. No candomblé, até mesmo nos momentos mais íntimos da ritualística há um cultivo cuidadoso da

\footnotetext{
119 Já me referi a este tema em nota anterior. Ressalto que a literatura descreve essa sequência como fixa, mas presenciei alguns processos no quais o bori não ocorre nesta ordem.

${ }^{120}$ Aperê: espécie de banquinho ou tronco, no qual o fiel senta para a cerimônia da raspagem e catulagem.
} 
dimensão estética.

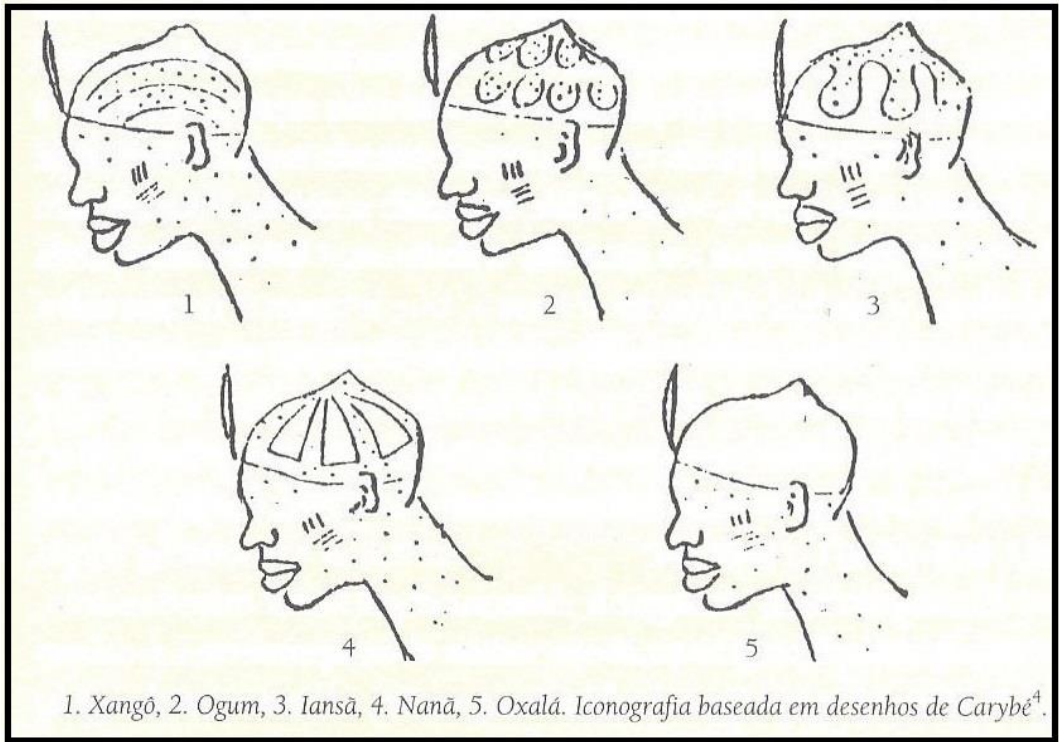

Figura 45: Desenhos rituais da epilação iniciática

Fonte: Lody (2006)

Toda a performance de nascimento e morte é acompanhada por cânticos e rezas. Na sequência, o sacerdote manipulando a navalha ritual abre diversas incisões no corpo do fiel. Estes cortes chamados aberés (gbéré-arâ) ${ }^{121}$ são feitos no topo da cabeça, braços, peito, costas, língua, mãos e pés. Assim como na raspagem dos cabelos, através das escarificações "retira-se o indivíduo mutilado da humanidade comum mediante um rito de separação [...] que automaticamente o agrega a um grupo determinado [...] deixando traços indeléveis, torna a agregação definitiva" (Idem, 2011, p. 76).

Entretanto, o sangue do fiel deve escorrer e misturar-se aos axés que serão colocados sobre todos os cortes. Este é um fluxo duplo de entrada e liberação de axé no corpo do noviço. Neste momento, o fiel já está completamente tomado por seu orixá. Os cantos avançam com a performance. A morte e o renascimento são encenados e ficam registrados eternamente na memória dos que assistem ao ritual, pela emoção e singularidade do ocorrido. Para o povo-de-santo é um dos momentos mais marcantes, pois é o nascimento daquele orixá entre os homens.

\footnotetext{
${ }^{121}$ Gbéré ara, ou mais popularmente curas, representam uma releitura das marcas tribais identitárias dos povos africanos. Tais escarificações, segundo a exegese nativa, possuem duplo simbolismo. Assim como abrem o corpo para despertar o Ėsù (princípio dinâmico que propicia a nova existência), servem também como proteção espiritual ao neófito. Sobre as incisões será colocado o um pó ritual (atin gbéré). Há concomitantemente uma ingestão do atin gbéré para proteção interna do corpo.
} 


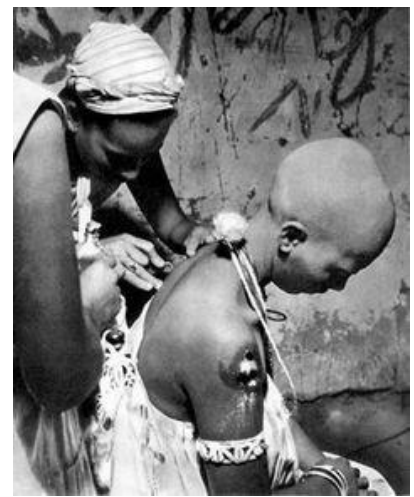

Figura 46: Escarificação ritual na feitura

Fonte: Medeiros (2009, p. 38)

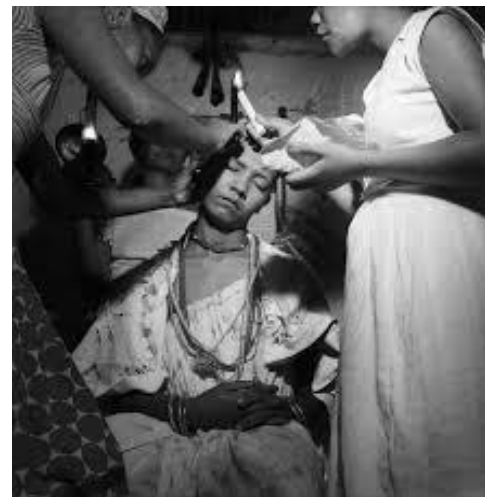

Figura 47: Epilação ritual na feitura

Fonte: Medeiros (2009, p. 39)

Seguindo o sacrifício do próprio abiã no aperê, alguns animais serão imolados. A galinha d'angola deve estar presente rememorando o mito fundante do próprio culto. Um fluxo de sangue $(e j e ̂)^{122}$ deverá verter sobre o orí aberto do abiã. Nesses fugazes segundos, o sangue da imolação irá se unir ao sangue do próprio devoto, escorrendo sobre a pedra (ocutá) que eternamente simbolizará uma aliança entre as duas dimensões da existência (orun e aiê). Sob este jorro de sangue vivificador materializa-se a virtualidade do orixá em pedra e carne. A quentura e o cheiro do sangue entram pelos orifícios do fiel rememorando sua chegada ao mundo pela primeira vez. É parido pelas mãos do sacerdote o recémnascido adepto-orixá. Dos Anjos (2001) no estudo dos rituais do batuque descreve a intensidade simbólica do evento:

O fluxo de sangue que escorre sobre a cabeça do iniciado e se derrama sobre a bacia que contém os ocutás é recebido por um sentimento muito próximo do ato de dar à luz, o que absolutamente nada tem a ver com crueldade. [...] $\mathrm{O}$ iniciado encharcado de sangue é uma figura ambígua: por um lado está nascendo fortalecido pelo orixá, por outro está dando à luz a seu orixá pessoal, aquele de quem ele passará a cuidar. Simultaneamente pai e filho, a iniciação é fundamentalmente desdobramento do mesmo no seu duplo - o outro. [...] O sagrado se personalizou na pessoa como um outro que se manifesta e requer cuidados. (Dos Anjos, 2001, p. 146-147)

Ao término dessa sequência, o orixá passará a existir de forma individualizada no corpo do neófito, onde depois de nascer será materializado e alimentado diversas vezes ao longo da "carreira" religiosa do fiel. Está selado um compromisso do neófito com sua divindade, com as pessoas envolvidas na

\footnotetext{
${ }^{122} \mathrm{O}$ termo utilizado para indicar este ato é sundidé (acordar ou levantar do sono), ou seja, um banho ritual do sangue dos animais imolados. Representa a transferência da vida dos animais para os objetos sagrados e o ori estabelecendo um elo entre os três.
} 
performance da feitura e a comunidade litúrgica como um todo. A partir dessa etapa ritual a cabeça tornou-se a morada do orixá, que deverá ser cuidado pelo neófito, porque "a cabeça é o centro, é o polo fundador e irradiador da iniciação, onde se carrega o santo, pois este mora na cabeça. A cabeça é o orixá, e o orixá é a cabeça" (Lody, 2006, p. 84).

Só então, os novos fios-de-contas que estavam submersos no sumo das ervas, são colocados no corpo do iaô como emblemas no novo status. Além de outros símbolos como: o mocã, a umbigueira e os contra-eguns (tranças de palha que protegem das más influências, colocadas respectivamente no pescoço, na cintura e nos braços); o xaorô (guizos atados ao tornozelo) ; o quelê (espécie de gargantilha que destaca a sacralização da cabeça) e o delogum ou ilequês (colar de vários fios com as contas do orixá protetor do devoto). Todos estes elementos da nova veste ritual caracterizam pacto com a divindade, obediência e subordinação. O colar ritual chamado quelê enseja também o vínculo de subordinação eterna do sujeito ao sacerdote responsável pela sua feitura:

No começo da iniciação, a noviça recebe um colar, kelê, que expressa sua sujeição absoluta à sacerdotisa que a está iniciando. Diz-se na verdade, "à mãe de santo que a fez". Trata-se realmente de uma recriação do indivíduo, efetuada em termos místicos. Do mesmo modo, chamam-se todas as sacerdotisas pelo nome genérico de "feitas". Pelos ritos, elas foram "feitas", refeitas, recriadas como servas dos deuses, depositárias e transmissoras do axé. (Augras, 2008, p. 87)

Nesta metamorfose ritual, o fiel terá partes do seu corpo pintadas com alguns pigmentos carregados de simbologia como, o efun (o branco: poder da criação), o waji (o azul: poder de transformação e agitação) e o ossum (o vermelho: poder da realeza e fertilidade). Vemos neste ato ritual a importância das pinturas corporais, "que marcam uma diferenciação temporária. São estas que vêm desempenhar considerável papel nos ritos de passagem porque se repetem a cada mudança na vida do indivíduo" (Gennep, 2011, p. 78). Como veremos depois, esta pintura será repetida várias vezes até o final do processo da feitura.

Na sequência, o neófito recebe no alto da testa a pena de ecodidé presa por uma fina trança de palha, que simboliza a chegada das riquezas e da realeza à sua cabeça. Por ser a pena de um papagaio africano, está associada também a capacidade da fala dada ao novo ser. E, por último, o símbolo máximo da iniciação: o oxu. De acordo com a narrativa mítica fundante, este emblema constitui o marco simbólico da feitura do iniciado. 


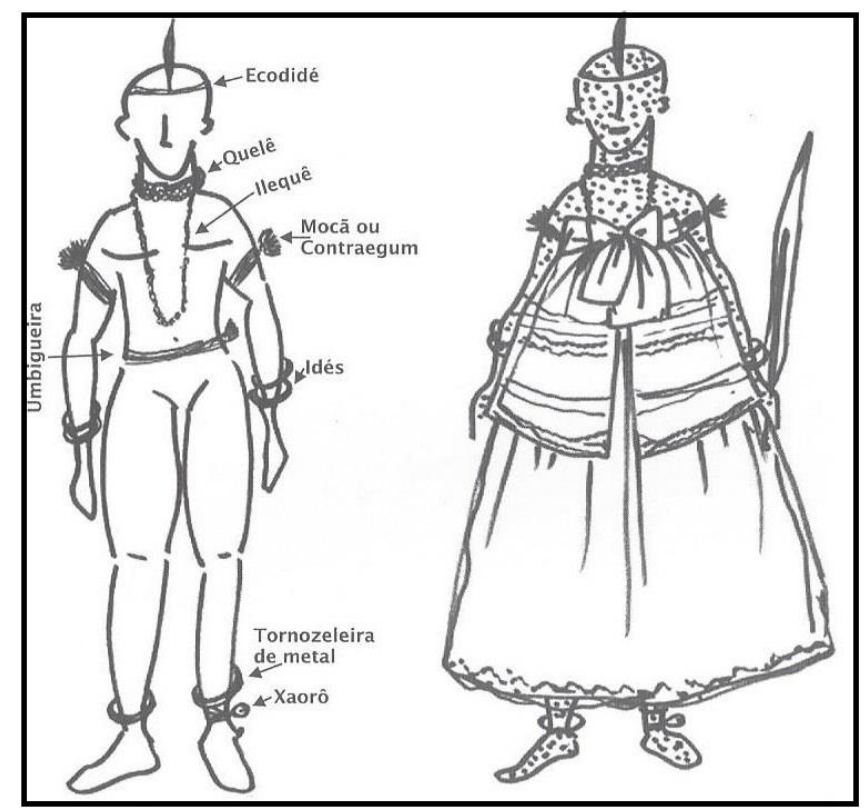

Figura 48: Iâ̂ e os emblemas do novo status

Fonte: Sabino \& Lody (2011, p. 83)

Enquanto isso, seguem-se os aprendizados da etiqueta hierárquica e da ritualística. A relação de subordinação é cada vez mais reforçada. Neste estado de integração intensificada ao novo ethos, "os iniciados fingem não saber andar nem comer, etc., em resumo procedem como recém-nascidos (ressuscitados) e reaprendem todos os gestos da vida comum" (Idem, 2011, p. 83). Como enfatiza Schechner "a ação por trás da iniciação é performativa" (Schechner, 2011, p. 164). Com isso o neófito passará os dias deitado sobre a esteira e alimentando-se apenas de comida ritual, além de alguns momentos de jejum. Nesta fase, a relação com o chão é bastante intensificada, pois ele é um elemento fundamental na constituição dos laços na comunidade litúrgica:

[...] estar no chã é também ser situado na base de uma hierarquia - posição que reconhecemos como "abaixo" em relação a coisas que aprendemos a abordar de uma perspectiva vertical e em movimento. É dessa posição que vemos a mãe-desanto e os outros filhos da casa que podem sentar em cadeiras, levantar e moverse à vontade e que vêm nos visitar, banhar, alimentar, nos iluminar com histórias e lições práticas ou simplesmente vigiar nosso comportamento. O chão nos define como seres a quem eles devem instruir e dispensar cuidados. E, frente a eles, nos dispõe a docilidade e a obediência. [...] É o chão que oferece a perspectiva pela qual se orienta no espaço e se dirige aos outros. (Rabelo, 2014, p. 259)

A partir disso, o novo iâ̂ será mantido recluso no roncó até o dia da cerimônia de apresentação pública denominada saída de iaô. É nesta festividade que ele viverá pela primeira vez diante do público a sua performance do rum. Neste acontecimento que coroa a feitura, os membros do terreiro e o próprio 
devoto depositam grandes expectativas, e para isso empenham-se no treinamento desta apresentação. Afinal, será a primeira vez que o novo filho-de-santo desempenhará a dança solo de seu orixá.

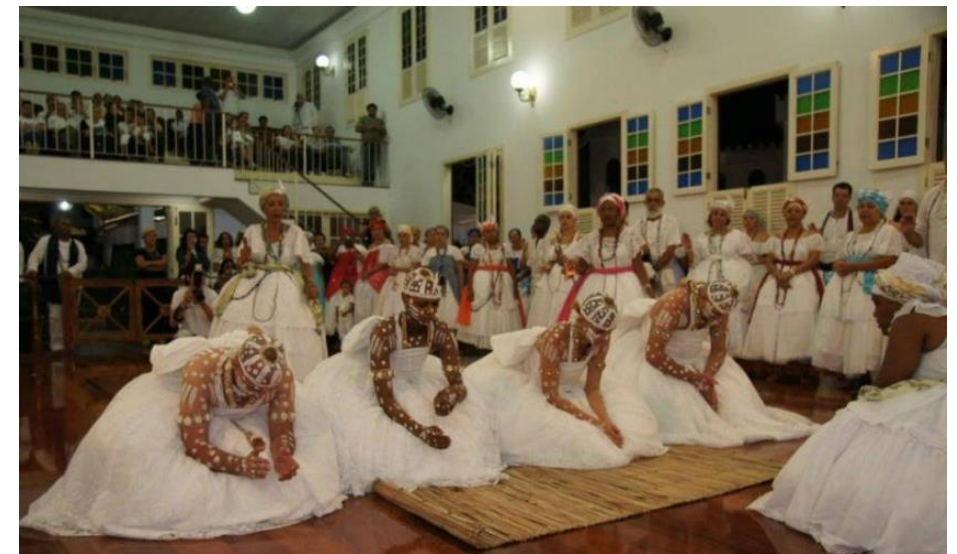

Figura 49: Performance da saída de um barco de iaôs

Fonte: Google Imagens ${ }^{\circledR}$

A festa da saída do iâo, também conhecida por dia do nome (orucó) - no qual o neófito é renomeado ritualmente - expõe em sua realização grande "teatralidade", pois constitui-se de um gestual bastante coreografado e ampliado. Isto sem falar na pronunciada condição estética do iâ̂. Nesta performance ritual, há uma partitura corporal bem demarcada segundo uma "tradição" perpetuada pelo grupo. A ideia de "tradição" surge, pois as performances, cotidianas ou não, apresentam na maior parte dos casos, mais de um autor. Como explica Schechner, "rituais, jogos e performances da vida diária são escritas por um ente coletivo Anônimo ou pela Tradição. Pessoas a quem se credita a criação de um jogo ou rito, geralmente, revelam ser sintetizadores, recombinadores, compiladores ou editores de ações já praticadas anteriormente" (Schechner, 2003, p. 34). Esses modelos de comportamento precisam ser aprendidos e treinados anteriormente à festa, pois "o comportamento em performance não é livre e fácil [e, portanto] nunca 'pertence' completamente ao performer" (Schechner, 2011, p.156).

Embora o abiã já tenha observado em outras circunstâncias a execução desta performance durante alguma saída de iâ̂, é somente nos "bastidores" de sua própria feitura que ele terá a oportunidade de aprendê-la na prática. Ou seja, de performá-la no próprio corpo através de um processo de restauração desses modos convencionados de comportamento ritual. Todas as ações que serão realizadas no evento da saída do iâ̂ constituem esta restauração de 
comportamento, porque "todo comportamento é comportamento restaurado - todo comportamento consiste em recombinações de pedaços de comportamento previamente exercidos" (Schechner, 2003, p. 34). O comportamento dos religiosos no dia do nome estará "marcado", "emoldurado" ou "acentuado" numa separação do simples viver (cf. Schechner, 2003, p. 34).

Por conseguinte, nos dias que antecedem sua primeira performance do rum, em alguns momentos específicos do claustro ritual, o neófito será retirado do roncó para a realização de um ritual chamado por alguns adeptos de perfuré (cf. Opipari, 2009), ou simplesmente, ritual do efun ${ }^{123}$. Em algumas circunstâncias, os próprios adeptos utilizam a expressão ensaio do iâิ, o que nos leva a perceber que em algum nível eles mesmos apreendem a dimensão "teatral" da realidade vivida no terreiro. Nesta ocasião, o devoto é submetido novamente às pinturas corporais e em seguida são realizados ensaios da performance que ele deverá apresentar no dia do nome:

O período de reclusão, durante o qual a aliança entre o neófito e seu santo será selada, é igualmente pontuado pelo aprendizado de cantos, rezas, passos de dança, regras do protocolo ritual etc. Após a raspagem da cabeça, a "feitura" propriamente dita, os iaôs que entram em transe (rodantes) realizarão durante três dias o ritual do perfuré. [...] O desenrolar do perfuré, como um ensaio geral de teatro, segue de muito perto o protocolo da festa de apresentação pública do novo iniciado. [...] Ao longo dos três dias de perfuré, uma atenção é especialmente dada a cada gesto, a cada postura do iaô, pois é pelas variações destes que serão identificadas as modulações do transe que culminam na efetiva presença do santo em seu corpo. (Opipari, 2009, p. 227-228)

Portanto, considerando a performance no sentido processual proposto por Schechner $(1988 ; 2003 ; 2011 ; 2012 \mathrm{a} ; 2012 \mathrm{~b})$, este procedimento nos revela o vínculo profundo entre as performances ritual e estético teatral. Com esta concepção a respeito da performance, Schechner reforça "a sua posição contrária à dicotomia entre dramas rituais (ou sociais) e dramas estético-teatrais, conforme sugerido por Turner em seu modelo de estudo antropológico da performance" (Silva, 2005a, p. 56). Neste procedimento do processo iniciático da feitura fica claro o continuum apregoado por Schechner (2003) entre o ritual e o teatro:

\footnotetext{
${ }^{123}$ A expressão ritual do efun (ou saída do efun) recebe este nome pelo fato do iaô ser pintado com uma pasta feita da pedra de efun. Trata-se de um elemento calcário de grande valor cerimonial, pois está associado ao poder de criação dos orixás primordiais da cosmologia Jeje-Nagô. Este ritual apresenta variação entre os terreiros. Pode ser feito em quatro ou sete dias durante a reclusão ritual do neófito. $\mathrm{O}$ iaô é pintado com todos os pigmentos e levado ao salão para ensaiar sua primeira aparição pública. Ao longo deste rito, espera-se que o devoto esteja em estado de orixá.
} 
Performances artísticas, rituais ou cotidianas - são todas feitas de comportamentos duplamente exercidos, comportamentos restaurados, ações performadas que as pessoas treinam para desempenhar, que têm que repetir e ensaiar. [...] Toda ação, não importa quão pequena ou açambarcadora, consiste em comportamentos duplamente exercidos. (Schechner, 2003, p. 27)

Conforme observa Silva (2005a, 2012) a abordagem de Schechner tem em perspectiva as três fases invariantes dos ritos de passagem sugeridas por Van Gennep, ou seja, separação, transição e incorporação (ou reintegração). O que pode ser representado também num outro esquema fásico: fase preliminar, liminar e pós-liminar. Na proposta de Schechner, a sequência total da performance é examinada e dividida em sete fases distintas, a saber: treinamento, oficinas, ensaios, aquecimentos, performance propriamente dita, esfriamento e desdobramento. Sendo assim, estas sete etapas podem ser rearranjadas dentro da perspectiva proposta por Van Gennep, de tal forma que: treinamentos, oficinas, ensaios e aquecimento, corresponderiam à fase preliminar dos ritos de separação; a performance propriamente dita evidencia a fase liminar dos ritos de transição; enquanto que esfriamento e desdobramento configuram a etapa pós-liminar dos ritos de reintegração.

Seguindo este prisma de análise da performance, é no momento do ritual do perfuré que o performer iâ̂ adquire grande dos "pedaços de comportamento restaurado" (cf. Schechner, 2003, p. 28) que irão dar origem a sua performance do rum na saída do nome. Desta maneira, "o que já foi experimentado, ensaiado durante o perfuré, aparece [...] quando o iaô é levado a manifestar explicitamente a figuração do santo em seu transe" (Opipari, 2009, p. 230). O perfuré configurase como um dos vários momentos exemplares da pedagogia litúrgica no cotidiano do terreiro:

Experimenta-se na pedagogia do sagrado, que é formalizada na iniciação do iaô noviço -, um amplo e complexo aprendizado para diferentes temas, destacandose o ensino das coreografias. Isso acontece em rituais privados chamados de ensaio ou ensaio de iaô, momento em que as posturas corporais e linguagens da revelação do corpo situam o recém-iniciado como conhecedor das danças dos orixás. (Sabino \& Lody, 2011, p. 55)

Nos seus estudos em que relacionou teatro e ritual, Schechner (1988; 2003; 2011; 2012a) sugeriu duas tipologias de performance: a transportadora (transportation) e a transformadora (transformation). Porém, não deixou de destacar que em diversas situações, ambas as categorias estão bastante imbricadas. 
Para exemplificar sua tese, ele cita o trabalho do ator, no qual à princípio o desaquecimento traz o performer de volta para a esfera habitual da existência, que foi seu ponto de partida. Todavia, há circunstâncias em que o ator interpreta papeis que lhe provocam efeitos de transformação, da mesma forma como ocorre nos ritos de iniciação. O próprio autor esclarece:

I call performance where performers are changed "transformations" and those where performers are returned to their starting places "transportations""transportations", because during the performance the performers are "taken somewhere" but at the and , often assisted by others, they are "cooled down" and reenter ordinay life just about where they went in. The performer goes from the "ordinary world" to the "performative world", from one time/space reference to another, from one personality to one or more others. (Schechner apud Silva, 2012, p. 58)

Devido a este processo, atores interpretam personagens e religiosos entram em transe, e nesta transformação são capazes de realizar ações em performance que jamais executariam na vida ordinária. Neste contexto, o autor identifica os ritos de iniciação na categoria das performances de transformação, justamente por objetivarem a transformar o status ou as identidades das pessoas. Neste quesito, Schechner ainda salienta que este transporte pode ser voluntário ou involuntário. A interpretação de um papel por um ator está na primeira categoria, enquanto que o transe estaria na segunda. No entanto, ambas as situações apresentam profundas semelhanças estruturais, inclusive no tocante à "mútua possessão do atuador e do papel atuado" (cf. Carlson, 2011, p. 182):

$\mathrm{O}$ ator que interpreta um personagem envolvido no fluxo da performance não é ele mesmo, mas, ao mesmo tempo, ele não é e nem deixa de ser ele mesmo. Os performers em transe também são frequentemente conscientes de suas ações até quando estão em performance; e eles também se preparam através de treino e aquecimento. A diferença entre esses tipos de performances pode estar mais na rotulagem, na classificação e nas expectativas culturais do que em seus processos de performance. (Schechner, 2011, p.164)

Por este prisma, quando em performance, o performer está vivendo o ápice da liminaridade, que constitui um verdadeiro limen. Assim, "em performances rituais e estéticas, o espaço sutil do limen é expandido [...] O que, normalmente é apenas um 'estar entre', torna-se local da ação" (Schechner, 2012a). Uma ação que nos remete ao que Turner (2005) classificou como betwixt and between. Com essa especificidade, "ela é ampliada no tempo e no espaço e ainda mantém a sua qualidade peculiar de passagem ou temporalidade" (Schechner, 2012a, p. 64). Por esta razão, que Schechner (2012 a) nos alertou para o duplo papel da liminaridade, 
por um lado de possibilitar a internalização de novas identidades e novos poderes, e por outro de reduzir os performers a uma vulnerabilidade necessária para as mudanças.

Observando a vulnerabilidade e os riscos da liminaridade do transe marcada pela falta de controle, que necessita de ajuda para "voltar" compreendemos a importante participação dos co-performers no ritual do perfuré e de todas as performances do rum no candomblé. O pai-de-santo, os ebômes e a mãe-criadeira que ensaiam o iaô no perfuré, são somente transportados, enquanto que os neófitos são transformados. Ao término dos ensaios do iaô no perfuré ou de sua performance do rum, os já iniciados retornam à vida cotidiana aproximadamente no ponto em que a deixaram:

Quando a performance acaba, os transportados retornam para as suas vidas no mesmo ponto em que as deixaram e os transformados sofrem mudanças. [...] O que o transportado imprime no transformado no ponto de contato, é para ficar [...] Ou alguma coisa é extraída dos transformados [...] Essas marcas, adições e subtrações, não são simplesmente flechas apontando para um significado mais profundo. Elas estão cheias de poder: elas conectam uma pessoa com a sua comunidade, ancorando-a a uma identidade social; elas são ao mesmo tempo íntimas e públicas. (Schechner, 2011, p. 166-167)

Durante o perfuré, o sacerdote e os demais ebômes que o auxiliam transmitem ao neófito as partituras corporais que serão executadas por ele no dia da sua primeira aparição pública. Tanto os ritmos das cantigas, quanto os gestos que os acompanham são transmitidos ao iâ através da exemplificação dos iniciados. Observação e mimese operam juntas nessa fase preliminar da performance do rum. Estes ensaios ocorrem num momento bastante reservado do processo iniciático. Somente os iniciados devem presenciar esta etapa preliminar da performance ritual da saída do iâ̂.

No decorrer do abianato, ao menos nos terreiros que acompanhei os abiãs não podem presenciar este treinamento, que encaramos aqui como uma fase de restauração de comportamento. Mas podem assistir às performances de saída de iâ̂ de outras fiéis, o que lhes proporciona a acumulação de pedaços de comportamento na memória. Este material será obviamente restaurado durante a vivência da feitura. Por isso, não deveríamos julgar o abianato como completamente apartado do ritual de feitura. O desempenho do iâ̂ na performance do rum é resultado não apenas do que ele aprendeu no perfuré mas, sobretudo, dos pedaços de comportamento que acumulou pela observação durante 
a experiência do abianato. Lembremos que em vários casos as pessoas permanecem anos como abiãs e, portanto, pela perspectiva processual da performance, seus recorrentes contatos com as performances de seus pares seriam ricas oportunidades de restauração de comportamento.

Todavia, não podemos perder de vista que, para os religiosos, este treinamento tem o caráter de ritual, por mais que seu desenrolar enfatize a dimensão técnica da performance. Este momento delicado e exaustivo da feitura gera bastante ansiedade em todos, pois embora seja um ritual, nesta etapa há uma grande preocupação com aspectos relacionados às habilidades artísticas do neófito, como o ritmo, a coordenação motora, a plasticidade dos gestos etc. $\mathrm{O}$ próprio sistema psicológico do iaô é bastante afetado, pois depois de longo tempo sendo um coadjuvante no xirê durante o abianato, ele passa abruptamente em poucos dias a ocupar o papel principal ao rufar dos atabaques, para que ele viva sua primeira de muitas performances de rum. É somente neste episódio que se poderá aferir sua real desenvoltura para a performance do rum, apresentando o que entre o povo-de-santo se chama pé de pincel ${ }^{124}$.

Enfim, o abiã precisará passar por todas estas atividades dos "bastidores" até que esteja autorizado e legitimado a realizar a sua performance do rum após a feitura. Desta forma, todas as vivências até esse momento foram processualmente construindo sua identidade de filho-de-santo, e consequentemente suas performances de estado de orixá.

Na próxima sessão, observaremos os mesmos mecanismos intrínsecos da performance do rum na performance do bolar dos abiãs. O que nos leva a deduzir com mais convicção o continuum ritual entre o abianato e a feitura.

\footnotetext{
${ }^{124}$ Pé de pincel (ou pé de dança, pé de ouro, pé lavado): expressões usadas no candomblé para designar aqueles iniciados que apresentam grande habilidade para as danças rituais. Como explicam Sabino \& Lody (2011), a estética ritualizada do orixá é consagrada pela habilidade e a performance do bem dançar do filho-de-santo, "atribuindo-se o conceito do pé, pé de dança, que significa capacidade corporal e conhecimento detalhado de cada coreografia" (Idem, 2011, p. 55)
} 


\title{
4.3.2
}

\section{Abiã vira ano santo? - A performance do bolar ou "passar mal"}

No candomblé, a expressão do numinoso revela-se justamente através do transe de orixá ou estado de santo. Afinal, todos que estão nesta modalidade religiosa parecem motivados por este contato tão próximo com a dimensão sagrada da existência. Nas performances do estado de santo o sagrado é materializado e alcançado, seja no próprio corpo do fiel, no caso dos rodantes, ou para os não rodantes, no corpo de seus pares envolvidos no transe. É esta experiência da presença do orixá possibilitada pelo corpo do filho-de-santo, que justifica todas as práticas litúrgicas ensejadas pela crença na existência das divindades e a possibilidade de interlocução direta com elas. Portanto, é no momento das performances do xirê, que o fiel tem a sua tão esperada oportunidade de estar frente a frente com os orixás, de transportar-se para esta outra dimensão da própria existência, conforme aprendem logo cedo os abiãs:

\begin{abstract}
Ah, o orixá acho que é uma energia avassaladora nas nossas vidas. Até no nosso corpo. Naquele transe que a gente fica. É a força que rege a natureza. [...] A gente faz as danças pros santos. É uma invocação. A gente dança comemorando. A gente dança com o orixá também. (abiã Priscila)
\end{abstract}

Ah, é uma luz! Parece que a pessoa renasce. Se percebe. Eu acho que o orixá ilumina mesmo. Literalmente falando, a pessoa fica mais bonita. E aquilo sai de dentro e reflete mesmo. [...] Ali é outro mundo. Quando você entra num barracão, ali é outro mundo. (abiã Jurema)

O corpo da gente é o templo do orixá! Onde ele vai passar. [...] (abiã Odete)

O corpo? O orixá usa como domínio das ações dele, né? Porque se não tiver o corpo como o orixá vai se identificar, né? [...] (abiã Janete)

Os discursos dos abiãs nos mostram o quanto este momento das performances do transe de orixá encerra tanto a certeza da presença do numinoso entre os homens, como também possibilitam o prazer da celebração da vida. Ou seja, são nessas performances que as duas esferas da realidade (orun e aiê) se reintegram, conforme a visão dos fiéis do candomblé. Neste momento paroxístico da religião, estão reunidos a eficácia da crença no ritual e o enorme prazer da experiência festiva que o constitui. Como aponta Schechner (2003, 2011, 2012a), a eficácia e o entretenimento, apresentam-se como polos ligados por uma ação 
contínua, visto que nenhuma performance é eficácia ou entretenimento puros:

Se alguém vai chamar uma performance específica de "ritual" ou "teatro", isso depende em grande parte do contexto e função. Uma performance é chamada de um ou outro por causa do lugar onde ela é performada, por quem, em que circunstâncias e com que propósito. O propósito é o fator mais importante para determinar se uma apresentação é ritual ou não. [...] A performance não se origina em um ritual mais do que se origina em um dos gêneros estéticos. A performance se origina nas tensões criativas do jogo binário: eficácia entretenimento. [...] Eficácia e entretenimento não são opostos, mas "parceiros de dança", cada um dependendo contínua e ativamente da relação com o outro. (Schechner, 2012 a, p.81-82)

Schechner (2003) listou as sete funções que a performance pode exercer nas diversas culturas, a saber: "entreter; fazer alguma coisa que é bela; marcar ou mudar a identidade; fazer ou estimular uma comunidade; curar; ensinar, persuadir ou convencer e lidar com o sagrado e com o demoníaco" (Idem, 2003, p. 45). No entanto, o autor destaca que estas funções não estão em ordem de importância, e nem mesmo toda performance exerce todas elas, embora muitas das performances enfatizem mais de uma.

Baseado nisso, talvez pudéssemos compreender porque participar das performance do xirê influencie significativamente o ingresso de tantos visitantes na religião, como pôde ser percebido nos discursos dos abiãs neste estudo. Na maior parte dos casos, foi a festa litúrgica o primeiro contato que tiveram com esta modalidade religiosa. É no momento da performance do xirê que misturam-se as divindades e os homens, pois as fronteiras são rompidas na explosão do transe, que é experienciado pelos presentes em meio a uma intensa fruição estética. Relacionado a isso, há no candomblé a expressão ará layó, ou seja, o corpo da alegria (cf. Sabino \& Lody, 2011).

Contudo, estar presente no xirê é extremamente significo para os abiãs. Como vimos anteriormente nas duas cenas descritas na abertura desta sessão, a participação dos abiãs Afonsinho e Vanise num dia de xirê, foi profundamente determinante em suas trajetórias religiosas, mesmo que de maneiras díspares. No caso de Vanise, sua sacerdotisa conversou com o orixá estabelecendo uma espécie de trato para que pudessem realizar a feitura. Segundo Vanise me relatou:

A última vez pra mim não foi tranquila, porque foi decretado que de fato eu ia tê que "recolhê". [...] A mãe Dora veio conversar com ele [o orixá]. Ela perguntou se ele aceitava um bori e ele disse que não. Aí ela conversou com ele: "o senhor tem que ajudar! Recolhê eu recolho, agora eu preciso de ajuda. Tem a questão da filha dela, do esposo dela. Ele tem que vir aqui pra me dizer que ele aceita". E ele 
foi! Realmente o orixá te prova! Ele me provou ali que ele queria que eu fosse iniciada na religião. Não tem como duvidar! (abiã Vanise)

Depois desse evento, a abiã ficou ainda mais confiante, pois segundo ela, o orixá cumpriu o prometido, e por isso, ela aceitou marcar a data de sua feitura. Esta situação, do ponto de vista dos religiosos, legitima ainda mais a experiência do transe de orixá. E do ponto de vista de nossa análise, vemos o quanto esta performance do bolar ou "passar mal" possui grande relevância ritual, na biografia religiosa do fiel.

Por outro lado, temos o episódio de Afonsinho, onde o pronunciado valor da performance do bolar ou "passar mal" revela-se pela sua não ocorrência. Sendo contrariado pelo avô-de-santo impedindo-o de bolar ou "passar mal", Afonsinho acabou decidindo migrar para outro terreiro, no qual sua performance do bolar pode ser vivenciada da maneira que ele considera adequada, principalmente por ele estar na fase do abianato. Afonsinho parece entender esta etapa como um desenvolvimento preliminar para a feitura:

Quando começou a tocar pra Ogum, o avô de santo mandou fazer "n" coisas. Eu como desenvolvimento, né ? Como abiã, como desenvolvimento era muito importante eu tá ali na roda esperando a energia do meu orixá. [...] Eu não pude nem me concentrar, tinha que fazer tanta coisa. Mandou justamente na hora que tava cantando pro meu santo. Eu falei assim: "poxa, eu sei que a festa não é minha, mas pô, justamente essa hora que vem os orixás! (abiã Afonsinho)

A visão de Afonsinho faz todo sentido, se pensarmos a performance do bolar e do "passar mal" como etapas de treinamento e restauração de comportamento (cf. Schechner, 1988, 2011) para a performance do rum, que ele terá que executar após a feitura. Este episódio, portanto, também revela o quão importante é esta categoria de performance do bolar no processo gradual de iniciação de um fiel no candomblé.

Se prestarmos atenção na fala de Afonsinho, veremos que para ele, a qualidade de sua experiência de transe neste momento que vêm os orixás, não deixa a dever em nada para a performance do estado de santo daqueles fiéis já iniciados. Afinal, a liminaridade é a mesma, seja bolando e "passando mal" ou performando o rum. Aliás, esta é uma das grandes polêmicas entre o povo-desanto, pois muitos adeptos do candomblé defendem o posicionamento de que o abiã não vira no santo, já que não tem santo feito. Consequentemente, não há 
santo nessas circunstâncias. Isto é sempre motivo de muita xoxação ${ }^{125}$ nas rodas de conversa nos dias de xirê.

Entrementes, o ponto que mais nos interessa salientar é a qualidade desta liminaridade. Se considerarmos o que Schechner nos propõe sobre a relação entre jogo e transe, veremos que o seu conceito de fluxo ${ }^{126}$ da performance aplica-se tanto para a experiência do abiã ao bolar, como para os devotos feitos durante as performances do rum. Segundo o autor, este fluxo representa o sentimento dos performers quando sua consciência do mundo exterior desaparece e eles se fundem com o que estão realizando. O processo ritual caracteriza-se então, justamente por essa entrega ao fluxo da ação:

Os jogadores em fluxo podem estar cientes de suas ações, mas não dessa própria consciência. O que eles sentem se aproxima do estado de transe e da experiência "oceânica" dos rituais. O fluxo ocorre quando o jogador se torna uno com o jogar. "A dança me dançou". [...] Em cada caso, o limite entre o self interior e a atividade executada se dissolve. (Schechner, 2012 a, p. 105)

Neste fluxo instaurado pela performance, dissolve-se a perspectiva dualista, posto que a ação e a consciência do performer se fundem. É por meio deste fluxo que os performers atuam no campo do duplo negativo (not melnot not me), pois "atores, atletas, dançarinos, xamãs, artistas, músicos [...] treinam, praticam e/ou ensaiam para, temporariamente, 'deixar a si mesmos' e ser inteiramente 'aquilo' que estejam performando. [...] Eles não são eles mesmos, nem são eles os personagens que personificam” (Schechner, 2012 a, p. 72). Basta pensarmos o caso do ator no teatro, que ao interpretar "um personagem envolvido no fluxo da performance não é ele mesmo, mas, ao mesmo tempo, ele não é e nem deixa de ser ele mesmo" (Schechner, 2011, p. 164).

Idêntico processo ocorre nas performances do bolar, em que os abiãs narram esta "mútua possessão do atuador e do papel atuado" (cf. Carlson, 2011, p. 182), exatamente da mesma maneira que nas performances do rum:

\footnotetext{
${ }^{125}$ Xoxação: expressão bastante difundida entre o povo-de-santo para indicar uma crítica ferrenha, que desqualifica e deslegitima as performances rituais dos pares. Xoxar alguém no candomblé é retirar simbolicamente seu prestígio e veracidade. Portanto, "fazer xoxação ou xoxar poderia então ser traduzido por 'secar', 'enfraquecer o outro' e, nesse contexto, 'torná-lo sem axé"' (Opipari, 2009, p. 128). Ver também Amaral (2002, p. 39).

${ }^{126} \mathrm{Na}$ verdade, Schechner (2012 a) confere a origem do uso do termo nos estudos sobre jogos ao psicólogo americano Mihaly Csikszentmihalyi na década de 1970. Flow: a sensação de perder-se na ação, de modo que toda consciência, de qualquer coisa, à exceção de executar a ação, desaparece. Ver: Schechner (2011; 2012 a).
} 
Você sente o teu orixá mais forte. Eu senti minha mãe chegando mais perto, mais perto. Porque tem gente que fala que o abiã não vira completamente. Não sei se é verdade, se é mentira. Mas eu sempre senti minha mãe próxima. E no dia que eu bolei pela primeira vez, eu senti como se ela tivesse me dando um abraço bem forte! [...] Eu não cunseguia vê nada. Escutava o toque, escutava tudo, escutava os ôtro saudando o santo, mas eu não via nada. Depois eu não lembrava do que tinha acontecido. (abiã Caterine)

Ah, é horrível porque você não tem controle sobre o seu corpo. Você qué falá, qué se mexê e você não consegue. Tem horas que você não lembra mais de nada, que você desacorda. Daqui a pouco você volta. Não sei... a sensação daqueles filmes que a alma sai do corpo. Fica do lado de fora vendo você e você não consegue fazê nada. A sensação é bem assim. (abiã Paula)

Eu senti tremores nos pés, calafrio, meu coração palpitando. Meu coração parecia que ia sair pela aboca. Aí foi quando eu não vi mais nada. Porque eu entrei em transição, né? O orixá foi e virou na minha cabeça. Oxum virou na minha cabeça. Já não vi mais nada. (abiã Odete)

É uma sensação estranha que a gente tem, entendeu? Quando vê a gente já tá já... quando eu me sentia mal, eu pedia pra a minha orixá prá ela não me derrubar, entendeu? Aí a minha irmã disse que eu ia, ia, ia caindo de vagar, aí até que ficava caída no chão. (abiã Regina)

A relevância da performance do bolar é tanta, que ela parece funcionar também como um critério classificador das modalidades de transe dos devotos no panorama das religiões de matrizes africanas. É possível perceber nos discursos do povo-de-santo uma nítida tipologia entre a performance do orixá de umbanda ou de candomblé. Ao longo das conversas com os abiãs, fui observando que em vários casos uma espécie de tipologia da performance do bolar definiu para os devotos em qual modalidade religiosa eles melhor se adequariam:

Ele me explicou que essa santa não seria da umbanda. Seria do candomblé. Que ela vem de uma maneira diferente. Que mais tarde eu teria que me iniciar no candomblé. Porque tem diferença do orixá na umbanda e no candomblé. Na umbanda ele vem de olhos abertos, a Oxum vem chorando. No candomblé não... não chora a Oxum. (abiã Odete)

Lá era só umbanda e eu queria frequentar candomblé, porque meu orixá é de candomblé! (abiã Afonsinho)

O orixá de umbanda ele é um espírito, que vem no vento. Já de candomblé, já é um orixá criado. Os orixás de umbanda eles vêm, ele sabe o canto, ele sabe a dança, o toque de dança. Já tem ali tudo ali neles mesmos, né? Já que o candomblé, o santo é criado. Ele nasce, né? E vai ser criado. E forte né? Uma pessoa não aguenta ele completo no corpo. Porque se ele vem completo, ele derruba no chão. (abiã Janete) 
[a energia do orixá] é bem diferente da umbanda [...] Mas é uma coisa bem suave. Tirando a parte do bolar. (abiã Paula)

Aquelas pessoas se sacudindo demais. Sei lá, sabe? Tem coisas assim. Eu respeito muito a umbanda. Mas eu não iria pra ela por conta dessas coisas. Quando eu vi Ogum beber e fumar, eu fiquei meio cabreira, sabe? [...] Eu já vi pessoas virando de santo na rua sendo abiã. Na rua! [...] Já vi tanta besteira. Já vi Ogum sair de cocar e arco e flecha! (abiã Patrícia)

Sobre esse assunto, as opiniões não parecem unânimes entre os religiosos. Alguns sacerdotes, como o pai-de-santo Carlito, por exemplo, creditam esta diferença performática a uma adequação artificial elaborada pelos próprios religiosos, já que para ele em "essência” não haveria por si só uma distinção genuína entre orixás de umbanda ou de candomblé:

Hoje eu escuto muito as pessoas falarem que as pessoas buscam o candomblé porque se fala assim: "Ah, você tem santo de candomblé! Ah, porque você tem entidade de candomblé! Eu discordo completamente, porque as escolhas quem fazemos somos nós. A energia orixá ela é neutra. [...] Eles estão dizendo que existem dois tipos de orixá. E na verdade, isso não existe! A energia orixá é uma só. A energia do orixá é a energia da natureza. Quando nós materializamos essas energias é que nós damos formas a elas, na umbanda ou no candomblé. Não existe essa coisa "ah você tem santo de umbanda ou santo de candomblée" Não! Você tem orixá! Você tem santo! (pai-de-santo Carlito)

Contudo, no âmago dessas modalidades de práticas performáticas nas religiões afro-brasileiras, reside o elemento primordial da crença desses fiéis: o axé, ou seja, a força dinamizadora da existência. Como define Juana Elbein dos Santos (2002), o axé é "força que assegura a existência dinâmica, que permite o acontecer e o devir. Sem axé, a existência estaria paralisada, desprovida de toda possibilidade de realização. É o princípio que torna possível o processo vital" (Santos, 2002, p. 39). Sendo assim, os terreiros não definem-se apenas por sua territorialidade física, "mas enquanto centro de atividades litúrgicas e polo irradiador de força" (Sodré, 1988, p. 96). Em todas as etapas da vida no santo, a preocupação com o axé ressurge reafirmando a centralidade desta noção para a prática do candomblé. Posto que, o axé configura-se como o princípio básico subjacente à liturgia afro-brasileira como um todo:

Os centros de culto das religiões de matriz africana no Brasil poderiam perfeitamente ser compreendidos como enormes máquinas destinadas à capacitação, à distribuição e à circulação da força única que, em suas cosmologias, constitui tudo o que existe e pode existir no universo. [...] essa força - o axé, dos candomblés ketu, ngunzo, dos angola, ou simplesmente força, energia, em inúmeras outras religiões deste tipo - "constitui tudo o que existe e pode existir no universo, seguindo um processo de diferenciação e individuação", 
sua unidade garantindo "que tudo participa de tudo" e suas modulações fazendo

"com que haja graus de participação". (Goldman, 2012, p. 279)

Acreditando que os orixás possam ser os grandes propagadores dessa força, estar com eles durante o xirê é uma oportunidade única de mergulhar numa fonte incomensurável deste axé. Presenciar a performance do rum nas festas rituais, é partilhar diretamente do axé que os orixás podem transmitir aos homens. Com frequência, os devotos que executam as performances do rum interagem de inúmeras formas com a audiência. Todos querem um abraço, um beijo, uma insígnia ou pedaços das vestes rituais das divindades, como uma maneira de ter consigo um pouco mais do axé. Nesta ocasião, percebemos a plasticidade deste axé, que opera tal qual na noção de mana entre os melanésios:

O "mana" não é simplesmente uma força, um ser, é também uma ação, uma qualidade e um estado. Em outros termos, a palavra é ao mesmo tempo um substantivo, um adjetivo, um verbo. [...] Ele é sucessivamente e ao mesmo tempo qualidade, substância e atividade. (Mauss, 2003, p.142-143)

E, nessa efervescência ritual das performances do xirê, há os que são intensamente "tocados" por esse axé e bolam. Poderíamos também ver a atividade do bolar como a erupção deste mana que precisa ser manipulado de maneira adequada por aqueles que sejam especialistas autorizados. Da mesma forma que o mana, o axé é manejável e também independente, "eis porque só pode ser manejado por indivíduos com mana, num ato mana, isto é, por indivíduos qualificados e num rito" (Mauss, 2003, p. 143).

Dito isto, fica clara a profunda relevância simbólica do ato de bolar, tanto para o abiã, quanto para o contexto ritual. Por isso, imediatamente ao seu acontecimento, os peritos na manipulação do axé correm para executar a etiqueta ritual apropriada para a ocasião, tirando de risco o devoto envolvido e a própria estrutura geral do ebé. Como citado em passagem anterior, o abiã bolado será todo coberto com um pano branco e alçado do chão por um grupo de iniciados, que realizam um transporte cerimonial dentro do espaço sagrado. Nesta praxe ritual é de grande simbolismo este período em que o abiã não pode tocar o chão do barracão:

O mais simples, acredito, é considerar estes ritos como ritos de margem. Para mostrar que nesse momento o indivíduo não pertence nem ao mundo sagrado nem ao mundo profano, ou ainda que, pertencendo a um dos dois, não se deseja que se reagregue fora de propósito ao outro, é isolado e mantido em uma posição intermediária, sendo sustentado entre o céu e a terra, do mesmo modo que o 
morto em seu jirau de vime ou no ataúde provisório, etc., está suspenso entre a vida e a morte verdadeira. (Gennep, 2011, p. 157)

Ao participar das performances do xirê no decurso do abianato, o abiã é introduzido numa nova forma de compreender a própria corporalidade. Da mesma

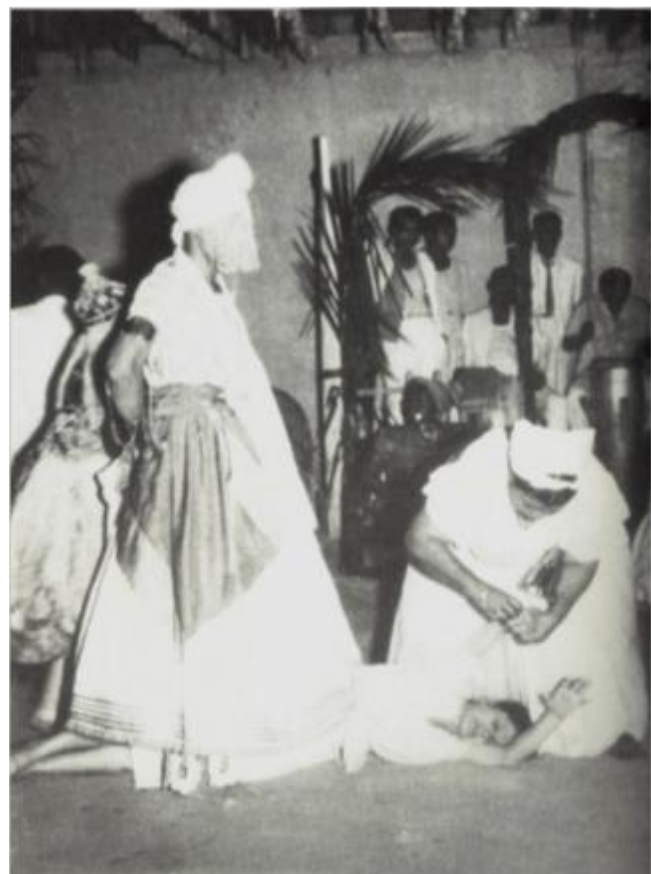

Figura 50: Devota "bolada" durante o xirê Fonte: Bastide (2001, p. 192) maneira que Dos Anjos (2001) percebe a "ida ao chão" nos rituais do Batuque, poderíamos dizer que a queda no chão sofrida pelo abiã que bola, também revela um "corpo que está sendo compreendido de forma diferente dos termos ocidentais" (Dos Anjos, 2001, p. 141), já que este corpo se modifica na queda. Pois ao bolar, o abiã "se percebe como alguém que tem um orixá materialmente presente em sua cabeça" (Dos Anjos, 2001, p. 141), mesmo que em estado ainda bruto.

Quando o abiã bola, podemos dizer que inicia ali um aflorar do orixá que se completará no rito de feitura. Não podemos jamais perder de vista, a forte simbologia do chão nas religiões de matrizes africanas. Será no mesmo chão que o abiã permanecerá ao longo da reclusão ritual da feitura. Na cosmovisão dos religiosos do candomblé, a força do orixá, "brota" do chão, fluindo pelo corpo e atingindo na cabeça o seu polo de singularização como o orixá do iniciado. Com isso, cair bolado no chão do barracão é ser apresentado desde o abianato a uma nova lógica sobre a relação, não apenas com o próprio corpo, mas, sobretudo, com o espaço do terreiro:

Muitas atividades desenvolvidas no terreiro requerem pés descalços em contato com o chão (é assim durante os sacrifícios, a limpeza dos assentamentos e a entrada no roncó). Em boa parte dos passos de dança no xirê, os pés se arrastam ao invés de se erguer bruscamente do chão. E uma vez que tomaram banho e trocaram suas roupas da rua pelos trajes brancos do candomblé, os recémchegados ao terreiro dirigem-se para um ponto central do barracão [...] e dobram seus corpos - iaôs batem a cabeça no chão, deitados; equedes e ebomis tocam os dedos da mão direita no chão, levando-os em seguida à cabeça. Sempre que se toca para um novo orixá durante o xirê, este gesto é refeito. O chão demanda respeito e reverência, é centro e fonte de axé. (Rabelo, 2014, p. 259-260) 
Diríamos que o bolar já anuncia uma aproximação mais estreita do indivíduo em relação a esta força e, portanto, a um gradiente de axé no qual o abiã avança paulatinamente, mesmo antes da feitura. Além do que, o fato de ter bolado já expõe publicamente um sinal de diferenciação deste devoto em relação a todos os que ainda não viveram esta experiência. Por isso, o recolhimento do indivíduo bolado no salão é altamente ritualizado diante do grupo. O bolar numa microanálise é também um rito de passagem em escala reduzida, e por isso, um pequeno ato de instituição, que diferencia o abiã daqueles que testemunham seu avançar na linha que separa meros visitantes de devotos efetivos do culto:

En marquant solennellement le passage d'une ligne qui instaure une division fondamentale de l'ordre social, le rite attire l'attention de l'observateur vers le passage (d'où l'expression rite de passage), alors que l'important est la ligne. Cette ligne, en effet, que sépare-t-elle? Un avant et un après [...] L'effet majeur du rite est celui qui passe le plus complètement inaperçu: en traitant différemment [...] le rites consacre la différrence. (Bourdieu, 1982, p. 58)

Ao avançar esta linha diferenciadora, a performance do bolar produz uma inconteste marca do orixá (cf. Barros, 2004) a partir da qual a trajetória religiosa do abiã dificilmente permanece a mesma. Por este prisma, entendemos que bolar já é em algum nível fazer uma passagem, que institui esta diferença entre performers e espectadores, no caso do candomblé. Como afirma Vagner Gonçalves da Silva, "a experiência de bolar pode, no entanto, ser extremamente significativa, para o convencimento do abiã (não-iniciado) da força da vontade do seu orixá ou da necessidade de sua iniciação" (Silva, 1995, p. 124).

Esta mesma passagem simbólica durante o ritual do bolar pode ser também percebida na dimensão psicológica do abiã, pois "rituais liminares mudam permanentemente o que as pessoas são. Ocorrem transformações" (Schechner, 2012 a, p.70). De acordo com as noções de transportation e transformation propostas por Schechner, como componentes fundamentais da liminaridade engendrada pela performance, constatamos que ao bolar o abiã é tanto transportado quanto transformado. Aqui esta transformação equivale a uma experiência processual de reconfiguração identitária. Pelas declarações dos abiãs após a vivência da performance do bolar, verificamos que em suas vidas cotidianas também são notadas significativas transformações permanentes, que refletem-se em mudanças de temperamento ou no despertar da percepção de uma força existencial: 
Porque eu vou te falar que eu me tornei uma pessoa muito mais compreensiva depois que eu entrei. Porque eu era muito mais nervosa. Eu sou muito agitada, mas eu era muito nervosa. Se as pessoas olhassem pra mim na rua já era motivo de briga. [...] Não fui iniciada, mas [...] passei por um processo de mudanças. Mudei muito! (abiã Odete)

Você senti aquela energia. Uma energia que te deixa bem. Depois te deixa leve. Aquela coisa parece que limpa o teu corpo. Limpa a tua alma. É sensacional! (abiã Afonsinho)

Acabou de eu bolá. Mas eu não entendia o que era bolá. Entendeu? Depois que me explicaram. [...] Estava me fazendo bem aquilo. Eu tinha saído da minha depressão. Estava conseguindo. Tinha passado pra UERJ [...] Tava tudo indo direitinho, sabe? [...] Vi tudo caminhar muito rápido. (abiã Patrícia)

No dia que eu falei que ia sair de casa por causa de uma discussão, dia 27 de fevereiro, eu falei: "se eu tenho Ogum na minha cabeça eu não passo mais um mês dentro dessa casa". No dia 19 de setembro eu tava fechando o contrato com outro apartamento, tava mudando. (abiã Afonsinho)

Contudo, Schechner adverte que tanto os performers quanto os espectadores estão sujeitos aos fenômenos de transportation e de transformation. No caso específico das performances no candomblé este processo pode ser bastante polissêmico. Por conseguinte, quando um visitante bola durante uma festividade, isto pode ser um duplo sinal: o de que o orixá deseja feitura, mas acima de tudo, que esta seja realizada exatamente naquela comunidade litúrgica na qual o devoto bolou. Ou seja, não se bola em qualquer lugar. Este acontecimento estabelece relações da divindade com o devoto, mas também com o território-terreiro. Outra mensagem subliminar do momento do bolar, é que quando ainda não se sabe qual é o orixá pessoal do abiã - pois há casos em que isso demora a ser identificado - prestar atenção às cantigas que estão sendo entoadas durante o bolar, pode ser a revelação da identidade espiritual do novo devoto.

No entanto, o estudo da liminaridade no candomblé tem se debruçado ao longo do tempo primordialmente no que tange ao rito iniciático da feitura. Desta maneira, estes estudos acabaram por privilegiar aquilo que está no cerne da religião: o processo iniciático formal e a consequente construção da performance do transe de orixá.

De fato, no momento das festividades rituais, estas são as únicas performances autorizadas a se desenvolverem diante da audiência. As pessoas vão ao candomblé para assistir às danças dos orixás, que obviamente, são executadas 
apenas pelos fiéis feitos. Com isso, o grande interesse dos pesquisadores, e porque não dizer dos curiosos visitantes também, concentra-se no misterioso processo de elaboração ou feitura desses performers dos orixás. Assim, esta etapa da iniciação religiosa passou a ser vista como o momento exclusivo no qual a performance do rum é "fabricada".

Porém, observando mais atentamente os acontecimentos no terreiro durante os xirês, poderemos constatar que outra tipologia de performance de estado de santo ocorre através do bolar ou "passar mal" dos abiãs. E o mais importante disso tudo, seria não apenas notar esta variação dos tipos de transe, mas, sobretudo, percebê-la como uma etapa igualmente significativa no longo processo de construção ritual da pessoa feita e de sua performance de orixá.

Deste modo, a proposição do diretor teatral e antropólogo Richard Schechner, nos ajuda compreender a liminaridade que está presente não só na experiência de transe daqueles filhos-de-santo que já são feitos - a performance do rum - mas também, na experiência de transe bruto dos abiãs, ou seja, a performance do bolar ou "passar mal".

Pela observação e análise das descrições dessas experiências dos abiãs, é possível perceber que em ambas as situações de transe - a dos feitos e a dos não feitos - opera um mesmo processo de performance ritual. Neste estudo, entendemos a composição deste processo conforme proposto por Schechner (1988, 2003, 2012a, b, 2011) a respeito de suas etapas constituintes: liminaridade, transportation, transformation e duplicidade do sujeito. E, alargando ainda mais o escopo de nossa análise, poderemos compreender que esta performance do bolar - coadjuvante na cena principal do xirê - constitui uma etapa de treinamento e restauração de pedaços de comportamento para a performance do rum, que após o rito iniciático, o neófito deverá desempenhar.

Assim, um mesmo devoto tem duas experiências de liminaridade performática: a primeira no bolar durante o abianato, e a segunda, no rum, após tornar-se iaô na feitura. O que este estudo pretendeu mostrar é que ambas as performances estruturam-se num longo processo ritual, em que um verdadeiro continuum opera do abianato à feitura na "carreira" religiosa do fiel. Visto por este prisma, a experiência do abianato revela-se sim como uma etapa ritual, com toda sua riqueza e complexidade, sem estar estanque do rito de passagem da feitura. 
Desta maneira, entrando com os pés desnudos no labirinto enigmático do abianato, de passo em passo vacilante e expectante, um devoto constrói sua história como candomblecista. Como a abiã Vanise me ensinou, o sentir-se candomblecista não está atrelado unicamente à experiência da feitura.

Enfim, termino relembrando as últimas palavras desta abia na sua despedida do abianato horas antes da reclusão ritual para a feitura do santo:

O simples fato de varrer o barracão, ajudar numa limpeza também é ser abiã. Eu aprendi muito! E eu me entendi como candomblecista sendo abiã. [...] Sempre foi um desejo meu ser iniciada, mas nunca quis ultrapassar. É muito da minha essência, não é uma vontade por vontade. Aquilo me toca. As cantigas me tocam, o toque do aguidavi ${ }^{127}$ no tambor. Me emociona muito a religião candomblé em si. [...] Mas eu nunca via o meu momento chegar. De ser "coroada" pela religião! Esse momento agora é só meu! (abiã Vanise)

127 Aguidavis: varetas rituais feitas do galho de algumas árvores, como a goiabeira por exemplo. Nas festividades do candomblé de modalidade Jeje-Nagô, elas são utilizadas para tocar os atabaques. 


\title{
A "feitura" do antropólogo - O cerrar das cortinas
}

\begin{abstract}
A situação de espetáculo não é pejorativa à ocorrência ritual-religiosa e sim uma maneira de situar como a festa é culminância e momento social que traz a vida ritualizada do terreiro. (Lody, 2006, p.146)
\end{abstract}

Na década de 1973, nas suas últimas incursões etnográficas nos candomblés no Brasil, Roger Bastide legou aos estudiosos do assunto uma valiosa contribuição temática, que parece não ter frutificado nas pesquisas subsequentes. Num de seus últimos escritos intitulado "As escravas dos deuses" (1973), incluído na reedição do livro "O sagrado selvagem e outros ensaios" (2006), o autor declara surpreso consigo próprio e seus pares acadêmicos, o fato de terem permanecido tanto tempo pesquisando o candomblé, sem jamais se darem conta da ostensiva presença dos abiãs no cotidiano dos terreiros. Como ele pontua ao longo do texto, essa "reserva permanente de filhas possíveis dos deuses" sempre esteve presente nas festividades dos barracões, porém "temos de confessar que durante nossos primeiros estudos de campo prestamos muito pouca atenção a essa categoria de pessoas" (Bastide, 2006, p.240-241).

Esta constatação de Bastide me parece ainda bastante valiosa para as pesquisas sobre o candomblé na atualidade. Como argumentei neste estudo, a categoria dos abiãs foi pouquíssimo explorada pela literatura especializada até então. Inclusive, há muitas incursões etnográficas a respeito da trajetória iniciática no candomblé, que sequer citam a existência deste primeiro estágio da hierarquia religiosa. De uma maneira geral, nas pesquisas sobre o candomblé ao longo das últimas décadas, os discursos dos sacerdotes e dos já iniciados, assim como suas respectivas performances no cotidiano dos terreiros foram sempre priorizados. Desta forma, a literatura socioantropológica tem retratado o abiã apenas como uma categoria satélite dentro do núcleo duro dos ritos fundamentais que constituem o candomblé. É certo que como uma religião hierárquica e de teor iniciático, passar pelos ritos de iniciação constitui condição indispensável para a construção da identidade religiosa de um candomblecista. E não há dúvidas de que o rito iniciático e a experiência do transe de orixá sejam os pilares dessa prática religiosa. 
No entanto, numa aproximação empírica mais intensa da realidade dos terreiros, logo nos apercebemos da presença marcante destes atores, que mesmo não iniciados pelo rito da feitura, participam de modo intenso do cotidiano dos templos, partilhando dos ensinamentos sobre uma forma típica de ver e de viver no mundo. Portanto, como qualquer um dos atores que atuam neste espaço social, os abiãs podem servir de excelente espelho das idiossincrasias deste grupo religioso em particular. Afinal, em muitos casos, o abianato pode ser constituído por um período de anos de intensa sociabilização nas casas de santo.

O primeiro objetivo deste estudo foi justamente destacar a presença dessa categoria de fiéis e sua forma específica de viverem o candomblé, de acordo com as restrições condicionadas pela subalterna posição hierárquica que ocupam. E, para além de salientar a existência e participação ativa desses noviços nas casas de axé, busquei primordialmente fazer com que seus próprios discursos fossem valorizados ao longo desta investigação antropológica. Na verdade, me instigou dar visibilidade na literatura especializada para aquilo que no campo já possui o seu destaque. Pois creio que a invisibilidade destes abiãs nas pesquisas seja motivada muito mais por escolhas externas ao culto. Nos seus lugares de origem, os abiãs tem sua importância reconhecida, principalmente por eles próprios, como procurei demonstrar.

Todavia, deste emaranhado de práticas e sentidos engendrados nas redes de socialização dos terreiros, foi preciso fazer algumas escolhas para concretizar esta desafiadora proposta inicial que me lancei. Sendo assim, segui as pistas oferecidas pelas narrativas de um grupo de abiãs e percebi que em todos os discursos, a intensa dimensão estética do cerimonial público do candomblé marcou sobremaneira as decisões de adesão a esta tipologia religiosa.

Como pôde ser percebido nas biografias de meus interlocutores, mesmo que algum tipo de aflição (cf. Fry, 1975) tenha os levado aos templos de candomblé, é a experiência do prazer da festa que pareceu tocá-los e, ainda como espectadores, fazê-los acreditar que seria válido aderir a esta identidade religiosa e cultural. Em cada uma das entrevistas que realizei foram apresentadas diversas pistas do quanto a "espetacularidade" desses eventos rituais exerce certo fascínio - ou como preferem os fiéis, encanto - nos seus visitantes espectadores.

Os abiãs participantes deste estudo demonstraram que, muito mais do que por uma via cognitiva, é através do aparelho sensorial que ocorre a "conversão" 
de boa parte dos devotos. Ao contrário das religiões reveladas pelo "livro sagrado", no candomblé o corpo é o texto que expressa o mistério. Como disse o pai-de-santo da abiã Caterine certa vez: "os orixás são fragmentos de nossas emoções". Por este prisma, a explosão das sensações e emoções durante o xirê pode figurar como um caminho direto ao numinoso afro-brasileiro. Sendo o próprio termo candomblé tomado como sinônimo de festa, "nesse sentido [ela] pode ser entendida como o proselitismo do candomblé" (Amaral, 2002, p. 32).

Por conseguinte, passei boa parte de meu percurso etnográfico perguntando aos meus interlocutores qual seria a importância do corpo no candomblé. Ainda confuso na minha liminaridade de antropólogo em processo de feitura, tentei de múltiplas maneiras reformular esta pergunta que praticamente todos eles tiveram dificuldade de responder, quando elaborada exatamente desta forma. Foram incontáveis as vezes que ouvi: “como assim? não entendi essa pergunta?". Somente depois de um bom tempo desisti de fazê-la, não porque acreditei na impossibilidade dos abiãs de respondê-la, mas pela minha incipiente habilidade antropológica de perceber que ela já havia sido respondida logo nos primeiros minutos de cada conversa. Quiçá, ao longo de todas as entrevistas!

Ao iniciarem suas narrativas relembrando seus primeiros passos até o candomblé, rapidamente apareciam as reminiscências de alguma festa na qual os devotos teriam sentido pela primeira vez o prazer de ser tomado pela "onda oceânica" (cf. Schechner, 2012a, p.105) das performances rituais. Revisitando todas as biografias desses abiãs em meio as infindáveis horas de gravação e escarafunchando na memória as incontáveis cenas que presenciei nos ritos do candomblé nos últimos anos, compreendi também a grande importância de refletir sobre a experiência festiva do xirê como exercício da fé e do prazer estético simultaneamente. As trajetórias dos abiãs me convenceram da necessidade de prestar mais atenção neste aspecto.

No bojo das festas cerimoniais, é justamente através do corpo que os espectadores e performers se sentem unos, durante as performances dos filhos-desanto. E, segundo me relataram os abiãs deste estudo, a maioria dos novos adeptos é guiada pelo prazer desta sensação até o ingresso no abianato, o que pode estar aliado ou não a algum tipo de aflição (cf. Fry 1975). Durante a realização do xirê vemos operar o caráter integrador das performances rituais (cf. Schechner, 2012a), que revelam a existência de uma intensa dialética entre 
eficácia religiosa e entretenimento, pois:

O fato é que em qualquer período histórico, em qualquer parte do mundo e em toda cultura, as pessoas fizeram e fazem danças, música e teatro. As performances possuem várias finalidades, incluindo entretenimento, ritual, construção de uma comunidade e socialização. Essas funções podem ser resumidas como a tensão dinâmica entre a eficácia e o entretenimento. [...] O movimento da performance estética para o ritual acontece quando um público formado por indivíduos se transforma em uma comunidade. (Schechner, 2012a, p. 83)

Por esta razão, também procurei dar destaque à dimensão "espetacular" das cerimônias públicas do candomblé, não apenas por sintetizar o ethos do povode-santo (cf. Amaral, 2002; 1998), mas, sobretudo, por perceber sua influência sobre os espectadores que tornam-se abiãs. Além do que, os "espetáculos" dos orixás constituírem um manancial de ensinamentos sobre a maneira de ser candomblecista. Por isso, percebi com maior clareza o real continuum entre a festa ritual do candomblé e o teatro:

A festa de candomblé, por suas características intrínsecas de ludismo, através do canto e da dança, de ultrapassamento do "eu", no transe, de um figurino e papeis previamente conhecidos por todos os que dela participam, assume características de um drama ritual, semelhante ao drama teatral, onde são vividas as histórias dos deuses e a dos homens do povo-de-santo. É o tipo de festa que Duvignaud chama de festa de participação. (Amaral, 1998, p. 106)

Entretanto, passei a pensar sobre as performances dos abiãs pela perspectiva teatral proposta por Richard Schechner. Como diretor de teatro e antropólogo, ele delineou uma abordagem a respeito da performance bastante abrangente, de forma que a compreensão de suas propriedades intrínsecas suplantasse a clássica separação entre eventos estéticos (teatro, dança etc.) e práticas rituais (ritos de passagem, xamanismo etc.). Na visão de Schechner, "qualquer comportamento, evento, ação, ou coisa pode ser estudado como se fosse performance e analisado em termo de ação, comportamento, exibição" (Schechner, 2003, p.29). Sendo assim, utilizei este prisma para refletir sobre os papeis desempenhados pelos religiosos nas casas de axé, pois por mais espontâneas que possam parecer suas atuações neste contexto, elas estão sempre estruturadas sobre modelos fornecidos pelo ethos do grupo:

Performances - sejam elas performances artísticas, esportivas ou a vida diária consistem na ritualização de sons e gestos. Mesmo quando pensamos que estamos sendo espontâneos e originais, a maior parte do que fazemos e falamos já foi feita e dita antes - "até mesmo por nós". [...] Performances consistem de comportamento duplamente exercidos, codificados e transmissíveis. (Schechner, 2012a, p. 49) 
Então, proponho que é no abianato, e não exclusivamente no rito de passagem da feitura, que começam os primeiros aprendizados e treinamentos (cf. Schechner, 1988; 2012a; 2012b) das técnicas corporais (cf. Mauss, 2003) que informam as performances de um efetivo candomblecista. Na minha concepção, essa primeira fase da "carreira" religiosa do fiel não deveria ser resumida apenas como um período de mera familiarização, ou seja, de simples viabilidade do estreitamento de laços sociais e rituais futuros, entre os atores envolvidos nessa realidade cultural. O lugar ocupado pelo abiã no contexto sócio-religioso de uma comunidade litúrgica específica transforma o abianato num silencioso processo preliminar de construção ritual do ser candomblecista. Nesta ocasião especial na qual os abiãs se enquadram durante certa temporalidade, são forjadas paulatinas adaptações aos seus modos de agir visando sua adequação ao ethos do grupo religioso. É Marcel Mauss quem nos esclarece em relação a esse processo típico de instrumentalização da corporalidade nas culturas:

Essa adaptação constante a um objetivo físico, mecânico, químico (por exemplo, quando bebemos) é efetuada numa série de atos montados, e montados no indivíduo não simplesmente por ele próprio mas por toda a sua educação, por toda a sociedade da qual faz parte, conforme o lugar que nela ocupa. (Mauss, 2003, p. 408)

Portanto, argumento que o abianato seja apreendido como uma fase crucial de restauração de pedaços de comportamento para que após a feitura o religioso possa desempenhar sua performance como membro efetivo do candomblé. Além do que, alerto para o fato de que - na contramão do discurso hegemônico - o devoto durante o ritual da feitura não ocupa o "ponto zero" do longo processo de construção ritual da pessoa no candomblé. Não obstante a reclusão ritual represente o paroxismo dessa transição identitária de status, é durante o abianato vivido anteriormente à feitura que ocorrem os primeiros movimentos nesse sentido. Nos meses ou anos de abianato, a observação e interação nos rituais constituem verdadeiros ensaios e treinamentos para a performance do rum de orixá, que somente após a feitura este religioso estará autorizado a executar.

Seguindo essas assertivas de Schechner analisei a liminaridade vivida pelos abiãs na performance de bolar ou "passar mal" como sendo fundamental para a constituição ritual da identidade de candomblecista. Pelos transportes e transformações permanentes (cf. Schechner, 2012a) sofridas pelos abiãs nessas 
performances, identifiquei o continuum que liga o abianato à feitura. Para nos apropriarmos da metáfora corporal tão explorada ao longo deste estudo, dos pés vacilantes nos aprendizados do abianato à cabeça sacralizada no rito da feitura, sugiro que todas as etapas hierárquicas do candomblé sejam vistas como um corpo unificado do processo ritual iniciático.

Enfim, busquei demonstrar que o abiã e a experiência do abianato constituem uma participação ritual de grande relevância simbólica e identitária na "carreira" religiosa dos candomblecistas. Porém, consciente da impossibilidade de esgotar este objeto de investigação, apenas no curto fôlego de uma pesquisa de mestrado, lanço minha contribuição para futuras incursões antropológicas, minhas e de outros colegas de ofício. Há ainda um infindável material humano a ser apreendido na rica vivência dos abiãs no dia a dia dos barracões de candomblé. Se usarmos esta lente tão pouco escolhida para interpretar a trama diversificada e complexa da realidade cultural do povo-de-santo, muito poderemos compreender sobre o "espetáculo" dos orixás.

Encerro meu "abianato antropológico", com a certeza de que a liminaridade que vivi neste percurso etnográfico me transformou sobremaneira e contribuiu para os estudos sobre o candomblé. 


\section{Referências bibliográficas}

ABIMBOLA, Wande. A concepção iorubá da personalidade humana. In: Colóquio Internacional para A Noção de Pessoa na África Negra, Paris, 1971. Centre National de la Recherche Scientifique, Ed. nº 544. Paris, 1981

AMARAL, Rita. Awon xirê! A festa de candomblé como elemento estruturante da religião. In: MOURA, Carlos Eugênio Marcondes de. (Org.) Leopardo dos olhos de fogo: escritos sobre a religião dos orixás VI. São Paulo: Ateliê Editorial, 1998.

- Xirê! O modo de crer e de viver no candomblé. Rio de Janeiro: Pallas; São Paulo: EDUC, 2002.

ARTAUD, Antonin. O teatro e seu duplo. 3.ed. São Paulo: Martins Fontes, 2006.

AUGRAS, Monique. O duplo e a metamorfose: a identidade mítica em comunidades nagô. 2a . ed. Petrópolis, Rio de Janeiro: Vozes, 2008.

BAPTISTA, José Renato de Carvalho. Os deuses vendem quando dão: os sentidos do dinheiro nas relações de troca no candomblé. Mana, 13 (1): 7-40, 2007.

BARROS, José Flávio Pessoa de. O banquete do rei - olubajé: uma introdução à música sacra afro-brasileira. 2.ed. Rio de Janeiro: Pallas, 2005.

BARROS, José Flávio Pessoa de; TEIXEIRA, Maria Lina Leão. O código do corpo: inscrições e marcas dos orixás. In: MOURA, Carlos Eugênio Marcondes de (Org.). Candomblé: religião do corpo e da alma: tipos psicológicos nas religiões afro-brasileiras. Rio de Janeiro: Pallas, 2000.

BASTIDE, Roger. As religiões africanas no Brasil: contribuição a uma sociologia das interpenetrações das civilizações. Vol. I e II. São Paulo: Livraria Pioneira Editora: Editora da Universidade de São Paulo, 1971.

. Estudos afro-brasileiros. Perspectiva: São Paulo, 1973.

Paulo, 2001.

O candomblé da Bahia: rito nagô. 2. Ed. Companhia das Letras: São 2006.

O sagrado selvagem e outros ensaios. São Paulo: Companhia das Letras,

BENISTE, José. As águas de oxalá: àwon omi Ósàlá. 4. ed. Rio de Janeiro: Bertrand Brasil, 2006.

ÒRUN - Àiyé: o encontro de dois mundos: o sistema de relacionamento nagô-yorubá entre o céu e a Terra. 12. ed. Rio de Janeiro: Bertrand Brasil, 2015.

BIRMAN, Patrícia. O que é umbanda? São Paulo: Abril Cultural: Brasiliense, 
1985.

BOURDIEU, Pierre. Les rites comme actes d'institution. Actes de la recherche em sciences sociales. Vol.43, juin 1982. Rites et fétiches, pp.58-63.

BRAGA, Julio. O jogo de búzios: um estudo da adivinhação no candomblé. Editora Brasiliense: São Paulo, 1988.

A cadeira de ogã e outros ensaios. Rio de Janeiro: Pallas, 2009.

CACCIATORE, Olga Gudolle. Dicionário de cultos afro-brasileiros: com origem das palavras. Rio de Janeiro: Forense Universitária, 1977.

CARLSON, Marvin. O entrelaçamento dos estudos modernos da performance e as correntes atuais em antropologia. Revista Brasileira de Estudos da Presença, Porto Alegre, v.1, n.1, p.164-188, jan./jun. 2011. Disponível em $\langle\underline{\text { http://www.ufrgs.br/presença }>}$

CARNEIRO, Edison. Religiões negras e negros bantos. 3. ed. Rio de Janeiro: Civilização Brasileira, 1991.

Candomblés da Bahia. 9. ed. São Paulo: Editora WMF Martins Fontes, 2008 .

CASTILLO, Lisa Earl. Entre a oralidade e a escrita: a etnografia nos candomblés da Bahia. Salvador: EDUFBA, 2010.

CONTINS, Marcia. O caso da Pomba-Gira: reflexões sobre crime, possessão e imagem feminina. In: GOMES, Edlaine (Org.). Dinâmicas contemporâneas do fenômeno religioso na sociedade brasileira. São Paulo: Ideias e Letras, 2009.

Ritual e performance no espaço urbano: o caso das religiões afrobrasileiras. In: CONTINS, Marcia; LOPES, Vânia Penha; ROCHA, Carmem Silva Moretzsohn. (Orgs.). Religiosidade e performance. Rio de janeiro: Mauad X: FAPERJ, 2015.

As religiões afro-brasileiras e a cidade. Z Cultural: Revista do Programa Avançado de Cultura Contemporânea, 2016. Disponível em: http: // revistazcultural.pacc.ufrj.br/as-religioes-afro-brasileiras-e-a-cidade

COSSARD, Gisèle Omindarewá. A filha-de-santo. In: MOURA, Carlos Eugênio Marcondes de (org.). Olóòrìsà: escritos sobre a religião dos orixás. São Paulo: Ágora, 1981.

Awó: o mistério dos orixás. Rio de Janeiro: Pallas, 2006.

DAMATTA, Roberto. O ofício de etnólogo, ou como ter "anthropological blues". In: NUNES, Edson de Oliveira (Org.). A aventura sociológica: objetividade, paixão, improviso e método na pesquisa social. Rio de Janeiro: Zahar Editores, 1978.

A casa \& a rua. 5. ed. Rio de Janeiro: Rocco, 1997. 
DOS ANJOS, José Carlos Gomes. O corpo nos rituais de iniciação do batuque. In: LEAL, Ondina Fachel. Corpo e significado: ensaios de antropologia social. 2. ed. Porto Alegre: Editora da Universidade UFRGS, 2001

DOUGLAS, Mary. Pureza e perigo. 2. ed. São Paulo: Perspectiva, 2014.

DUCCINI, Luciana. Diplomas e decás: identificação religiosa de membros de classe média no candomblé. Salvador: EDUFBA, 2016.

EVANGELISTA, Daniele Ferreira. Emoção não é coisa de equede: mudanças de status e relações de poder no candomblé. Revista Intratextos. vol. 4, n. 1, p. 93106,2013

"Dando satisfação" aos espíritos de umbanda: "desenvolvimento" e possessão num terreiro de candomblé. In: CONTINS, Marcia; LOPES, Vânia Penha; ROCHA, Carmem Silvia Moretzsohn (Orgs.). Religiosidade e performance: diálogos contemporâneos. Rio de Janeiro: Mauad X: FAPERJ, 2015.

EVANS-PRITCHAD, Edward Evan. A dança. In: CAVALCANTI, Maria Laura. (Org.) Ritual e performance: 4 estudos clássicos. Rio de Janeiro: 7 Letras, 2014.

FONSECA, Denise Pini Rosalem; GIACOMINI, Sonia Maria (Orgs.). Presença do axé: mapeando terreiros no Rio de Janeiro. Rio de Janeiro: Ed. PUC-Rio, 2013.

FORTES, Meyer. Festivais rituais e coesão social no interior da Costa do ouro. In: CAVALCANTI, Maria Laura. (Org.) Ritual e performance: 4 estudos clássicos. Rio de Janeiro: 7 Letras, 2014.

FOUCAULT, Michel. Microfísica do poder. 25. ed. São Paulo: Graal, 2012.

FRY, Peter; HOWE, Gary Nigel. Duas respostas à aflição: umbanda pentecostalismo. Debate e Crítica. São Paulo: HUCITEC, n.6, jul., p.75-94,1975.

GEERTZ, Clifford. Nova luz sobre a antropologia. Rio de Janeiro: Zahar, 2001.

. A interpretação das culturas. Rio de Janeiro: LTC, 2013.

GENNEP, Arnold Van. Os ritos de passagem: estudo sistemático dos ritos da porta e da soleira, da hospitalidade, da adoção, gravidez e parto, nascimento, infância, puberdade, iniciação, ordenação, coroação, noivado, casamento, funerais, estações, etc. 3. ed. Petrópolis: Vozes, 2011.

GOLDMAN, Marcio. A construção ritual da pessoa: a possessão no candomblé. In: MOURA, Carlos Eugênio Marcondes de. (Org.) Candomblé: desvendando identidades. São Paulo: EMW Editores, 1987.

O dom e a iniciação revisitados: o dado e o feito em religiões de matriz africana no Brasil. Mana, 18 (2), 269-288, 2012.

HERSKOVITS, Melville J. Pesquisas etnológicas na Bahia. Salvador: Secretaria 
de Educação e Saúde, 1943.

JAGUN, Márcio de. Orí: a cabeça como divindade. História, cultura, filosofia e religiosidade africana. Rio de Janeiro: Litteris, 2015.

LANDES, Ruth. A cidade das mulheres. 2. ed. UFRJ: Rio de Janeiro, 2002.

LANGDON, Esther Jean. Performance e preocupações pós-modernas na antropologia. In: TEIXIERA, João Gabriel L. C. Performáticos, performance e sociedade. Brasília: Editora da Universidade de Brasília, 1996.

LARROSA, Jorge. Linguagem e educação depois de Babel. Belo Horizonte: Editora Autêntica, 2004.

LE BRETON, David. As paixões ordinárias: antropologia das emoções. Petrópolis: Rio de Janeiro: Editora Vozes, 2009.

A sociologia do corpo. 6. ed. Petrópolis: Rio de Janeiro: Vozes, 2012.

Adeus ao corpo: antropologia e sociedade. 6. ed. Campinas: São Paulo: Papirus, 2013.

LEITE, Fábio Rubens da Rocha. A questão ancestral: África negra. São Paulo: Palas Athena: Casa das Áfricas, 2008.

LÉPINE, Claude. Os estereótipos da personalidade no candomblé nagô. In: MOURA, Carlos Eugênio Marcondes de. (Org.) Candomblé: religião do corpo e da alma: tipos psicológicos nas religiões afro-brasileiras. Rio de Janeiro: Pallas, 2000 .

O candomblé africanizado no campo religioso de São Paulo: um balanço. In: NEGRÃO, Lísias Nogueira. (Org.). Novas tramas do sagrado: trajetórias e multiplicidades. São Paulo: EDUSP: FAPESP, 2009.

LIGIÉRO, José Luiz. Iniciação ao candomblé. 9. ed. Rio de Janeiro: Nova Era, 2006.

Garamond, 2011.

Corpo a corpo: estudo das performances brasileiras. Rio de Janeiro:

LIMA, Vivaldo da Costa. A família de santo nos candomblés jejes-nagôs da Bahia: um estudo de relações intragrupais. 2. ed. Salvador: Corrupio, 2003.

Lessé Orixá: nos pés do santo. Salvador: Corrupio, 2010.

Organização do grupo de candomblé. Estratificação, senioridade e hierarquia. In: MOURA, Carlos Eugênio Marcondes de. (Org.) Culto aos orixás: voduns e ancestrais nas religiões afro-brasileiras. Rio de Janeiro: Pallas, 2011.

LODY, Raul. Tem dendê, tem axé: uma etnografia do dendezeiro. Rio de Janeiro: Pallas, 1992. 
Jóias de axé: fios-de-contas e outros adornos do corpo: A joalheria afrobrasileira. Bertrand Brasil: Rio de Janeiro, 2001.

Pallas, 2003.

Dicionário de arte sacra \& técnicas afro-brasileiras. Rio de Janeiro:

O povo de santo: religião, história e cultura dos orixás, voduns, inquices e caboclos. 2. ed. São Paulo: WMF Martins Fontes, 2006.

Xirê: divertimento, espaço das danças, espaço de revelação do sagrado. In: GUIMARÃES, Roberta. O sagrado, a pessoa e o orixá. Recife: Imago Fotografia, 2013 a

A fala corporal. In: GUIMARÃES, Roberta. O sagrado, a pessoa e o orixá. Recife: Imago Fotografia, 2013b

LODY, Raul; SILVA, Vagner Gonçalves da. Joãozinho da Goméia: o lúdico e o sagrado na exaltação do candomblé. In: Silva, Vagner Gonçalves da (Org.). Caminhos da alma: memória afro-brasileira. São Paulo: Summus, 2002.

MAGGIE, Yvonne. Guerra de Orixá: um estudo de ritual e conflito. Rio de Janeiro: Zahar Editores, 1975.

Medo do feitiço: relações entre magia e poder no Brasil. Rio de Janeiro: Arquivo Nacional, 1992.

MAGGIE, Yvonne; CONTINS, Marcia. Gueto cultural ou a umbanda como modo de vida: notas sobre uma experiência de campo na Baixada Fluminense. In: VELHO, Gilberto (org.). O desafio da cidade: novas perspectivas da antropologia brasileira. Rio de Janeiro: Campus, 1980, p. 77-92.

MAGNANI, José Guilherme Cantor. Umbanda. 2. ed. São Paulo: Ática, 1991.

Quando o campo é a cidade: fazendo antropologia na metrópole. In: MAGNANI, José Guilherme Cantor \& TORRES, Lilian. Na metrópole: textos de antropologia urbana. 3. ed. São Paulo: EDUSP/ FAPESP, [1996] 2008.

Da periferia ao centro: trajetórias de pesquisa em antropologia urbana. São Paulo: Editora Terceiro Nome, 2012.

MAUSS, Marcel. Sociologia e antropologia. São Paulo: Cosac Naify, 2003.

Noções de técnicas do corpo. In: BARBA, Eugenio; SAVARESE, Nicola.

(Org.) A arte secreta do ator: um dicionário de antropologia teatral. São Paulo: É Realizações, 2012.

Ensaio sobre a dádiva: forma e razão da troca nas sociedades arcaicas. São Paulo: Cosac Naify, 2013.

MEDEIROS, José. Candomblé. São Paulo: Instituto Moreira Salles, 2009. 
MENDES, Andrea. O rei do candomblé nas páginas da revista: Joãozinho da Goméia em $O$ Cruzeiro (1967). Recôncavo: Revista de História da UNIABEU, vol.4, n.6, janeiro - junho, 2014.

MILLS, C. Wright. Sobre o artesanato intelectual e outros ensaios. Rio de Janeiro: Jorge Zahar Editor, 2009.

MOREIRA, Adaílton. Celebração do nascimento iniciático no candomblé. In: LOPES, Antonio Herculano. (Org.) Religião e performance ou as performances das religiões brasileiras. Rio de Janeiro: Edições Casa de Rui Barbosa, 2007.

OLIVEIRA, Altair B. Cantando para os orixás. 4. ed. Rio de Janeiro: Pallas, 2009.

PARÉS, Luis Nicolau. A formação do Candomblé: história e ritual da nação jeje na Bahia. 2. ed. Unicamp: Campinas, 2007.

PEREIRA, João Batista Borges. A Cultura Negra: resistência de cultura à cultura de resistência. In: Dédalo, v.23, 1989. p. 177-187.

PIERSON, Donald. O candomblé da Baía. Curitiba: São Paulo: Rio de Janeiro: Editora Guaíra Limitada, 1942.

PÓVOAS, Ruy do Carmo. Dentro do quarto. In: CAROSO, Carlos; BACELAR, Jeferson. Faces da tradição afro-brasileira: religiosidade, sincretismo, antisincretismo, reafricanização, práticas terapêuticas, etnobotânica e comida. 2. ed. Rio de Janeiro: Pallas; Salvador, BA: CEAO, 2006.

PRANDI, Reginaldo. Os candomblés de São Paulo: a velha magia na metrópole nova. São Paulo: HUCITEC, 1991.

Herdeiras do axé: sociologia das religiões afro-brasileiras. São Paulo: HUCITEC, 1996.

O candomblé e o tempo. Concepções de tempo, saber e autoridade da África para as religiões afro-brasileiras. Revista Brasileira de Ciências Sociais, vol. 16 , n. 47, outubro/2001.

Segredos guardados: orixás na alma brasileira. São Paulo: Companhia das Letras, 2005.

QUERINO, Manuel. Costumes africanos no Brasil. 2. ed. Salvador: EDUNEB, 2010.

RABELO, Miriam C. M. Enredos, feituras e modos de cuidado: dimensões da vida e da convivência no candomblé. Salvador: EDFBA, 2014.

RAMOS, Arthur. O Negro na Civilização Brasileira. Rio de Janeiro. Ed. Casa do Estudante. 1971.

RAMOS, Eurico. Revendo o candomblé: respostas às mais frequentes perguntas sobre a religião. Rio de Janeiro: Mauad X, 2011. 
REIS, João José. Domingos Sodré, um sacerdote africano: escravidão, liberdade e candomblé na Bahia do século XIX. Companhia das Letras: São Paulo, 2008.

RODRIGUES, Raimundo Nina. O animismo fetichista dos negros bahianos. Rio de Janeiro: Civilização Brasileira, 1935.

Os africanos no Brasil. São Paulo: Editora Nacional, 1977.

SABINO, Jorge; LODY, Raul. Danças de matriz africana: antropologia do movimento. Rio de Janeiro: Pallas, 2011.

SANT'ANNA SOBRINHO, José. Terreiros Egúngún: um culto ancestral afrobrasileiro. Salvador: EDUFBA, 2015.

SANTOS, Juana Elbein dos; SANTOS, Deoscoredes M. dos. O culto dos ancestrais na Bahia: o culto dos Égun. In: MOURA, Carlos Eugênio Marcondes de. (Org.) Olóòrìsà: escritos sobre a religião dos orixás. São Paulo: Ágora, 1981.

SANTOS, Juana Elbein dos. Os nagô e a morte: pàde, àsèsè e o culto égun na Bahia. 11 a . ed. Petrópolis: Vozes, 2002.

SANTOS, Eufrazia Cristina Menezes. Religião e espetáculo: análise da dimensão espetacular das festas públicas do candomblé. São Paulo, 2005. 229p. Tese de Doutorado em Antropologia Social. Faculdade de Filosofia, Letras e Ciências Humanas. São Paulo, FFLCH/USP, 2005.

SANTOS, Edmar Ferreira. O poder dos candomblés: perseguição e resistência no Recôncavo da Bahia. Salvador: EDUFBA, 2009.

SCHECHNER, Richard. Performance Theory. New York and London: Routledge: 1988.

O que é performance? O percevejo. Revista de teatro, crítica e estética. Rio de Janeiro: UNIRIO. Ano 11, n.12: 25-50, 2003.

Performers e espectadores: transportados e transformados. Moringa: João Pessoa, vol. 2, n. 1, 155-185, jan./jun., 2011

LIGIÉRO, Zeca (Org.). Performance e antropologia de Richard Schechner. Rio de Janeiro: Mauad X, 2012a.

Restauração do comportamento. In: BARBA, Eugenio; SAVARESE, Nicola. (Org.) A arte secreta do ator: um dicionário de antropologia teatral. São Paulo: É Realizações, 2012b.

SEGALEN, Martine. Ritos e rituais contemporâneos. Rio de Janeiro: Editora FGV, 2002.

SILVA, Rubens Alves. Entre "artes" e "ciências": a noção de performance e drama no campo das ciências sociais. Horizontes Antropológicos: Antropologia e performance. Porto Alegre, ano 11, n.24, jul./dez. de 2005a. 
A performance congadeira na missa da sete: notas sobre manifestações de congados na Festa de Agosto no sertão de Minas Gerais. In: LOPES, Antonio Herculano. (Org.) Religião e performance ou as performances das religiões brasileiras. Rio de Janeiro: Edições Casa de Rui Barbosa, 2007.

A atualização de tradições: performances e narrativas afro-brasileiras. São Paulo: LCTE Editora, 2012.

SILVA, Vagner Gonçalves. Orixás da metrópole. Petrópolis: Vozes, 1995.

As esquinas sagradas: o candomblé e o uso religioso da cidade. In: MAGNANI, José Guilherme Cantor \& TORRES, Lilian. (Org.) Na metrópole: textos de antropologia urbana. São Paulo: EDUSP/FAPESP, 1996.

Candomblé e umbanda: caminhos da devoção brasileira. 2. ed. São Paulo: Selo Negro, 2005b.

O antropólogo e sua magia: trabalho de campo e texto etnográfico nas pesquisas antropológicas sobre religiões afro-brasileiras. São Paulo: EDUSP, 2006.

Exu: o guardião da casa do futuro. Rio de Janeiro: Pallas, 2015.

SILVA, Vagner Gonçalves; LODY, Raul. Joãozinho da Goméia: o lúdico e o sagrado na exaltação do candomblé. In: Silva, Vagner Gonçalves da. (Org.) Caminhos da alma: memória afro-brasileira. São Paulo: Summus, 2002.

SILVA, Hélio R. S. A situação etnográfica: andar e ver. Horizontes antropológicos. Porto Alegre, ano15, n. 32, p.171-188, jul./dez. 2009.

SODRÉ, Muniz. O terreiro e a cidade: a forma social negro-brasileira. Vozes: Petrópolis, 1988.

A verdade seduzida: por um conceito de cultura no Brasil. 3. ed. Rio de Janeiro: DP\&A, 2005.

SOUZA, Patrícia Ricardo de. Axós e ilequês: rito, mito e a estética do candomblé. São Paulo, 2007. 183p. Tese de doutorado. São Paulo: USP.

TRINDADE-SERRA, Ordep José. Pureza e confusão: as fontes do limbo. Anuário Antropológico, Rio de Janeiro, v. AA/79, N.OO, p. 148-167, 1981.

TURNER, Victor. The anthropology of performance. New York: PAJ Publications, 1987.

Floresta de símbolos: aspectos do ritual Ndembu. Niterói: EDUFF, 2005.

O processo ritual: estrutura e antiestrutura. 2. ed. Petrópolis: Vozes, 2013.

VERGER, Pierre Fatumbi. Orixás: deuses iorubás na África e no novo mundo. 6. ed. Salvador: Corrupio, 2002. 
Fluxo e refluxo: do tráfico de escravos entre o Golfo do Benin e a Bahia de Todos os Santos dos séculos XVII a XIX. 4ª . ed. rev. Salvador: Corrupio, 2012.

Notas sobre o culto aos orixás e voduns na Bahia de todos os santos, no Brasil, e na antiga Costa dos escravos, na África. 2. ed. São Paulo: EDUSP, 2012.

VOGEL, Arno; MELlO, M. A. da Silva; BARROS, J. F. Pessoa de. Galinha d'angola: iniciação e identidade na cultura afro-brasileira. 3. ed. Rio de Janeiro: Pallas, 2005.

ZENÍCOLA, Denise Mancebo. A coreografia das iabás. O percevejo. Revista de teatro, crítica e estética. Rio de Janeiro: UNIRIO. Ano 11, n.12: 25-50, 2003

A dança das iabás: performance e ritual. In: LOPES, Antonio Herculano. (Org.) Religião e performance ou as performances das religiões brasileiras. Rio de Janeiro: Edições Casa de Rui Barbosa, 2007.

Performance e ritual: a dança das iabás no xirê. Rio de Janeiro: Mauad X: FAPERJ, 2014

ZIEGLER, Jean. Os vivos e a morte: uma sociologia da morte no ocidente e na diáspora africana no Brasil e seus mecanismos culturais. Rio de Janeiro: Zahar Editores, 1977. 